\title{
PROTEROZOIC PALEOWEATHERING AND DIAGENESIS, THELON BASIN, NORTHWEST TERRITORIES, CANADA.
}

\author{
by
}

QUENTIN GALL, B.Sc., M.Sc.

\author{
A thesis submitted to the \\ Faculty of Graduate Studies and Research \\ in partial fulfilment of \\ the requirements for the degree of \\ Doctor of Philosophy \\ Department of Earth Sciences \\ Carleton University
Ottawa, Ontario \\ 1994 \\ - copyright \\ 1994, Quentin Gall
}


National Library

of Canada

Acquisitions and

Bibliographic Services Branch

395 Wellington Street

Ottawa, Ontario

K1A ON4
The author has granted an irrevocable non-exclusive licence allowing the National Library of Canada to reproduce, loan, distribute or sell copies of his/her thesis by any means and in any form or format, making this thesis available to interested persons.
L'auteur a accordé une licence irrévocable et non exclusive permettant à la Bibliothèque nationale du Canada de reproduire, prêter, distribuer ou vendre des copies de sa thèse de quelque manière et sous quelque forme que ce soit pour mettre des exemplaires de cette thèse à la disposition des personnes intéressées.

L'auteur conserve la propriété du droit d'auteur qui protège sa thèse. Ni la thèse ni des extraits substantiels de celle-ci ne doivent être imprimés ou autrement reproduits sans son

autorisation.
The author retains ownership of the copyright in his/her thesis. Neither the thesis nor substantial extracts from it may be printed or otherwise reproduced without his/her permission. 
Narne Quentin Ga11

Dissertation Abstracts International is arranged by broad, general subject categories. Please select the one subject which most nearly describes the content of your dissertation. Enter the corresponding four-digit code in the spaces provided.

\section{Subject Categories}

\section{THE HUMANITIES AND SOCIAL SCIENCES}

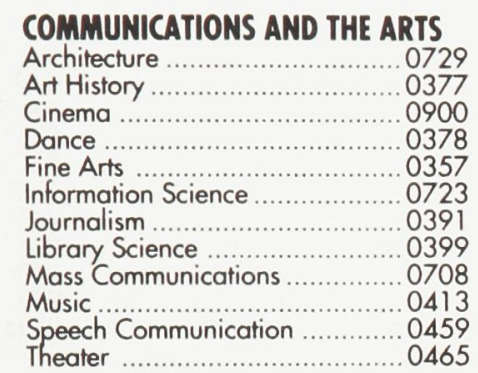

\section{EDUCATION}

\section{General .........}

Administration ....................... 0514

Agricultural ....................... 0517

A

Bilingual and Multicultural .......... 0282

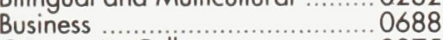

Community College .................... 0275

Curriculum and Instruction ......... 0727

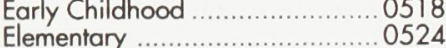

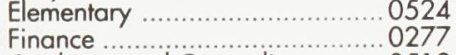

Guidance and Counseling ..........0519

Health .................................. 0680

Higher ................................... 0745

History of .............................. 0520

Home Economics ....................... 0278

Industrial .......

Language and Liferature ............ 0279

Mathematics ......................... 0282

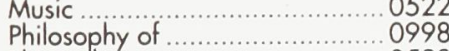

Physical ................................ 0523

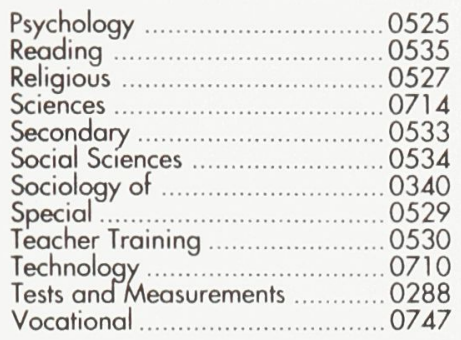

\section{LANGUAGE, LITERATURE AND \\ LINGUISTICS}

Language

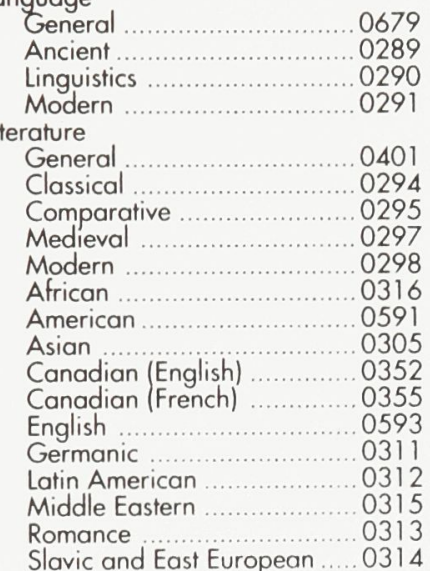

\section{THE SCIENCES AND ENGINEERING}

\section{BIOLOGICAL SCIENCES}

Agriculture

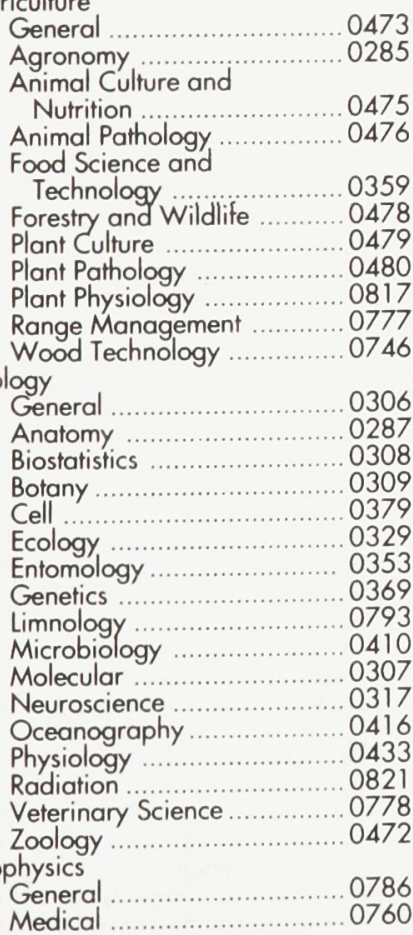

EARTH SCIENCES

Biogeochemistry

Geochemistry
Geodesy

Geology

Geophysics

Mineralogy

Paleobotany

Paleoecology

Paleontology

Paleozoology

Palynology

Physical Geography

Physical Oceanography

HEALTH AND ENVIRONMENTAL SCIENCES

Environmental Sciences

Health Sciences

General

Audiology

Dentistry

Education

Hospital Management

Human Development

Immunology

Medicine and Surgery

Mental Health

Nursing

Nutrition 0570

Obstetrics and Gynecology .0380

Occupational Health and

Therapy

Ophthalmology

Pathology

Pharmacology

Pharmacy

Physical Therapy

Public Health

Radiology

Recreation

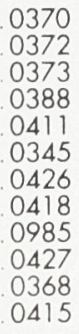

0381

0419

0572

0382

0573

0574

0575
Chemotherapy

\section{PHILOSOPHY, RELIGION AND} THEOLOGY

Philosophy

Religion

Biblical Studies

Clergy.

History of

Philosophy of

Theology

\section{SOCIAL SCIENCES}

American Studies

Anthropology

Archaeology

Cultural

siness Administration

usiness Adr

$$
\text { Accounting }
$$

Banking

Management

Marketing .

Canadian Studies

Economics

General ...

Commerce-Business

Finance

History

Labor

Folklore.

Geography

Gerontology

History

General
0422

0318

0321

0319

0320

0322
0469

0323

0324

.0326

.

0310

0272

0770

0338

0385

0501

0503

0505

0508
0509

0509
0510

0511

0358

0366
0351

0578

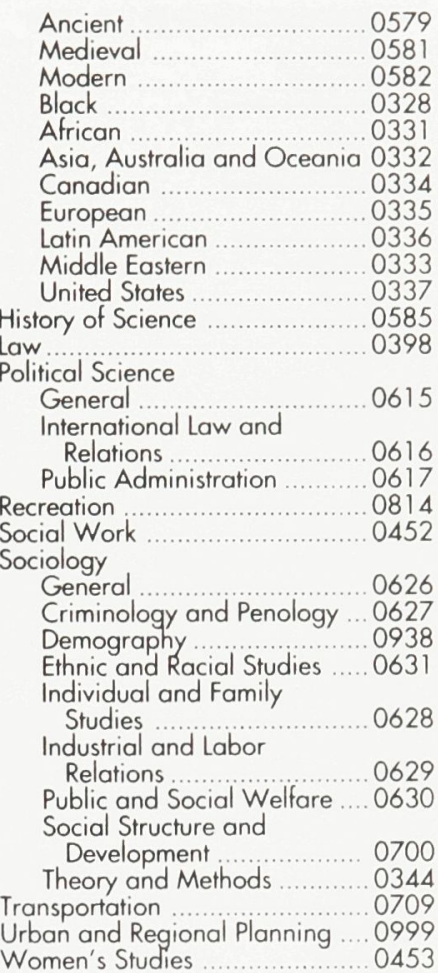

Women's Studies
Speech Pathology
Toxicology
Home Economics ...................

\section{PHYSICAL SCIENCES}

Pure Sciences

Chemistry

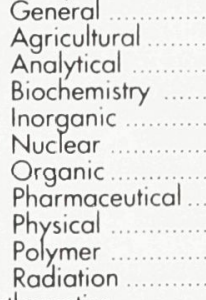

Radiation ...

Physics

General .

Acoustics

Astronomy and

Astrophysics

Atmospheric Science

Atomic

Electronics and Electricit

Elementary Particles and

High Energy

Fluid and Plasma

Molecular

Nuclear

Optics

Radiation

Solid State
Statistics

Applied Sciences

Computer Science
Applied Mechanics
0460

0383

0386

0485

0749

0486

0487
0488

0738

0490

0491

0494

0495

0754

0605

0986

0606

0608

0748

0607

0798

0759

0609

0610

0752

0756

0463

0346

0984
Engineering

General

Agrospace

Automotive

Biomedical ....

Chemical

Civil

Electronics and Electrical

Heat and Thermodynamics Hydraulic

Industrial

Marine

Materials Science

Mechanical

Metallurgy

Mining

Nuclear

Packaging

Petroleum

Sanitary and Municipal

System Science

Geotechnology

Operations Research

Plastics Technology

Textile Technology

\section{PSYCHOLOGY}

Behavioral.

Clinical

Developmental

Experimenta

Industrial

Personality

Physiological

Psychobiology

Psychometrics

Social

0537

0538

0539
0540

054

0542

0543

0544

0348
0545

0546

0547

0794

0548

0743

0551

0552

0549

0765

0554

0790
0428

0796

0796

0994

062

0384

0622

0620

0623 


\section{Carleton University}

Ottawa, Canada K1S $5 J 7$

Thesis contains black and white and/or coloured graphs/tables/photographs which when microfilmed may lose their significance. The hardcopy of the thesis is available upon request from Carleton University Library. 


\section{THESIS ABSTRACT}

In the northwestern part of the Canadian Shield, the ca. $1.72 \mathrm{Ga}$ Thelon Formation forms the basal stratigraphic unit of the Thelon Basin, and overlies a paleoweathered zone (Thelon paleosol). The Thelon paleosol developed on igneous and metamorphic rocks, the youngest of which is the $1.76 \mathrm{Ga}$ Pitz Formation, prior to erosion and burial by quartzose sediments of the Thelon Formation in a terrestrial environment. The Thelon Formation and Thelon paleosol are not deformed or metamorphosed.

This thesis documents the nature of the Thelon paleosol and diagenesis of the overlying basal Thelon Formation in four localities along the southern and eastern perimeter of the Thelon Basin. The pedogenic and diagenetic alteration described herein serves as a baseline for comparison with alteration associated with unconformity-related mineralization beneath the Thelon Basin.

The Thelon paleosol is generally characterized by the following changes from fresh protolith, through paleosol, to the base of the overlying Thelon Formation: (a) saprolitic disruption of the protolith; (b) reddening of the paleosol as a consequence of oxidation; (c) increase in dissolution of feldspar (plagioclase > alkali feldspar), increase in the degree of iron oxidation of biotite, chlorite and garnet, and an increase in the abundance of authigenic kaolinite, illite and hematite cement; (d) a loss of $\mathrm{TiO}_{2}$, total $\mathrm{Fe}, \mathrm{FeO}, \mathrm{MnO}, \mathrm{MgO}, \mathrm{CaO}, \mathrm{Na}_{2} \mathrm{O}, \mathrm{K}_{2} \mathrm{O}, \mathrm{P}_{2} \mathrm{O}_{5}, \mathrm{U}, \mathrm{Zr}, \mathrm{Rb}, \mathrm{Sr}, \mathrm{Ba}$; 
(e) a depletion in rare earth elements, but no fractionation between light and heavy rare-earth elements; (f) a gain in $\mathrm{Fe}_{2} \mathrm{O}_{3}$; and (g) an increase in Chemical Index of Alteration (CIA) values. Although phyllosilicates, minor dolomite, and hematite appear to have developed during paleoweathering, minerals unique to the Thelon paleosol compared to the diagenetic minerals of the overlying Thelon Formation are lacking, and therefore the Thelon paleosol cannot be characterized on the basis of mineralogy alone.

The Thelon paleosol has an approximate maximum thickness of 59 metres. The fabric of the protoliths appears to have influenced Thelon paleosol development, with thinner profiles formed on massive protoliths compared to metamorphic protoliths. The behaviour of iron in the paleosol profiles, and the presence of hematite, suggest that paleoweathering took place under an oxidizing atmosphere.

Burial diagenesis within the Thelon Formation caused the following to occur: (a) the formation of stylolites as a result of grain-to-grain compaction; and (b) the formation of (in paragenetic sequence) quartz cement, kaolinite, poorly crystallized aluminous illite, minor chlorite, fluorapatite and an alumino-phosphate-sulphate (APS) mineral, and hematite. The persistence of poorly crystalline aluminous illite and kaolinite, and the clustering of the $\delta^{18} \mathrm{O}$ and $\delta \mathrm{D}$ values for the kaolinite between the $25^{\circ} \mathrm{C}$ and $50^{\circ} \mathrm{C}$ isotherms for kaolinite stability, suggest that the basal Thelon Formation sediments have remained within the diagenetic realm $\left(<200^{\circ} \mathrm{C}\right)$ 
since deposition.

The Thelon paleosol has been compacted and chemically altered during burial diagenesis of the overlying Thelon Formation, producing: (a) stylocumulates, (b) local quartz and hematite veining, (c) the APS mineral, (d) pervasive illitization of kaolinite, and (e) re-equilibration of oxygen and hydrogen isotopes of kaolinite.

On the basis of stratigraphy, paleocurrent data, geochronology, diagenesis in basal strata, and similarity in paleosol character, the Thelon paleosol and Thelon Basin strata can be correlated with similar basal paleosols and sedimentary successions within the Athabasca, Hornby Bay and Elu basins in the northwestern part of the Canadian Shield. This correlation characterizes the Thelon paleosol as a part of the widespread early Proterozoic Matonabbee unconformity. The distribution of paleosols associated with the Matonabbee unconformity delimits areas of relative tectonic stability and subaerial exposure following the amalgamation of the early Proterozoic supercontinent Laurentia. 


\section{ACKNOWLEDGEMENTS}

I wish to acknowledge my advisors, Dr. J.A. Donaldson and Dr. D.F. Sangster, for their unfailing support, guidance and friendship throughout the preparation of this thesis. This thesis was financially supported by grants from the 1987-1991 Canada Northwest Territories Mineral Development Agreement, Department of Indian Affairs and Northern Development Northern Studies Training Program and the Natural Sciences and Engineering Research Council of Canada. I also wish to acknowledge the constant moral support given by my family; in particular, my loving wife Mary, and my father (deceased 1990) whose striving spirit and example of persistence provided motivation for the completion of this study. 
TABLE OF CONTENTS

PAGE

ACCEPTANCE SHEET

ii

THESIS ABSTRACT

iii

ACKNOWLEDGEMENTS

vi

TABLE OF CONTENTS

vii

LIST OF FIGURES

xiii

LIST OF TABLES

xvii

PROLOGUE

XX

CHAPTER ONE: Precambrian paleosols in Canada

Abstract

$1-2$

Introduction

$1-3$

Data base

$1-4$

Criteria for recognizing Precambrian paleosols

$1-5$

Paleosol diagenesis

Metamorphosed paleosols

$1-13$

Conclusions

Acknowlegements 
References

\section{CHAPTER TWO:}

SECTION ONE: The Proterozoic Thelon paleosol,

Abstract

Introduction

$2-1-3$

Analytical methods

$2-1-5$

Results

Profile 1

Profile 2

2-1-9

Profile 3

$2-1-11$

Profile 4

Discussion

2-1-16

Summary and conclusions

$2-1-25$

Acknowledgements

$2-1-27$

References

2-1-28

SECTION TWO: Paleoweathering of the Pitz

Formation 
Introduction

$\begin{array}{ll}\text { Physical weathering } & 2-2-2\end{array}$

Mineral alteration $\quad 2-2-3$

Geochemical data 2-2-4

Discussion and conclusions $2-2-6$

$\begin{array}{ll}\text { References } & 2-2-8\end{array}$

SECTION THREE: Behaviour of rare earth elements in the Thelon paleosol

$\begin{array}{ll}\text { Introduction } & 2-3-2\end{array}$

Results $2-3-3$

$\begin{array}{ll}\text { Discussion } & 2-3-6\end{array}$

Observations and conclusions 2-3-9

References 2-3-9

CHAPTER THREE:

SECTION ONE: Diagenesis: Thelon Formation and

Thelon paleosol 3-1-1

Introduction $3-1-2$

Diagenetic minerals 
Quartz cement

$3-1-3$

Phyllosilicates

$3-1-5$

Phosphatic cements

3-1-11

Hematite cement

3-1-15

Discussion

Thelon Formation diagenesis

3-1-16

Thelon paleosol diagenesis

Conclusions

3-1-32

References

$3-1-35$

SECTION TWO: Stable isotope analysis of kaolinite

Introduction

$3-2-2$

Sampling and analytical technique

$3-2-4$

Results

$3-2-5$

Discussion

$3-2-7$

Conclusions and interpretations

References

$3-2-12$ 
CHAPTER FOUR: The early Proterozoic Thelon paleosol as part of the Matonabbee unconformity in the northwestern Canadian Shield

Abstract

Introduction

Thelon paleosol

Correlative paleosols

Sub-Manitou Falls Formation paleosol 4-12

Sub-Hornby Bay Group paleosol 4-13

Sub-Ellice Formation paleosol 4-15

Interbasin correlation and the Matonabbee unconformity 4-16

$\begin{array}{ll}\text { Conclusion } & 4-18\end{array}$

$\begin{array}{lr}\text { Acknowledgement } & 4-19\end{array}$

References $\quad 4-20$

APPENDIX I: Analytical techniques $\quad$ AI-1

X-ray diffractometry

Illite crystallinity

Infrared spectroscopy 
Ferrous iron determination

AI-5

Stable isotope determination $\quad$ AI-5

Uranium determination $\quad$ AI-6

Inductively coupled argon plasma analyses $\quad$ AI-6

Electron probe microanalyses $\quad$ AI-8

Scanning electron microscope - energy dispersive

analyses

AI-8

References

AI-9

APPENDIX II: Additional analyses $\quad$ AII-1

$\begin{array}{lll}\text { References } & \text { AII-4 }\end{array}$

$\begin{array}{lll}\text { Tables } & \text { AII-5 }\end{array}$ 


\section{LIST OF FIGURES}

PAGE

\section{CHAPTER ONE}

1.1 Precambrian paleosol distribution map

\section{CHAPTER TWO}

\section{SECTION ONE}

2.1.1 Generalized geology about the Thelon Basin

2.1.2A to 2.1.2F Profile 1 concentration ratios

2.1.3 CIA for four Thelon paleosol profiles

2.1.4 Incipient paleoweathering

2.1.5 Illite pseudomorphous after kaolinite

2.1.6 Stylocumulates

2.1.7 Thelon Fm. quartz cement and kaolinite

2.1.8A to $2.1 .8 \mathrm{~F}$ Profile 2 concentration ratios

2.1.9 Altered garnet porphyroblasts

2.1.10 Thelon Fm. illite after kaolinite 
LIST OF FIGURES

PAGE

CHAPTER ONE

1.1 Precambrian paleosol distribution map

$1-37$

\section{CHAPTER TWO}

SECTION ONE

2.1.1 Generalized geology about the Thelon Basin

2-1-39

2.1.2A to $2.1 .2 \mathrm{~F}$ Profile 1 concentration ratios

$2-1-40$

2.1.3 CIA for four Thelon paleosol profiles

$2-1-46$

2.1.4 Incipient paleoweathering

2-1-47

2.1.5 Illite pseudomorphous after kaolinite

$2-1-47$

2.1.6 Stylocumulates

$2-1-47$

2.1.7 Thelon Fm. quartz cement and kaolinite

$2-1-47$

2.1.8A to $2.1 .8 \mathrm{~F}$ Profile 2 concentration ratios

$2-1-48$

2.1.9 Altered garnet porphyroblasts

$2-1-54$

2.1.10 Thelon Fm. illite after kaolinite

$2-1-54$

2.1.11A to $2.1 .11 \mathrm{~F}$ Profile 3 concentration ratios

$2-1-55$

2.1.12 Feldspar alteration to kaolinite

$2-1-54$ 
2.1.13A to $2.1 .13 \mathrm{~F}$ Profile 4 concentration ratios

2.1.14 A-CN-K ternary plots $2-1-67$

2.1.15 Composite paragenetic sequence

$2-1-68$

SECTION TWO

2.2.1 Pitz Fm. sample locality map

2.2.2 Polyhedral ped structure

2-2-13

2.2.3 Corestones

2-2-13

2.2.4 Horizontal parting in Pitz Fm.

2-2-13

2.2.5 Illite and hematite alteration

2-2-13

2.2.6A to 2.2.6Q Harker plots

2-2-14

\section{SECTION THREE}

2.3.1A to 2.3.1E Profile $1 \mathrm{REE}$ concentration ratios

$2-3-13$

2.3.2 Profile 1 REE distribution

2-3-18

2.3.3A to 2.3.3E Profile 2 REE concentration ratios

$2-3-19$

2.3.4 Profile 2 REE distribution

$2-3-24$

2.3.5 A to 2.3.5E Profile $4 \mathrm{REE}$ concentration ratios

$2-3-25$

2.3.6 Profile 4 REE distribution

$2-3-30$ 


\section{CHAPTER THREE}

SECTION ONE

$\begin{array}{ll}\text { 3.1.1 Quartz overgrowths 3-1-59 } & \text { 3 }\end{array}$

3.1.2 Quartz cements 3-1-59

3.1.3 Interstitial quartz and kaolinite 3-1-59

3.1.4 Interstitial diagenetic minerals $3-1-59$

3.1.5 Vermiform kaolinite from feldspar alteration 3-1-60

3.1.6 Kaolinite infrared absorption spectrum 3-1-61

3.1.7 Kaolinite infrared absorption spectrum 3-1-62

3.1.8 Interstitial quartz and bladed kaolinite 3-1-60

3.1.9 Interstitial quartz and twinned kaolinite 3-1-60

3.1.10 Illite pseudomorphous after kaolinite 3-1-60

3.1.11 Illite formation on feldspar 3-1-65

3.1.12 Profile 3 illite crystallinity 3-1-63

3.1.13 Profile 4 illite crystallinity 3-1-64

3.1.14 Interstitial fluorapatite 3-1-65

3.1.15 Interstitial fluorapatite cutting kaolinite 3-1-65

3.1.16 SEM of bladed fluorapatite 3-1-65

3.1.17 EDS of bladed fluorapatite 3-1-66

3.1.18 APS crystals cutting phyllosilicates 3-1-67

3.1.19 APS crystals cutting phyllosilicates 3-1-67 
3.1.20 EDS of an APS crystal 3-1-68

3.1.21 SEM of zoned APS crystal 3-1-67

3.1.22 Energy dispersive line scan spectra of APS 3-1-67

3.1.23 Ternary plot of APS crystals 3-1-69

3.1.24 Hematite cement $3-1-70$

3.1.25 Bladed hematite cement 3-1-70

3.1.26 Composite paragenetic sequence 3-1-71

SECTION TWO

3.2.1 Comparison of $\delta \mathrm{D}$ and $\delta^{18} \mathrm{O}$ values with other studies

3.2.2 $\delta \mathrm{D}$ vs $\delta^{18} \mathrm{O}$ plot of paleosol and sandstone kaolinite $\quad 3-2-21$

CHAPTER FOUR

4.1 Distribution of Paleoproterozoic basins in the NWT 4-31

4.2 Summary of Thelon paleosol geochemical trends 4-32

4.3 Diagram depicting alteration fluid flow 4-33

4.4 Geologic map of Fault River area 4-34

4.5 Geologic map of Ovayor Hill area 4-35

4.6 Chronostratigraphic correlation between basins $\quad 4-36$ 


\section{LIST OF TABLES}

PAGE

\section{CHAPTER ONE}

1.1 Mineralogy of metamorphosed Precambrian paleosols

$1-38$

\section{CHAPTER TWO}

SECTION ONE

2.1.1 XRF analyses of Profiles 1, 2, 3 and 4

2-1-69

2.1.2 $\mathrm{R}$ values for four paleosol protoliths

$2-1-73$

SECTION TWO

2.2.1 XRF of Wharton Group samples

SECTION THREE

2.3.1 REE analyses of Profiles 1, 2 and 3 
2.3.2 Correlation coefficients for Profile 1 REE

2.3.3 Correlation coefficients for Profile 2 REE

2.3.4 Correlation coefficients for Profile 3 REE

2-3-36

\section{CHAPTER THREE}

SECTION ONE

3.1.1 Point counts for Thelon Fm. samples

3.1.2 Electron microprobe analyses of kaolinite

3.1.3 Illite crystallinity measurements

3.1.4 Electron microprobe analyses of fluorapatite

3.1.5 EDX analyses of APS crystals

3.1.6 Structural formulae for APS crystals

3.1.7 Comparison of pedogenic and diagenetic clays

$3-1-82$

SECTION TWO

3.2.1 $\delta \mathrm{D}$ and $\delta^{18}$ Ovalues for kaolinite samples 


\section{CHAPTER FOUR}

4.1 XRF analyses of sub-Ellice Fm. paleosol profile

APPENDIX II

AII.1 XRF analyses of additional samples

AII-5 


\section{PROLOGUE}

This Ph.D. thesis evolved from a project, titled "Diagenesis of Middle Proterozoic basins, Churchill and Bear Provinces", funded by the 1987-1991 FederalTerritorial Mineral Development Agreement (MDA). The project scientists were A.R. Miller (Geological Survey of Canada) and J.A. Donaldson (Carleton University). The original intent of the thesis study was to geologically characterize the paleosol beneath the Proterozoic Thelon Formation in the Northwest Territories, and to document the effects of overprinting that epigenetic unconformity-related uranium mineralization has had on the paleosol. Unfortunately, continuous mineralized and unmineralized drill core containing Thelon Formation, paleosol, and unweathered protolith, could not be obtained from the two areas in which uranium mineralization has been discovered, the Boomerang Lake and Kiggavik deposits. Consequently, the thesis study was revised to include a description of the diagenetic state of the Thelon Formation, which, like the paleosol and mineralization, had not been fully documented.

This thesis consists of four chapters which have been submitted in part to journals for publication. Each chapter or section is self-contained, with an introduction, body and conclusions. References, figures and tables are at the end of each section or chapter; those parts that have been published are presented in 
journal format. Details on analytical procedures used throughout the thesis are presented in Appendix I. Appendix II contains additional analyses of weathered and unweathered rocks associated with the Thelon paleosol, to provide additional evidence for the weathering trends described in Section One, Chapter Two.

As study of the paleosol (herein called the Thelon paleosol) progressed, information on other Precambrian paleosols, especially those in Canada, was compiled as a basis for comparison with results from my study of the Thelon paleosol. The compilation revealed that little is known about Precambrian paleosols, and that more basic research is needed. The compiled data were presented at a special session on Precambrian sedimentology during the 1990 GAC-MAC meeting, and a manuscript was subsequently prepared that lists the documented Precambrian paleosol in Canada and their physical and chemical characteristics, and discusses the 'state of the art' for Precambrian paleosol studies in Canada and elsewhere. This manuscript, which was published in the Canadian Journal of Earth Sciences in 1992, is presented as the first chapter of this thesis.

Chapter Two pertains to the Thelon paleosol. Section One consists of a manuscript, submitted to Precambrian Research, describing characteristics of the paleosol in four localities from the Thelon Basin. Section Two describes paleoweathered rhyolite, also part of the Thelon paleosol, but from which no paleoweathering profiles could be sampled. Section Three describes the behaviour 
of rare earth elements within three profiles through the Thelon Paleosol.

Section One of Chapter Three describes the diagenesis of the basal Thelon Formation. Emphasis has been placed on several new occurrences of a rare hydrated alumino-phosphate-sulphate mineral identified in diagenetic cements within both the Thelon Formation and the underlying Thelon paleosol. Section One also outlines the evidence for diagenetic overprinting of the Thelon paleosol. As the thesis study progressed, it became apparent that kaolinite in the Thelon Formation could not be distinguished from kaolinite in the Thelon paleosol by means of conventional petrographic and analytical methods. In an attempt to distinguish kaolinite in the two settings, a study of the hydrogen and oxygen stable isotope composition of the kaolinite was undertaken, and is presented in Section Two of Chapter Three.

Chapter Four considers the Thelon paleosol in a regional context. Various lines of evidence are presented in this chapter to argue that the Thelon paleosol is related to the widespread Matonabbee unconformity which developed across the northwestern part of the Canadian Shield during the Early Proterozoic, and can be correlated with similar paleosols at the base of the Athabasca Basin, Hornby Bay Basin and Elu Basin. Chapter Four was written as a manuscript for a special publication compiling contributions to the International Geological Correlation Program project 317, Paleoweathering Records and Paleosurfaces. 
CHAPTER ONE

PRECAMBRIAN PALEOSOLS IN CANADA. 


\begin{abstract}
Although at least 38 Precambrian paleosols have been reported in Canada, few have received the attention afforded most other geological phenomena. The most intensively studied of these are widely distributed early Proterozoic paleosols associated with the sub-Huronian and Matonabbee (new name) unconformities. Criteria which have been most useful in identifying Precambrian paleosols in Canada include: macrostructures (ascending protolith disruption, saprolith and corestones); micromorphology (sepic texture and peds); mineralogical changes (dissolution, transformation); geochemical signatures (ascending depletion of some elements, characteristic weathering indices); and distinctive colour contrast. Alteration through physical and geochemical diagenetic overprinting of the paleosols, evident in many Canadian examples, includes paleosol compaction, veins cutting pedogenic features, and widespread alkali and alkaline earth element metasomatism. Metamorphism and deformation also tend to mask pedogenic features, as attested by the scarcity of documented occurrences of medium- to high-grade metamorphosed Precambrian paleosols in Canada. The recognition of other Precambrian paleosols in metamorphosed terranes could be aided by systematic detailed studies of rocks beneath unconformities to assess geochemical gradients in metamorphic minerals rich in $\mathrm{Si}, \mathrm{Al}$ and $\mathrm{Fe}$. Geochronological constraints on Precambrian paleosol development might reinforce previously proposed stratigraphic correlations, suggest new correlations, and serve to delimit times and areas of relative tectonic stability and subaerial exposure.
\end{abstract}




\section{Introduction}

Unconformities, by definition, represent periods of erosion (hiatus) and/or nondeposition (lacuna). Associated paleosols correspond to the lacuna, and are therefore an integral part of the record represented by the unconformity. Unfortunately, the processes of erosion, diagenesis, metamorphism and deformation tend to remove or mask paleosols, especially those formed during the Precambrian. Nevertheless, once identified, Precambrian paleosols afford an opportunity to: (a) interpret the geologic history of an area; (b) interpret the relative influence of soil-forming factors (organisms, climate, parent material, topography, time (Jenny 1941)) in the development of the paleosol; (c) gauge paleoatmospheric composition; (d) act as a datum for correlation; (e) act as a sequence boundary for basin analysis; and (f) track unconformity-related mineralization.

Apart from a frequently referenced study of two in-situ Archean paleosols by Schau and Henderson (1983), most studies of paleosols of Precambrian age in Canada have focused on sub-Huronian Supergroup paleosols in Ontario, the sub-Athabasca Group paleosol in Saskatchewan, and probable correlatives of the latter in the Northwest Territories. This paper identifies all Precambrian paleosols discovered in Canada to date, and summarizes criteria that are useful in 
their recognition in both unmetamorphosed and metamorphosed terranes. The paper also addresses an area of increasing importance in paleosol studies, the diagenetic alteration of Precambrian paleosols during burial.

\section{Data base}

This paper offers some observations based on a compilation of published data on Precambrian paleosols in Canada, augmented by the author's familiarity with 11 of these paleosols. To date the author has compiled information on 38 documented paleosols, or features interpreted as paleoweathered zones, in Precambrian rocks within Canada. Over $90 \%$ of these occur at angular unconformities, where they are easier to detect and therefore more likely to be documented than at disconformities. A survey of the literature on Precambrian paleosols in Canada reveals that only $50 \%$ of the documented examples are greater than a paragraph, and only $60 \%$ of the well-documented examples include chemical analyses (mostly partial) of the paleoweathered rocks. Approximately $60 \%$ of the chemically analysed paleosols are from two regions in Canada (sub-Huronian Supergroup and Matonabbee ${ }^{1}$ unconformities), thus biasing our understanding of Canadian Precambrian paleosols.

1 For descriptive purposes, the correlative unconformities/paleosols underlying the Hornby Bay, Elu, Thelon and Athabasca basins (Gall and Donaldson 1990b) are referred to as the Matonabbee unconformity. Matonabbee was the 
Chipawayan Indian guide without whom Samuel Hearne would not have been able to complete his historic expedition from Hudson Bay to Coronation Gulf in 1770.

The geographic locations and approximate ages of the 38 paleosols are shown in Fig. 1.1. The lack of fossils and minerals suitable for directly dating Canadian Precambrian paleosols dictates that the age of any paleosol has to be constrained by the ages of the youngest protolith and the oldest overlying stratigraphic unit. In Fig. 1.1, where the age of a paleosol is not well known, but where some geochronologic constraints exist, the paleosol locality number is placed in the column designated by "?". Where there are no geochronologic constraints and thus the age of the paleosol is unknown, the number has been entered in the column marked "??"; in such cases, the assigned age has been inferred from regional geological considerations.

\section{Criteria for recognizing Precambrian paleosols}

Paleosols in the rock record are obscured by burial diagenesis, orogenesis and attendant metamorphism and deformation. This overprinting is common in the Precambrian, and makes the task of identifying Precambrian paleosols difficult. Criteria that can be used to identify these paleosols are derived from studies of modern and Phanerozoic soils and weathering processes (e.g., Birkland 1984; Retallack 1988; Allen and Wright 1989). However, one must bear in mind the 
relatively unoxygenated state of the Archean atmosphere, and the differences in organic activity in the Precambrian (compared to the Phanerozoic), when applying these criteria to Precambrian rocks.

Destratification (i.e., the destruction of protolith structure and texture) may occur as a result of organic activity, shrinking and swelling of phyllosilicates (vertisolic soils), freezing and thawing of ground water in cold regions, and the movement of gas through soil (Allen and Wright 1989). To date, none of these processes has been identified as an agent of destratification for Precambrian paleosols in Canada. Soil stratification, or horizonation, results mostly from vertically directed fluid flow and particle translocation. As pointed out by Retallack (1986), surface A horizons, saprolitic C horizons, and incipiently weathered protolith ( R) are typically the only soil divisions that can be recognized in Precambrian paleosols. Paleosols associated with the ca. 1.74 Ga Matonabbee unconformity show an upper hematitic zone, overlying a less oxidized saprolitic and clay-rich zone, above incipiently weathered protolith, with no clear zone boundaries. Such stratification has not been identified in other Precambrian paleosols in Canada.

Macrostructural features, visible in outcrop, have been widely used to identify paleosols and infer paleoweathering. The gradual upward increase in disruption of original protolith textures and structures to form a saprolith has been noted in a number of Precambrian paleosols in Canada (e.g., Thelon, Athabasca, Elliot 
Lake, Lake Timiskaming, Eyapamikama Lake). Other reliable and easily recognized features are corestones and exfoliation shells (c.f., Ruxton and Berry 1957). Corestones have been identified in paleosols at Nonacho Lake, Flin Flon, Richmond Gulf, Lac Mistassini and Saglek Bay (Fig. 1.1).

Several distinctive macrostructural paleosol features occur in Precambrian carbonate-dominated karst facies. These include irregular topography, dolines, grikes, geopetal structures, cavernous porosity and collapse breccia. Such features have been observed at Steep Rock, September Lakes and Kanuyak Island (Fig. 1.1). Precambrian caliche facies, characterized by distinctive carbonate morphologies (e.g., grain coatings, nodules, laminar horizons) and $\mathrm{K}$ horizons (Gile et al. 1966, 1981), are associated with the Fault River, Kanuyak Island, Bathurst Inlet and Ogilvie Mountain paleosols (Fig. 1.1). One of the Steep Rock paleosols, the Buckshot Ore, may be a lateritic bauxite, because of the presence of hematite pisolites within a gibbsite, kaolinite, hematite and goethite matrix. Silcretes also have been identified (Ross and Chiarenzelli 1985; Mustard and Donaldson 1990; Pelechaty 1990). Karst features and duricrusts can be used as evidence of subaerial exposure and weathering, but need not have formed directly at the exposed paleosurface (Esteban and Klappa 1983; James and Choquette 1988).

Micromorphological features are produced by destruction of the protolith and the 
concomitant development of a skelsepic plasmic fabric (Brewer and Sleeman 1960; Brewer 1976). In response to mineral dissolution and translocation, the more mobile components form a plasma of three-dimensional cutans surrounding the relatively immobile, less soluble grains and aggregates (peds). These textural features have been recognized in Canada in the ca. 1.74 Ga Thelon paleosol (Gall and Donaldson 1990a) and the sub-Huronian Supergroup paleosol near Elliot Lake (Gay and Grandstaff 1980).

Another criterion which may be useful for the identification of Precambrian paleosols is their peculiar mineralogy compared to adjacent lithologies. Ideally, protolith mineral alteration should uniformly decrease with depth in a paleosol. However, fluids may follow protolith structures, such as metamorphic fabric or jointing, causing localized mineral dissolution. The alteration rate of protolith depends on its mineral composition (Goldich 1938; Keller 1955). Based on the available mineralogical data for Canadian Precambrian paleosols, it is apparent that plagioclase feldspar is the first aluminosilicate mineral to be pedogenically altered, together with ferromagnesian minerals such as olivine, pyroxene and biotite. Minor and/or accessory protolith minerals, including rutile, ilmenite, magnetite, chlorite, amphibole, sphene, zircon, garnet, pyrite, pyrrhotite, and apatite, have also undergone some degree of pedogenic alteration. Alkali feldspars, quartz and muscovite are unaltered in most paleosols, but there are exceptions (e.g., Caty 1976; Chiarenzelli 1983). Where the protolith 
predominantly consists of carbonate minerals, karsting is common. Neomorphic pedogenic minerals include illite, kaolinite, chlorite, calcite, dolomite, hematite, magnetite, leucoxene, anatase, and, less commonly, quartz (as silcrete), tourmaline, goethite, mixed-layer phyllosilicates, vermiculite and gibbsite.

Geochemical data can complement mineralogical and structural/textural evidence and confirm the identification of paleosols. However, differing interpretations of such data may lead to controversy over whether alteration is due to paleoweathering, diagenesis or hydrothermal activity (e.g., Kalliokoski 1975; Lewan 1977; Holland and Feakes 1989; Palmer et al. 1989). Unfortunately, studies of modern soils rarely include complete major and trace element analyses, making geochemical comparisons with paleosols difficult. Geochemical data from paleosols associated with the Matonabbee and sub-Huronian unconformities suggest that no element is immobile during weathering. Most geochemical profiles in these paleosols show an upward depletion of many elements, including aluminum, zirconium and titanium, from fresh protolith to the unconformity (Macdonald 1980; G-Farrow and Mossman 1988; Gall and Donaldson 1990a; Rainbird et al. 1990; Gall in press). Although aluminum, zirconium and titanium are traditionally considered to be immobile (insoluble) during weathering, and therefore are commonly used to normalize analytical data (Retallack et al. 1984), some studies show that they are not always immobile. Many elements, particularly the alkali and alkaline earth elements, are depleted from the Thelon 
paleosol profiles, suggesting that eluvial processes have predominated.

Chemical weathering indices are another parameter that may help identify Precambrian paleosols (e.g., CIA, Nesbitt and Young 1982; CIW, Harnois 1988; WPI, Reiche 1943; WR, Chittleborough 1991; and abrasion pH, Grant 1969). These weathering indices commonly use molecular proportions to demonstrate an increased loss of soluble elements relative to less soluble elements with progressive weathering. $\mathrm{CIA}^{\star}$ has been applied to the Thelon paleosol, and there is a well defined positive slope (CIA decreases with depth) within the profiles (Gall and Donaldson 1990a).

\footnotetext{
${ }^{*} \mathrm{CIA}=\left[\mathrm{Al}_{2} \mathrm{O}_{3} /\left(\mathrm{Al}_{2} \mathrm{O}_{3}+\mathrm{K}_{2} \mathrm{O}+\mathrm{CaO}+\mathrm{Na}_{2} \mathrm{O}\right)\right] \mathrm{X}$ 100, where molecular proportion of $\mathrm{CaO}$ is for silicate fraction of the rock.
}

Colour, which is a function of mineralogy, is another criterion which is useful for identifying Precambrian paleosols. Subaerial exposure of a protolith and oxidation causes reddening (rubifaction) of the paleosol, especially in its upper parts. A vertical colour gradation from a reddened hematitic top to a grey-green illitic and chloritic base has been noted in the paleosols associated with the Matonabbee unconformity (Macdonald 1980; Chiarenzelli 1983; Gall and Donaldson 1990a). In many cases, the reddened upper zone is evident in outcrop, 
especially where the paleosol is developed on a leucocratic protolith; this can generally be seen from a great distance in areas north of the tree line. Mottling due to local redox changes may also develop within the paleosol, as can be seen in the Pitz Formation below the Thelon Formation, where dark red (10 R 3/4)* rhyolite is weathered to grey-red $(10 \mathrm{R} 4 / 2)^{\star}$ and pale red $(10 \mathrm{R} 6 / 2)^{\star}$ colours (Gall and Donaldson 1990a), especially along surfaces between peds. Even those paleosols that are drab, due to gleization, oxygen buffering capacity of the protolith or development under an unoxidized atmosphere, show subtle colour contrasts in comparison to both the protolith and the overlying unit.

* Munsell colour system

\section{Paleosol diagenesis}

As previously mentioned, after a paleosol is buried, diagenetic and metamorphic processes tend to mask the original pedogenic features. This is particularly true in Precambrian terranes where paleosols may have been subjected to repeated and protracted episodes of metamorphism and deformation after burial diagenesis.

Burial diagenesis may impart both physical and chemical changes to a paleosol. A highly weathered paleosol is likely to become compacted. A manifestation of 
such compaction appears to be present locally in the Thelon paleosol (Gall and Donaldson 1990a), in the form of subhorizontal stylocumulates of hematite and recrystallized illite that cut pedogenic mineral phases in paleoweathered granite and gneiss. Detailed petrographic study of the Thelon paleosol has revealed veinlets that cut across pedogenic phases, and are filled with various combinations of quartz, illite, kaolinite and hematite (Gall and Donaldson 1990a). As well, there are anomalous element concentrations in samples from the top of this paleosol. The presence of authigenic phyllosilicates and quartz cement in the overlying Thelon Formation, together with these petrographic and geochemical observations, suggest that diagenetic fluids penetrated the paleosol after erosion and burial (Gall and Donaldson 1990b; Gall in press).

Illitization of pedogenic vermicular kaolinite in the Thelon paleosol probably represents a weak yet extensive potassium metasomatism which took place during diagenesis of the overlying Thelon Formation. Such illitization, documented elsewhere by Matthews and Scharrer (1968) and Eriksson and Soegaard (1985), has been attributed to potassium metasomatism during diagenesis. Potassium metasomatism of basement rocks has taken place during diagenesis of Phanerozoic sedimentary sequences (Duffin et al. 1989; Bethke and Marshak 1990; Harper et al. 1991). Nesbitt and Young (1984, 1989) have presented empirical examples and theoretical arguments to support potassium metasomatism as a late diagenetic reaction. Numerous Precambrian paleosols, in Canada and 
elsewhere, display potassium enrichment that can be attributed to diagenetic overprinting by potassium-rich fluids (e.g., Button and Tyler 1979; Tremblay 1983; Reimer 1986; G-Farrow and Mossman 1988; Rainbird et al. 1990; Wiggering and Beukes 1990). In some of these, potassium-rich fluids, perhaps generated by the alteration of loess in the surface layer of aridic soils (Singer 1988), may have produced pedogenic illite.

Other examples of diagenetic overprinting of Precambrian paleosols are provided by the Lac Mistassini and Lake Timiskaming (Ville Marie) paleosols. The former has been replaced, in part, by dolomite and cut by anthraxolite-, dolomite- and quartz-bearing veins. Chown and Caty $(1979,1983)$ have attributed these features to overprinting of the paleosol during diagenesis of the overlying dolomitic Albanel Formation. Rainbird et al. (1990) have documented calcite near the base of the Ville Marie paleosol, and attributed its formation to early diagenetic processes involving groundwater, after burial by fluvial facies of the Lorrain Formation.

\section{Metamorphosed paleosols}

Many Precambrian paleosols in Canada occur in metamorphosed terranes. The previously described physical features should still be discernable if porphyroblastic mineral growth and deformation have been minimal. Otherwise, reliance has to 
be placed on metamorphic mineral assemblages and, if the paleosol has not been diagenetically altered, geochemical trends. Ideally, the occurrence of lithologic stratification with aluminosilicate-rich phases (e.g., $\mathrm{Al}_{2} \mathrm{SiO}_{5}$ polymorphs, corundum, diaspore, pyrophyllite, kaolinite), which increase in abundance towards a lithologic contact (unconformity), may suggest the presence of a paleosol.

Metamorphosed Precambrian paleosols have been documented at Point Lake, Fraser Lake, Flin Flon, Folster Lake, Cross Lake, Steep Rock and Lac Villebon (Fig. 1.1). The metamorphic minerals of the Point Lake paleosol are white mica and biotite. Quartz-feldspar-sillimanite nodules (fazerkeisel) occur in the Fraser Lake paleosol at and near the contact between foliated granite protolith and graphite-garnet-cordierite-sillimanite paragneiss. Mixed-layer paragonite-illite is the only metamorphic mineral noted by Holland et al. (1989) for the Flin Flon paleosol. The metamorphic minerals in the Folster Lake paleosol are biotite and muscovite, which form a phyllitic matrix surrounding granitic corestones. The metamorphic minerals in the Cross Lake paleosol are hornblende, biotite, garnet and a carbonate mineral. The Steep Rock paleosol contains metamorphic paragonite, muscovite and chlorite. The Lac Villebon paleosol, developed on a protolith of trachyte and tuff, typically consists of quartz, andesine, muscovite, biotite, chlorite and accessory minerals (Vogel 1975); metastable almandine is present in one volcanic flow sample, and kyanite predating rosette/porphyroblastic chloritoid is present in tuff samples. 
Most of the documented, low-grade, phyllosilicate-rich paleosols still retain primary structures which help to reveal their origin (e.g., corestones at Flin Flon and Folster Lake). Paleosols that have been metamorphosed to high grades (e.g., Fraser Lake and Lac Villebon) have lost all primary physical features, but their mineralogy shows that $\mathrm{Al}_{2} \mathrm{SiO}_{5}$ polymorphs are at least metastable phases.

Table 1.1 lists mineral assemblages for some metamorphosed Precambrian paleosols outside Canada. The dominant minerals, in most cases, can be described in terms of the components $\mathrm{Al}_{2} \mathrm{O}_{3}, \mathrm{SiO}_{2}$ and $\mathrm{FeO}_{\mathrm{T}}$, less commonly $\mathrm{MgO}, \mathrm{K}_{2} \mathrm{O}$ and $\mathrm{TiO}_{2}$, and rarely $\mathrm{CaO}$ and $\mathrm{Na}_{2} \mathrm{O}$. A tendency towards more $\mathrm{Al}_{2} \mathrm{O}_{3}$-and $\mathrm{SiO}_{2}$-rich phases as chemical weathering progresses has been theoretically and empirically shown by Nesbitt and Young (1989); metamorphism of such paleosols should produce mineral assemblages dominated by these same components. Metamorphism of a paleosol in which weathering of a silicate-rich protolith ceased at an early stage, or which has been chemically overprinted during diagenesis, may produce mineral assemblages dominated by elements other than $\mathrm{Al}$ and $\mathrm{Si}$.

\section{Conclusions}

To date, thirty eight Precambrian paleosols have been reported in Canada. The best described paleosols are associated with the sub-Huronian and Matonabbee 
unconformities. Features that are most useful in recognizing Precambrian paleosols are: (1) macrostructures, particularly a gradual upward increase in disruption of the protolith to form a saprolith, and the development of corestones; (2) micromorphology, particularly the presence of cutans and peds; (3) mineralogical changes, reflecting increased mineral dissolution upward through the paleosol (plagioclase and ferromagnesian minerals are the most susceptible to alteration, but even quartz and alkali feldspars have undergone dissolution in some Precambrian paleosols); (4) geochemical changes associated with an upward increase in element leaching from the protolith to the top of the paleosol; weathering indices (e.g., CIA) may also be useful chemical parameters for quantifying these changes; and (5) colour variations between the paleosol and adjacent rocks.

Both mechanical and chemical diagenetic overprinting of Precambrian paleosols have been documented. Overprinting commonly is manifested by veinlets filled with diagenetic minerals which transect pedogenic features. However, overprinting may be more pervasive, because of paleosol compaction or alkali and alkaline earth metasomatism during or after burial of the paleosol. Eight Canadian Precambrian paleosols have been described as being metamorphosed. Metamorphic mineral assemblages alone are not sufficient to identify metamorphosed paleosols. Rather, the widespread occurrence of thin lithologies containing $\mathrm{Al}-, \mathrm{Si}-$ and Fe-rich phases immediately below an unconformity, in 
conjunction with one or more of the physical and chemical features cited above, may be definitive.

Paleosols and associated unconformities may be used in stratigraphic correlation, and can help establish areas and times of relative tectonic stability and subaerial exposure. The Matonabbee unconformity and attendant paleosols in the northwestern part of the Canadian Shield, for example, suggest the existence of one such erosion/paleoweathering surface at the end of the early Proterozoic.

\section{Acknowledgements}

I thank the many geologists from the Continental Geoscience and Mineral Resources divisions of the Geological Survey of Canada who contributed information on many of the paleosols listed in Figure 1.1 and used in this overview. Critical review of an earlier version of this paper by J.A. Donaldson (Carleton University), F.W. Chandler, G.D. Jackson and R.H. Rainbird (Geological Survey of Canada) is also appreciated. CJES reviewers P. Mustard (Geological Survey of Canada) and G.M. Young (University of Western Ontario) are also thanked for their constructive comments. Study of the Matonabbee paleosol was financially supported by NSERC (Operating Grant to J.A. Donaldson) and DIAND (Northern Training Grant to the author). 


\section{References}

ALLEN, J.R.L., and WRIGHT, V.P. 1989. Paleosols in siliciclastic sequences. Reading University, Postgraduate Research Institute for Sedimentology, Short Course Notes, No. 001.

ASPLER, L.B., and DONALDSON, J.A. 1986. Paleoclimatology of Nonacho Basin (Early Proterozoic), Northwest Territories, Canada. Palaeogeography, Palaeoclimatology, Palaeoecology, 56: 17-34.

BETHKE, C.R., and MARSHAK, S. 1990. Brine migration across North America - the plate tectonics of groundwater. Annual Reviews of Earth and Planetary Sciences, 18: 287-315.

BIRKLAND, P.W. 1984. Soils and geomorphology. Oxford University Press, New York.

BOSTOCK, H.H. 1983. Precambrian rocks of the Strait of Belle Isle area. In Geology of the Strait of Belle Isle area, northwestern insular Newfoundland, southern Labrador, and adjacent Quebec. Geological Survey of Canada, Memoir 400, pp. 1-73.

BREWER, R. 1976. Fabric and mineral analysis of soils. Kreiger Publishers, New 
York.

BREWER, R., and SLEEMAN, J.R. 1960. Soil structure and fabric: their definition and description. Journal of Soil Science, 11: 172-185.

BUTTON, A., and TYLER, N. 1979. Precambrian paleoweathering and erosion surfaces in southern Africa: a review of their character and economic significance. University of Witwatersrand, Economic Geology Research Unit, Information Circular 135.

CAMPBELL, F.H.A. 1979. Stratigraphy and sedimentation in the Helikian Elu basin and Hiukitak platform, Bathurst Inlet-Melville Sound, Northwest Territories. Geological Survey of Canada, Paper 79-8.

CAMPBELL, F.H.A., and CECILE, M.P. 1981. Evolution of the Early Proterozoic Kilohigok Basin, Bathurst Inlet - Victoria Island, Northwest Territories. In Proterozoic basins of Canada. Edited by F.H.A. Campbell. Geological Survey of Canada, Paper 81-10, pp. 103-131.

CATY, J.-L. 1976. Region du Lac Mistassini, Quebec, stratigraphie et sedimentologie de la Formation de Papaskwasati. Ministere des Richesses 
Naturelles, Quebec, DPV-423.

CHANDLER, F.W. 1988. The Early Proterozoic Richmond Gulf graben, east coast of Hudson Bay, Quebec. Geological Survey of Canada, Bulletin 363.

CHIARENZELLI, J.R. 1983. Mid-Proterozoic chemical weathering, regolith and silcrete in the Thelon Basin. M.Sc. thesis, Carleton University, Ottawa, Ontario.

CHITTLEBOROUGH, D.J. 1991. Indices of weathering for soils and paleosols formed on silicate rocks. Australian Journal of Earth Sciences, 38: 115-120.

CHOWN, E.H., and CATY, J.-L. 1979. Dolomitized regolith beneath the Albanel Formation Lake Mistassini, Quebec. Geological Association of Canada Mineralogical Association of Canada, Program with Abstracts, 4: 43.

----- 1983. Diagenesis of the Aphebian Mistassini regolith, Quebec, Canada. Precambrian Research, 19: 285-299.

COETZEE, C.R. 1940. Sillimanite-corundum rock: a metamorphosed bauxite in Namaqualand. Transactions of the Royal Society of South Africa, 28: 199-206.

CORKERY, M.T. 1983. GS-7 Cross Lake supracrustal investigation. In Report of 
field activities 1983. Manitoba Department of Energy and Mines, Winnipeg, Manitoba, pp. 32-45.

DASH, B., SAHU, K.N., and BOWES, D.R. 1987. Geochemistry and original nature of Precambrian khondalites in the Eastern Ghats, Orissa, India. Transactions of the Royal Society of Edinburgh: Earth Sciences, 78: 115-127.

DE KEMP, E.A. 1987. Stratigraphy, provenance and geochronology of Archean supracrustal rocks of western Eyapamikama Lake area, northwestern Ontario. M.Sc. thesis, Carleton University, Ottawa, Ontario.

DUFFIN, M.E., LEE, M., KLEIN, G. DE V., and HAY, R.L. 1989. Potassic diagenesis of Cambrian sandstones and Precambrian granitic basement in UPH-3 deep hole, Upper Mississippi Valley, U.S.A. Journal of Sedimentary Petrology, 59: 848-861.

EADE, K.E. 1966. Fort George River and Kaniapiskau River (west half) map areas, New Quebec. Geological Survey of Canada, Memoir 339.

EADE, K.E., and BLAKE, D.H. 1977. Geology of the Tulemalu map- area, District of Keewatin. In Report of activities, part A. Geological Survey of Canada, Paper 77-1A, pp. 209-211. 
ERIKSSON, K.A., and SOEGAARD, K. 1985. The petrography and geochemistry of Archean and early Proterozoic sediments: implications for crustal compositions and surface processes. In Proterozoic exogenic processes and related metallogeny.

Edited by K. Laajoki, and J. Paakkola. Geological Survey of Finland, Bulletin 331, pp. 8-32.

ESTEBAN, M., and KLAPPA, C.F. 1983. Subaerial exposure environments. In Carbonate depositional environments. Edited by P.A. Scholle, D.G. Bebout, and C.H. Moore. American Association of Petroleum Geologists, Memoir 33, pp. 1-54.

FALCK, H. 1990. Volcanic and sedimentary rocks of the Yellowknife Bay Formation, Giant Section, Yellowknife greenstone belt, NWT. M.Sc thesis, Carleton University, Ottawa, Ontario.

FALCK, H., DONALDSON, J.A., and HALL, L. 1991. Regolith beneath the Archean Jackson Lake Formation: its implications for Yellowknife volcanic belt stratigraphy, Slave province, NWT. Geological Association of Canada Mineralogical Association of Canada - Society of Economic Geologists, Program with Abstracts, 16: A35.

FRISCH, T. 1982. Precambrian geology of the Prince Albert Hills, western Melville Peninsula, Northwest Territories. Geological Survey of Canada, Bulletin 
346.

GALL, Q. 1991. Precambrian paleosols in Canada: an overview. Geological Association of Canada - Mineralogical Association of Canada - Society of Economic Geologists, Program with Abstracts, 16: 41A.

------- In press. The early Proterozoic Thelon paleosol as part of the Matonabbee unconformity, northwestern Canadian Shield. In Mineralogical and geochemical records of paleoweathering, IGCP 317. Edited by J.M. Schmitt and Q. Gall. Memoires des Sciences de la Terre, Ecole des Mines de Paris, Special Volume.

GALL, Q., and DONALDSON, J.A. 1990a. The sub-Thelon Formation paleosol, Northwest Territories. In Current research, part C. Geological Survey of Canada, Paper 90-1C, pp. 271-277.

1990b. The sub-Thelon Formation paleosol, and its correlation with similar paleosols in the northwestern part of the Canadian Shield. Geological Association of Canada - Mineralogical Association of Canada, Program with Abstracts, 15: A43.

GAY, A., and GRANDSTAFF, D.E. 1980. Chemistry and mineralogy of Precambrian paleosols at Elliot Lake, Ontario. Precambrian Research, 12: 
349-373.

G-FARROW, C.E., and MOSSMAN, D.J. 1988. Geology of Precambrian paleosols at the base of the Huronian Supergroup, Elliot Lake, Ontario, Canada. Precambrian Research, 42: 107-139.

GILE, L.H., HAWLEY, J.W., and GROSSMAN, R.B. 1981. Soils and geomorphology in the Basin and Range area of southern New Mexico Guidebook to the Desert Project. New Mexico Bureau of Mines and Mineral Resources, Memoir 39.

GILE, L.H., PETERSON, F.F., and GROSSMAN, R.B. 1966. Morphological and genetic sequences of carbonate accumulation in desert soils. Soil Science, 101: $347-360$.

GOLANI, P.R. 1989. Sillimanite-corundum deposits of Sonapahar, Meghalaya, India: a metamorphosed Precambrian paleosol. Precambrian Research, 43: 175-189.

GOLDICH, S.S. 1938. A study of rock weathering. Journal of Geology, 46: 17-60.

GRANT, W.H. 1969. Abrasion pH, an index of weathering. Clays and Clay 
Minerals, 17: 151-155.

GROTZINGER, J.P., MCCORMICK, D.S., and PELECHATY, S.M. 1987.

Progress report on the stratigraphy, sedimentology and significance of the Kimerot and Bear Creek groups, Kilohigok Basin, District of Mackenzie. In Current research, part A. Geological Survey of Canada, Paper 87-1A, pp. 219-238.

GROTZINGER, J.P., ADAMS, R.D., MCCORMICK, D.S., and MYROW, P. 1989. Sequence stratigraphy, correlations between Wopmay Orogen and Kilohigok Basin, and further investigations of the Bear Creek Group (Goulburn Supergroup), District of Mackenzie, N.W.T. In Current research, part C. Geological Survey of Canada, Paper 89-1C, pp. 107-119.

HARNOIS, L. 1988. The CIW index: a new chemical index of weathering. Sedimentary Geology, 55: 319-322.

HARPER, D.A., LONGSTAFFE, F.J., WADLEIGH, M.A., CARTER, T.R., and EASTON, R.M. 1991. Potassic alteration of Precambrian basement rocks in southwestern Ontario. Geological Association of Canada - Mineralogical Association of Canada - Society of Economic Geologists, Program with Abstracts, 16: A51. 
HERD, R.K., CHANDLER, F.W., and ERMANOVICS, I.F. 1976. Weathering of Archean granitoid rocks, Island Lake, Manitoba. Geological Association of Canada - Mineralogical Association of Canada, Program with Abstracts, 1: 72.

HERD, R.K., CURRIE, K.L., and ERMANOVICS, I.F. 1987. Island Lake Manitoba-Ontario. Geological Survey of Canada, Map 1646A, scale 1:250,000.

HOLLAND, H.D., and FEAKES, C.R. 1989. Paleosols and their relevance to Precambrian atmospheric composition: a discussion. Journal of Geology, 97: $761-762$.

HOLLAND, H.D., FEAKES, C.R., and ZBINDEN, E.A. 1989. The Flin Flon paleosol and the composition of the atmosphere 1.8 BYBP. American Journal of Science, 289: 262-289.

JACKSON, G.D., and IANNELLI, T.R. 1981. Rift-related cyclic sedimentation in the Neohelikian Borden Basin, northern Baffin Island. In Proterozoic basins of Canada. Edited by F.H.A. Campbell. Geological Survey of Canada, Paper 81-10, pp. 269-302.

JAMES, N.P., and CHOQUETTE, P.W. 1984. Introduction. In Paleokarst. Edited by N.P. James and P.W. Choquette. Springer-Verlag, New York, pp. 1-21. 
JEFFERSON, C.W. 1983. The Upper Proterozoic Redstone Copper Belt, Mackenzie Mountains, Northwest Territories. Ph.D. thesis, University of Western Ontario, London, Ontario.

JEFFERSON, C.W., and RUELLE, J.C.L. 1986. The Late Proterozoic Redstone Copper Belt, Mackenzie Mountains, Northwest Territories. In Mineral deposits of northern Cordillera. Edited by J.A. Morin. Canadian Institute of Mining and Metallurgy, Special Volume 37, pp. 154-168.

JENNY, H. 1941. Factors of soil formation. McGraw-Hill, New York.

KALLIOKOSKI, J. 1975. Chemistry and mineralogy of Precambrian paleosols in northern Michigan. Geological Society of America Bulletin, 86: 371-376.

KELLER, W.D. 1955. The principles of chemical weathering. Lucas Brothers Publishers, Columbia, Missouri.

KERANS, C., ROSS, G.M., DONALDSON, J.A., and GELDSETZER, H.J. 1981. Tectonism and depositional history of the Helikian Hornby Bay and Dismal Lakes groups, District of Mackenzie. In Proterozoic basins of Canada. Edited by F.H.A. Campbell. Geological Survey of Canada, Paper 81-10, pp. 157-182. 
KIMBERLEY, M.M., and GRANDSTAFF, D.E. 1986. Profiles of elemental concentrations in Precambrian paleosols on basaltic and granitic parent materials. Precambrian Research, 32: 133-154.

KIMBERLEY, M.M., GRANDSTAFF, D.E., and TANAKA, R.T. 1984. Topographic control on Precambrian weathering in the Elliot Lake uranium district, Canada. Journal of the Geological Society of London, 141: 229-233.

KIMBERLEY, M.M., JENSEN, L., GRANDSTAFF, D.E., and FOSTER, R.F. 1985. Archean paleosol: weathered Kinojevis basalt beneath fluvial Timiskaming sandstone. Geological Society of America, Abstracts with Programs, 17: 629.

KNIGHT, I., and MORGAN, W.C. 1977. Stratigraphic subdivision of the Aphebian Ramah Group, northern Labrador. Geological Survey of Canada, Paper $77-15$.

1981. The Aphebian Ramah Group, northern Labrador. In Proterozoic basins of Canada. Edited by F.H.A. Campbell. Geological Survey of Canada, Paper 81-10, pp. 313-330.

LECHEMINANT, A.N., IANNELLI, T.R., ZAITLIN, B., and MILLER, A.R. 1981. Geology of the Tebesjuak Lake map-area, District of Keewatin: a progress 
report. In Current research, part B. Geological Survey of Canada, Paper 81-1B, pp. 113-128.

LEWAN, M.D. 1977. Chemistry and mineralogy of Precambrian paleosols in northern Michigan. Discussion. Geological Society of America Bulletin, 88: $1375-1376$.

MACDONALD, C. 1980. Mineralogy and geochemistry of Precambrian regolith in the Athabasca Basin. M.Sc. thesis, University of Saskatchewan, Saskatoon, Saskatchewan.

MARMO, J.S. In press. The Hokkalampi Formation, a lower Proterozoic paleosol in northern Karelia, eastern Finland. In Early organic evolution implications for mineral and energy resources. Edited by M. Schidlowski, S. Golubic, M.M. Kimberley, D.M. McKirdy, and P.A. Trudinger. Springer-Verlag., Berlin.

MATTHEWS, P.E., and SCHARRER, R.H. 1968. A graded unconformity at the base of the early Precambrian Pongola System. Transactions of the Royal Society of South Africa, 71: 257-271.

MUSTARD, P.S., and DONALDSON, J.A. 1990. Paleokarst breccias, calcretes, silcretes and fault talus breccias at the base of upper Proterozoic "Windermere" 
strata, northern Canadian Cordillera. Journal of Sedimentary Petrology, 60: $525-539$.

NESBITT, H.W., and YOUNG, G.M. 1982. Early Proterozoic climates and plate motions inferred from major element chemistry of lutites. Nature, 299: 715-717.

1984. Prediction of some weathering trends of plutonic and volcanic rocks based on thermodynamic and kinetic considerations. Geochimica et Cosmochimica Acta, 48: 1523-1534.

----- 1989. Formation and diagenesis of weathering profiles. Journal of Geology, 97: $129-147$.

PALMER, J.A., PHILLIPS, G.N., and MCCARTHY, T.S. 1989. Paleosols and their relevance to Precambrian atmospheric composition. Journal of Geology, 97: $77-92$.

PATEL, I.M. 1977. Late Precambrian fossil soil horizon in southern New Brunswick, and its stratigraphic significance. Geological Society of America, Abstracts with Programs, 9: 308 .

PELECHATY, S.M. 1990. Stratigraphy, sedimentology and diagenesis of the 
middle Proterozoic Parry Bay and Kanuyak formations, and intervening subKanuyak unconformity, Elu Basin, Northwest Territories, Canada. M.Sc. thesis, Queen's University, Kingston, Ontario.

PELECHATY, S.M., and JAMES, N.P. 1991. Dolomitized middle Proterozoic calcretes, Bathurst Inlet, Northwest Territories, Canada. Journal of Sedimentary Petrology, 61: 988-1001.

RAINBIRD, R.H. 1980. The geology of an area straddling the Archean-Proterozoic unconformity near Cobalt, Ontario. B.Sc. thesis, Carleton University, Ottawa, Ontario.

RAINBIRD, R.H., NESBITT, H.W., and DONALDSON, J.A. 1990. Formation and diagenesis of a sub-Huronian saprolith: comparison with a modern weathering profile. Journal of Geology, 98: 801-822.

RAY, G.E. 1975. Reconnaissance geological mapping of 74A-15 (E) - 16, and 74H-1, and -2. In Summary of investigations. Edited by J.E. Christopher and R. MacDonald. Saskatchewan Department of Mineral Resources, Regina, Saskatchewan, pp. 13-18.

REICHE, P. 1943. Graphic representation of chemical weathering. Journal of 
Sedimentology, 13: 58-68.

REIMER, T.O. 1986. Alumina-rich rocks from the early Precambrian of the Kaapvaal Craton as indicators of paleosols and as products of other decompositional reactions. Precambrian Research, 32: 155-179.

RETALLACK, G. 1986. The fossil record of soils. In Paleosols their recognition and interpretation. Edited by V.P. Wright. Blackwell Scientific Publications, Oxford, pp. 1-57.

----- 1988. Field recognition of paleosols. In Paleosols and weathering through geologic time: principles and applications. Edited by J. Reinhardt and W.R. Sigleo. Geological Society of America, Special Paper 216, pp. 1-20.

RETALLACK, G., GRANDSTAFF, D., and KIMBERLEY, M. 1984. The promise and problems of Precambrian paleosols. Episodes, 7: 8-12.

ROSS, G.M., and CHIARENZELLI, J.R. 1985. Paleoclimatic significance of widespread Proterozoic silcrete in the Bear and Churchill provinces of the northwestern Canadian Shield. Journal of Sedimentary Petrology, 55: 196-204.

RUXTON, B.P., and BERRY, L. 1957. Weathering of granite and associated 
erosional features in Hong Kong. Geological Society of America Bulletin, 68: 1263-1292.

RYAN, B. 1981. Volcanism, sedimentation, plutonism and Grenvillian deformation in the Helikian basins of central Labrador. In Proterozoic basins of Canada. Edited by F.H.A. Campbell. Geological Survey of Canada, Paper 81-10, pp. 361-378.

SCHAU, M., and HENDERSON, J.R. 1983. Archean chemical weathering at three localities on the Canadian Shield. Precambrian Research, 20: 189-224.

SHARMA, R.P. 1979. Origin of the pyrophyllite-diaspore deposits of the Bundelkhand complex, central India. Mineralium Deposita, 14: 343-352.

SINGER, A. 1988. Illite in aridic soils, desert dusts and desert loess. Sedimentary Geology, 59: 251-259.

SMYTH, W.R. 1976. Geology of the Mugford Group, northern Labrador. In Report of activities, 1975. Edited by B.A. Greene. Newfoundland Department of Mines and Energy, Report 76-1, pp. 72-79.

SMYTH, W.R., and KNIGHT, I. 1978. Correlation of the Aphebian supracrustal 
sequences, Nain province, northern Labrador. In Report of activities for 1977.

Edited by R.V. Gibbons. Government of Newfoundland Department of Mines and Energy, Report 78-1, pp. 59-64.

STANWORTH, C.W., and BADHAM, J.P.N. 1984. Lower Proterozoic red beds, evaporites and secondary sedimentary uranium deposits from the East Arm, Great Slave Lake, Canada. Journal of the Geological Society of London, 141: 235-242.

TREMBLAY, L.P. 1972. Geology of the Beaverlodge mining area, Saskatchewan. Geological Survey of Canada, Memoir 367.

----- 1983. Some chemical aspects of the regolithic and hydrothermal alterations associated with the uranium mineralization in the Athabasca Basin, Saskatchewan. In Current research, part A. Geological Survey of Canada, Paper 83-1A, pp. 1-14.

VOGEL, D.E. 1975. Precambrian weathering in acid metavolcanic rocks from the Superior province, Villebon Township, south- central Quebec. Canadian Journal of Earth Sciences, 12: 2080- 2085.

WIGGERING, H., and BEUKES, N.J. 1990. Petrography and geochemistry of a 2000-2200-Ma-old hematitic paleo-alteration profile on Ongeluk basalt of the Transvaal Supergroup, Griqualand West, South Africa. Precambrian Research, 46: 
241-258.

WILKS, M.E., and NISBET, E.G. 1988. Stratigraphy of the Steep Rock Group, northwest Ontario: a major Archean unconformity and Archean stromatolites.

Canadian Journal of Earth Sciences, 25: 370-391. 


\section{CAPTION}

Fig. 1.1. Spatial and temporal distribution of Precambrian paleosols in Canada. Numbered paleosols are marked beside the time scale in columns depending on whether their age of development is well known (on time line), moderately well constrained (?) or poorly constrained (??). 


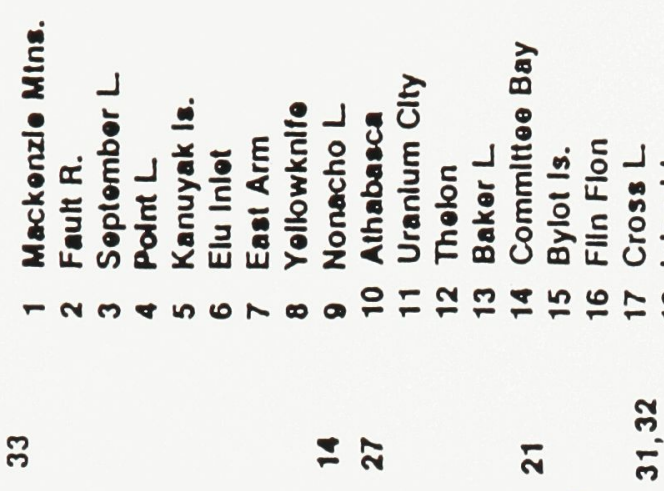
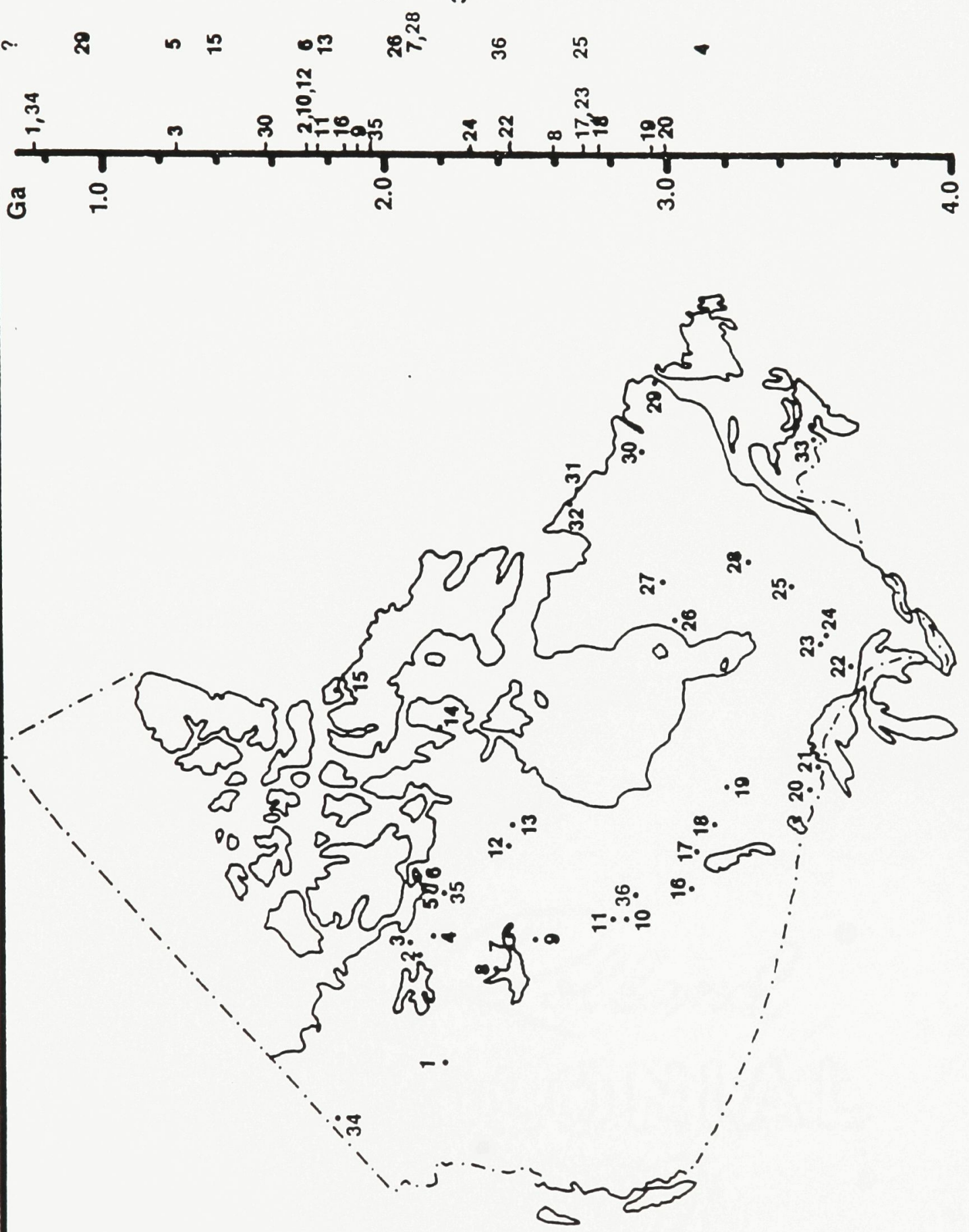
Table 1.1. Metamorphic mineral assemblages of five non-Canadian examples of metamorphosed Precambrian paleosols. Paleosol protoliths indicated in parentheses.

\begin{tabular}{|c|c|c|}
\hline Metamorphic minerals & Comments & Reference \\
\hline $\begin{array}{l}\text { Pyrophyllite and (or) } \\
\text { diaspore }+/ \text { - muscovite } \\
+/ \text { - kaolinite }\end{array}$ & $\begin{array}{l}\text { Metalaterites } \\
\text { (granite anetexites) }\end{array}$ & Sharma (1979) \\
\hline $\begin{array}{l}\text { Sillimanite }+/ \text { - corundum, } \\
\text { sillimanite - quartz }\end{array}$ & Metabauxite & Golani (1989) \\
\hline $\begin{array}{l}\text { Quartz - sillimanite - } \\
\text { garnet }+/ \text { - K-feldspar } \\
+/ \text { - biotite }\end{array}$ & $\begin{array}{l}\text { Kondalites } \\
\text { (granodioritic - } \\
\text { tonalitic) }\end{array}$ & $\begin{array}{l}\text { Dash et al. } \\
\text { (1987) }\end{array}$ \\
\hline $\begin{array}{l}\text { Sillimanite - corundum - } \\
\text { ilmenite }\end{array}$ & $\begin{array}{l}\text { Metabauxite } \\
\text { (granite - gneiss) }\end{array}$ & Coetzee (1940) \\
\hline $\begin{array}{l}\text { Andalusite and (or) kyanite } \\
\text { - chloritoid - muscovite }\end{array}$ & $\begin{array}{l}\text { Oxisol } \\
\text { (siliciclastic } \\
\text { rocks) }\end{array}$ & Marmo (1992) \\
\hline
\end{tabular}




\section{CHAPTER TWO}

SECTION ONE

THE PROTEROZOIC THELON PALEOSOL, NORTHWEST TERRITORIES, CANADA. 


\section{ABSTRACT}

Gall, Q. The Proterozoic Thelon paleosol, Northwest Territories, Canada.

Beneath the ca. $1.72 \mathrm{Ga}$ Thelon Formation in the northwestern part of the Canadian Shield, an unmetamorphosed and undeformed paleosol is preserved on a variety of lower Proterozoic and Archean protoliths. This paper documents the paleosol, referred to as the Thelon paleosol, in four localities where it developed on leucocratic schist, gneiss and granite. The Thelon paleosol is characterized by these ascending changes from fresh protolith, through paleosol to the base of the overlying Thelon Formation: (a) saprolitic disruption of the protolith, resulting in ped and ferran formation; (b) reddening of the paleosol as a consequence of hematitization; (c) increase in dissolution of feldspar (plagioclase > alkali feldspar), increase in the degree of iron oxidation in biotite, chlorite and garnet, and an increase in the abundance of neoform kaolinite, illite and hematite cement; (d) a loss of $\mathrm{TiO}_{2}$, $\mathrm{Fe}_{2} \mathrm{O}_{3}$ (total), $\mathrm{FeO}, \mathrm{MnO}, \mathrm{MgO}, \mathrm{CaO}, \mathrm{Na}_{2} \mathrm{O}, \mathrm{K}_{2} \mathrm{O}, \mathrm{P}_{2} \mathrm{O}_{5}, \mathrm{U}, \mathrm{Zr}, \mathrm{Rb}, \mathrm{Sr}, \mathrm{Ba} ;$ (e) a gain of $\mathrm{Fe}_{2} \mathrm{O}_{3}$; and (f) an increase in $\mathrm{CIA}$ values. The fabric of the parent material appears to be the only soil-forming factor that locally influenced paleosol development. In comparison to thin profiles developed on massive, relatively impervious protoliths, thick profiles have developed on metamorphic protoliths in which the fabric has allowed deeper penetration of paleoweathering fluids. The behaviour of iron in the profiles, particularly Profile 2 over a granite protolith, and an increase in hematite towards the top of the profiles, suggests that the Thelon paleosol formed under an oxidizing atmosphere. 
Subsequent deposition of quartzose conglomerate and sandstone of the Thelon Formation caused compaction of the Thelon paleosol, and was responsible for the formation of stylocumulate fabric in the paleosol. During diagenesis of the Thelon Formation, the influx of diagenetic fluids into the paleosol produced veinlets of quartz and hematite, a newly recognized microcrystalline hydrated aluminophosphate-sulphate mineral, and widespread pseudomorphs of illite after pedogenic vermiform kaolinite.

\section{Introduction}

Thick homoclinal sequences of siliciclastic to carbonate sedimentary rocks are contained in four lower to middle Proterozoic basins that overlie variably deformed and metamorphosed Lower Proterozoic and Archean rocks in the northwestern part of the Canadian Shield. Fraser et al. (1970) noted many similarities between these sedimentary sequences, now preserved as the Hornby Bay, Elu, Thelon and Athabasca Basins (Fig. 2.1.1A), and suggested that they are erosional remnants of a more extensive cratonic sedimentary cover, now thought to have buried the Lower Proterozoic Matonabbee erosional surface (Gall, 1991, 1992). The Matonabbee unconformity is a term applied to the basal unconformity beneath the Hornby Bay, Elu, Thelon and Athabasca basins which, based on geochronologic and stratigraphic evidence, developed over a wide area of the northwestern Canadian Shield during the Early Proterozoic. Preserved beneath the basin sequences, as part of the 
Matonabbee unconformity, are spectacular examples of a Precambrian paleosol which is essentially undeformed and unmetamorphosed.

The Thelon Basin (Fig. 2.1.1B) is an extensive intracratonic depression filled primarily with quartz arenite and minor basal conglomerate of the Thelon Formation, which is overlain by areally less-extensive "basalt" of the Kuungmi Formation and stromatolitic dolostones of the Lookout Point Formation. These three units together constitute the lower to middle Proterozoic Barrensland Group (Gall et al., 1992). The Thelon Formation overlies variably paleoweathered sedimentary, volcanic and plutonic rocks of the ca. 1.76 Ga Pitz Formation (Wharton Group), various volcanic, plutonic and sedimentary rocks of the ca. 1.86 Ga Baker Lake Group within the Baker Lake Basin, and unnamed Archean and lower Proterozoic igneous and metamorphic rocks (Miller and LeCheminant, 1985; Patterson and LeCheminant, 1985; Gall et al., 1992).

The paleosol, herein referred to as the Thelon paleosol, appears to be laterally extensive under much of the Thelon Basin. Paleosol profiles have been intersected by drilling in widely separated areas, and crop out in many places along the periphery of the basin. The Thelon paleosol is developed on a wide variety of protoliths including: psammitic to pelitic gneiss and schist, granite, rhyolite, and peridotite. Profile thicknesses range from $100 \mathrm{~m}$ or more in schistose rocks to a few metres in massive granite. A maximum age for the paleoweathering is given by a 
$1748 \mathrm{Ma}$ U-Pb zircon age (T.D. Peterson, pers. comm. 1991) from rapikivi granite of the Pitz Formation, which has been paleoweathered (Gall and Donaldson, 1990). A minimum age for paleosol formation of $1720+/-6$ Ma derives from U-Pb analysis of fluorapatite cement from the basal sandstone and conglomerate of the Thelon Formation (Miller et al., 1989). This paper describes the Thelon paleosol at four localities (Fig. 2.1.1B) beneath the Thelon Formation, where it is developed on leucocratic metamorphic and igneous protoliths of Archean and Early Proterozoic age.

Analytical methods

Major element oxide and trace element analyses of samples from the four profiles were obtained using X-ray fluorescence spectrometry and an automated Philips PW 1410 spectrometer, and samples fused with lithium tetraborate and lithium carbonate. Data reduction was completed by the method of De Jongh (1973). Ferrous iron was analyzed by a modified Wilson cold acid digestion method, using metavanadate titration (Wipple, 1974).

Minerals in the profiles were identified by standard petrographic techniques; and by X-ray diffractometry (XRD). XRD was carried out using a Philips PW 1730 generator and PW 1050 diffractometer control, operating at $40 \mathrm{kV} 40 \mathrm{~mA}$ and using $\mathrm{CuK} \alpha$ radiation. The $<2 \mu \mathrm{m}$ fraction from each sample was separated using settling techniques, concentrated by centrifuge and mounted on a glass slide. Diffractograms 
were produced using separate aliquots of the $<2 \mu \mathrm{m}$ fraction of each untreated sample, the first was heated to $550^{\circ} \mathrm{C}$ to distinguish chlorite from kaolinite, another was glycolated to identify swelling phyllosilicates. A Cambridge Microscan 5 electron microprobe, operating at $20 \mathrm{kV}$ with a 9.0 nanoampere specimen current, was used to identify carbonate and phosphate species. The microprobe is linked to an energydispersive system comprising an Ortec detector and amplifier with a PC-based multichannel analyzer card. Data reduction was completed on a PC using the EDDI program of Pringle (1989).

Most elements are mobile within the weathering zone, even $\mathrm{Al}$, Ti and $\mathrm{Zr}$ (Keller, 1978; Gardner, 1980), which traditionally have been considered immobile (Goldich, 1938; Birkeland, 1974). Inspection of the major element oxide analyses for samples from the Thelon paleosol shows that aluminum was slightly mobile within the paleoweathering profiles, although it was relatively immobile in comparison to all other major elements. Aluminum has therefore been considered stable when calculating concentration ratios. Element losses and gains in the four profiles cannot be quantified, because this would require no change in the volume of the paleoweathering zone, an assumption that would appear unlikely, given that the paleosol was probably buried by up to two kilometres of Proterozoic sediments in some areas of the basin (Overton, 1971), and that compaction-induced stylocumulates have been identified in the profiles (Gall and Donaldson, 1990). However, element losses and gains have been assessed qualitatively by assuming that aluminum was 
essentially immobile, and plotting ratios of elements against aluminum using the concentration ratio $(C R)$ of Gay and Grandstaff $(1980)(C R=(M$ weathered $/ M$ parent $) /\left(\mathrm{Al}_{2} \mathrm{O}_{3}\right.$ weathered $/ \mathrm{Al}_{2} \mathrm{O}_{3}$ parent $)$ where $\mathrm{M}$ is the oxide concentration in the weathered or parent material). In this scheme, concentration ratio values less than one reflect losses, and values greater than one reflect gains, relative to aluminum $(=1)$.

The chemical index of alteration (CIA; Nesbitt and Young, 1982) has also been calculated for all samples. This index uses molecular proportions to measure the degree of $\mathrm{Na}_{2} \mathrm{O}, \mathrm{K}_{2} \mathrm{O}$ and $\mathrm{CaO}$ leaching during weathering relative to $\mathrm{Al}_{2} \mathrm{O}_{3}$. An increase in the CIA value reflects a decrease in $\mathrm{Na}_{2} \mathrm{O}, \mathrm{K}_{2} \mathrm{O}$ and $\mathrm{CaO}$ content with increased weathering.

Results

\section{Profile 1}

This paleoweathering profile developed on an undated protolith of granitoid augen gneiss, between Marjorie and Aberdeen lakes in the Marjorie Hills. Samples were collected a few metres apart along a transect perpendicular to the unconformity. The mineral assemblage of the protolith is plagioclase, potassic feldspar, quartz, hornblende, biotite, zircon and apatite. The feldspars form augen surrounded by small quartz crystals, polycrystalline 'ribbon' quartz, and lesser amounts of other minerals. 
Concurrent with progressive increase in weathering towards the contact with the overlying Thelon Formation, the feldspars in the protolith lose their augen shape and twinning, and become illitized. Authigenic kaolinite appears to have formed on the feldspars before fibrous illite, but subsequent hematitization has rendered resolution of these relationships in thin section difficult. Chlorite near the base of the paleosol is a retrograde pedogenic mineral after biotite and hornblende.

Hematite is pervasive in the paleosol, and typically is concentrated along the gneissosity. Veinlets of microcrystalline quartz and hematite cut the remnant protolith and alteration minerals.

The Thelon Formation overlying Profile 1 is a subarkosic sandstone that contains monocrystalline and polycrystalline quartz grains, feldspar grains and hematitic siltstone, arkose, and metamorphic rock fragments. In order of paragenesis, the interstitial components are quartz cement (locally chalcedony), kaolinite, minor illite and fluorapatite, and hematite.

Figures $2.1 .2 \mathrm{~A}$ to $2.1 .2 \mathrm{~F}$ shows the concentration ratio trends for Profile 1 , derived from XRF analyses (Table 2.1.1). In general, $\mathrm{SiO}_{2}, \mathrm{Fe}_{2} \mathrm{O}_{3}, \mathrm{Cr}$ and $\mathrm{U}$ show an ascending increase, whereas all other oxides and trace elements show an ascending decrease within the paleosol compared to the protolith. In samples 10 and $8, \mathrm{Fe}_{2} \mathrm{O}_{3}$ and $\mathrm{FeO}$ respectively decrease and increase within the paleosol. A profile depicting the $\mathrm{CIA}$ is shown in Figure 2.1.3. The CIA for Profile 1 increases upward 
to the base of the Thelon Formation (Fig. 2.1.3), reflecting increased weathering in the paleosol profile. Sample 2, a sandstone from the overlying Thelon Formation, shows a decrease in CIA.

\section{Profile 2}

The second profile is from a plateau $8 \mathrm{~km}$ northwest of Dubawnt Lake, where paleosol, approximately $4 \mathrm{~m}$ thick, is developed on megacrystic granite of probable Archean age (Peterson et al., 1989) and is overlain by the Thelon Formation. Samples were collected at $1 \mathrm{~m}$ intervals along a transect perpendicular to the unconformity. The protolith consists of perthitic microcline megacrysts in a matrix of quartz, plagioclase, large ragged biotite flakes, and accessory zircon, apatite and magnetite.

During weathering of the granite, the feldspar was illitized, whereas biotite was chloritized and hematitized, especially along cleavage planes (Fig. 2.1.4). Some quartz and feldspar grain boundaries were also corroded. Paragenetically, kaolinite preceded illite, which formed on both kaolinite and feldspar. Hematite cement overprints all remnant protolith minerals as well as the kaolinite and illite (Fig. 2.1.5) and chlorite. Locally developed stylocumulates are defined by hematite-rich serrate laminae which disrupt protolith grains (Fig. 2.1.6).

The basal part of the overlying Thelon Formation consists of poorly sorted 
pebble- to granule-conglomerate and pebbly sandstone. The main clast types are microcrystalline quartz, and granitic, volcanic and metamorphic rock fragments. The volcanic rock fragments (mainly of Pitz Formation) are abundant and typically hematitic. Interstitial minerals are restricted to cherty and microcrystalline quartz cement, and kaolinite (Fig. 2.1.7). The quartz cement predates the coarse, bladed kaolinite. The bladed morphology of the kaolinite is unusual; however, electron microprobe analyses suggest a consistent kandite-group composition. Kaolinite identification was confirmed by X-ray diffractometry using a Gandolphy camera and infrared spectral analyses. Compared to the underlying paleosol, hematite cement is relatively minor in the Thelon Formation, where it rims sparse pores in the quartz cement.

Clay-fraction X-ray diffractograms of Profile 2 samples indicate that kaolinite is present in both the paleosol and the Thelon Formation. Hematite peaks only occur in diffractograms of samples from the top of the paleosol. Illite was identified in paleosol samples in Profile 2, but not in the Thelon Formation samples.

The major oxide and trace element XRF analyses for Profile 2 samples are shown in Table 2.1.1. The concentration ratios for Profile 2 samples are shown in Figs. 2.1.8A to 2.1.8F. Figure 2.1.3 shows the CIA trend for samples from Profile 2; the Archean megacrystic granite protolith is represented by samples 6 and 7 . Profile 2 shows an increase in $\mathrm{Fe}_{2} \mathrm{O}_{3}$ in the paleosol compared to the protolith. Similar to 


$$
2-1-11
$$

the trend seen in Profile 1 , the ascending increase in $\mathrm{Fe}_{2} \mathrm{O}_{3}$ reflects increasing paleosol hematitization. Other major oxides and trace elements in the paleosol either decrease ( $\mathrm{MnO}, \mathrm{FeO}, \mathrm{MgO}, \mathrm{CaO}, \mathrm{Na}_{2} \mathrm{O}, \mathrm{K}_{2} \mathrm{O}, \mathrm{Ba}, \mathrm{Rb}, \mathrm{Cr}$ ), or remain essentially constant $\left(\mathrm{SiO}_{2}, \mathrm{TiO}_{2}, \mathrm{Fe}_{2} \mathrm{O}_{3}\right.$ (total), $\mathrm{U}, \mathrm{Zr}$ ), compared to the protolith. $\mathrm{P}_{2} \mathrm{O}_{5}$ and $\mathrm{Sr}$ show a similar depletion lower in the paleosol, but an increase in the upper part of the paleosol.

\section{Profile 3}

Profile 3 samples were collected from drill core (DH BL-83-15). This drill hole, part of the Boomerang Lake grid, was drilled by Urangesellschaft Canada Ltd. to test an EM conductor for uranium mineralization (Davidson and Gandhi, 1989). DH BL-83-15 did not intersect unconformity-related uranium mineralization, despite being only $200 \mathrm{~m}$ from DH BL-83-21, which did intersect unconformity-related uranium mineralization. However, below the Thelon sediments, BL-83-15 does exhibit transitional changes in mineralogy, textures and geochemistry above a protolith of pelitic gneiss, indicating that the Thelon paleosol was intersected during drilling. In Profile 3, the pelitic gneiss displays a colour change from medium grey in the fresh protolith to pinkish grey towards the top of the paleosol, primarily due to increasing amounts of hematitization. As the unconformity with the overlying Thelon Formation is approached, the paleosol profile shows an increase in clay minerals, as well as a breakdown of the original metamorphic fabric. 
The gneiss protolith in Profile 3 consists of medium-grained ( $3 \mathrm{~mm}$ average) biotite- and garnet-bearing quartzo-feldspathic gneiss, containing minor amounts of hornblende, muscovite, zircon and rutile. Almandine garnets form porphyroblasts up to $5 \mathrm{~mm}$ in diameter. The feldspars are primarily potassic; plagioclase feldspar is less abundant but invariably present.

Incipient weathering of anhedral microcline is evident in protolith, 33 m below the unconformity, where kaolinite and illite follow relict grid-iron twin planes, and on biotite, which is commonly altered to chlorite or has been hematitized along cleavage planes. Paleosol samples higher in the profile display increasing amounts of feldspar dissolution, illite growth, and hematite cementation. Garnet porphyroblasts containing numerous anhedral quartz and feldspar inclusions have been altered to hematite. Some inclusions have been replaced by kaolinite (now partly illitized), a vermiculite- or chlorite-type phyllosilicate, and hematite (Fig. 2.1.9). Garnets in two samples contain minor authigenic dolomite cement; the dolomite cement also cuts metamorphic grain boundaries and masks the kaolinite and illite, but appears to pre-date hematitization. Zircon grains are fractured and hematitized. Flakes of graphite have grown across grain boundaries, as well as across the hematite cement, and are clearly post-weathering. This graphite, not seen in other profiles, may be related to the epigenetic unconformity-related uranium and gold mineralization in the area. 
In Profile 3 the Thelon Formation consists of pinkish to yellowish grey arkosic fine- to medium-grained sandstone. The main clast types are subrounded quartz, potassic feldspar, rock fragments (including ones of pedogenic origin) and minor biotite, chlorite, zircon and tourmaline. Quartz overgrowths tend to be separated from the grains by thin dust rims. Interstitial authigenic clay-size minerals include vermiform kaolinite, fibrous and randomly oriented illite, some of which is pseudomorphous after kaolinite (Fig. 2.1.10), and minor fibrous chlorite that is interstitial as well as an alteration product of detrital biotite and rock fragments. A microcrystalline hydrated alumino-phosphate-sulphate mineral (APS) (see Chapter Three, Section One, for a detailed description of the APS) also occurs as micron-size crystals on interstitial illitized kaolinite. Finely disseminated hematite forms a minor cement along grain boundaries and between grains where it cements authigenic clay minerals. Late microfractures and rare stylocumulates are also lined by hematite.

Trends of concentration ratios for Profile 3 samples (Figs. 2.1.11A to 2.1.11F), calculated from XRF analyses of the samples (Table 2.1.1), indicate that both $\mathrm{Na}_{2} \mathrm{O}$ and $\mathrm{Sr}$ tend to increase upward within the paleosol. One explanation for this may be that both $\mathrm{Na}$ and $\mathrm{Sr}$ reside within albitic plagioclase, which was apparently more resistant to weathering. As well, Sr trends in this profile may be linked to the presence of the APS mineral. $\mathrm{TiO}_{2}, \mathrm{Fe}_{2} \mathrm{O}_{3}$ (total), $\mathrm{FeO}, \mathrm{CaO}$, and $\mathrm{Rb}$ decrease in the paleosol in comparison to the deepest core samples of the gneissic protolith. The other elements generally fluctuate, rather than displaying clear ascending increases 
or decreases. CIA values also increase within the paleosol (Fig. 2.1.3).

\section{Profile 4}

In 1983, Urangesellschaft Canada Ltd. drilled an EM anomaly in what is known as the Queen Bess grid, a few kilometres south of Schultz Lake. Profile 4 was sampled from drill core (QB-2) over an interval where colour and mineralogical changes in the core suggested that drilling had intersected the Thelon paleosol. In drill core, the approximately 59 feet thick paleosol shows a red hematitic upper zone grading downwards into a reddish-brown hematite- and illite-rich zone, and then into a greenish-black to grey chlorite and biotite schist near the bottom of the hole.

The paleosol protolith is a semipelitic schist of uniform grain size (average $=$ $1 \mathrm{~mm}$ diam.). Schistosity is defined by aligned blades of biotite and muscovite, and subtle elongation of anhedral quartz and potassic feldspar grains. Subordinate components include quartz-feldspar augen, garnet porphyroblasts, andalusite porphyroblasts, apatite and zircon. The augen appear to be deformed, arkosic rock fragments.

Within the paleosol, kaolinite is present as interstitial blocky and vermiform booklets. In some samples the kaolinite has grown within or immediately adjacent to alkali feldspar grains (Fig. 2.1.12). Unoriented growths of fibrous and rosette illite occur as bundled or matted matrix, as grain coatings on the borders of corroded 
feldspar (and other) grains, and as pseudomorphs after kaolinite. Chlorite is evident near the base of the profiles where it has formed partial pseudomorphs of metamorphic biotite, or has formed discrete fibres. A few samples contain extremely fine-grained intergrowths of chlorite and illite; but no mixed-layer phyllosilicates have been detected on X-ray diffractograms. Samples from the top of the paleosol contain euhedral APS crystals which cut the phyllosilicates. Blocky dolomite cement in millimetre-scale, irregularly shaped patches is a minor component of some paleosol samples. The dolomite is disseminated, commonly in association with altered plagioclase grains, and is not visibly related to veining. Narrow veinlets of cherty quartz both cut across and parallel the metamorphic fabric of the protolith.

The Thelon Formation in Profile 4 consists of pale red to reddish-brown interstratified siltstone, paraconglomerate and subordinate sandstone. The siltstone and sandstone contain monocrystalline and polycrystalline quartz clasts and abundant detrital white micas. Conglomerate clast types include granite, hematitized siltstone, and both polycrystalline and monocrystalline quartz of probable vein, volcanic and metamorphic origin. The conglomerate also contains a few kaolinite- and illitebearing schistose clasts which may have a pedogenic origin. Diagenetic matrix components within the sandstone and siltstone include minor cherty quartz cement, vermiform kaolinite (which commonly fills interstitial spaces), fibrous rosette illite that locally pseudomorphs the kaolinite, minor fibrous chlorite, and late-stage hematite cement. A few samples contain diagenetic fluorapatite and the APS 
mineral, which formed after the phyllosilicate minerals, but before hematite cementation.

Chemical analyses (Table 2.1.1) and concentration ratios (Figs. 2.1.13A to 2.1.13F) for Profile 4 samples indicate that, compared to the least-weathered protolith, there is an ascending increase in $\mathrm{Fe}_{2} \mathrm{O}_{3}, \mathrm{P}_{2} \mathrm{O}_{5}$, $\mathrm{Sr}$ and in the CIA value (Fig. 2.1.3). There is an ascending decrease in $\mathrm{FeO}, \mathrm{MnO}, \mathrm{MgO}, \mathrm{CaO}, \mathrm{K}_{2} \mathrm{O}$ and $\mathrm{U}$, as more extensively paleoweathered schist is encountered. $\mathrm{SiO}_{2}, \mathrm{TiO}_{2}, \mathrm{Fe}_{2} \mathrm{O}_{3}$ (total), $\mathrm{Na}_{2} \mathrm{O}, \mathrm{Cr}, \mathrm{Zr}, \mathrm{Rb}$ and $\mathrm{Ba}$ remain essentially constant.

\section{Discussion}

Developed on gneiss, schist, and granite, all four paleoweathering profiles display similar textural, mineralogical and geochemical trends. Upward through the paleosol profiles, the metamorphic and megacrystic textures of the protoliths show increasing disruption in response to dissolution and replacement of the minerals, particularly the feldspars (plagioclase more so than potassic feldspar). In a few localities, the augen gneiss and granite display millimetre- to centimetre-scale patches of less weathered minerals surrounded by more altered, hematite-rich areas; these are perhaps akin to ped and ferran structures recognized in younger paleosols (e.g., Brewer and Sleeman, 1960; Retallack, 1988). 
paleosol is inferred to reflect leaching by meteoric fluids during paleoweathering. Generally, the extent to which different minerals have been altered, and the subsequent depletion of most elements in the Thelon paleosol, is similar to mineral alteration and element trends developed in younger weathering profiles (e.g., Goldich, 1938; Colman, 1982). The consistent increase in ferric iron towards the top of the profiles, mirroring a decrease in ferrous iron, reflects the redox transformation of iron in ferromagnesian minerals, and hematite cementation during oxidation of the paleosol, prior to deposition of the Thelon Formation.

In Profile 1, increase in $\mathrm{SiO}_{2}$ may be interpreted as a residual effect due to the removal of most other elements. However, $\mathrm{SiO}_{2}$ does not show an increase within the other profiles, which also experienced a loss of most other elements, and thus the $\mathrm{SiO}_{2}$ increase may be due to the inclusion of quartz veinlets in the analyzed samples. The greater abundance of $\mathrm{SiO}_{2}$ in the Thelon Formation reflects silica enrichment due to diagenetic quartz cement, as well as compositional maturity of the framework grains.

The ubiquitous dissolution of plagioclase feldspar, and, to a lesser extent, potassic feldspars, can account for the general depletion of calcium and potassium, and to a lesser extent sodium, in the profiles. However, the geochemical profiles do not indicate that potassium feldspars $\left(\mathrm{K}_{2} \mathrm{O}\right.$ trends) are more weathered than calcium or sodium feldspars ( $\mathrm{CaO}$ and $\mathrm{Na}_{2} \mathrm{O}$ trends), as predicted in theory (Birkeland, 1974; 
Nesbitt et al., 1980) and observed in the field (Goldich, 1938; Blaxland, 1974; Middleburg et al., 1988). Yet, when both types of feldspar coexist in thin section, the plagioclase is invariably more extensively altered to phyllosilicate minerals than the potassic feldspar. The depletion of these elements is also reflected in the CIA trends. Figure 2.1.3 shows that in all the profiles CIA increases (i.e., $\mathrm{Ca}, \mathrm{Na}, \mathrm{K}$ depletion) with increased weathering of the various protoliths. As well, the CIA value for the Thelon Formation is typically high, indicating that the quartzose sediments are geochemically mature and rich in weathering products. Petrographic examination confirms this.

The behaviour of potassium in the paleosol profiles is of particular interest, because many Precambrian paleosols record potassium enrichment, rather than depletion, compared to fresh protolith (e.g., Williams, 1968; Reimer, 1986; Rainbird et al., 1990; Wiggering and Beukes, 1990). One popular explanation for the potassium enrichment is that post-paleoweathering diagenetic and/or metamorphic processes altered the original composition of the paleosol (Holland and Zbinden, 1988; Retallack, 1991). Another possible cause for pedogenic potassium enrichment is the introduction into the weathering profile of aerosolic dust containing potassic aluminosilicates into the weathering profile (Singer, 1988). However, in the Thelon paleosol, the consistent depletion of $\mathrm{K}_{2}$ Osuggest that potassium did not accumulate in these ways, but was readily leached from feldspars and micas during paleoweathering. 
A conundrum exists because, despite the $\mathrm{K}_{2} \mathrm{O}$ depletion in the geochemical profiles, vermiform kaolinite within the Thelon paleosol and immediately overlying Thelon Formation is locally pseudomorphed by illite, implying the addition of potassium to kaolinite to form illite. However, illite pseudomorphs after kaolinite also occur elsewhere within the Thelon Formation, suggesting that illitization of the kaolinite was a diagenetic phenomenon. Eriksson and Soegaard (1985) described illite pseudomorphous after kaolinite from the Fortescue Group conglomerate in Australia, and attributed its occurrence to kaolinite diagenesis by potassium-rich groundwaters. If the illitization of kaolinite in the Thelon paleosol is linked to burial diagenesis within the overlying Thelon Formation, and, as demonstrated, there is general ascending depletion of potassium within the paleosol profiles, then the apparent potassium addition to the paleosol during burial diagenesis was less than the amount of potassium depletion during paleoweathering. Furthermore, one can conclude that, geochemically, the paleosol profiles still reflect the behaviour of potassium during paleoweathering (i.e., leaching and depletion).

The observation that: (a) $\mathrm{K}_{2} \mathrm{O}, \mathrm{Na}_{2} \mathrm{O}$ and $\mathrm{CaO}$ consistently decrease with increase in paleoweathering in the Thelon paleosol; and (b) diagenetic potassium overprinting of the paleosol is not evident from the geochemical analyses, despite the presence of illite pseuodmorphous after kaolinite, can be depicted using A-CN-K ternary plots for the four paleosol profiles (Fig. 2.1.14). The general depletion of alkali and alkaline earth metals is evident in Figure 2.1.14. The plot for Profile 3 
shows only the ascending decrease in $\mathrm{K}_{2} \mathrm{O}$, due to the very low amounts (some below the analytical detection limit) of $\mathrm{Na}_{2} \mathrm{O}$ and $\mathrm{CaO}$ in the fresh and paleoweathered pelitic gneiss protolith. A-CN-K ternary plots have been described by Nesbitt and Young (1984), and used to show the progressive depletion of alkali and alkaline earth elements relative to alumina during weathering of a protolith. Rainbird et al. (1990) have also used such plots to show a relative increase of potassium within the Precambrian Ville Marie paleosol, interpreted to reflect potassium addition to the paleosol during diagenesis of the overlying Lorrain Formation.

The depletion of $\mathrm{TiO}_{2}$ within the paleosol, particularly in Profiles 1 and 3, suggests that titanium was mobile to some degree during paleoweathering. This is in contrast to its general retention in modern soils (Birkeland, 1974). The alteration to hydroxides of plagioclase, biotite, accessory sphene and/or rutile, is one way to mobilize titanium in the weathering environment (Loughnan, 1969; Gardner et al., 1978). Although present in minor amounts, $\mathrm{MgO}$ also exhibits a depletion within most paleosol profiles. The only source for the depleted magnesium appears to be the paleoweathering of igneous and metamorphic biotite or phengite.

The depletion (to the analytical detection limit) of $\mathrm{MnO}$ in Profiles 1, 2 and 4 is surprising considering the generally high oxidation potential of $\mathrm{Mn}$ and the behaviour of $\mathrm{Fe}$ in the profiles. A similar relationship was observed in bauxites of east Malaysia by Wolfenden (1965). This depletion may be explained by a period 
of more chemically reduced and/or intense leaching and manganese mobility in the paleosol, which pre-dated the late stage of paleosol oxidation and hematite cementation. The greater ascending depletion of total iron in Profiles 1 and 3 may be indicative of local intense paleoweathering and/or more reduced conditions, prior to oxidative paleoweathering.

In Profile 1, the slight $\mathrm{Cr}$ increase may be due to the destruction of $\mathrm{Cr}$-bearing spinels or ferromagnesian silicate minerals in the protolith, and subsequent adsorption of $\mathrm{Cr}$ onto ferric hydroxides formed during paleoweathering. Similarly, the increase of uranium in the paleosol may have been due to illuvial uranium, originally adsorbed onto iron oxides, iron hydroxides, and phyllosilicates. Similar uranium trends in the sub-Athabasca Group paleosol in Saskatchewan have been attributed to illuviation under lateritic conditions (Pagel, 1991). An increase in uranium-bearing minerals, such as rutile and leucoxene (cf. G.-Farrow and Mossman, 1988), has not been observed within the paleosol.

Of the five soil forming factors defined by Jenny (1941) (biologic, topographic, time, climate, and parent material), there is only evidence that parent material (protolith) may have influenced the formation of the Thelon paleosol (Gall, 1992a). Thick (decametres) paleosol profiles have developed on metamorphosed protoliths, whereas thinner (metres) paleosol profiles have developed on more massive, homogeneous protoliths, such as the granite in Profile 2. 
By assuming a lack of life processes in Precambrian soils, paleosols have been useed to gauge the evolution of free oxygen in Earth's early atmosphere, primarily by investigating the behaviour of iron in the paleosol (Frarey and Roscoe, 1970; Holland, 1984). Holland (1984) and Holland and Zbinden (1988) have shown that, prior to approximately $1.8 \mathrm{Ga}$, reduced paleosols formed on rocks with high iron content (e.g. basalt) and that iron was lost from these paleosols, while oxidized paleosols formed on rocks with low iron contents (e.g. granite) and that little iron was removed by weathering. They reasoned that rocks with abundant iron would demand more oxygen than was available in order to produce an oxidized paleosol. Using the ratio of the oxidant demand to acid demand needed to weather a protolith $\left(\mathrm{R}=0.2 \mathrm{M}_{\mathrm{FeO}}+0.5 \mathrm{M}_{\mathrm{MnO}}+3.75 \mathrm{M}_{\mathrm{FeS} 2}+\mathrm{M}_{\mathrm{C}} / 2\left(\mathrm{M}_{\mathrm{CaO}}+\mathrm{M}_{\mathrm{MgO}}+\mathrm{M}_{\mathrm{Na} 2 \mathrm{O}}+\mathrm{M}_{\mathrm{K} 2 \mathrm{O}}\right)-\right.$ $\mathrm{M}_{\mathrm{C}}-4 \mathrm{M}_{\mathrm{FeS2}}$ (Holland, 1984)), Holland and Zbinden (1988) and Pinto and Holland (1988) suggested that, between 2.5 and $1.8 \mathrm{Ga}$, the transition between low $\mathrm{R}$ value protoliths with oxidized paleosols and little iron loss, and high $\mathrm{R}$ value protoliths with reduced paleosols and iron loss, occurred at an $\mathrm{R}$ value of approximately 0.03 ; and, that the range of $\mathrm{pO}_{2}$ in the atmosphere was between $5 \times 10^{-4}$ and $1 \times 10^{-3}$ atm. A study of the ca. 1.8 Ga Flin Flon paleosol in Manitoba (Holland and Zbinden, 1988; Holland et al., 1989), revealed that even a basaltic protolith with high $\mathrm{R}$ values $(0.08$ to 0.10 ) could produce a paleosol where much of the iron is oxidized and little is lost. Further studies are needed to determine if there was a rapid increase in the oxygen content of Earth's atmosphere after approximately $1.8 \mathrm{Ga}$, as suggested by the Flin Flon paleosol, or whether there was a more gradual oxygenation of the atmosphere, 
as suggested by a lower-sloping redox threshold curve depicted by Retallack (1992, Fig. 16.6).

The $\mathrm{R}$ values for the unweathered protoliths in the four Thelon paleosol profiles were calculated using average oxide weight percent (Table 2.1.1), and without consideration of elemental carbon and sulphur, because they are absent in the samples from the four profiles. The $\mathrm{R}$ value and extent of iron loss during weathering for the three metamorphic protoliths (Table 2.1.2) are comparable to results reported for weathered metapelites and semimetapelites beneath the Athabasca Basin in northern Saskatchewan (Holland, 1984). The sub-Athabasca Basin paleosol formed at approximately the same time as the Thelon paleosol (Gall, 1992), and has been classified as an Oxisol by Retallack (1992). The relatively high amount of iron loss from the Thelon profiles is difficult to explain, considering their moderate to low $\mathrm{R}$ values and the generally oxidized state of the profiles. Perhaps, as Holland (1984) suggested, the compositional heterogeneity of the metamorphic protoliths adds ambiguity to calculating and interpreting $\mathrm{R}$ values and the amount of iron lost during weathering. If the weathering fluids did follow selective, texturally-controlled routes during weathering of the metamorphic protoliths, then chemical heterogeneity would result in the weathering profile, and could lead to ambiguous resuits concerning the behaviour of iron during weathering.

The granite protolith has a higher than average $\mathrm{R}$ value for a granite $(\sim 0.01$, 
Pinto and Holland, 1988). The relatively high $\mathrm{R}$ value for the granite protolith from Profile 2 may be due to its high average FeO content (ave. $3.30 \mathrm{wt} \%$ ), which generally exceeds the $\mathrm{FeO}$ content of other Precambrian granitic protoliths for which R values have been calculated (cf., Grandstaff et al., 1986; G.-Farrow and Mossman, 1988; Rainbird et al., 1990). The texturally and mineralogically homogeneous granite lost little iron (Table 2), suggesting that weathering occurred under an oxidizing atmosphere. Weathering under an oxidizing atmosphere is supported by the increase in ferric iron and hematite towards the top of the Thelon paleosol.

Generally, petrographic relationships suggest that during pedogenesis, illitization and kaolinitization of feldspars, chloritization of biotite, plus interstitial kaolinite and minor dolomite formation, has been succeeded by hematite cementation (Fig. 2.1.15). During subsequent diagenesis in the overlying Thelon Formation, early quartz cementation was followed by kaolinite and minor illite and chlorite formation, then fluorapatite and APS cementation, and finally, hematite cementation (Fig. 2.1.15).

Minor quartz and hematite veinlets in Profiles 1 and 2, and the APS mineral in Profiles 3 and 4, are considered to reflect diagenetic overprinting of the paleosol. This overprinting is reflected in anomalous gains in $\mathrm{SiO}_{2}$ in Profile 1, and $\mathrm{P}_{2} \mathrm{O}_{5}$ and Sr within the top of the paleosol in profiles 2, 3 and 4. The illitization of pedogenic, vermiform kaolinite is also suspected to be a diagenetic phenomenon. Because of 
this evidence of diagenetic overprinting, the possibility that the phyllosilicates in the paleosol were formed during diagenetic overprinting of the paleosol cannot be dismissed. There is little critical textural or chemical evidence to distinguish pedogenic from diagenetic phyllosilicates. For this reason, the line separating paleoweathering and diagenetic phyllosilicates in Figure 2.1.15 has been dashed. The subhorizontal stylocumulates of hematite and phyllosilicate in Profile 2 are considered to represent physico-chemical accumulations formed during compaction of the paleosol, probably during deposition of sediments of the overlying Thelon Formation (Gall and Donaldson, 1990).

Summary and conclusions

Several general conclusions can be drawn about the Thelon paleosol which developed at the ca. $1.74 \mathrm{Ga}$ Matonabbee unconformity, prior to burial by the Thelon Formation. Paleosol profiles developed in metasedimentary schist and gneiss are generally thicker than profiles in more massive granite, because the fabrics of the metamorphic protoliths permitted deeper penetration of paleoweathering fluids. Structural and textural disruption of the paleosol is locally evident, but elsewhere erosion appears to have left paleosol profiles in which only the chemical imprint of paleoweathering persists.

Paleoweathering also produced a vertical colour zonation which reflects mineralogical changes. The metasedimentary and granite protoliths show an 
ascending colour transition from fresh protolith, to green-grey (chlorite- and illiterich) basal paleosol, to reddened (hematitic) upper paleosol. Petrographic relationships suggest that kaolinite, illite, chlorite, minor dolomite and hematite formed successively during paleoweathering.

Assuming relative aluminum immobility, ferric iron has generally increased, whereas most other elements (including $\mathrm{Zr}$ and $\mathrm{Ti}$ in some profiles) are depleted in the paleosol compared to the protoliths. CIA values also show a consistent ascending increase within the paleosol profiles, reflecting increased leaching of alkali and alkaline earth elements toward the top of the paleosol. The CIA values in the overlying Thelon Formation are typically high, due to provenance from a thoroughly weathered source. The retention of iron in Profile 2 where the paleosol developed on a compositionally and texturally homogeneous granite, and the increase in ferric iron and hematite towards the top of the paleosol, suggest that the Thelon paleosol formed under an oxidizing atmosphere.

Basal quartz-rich sedimentary rocks of the overlying Thelon Formation contain lithic grains of pedogenic origin, supplying further evidence that weathering of a variety of protoliths occurred before deposition of the Thelon Formation. Diagenesis within the Thelon Formation subsequently began with silica cementation, and continued with kaolinite formation and minor amounts of illite, chlorite, fluorapatite, APS, and hematite, respectively. Due to the presence of veinlets containing quartz 
and hematite, illitization of kaolinite, and some anomalous element gains at the top of the paleosol (e.g., $\mathrm{SiO}_{2}, \mathrm{P}_{2} \mathrm{O}_{5}, \mathrm{Sr}$ ), some diagenetic fluids must have penetrated into the top of the paleosol during diagenesis of the Thelon Formation. Despite diagenetic illitization of kaolinite, there is no anomalous $\mathrm{K}_{2}$ Ogain within the Thelon paleosol. Potassium loss during paleoweathering must have been greater than potassium influx during diagenetic overprinting of the paleosol.

\section{Acknowledgements}

I wish to thank Dr. H. Kodama (Agriculture Canada) for continued advise on matters of clay mineralogy and the use of an infrared spectrometer and laboratory space. Electron microprobe and SEM-EDX analyses were made by $\mathrm{P}$. Jones (Carleton University), and XRF analyses were made by R. Hartree (Ottawa University). Critical review of an earlier version of this paper by J.A. Donaldson (Carleton University), R.H. Rainbird and D.F. Sangster (Geological Survey of Canada) is appreciated. Study of the Thelon paleosol was financially supported by the Natural Science and Engineering Research Council of Canada (operating grant to J.A. Donaldson) and the Department of Indian Affairs and Northern Development (Northern Training Grant to the author). 
References

Blaxland, A.B. 1974. Geochemistry and geochronology of chemical weathering, Butler Hill Granite, Missouri. Geochim. Cosmochim. Acta, 38: 843-852.

Birkeland, P.W. 1974. Pedology, weathering, and geomorphological research. Oxford Univ. Press, New York, 285 pp.

Brewer, R. and Sleeman, J.R. 1960. Soil structure and fabric: their definition and description. J. Soil Sci., 11: 172-185.

Davidson, G.I. and Gandhi, S.S. 1989. Unconformity-related U-Au mineralization in the Middle Proterozoic Thelon sandstone, Boomerang Lake prospect, Northwest Territories, Canada. Economic Geology, v.84, pp. 143-157.

Colman, S.M. 1982. Chemical weathering of basalts and andesites: evidence from weathering rinds. U.S. Geol. Surv., Prof. Pap. 1246, 51 pp.

De Jongh, W.K. 1973. X-ray fluorescence analysis applying theoretical matrix correction. Stainless steel. X-Ray Spectrometry, 2: 151-158.

Eriksson, K.A. and Soegaard, K. 1985. The petrography and geochemistry of Archean and Early Proterozoic sediments: implications for crustal compositions and 
surface processes. In: K. Laajoki and J. Paakkola (Editors), Proterozoic Exogenic Processes and Related Metallogeny. Geol. Surv. Finland, Bull. 311: pp. 9-32.

Frarey, M.J. and Roscoe, S.M. 1970. The Huronian Supergroup north of Lake Huron. In: A.J. Baer (Editor), Symposium on Basins and Geosynclines of the Canadian Shield. Geol. Surv. Canada, Paper 70-40: pp. 143-157.

Fraser, J.A., Donaldson, J.A., Fahrig, W.F. and Tremblay, L.P. 1970. Helikian basins and geosynclines of the northwest Canadian Shield. In: A.J. Baer (Editor), Basins and Geosynclines of the Canadian Shield. Geol. Surv. Can., Pap. 70-40: pp. 213-238.

G.-Farrow, C.E. and Mossman, D.J. 1988. Geology of Precambrian paleosols at the base of the Huronian Supergroup, Elliot Lake, Ontario, Canada. Precambrian Res., 42: $107-139$.

Gall, Q. 1991. Precambrian paleosols in Canada: an overview. Geol. Ass. Can. Mineral. Ass. Can. Ann. Meeting with Soc. Econ. Geol., Prog. Abstr., 16: A41. 1992. Precambrian paleosols in Canada. Can. J. Earth Sci., 29: 2530-2536.

1992a. The Early Proterozoic Thelon paleosol as part of the Matonabbee unconformity in the northwestern Canadian Shield. In: J.M. Schmitt and Q. Gall 


$$
2-1-30
$$

(Editors), Mineralogical and Geochemical Records of Paleoweathering. Ecole des Mines de Paris, Mem. Sc. de la Terre, 18: pp. 163-174.

Gall, Q. and Donaldson, J.A. 1990. The sub-Thelon Formation paleosol, Northwest Territories. Geol. Sur. Can., Pap. 90-1C: 271-277.

Gall, Q., Peterson, T.D. and Donaldson, J.A. 1992. A proposed revision of Early Proterozoic stratigraphy of the Thelon and Baker Lake basins, Northwest Territories. Geol. Sur. Can., Pap. 92-1C: 129-137.

Gardner, L.R. 1980. Mobilization of $\mathrm{Al}$ and Ti during weathering- isovolumetric geochemical evidence. Chem. Geol., 30: 151-165.

Gardner, L.R., Kheoruenromme, I. and Chen, H.S. 1978. Isovolumetric geochemical investigation of a buried granite saprolite near Columbia, SC, U.S.A. Geochim. Cosmochim. Acta, 42: 417-424.

Gay, A.L. and Grandstaff, D.E. 1980. Chemistry and mineralogy of Precambrian paleosols at Elliot Lake, Ontario, Canada. Precambrian Res., 12: 349-373.

Grandstaff, D.E., Edelman, M.J., Foster, R.W., Zbinden, E. and Kimberley, M.M. 1986. Chemistry and mineralogy of Precambrian paleosols at the base of the 
Dominion and Pongola Groups. Precambrian Res., 32: 97-131.

Goldich, S.S. 1938. A study in rock-weathering. J. Geol., 46: 17-58.

Holland, H.D. 1984. The chemical evolution of the atmosphere and oceans. Princeton Univ. Press, Princeton, New Jersey, 582 pp.

Holland, H.D., Feakes, C.R. and Zbinden, E.A. 1989. The Flin Flon paleosol and the composition of the atmosphere 1.8 BYBP. Am. J. Sci., 289: 362-389.

Holland, H.D. and Zbinden, E.A. 1988. Paleosols and the evolution of the atmosphere: Part I. In: A. Lerman and M. Meybeck (Editors), Physical and Chemical Weathering in Geochemical Cycles. NATO ASI Inst., Kluwer Academic Pub., Dordrecht, pp. 61-82.

Jenny, H. 1941. Factors of soil formation. McGraw-Hill, New York, 281 pp.

Keller, W.D. 1978. Diaspore recrystallized at low temperature. Am. Mineral., 63: 326329.

Loughnan, F.C. 1969. Chemical weathering of silicate minerals. Elsevier, London, 155 pp. 
Middleburg, J.J., Van der Weijden, C.H. and Woittiez, J.R.W. 1988. Chemical processes affecting the mobility of major, minor and trace elements during weathering of granitic rocks. Chem. Geol., 68: 253-273.

Miller, A.R. and LeCheminant, A.N. 1985. Geology and uranium metallogeny of Proterozoic supracrustal successions, central District of Keewatin, N.W.T. with comparisons to northern Saskatchewan. In: T.I.I. Sibbald and W. Petruk (Editors), Geology of Uranium Deposits. Can. Inst. Min. Metall., Spec. Pap. 32: pp. 167-185.

Miller, A.R., Cumming, G.L. and Krstic, D. 1989. U-Pb, Pb-Pb and K-Ar isotope study of uraniferous phosphate-bearing rocks in the Thelon Formation, Dubawnt Group, Northwest Territories, Canada. Can. J. Earth Sci., 26: 867-880.

Nesbitt, H.W. and Young, G.M. 1982. Early Proterozoic climates and plate motions inferred from major element chemistry of lutites. Nature, 299: 715-717.

-.--- 1984. Prediction of some weathering trends of plutonic and volcanic rocks based on thermodynamic and kinetic considerations. Geochim. Cosmochim. Acta, 48: 15231534.

Nesbitt, H.W., Markovics, G. and Price, R.C. 1980. Chemical processes affecting alkalis and alkaline earths during continental weathering. Geochim. Cosmochim. 
Acta, 44: 1659-1666.

Overton, A. 1971. Seismic survey of the Dubawnt Group. Geol. Surv. Can., Pap. 711A: 58.

Pagel, M. 1991. Lateritization and paleogeography: their role in the genesis of unconformity-type uranium deposits in Saskatchewan, Canada. In: M. Pagel and J.L. Leroy (Editors), Source, Transport and Deposition of Metals. A.A. Balkema, Rotterdam, pp. 331-332.

Patterson, J.G. and LeCheminant, A.N. 1985. A preliminary geological compilation map of the northeastern Barren Grounds, parts of the districts of Keewatin and Franklin (NTS 46, 56, and parts of 47, 57 and 66). Geol. Surv. Can., Open File Map 1138.

Peterson, T.D., LeCheminant, A.N. and Rainbird, R.H. 1989. Preliminary report on the geology of the northwestern Dubawnt Lake area, District of Keewatin, N.W.T. Geol. Sur. Can., Pap. 89-1C: 173-183.

Pinto, J.P. and Holland, H.D. 1988. Paleosols and evolution of the atmosphere; Part II. In: J. Reinhardt and W.R. Sigleo (Editors), Paleosols and Weathering Through Geologic Time: Principles and Applications. Geol. Soc. Am., Spec. Pap. 216: pp. 21- 
34.

Pringle, G.J. 1989. EDDI - A FORTRAN computer program to produce corrected microprobe analyses of minerals using an energy dispersive X-ray spectrometer. Geol. Surv. Can., Open File 2127.

Rainbird, R.H., Nesbitt, H.W. and Donaldson, J.A. 1990. Formation and diagenesis of a sub-Huronian saprolith: comparison with a modern weathering profile. J. Geol., 98: $801-822$.

Reimer, T.O. 1986. Alumina-rich rocks from the early Precambrian of the Kaapvaal Craton as indicators of paleosols and as products of other decompositional reactions. Precambrian Res., 32: 155-179.

Retallack, G.J. 1988. Field recognition of paleosols. In: J. Reinhardt and W.R. Sigleo (Editors), Paleosols and Weathering Through Geologic Time: Principles and Applications. Geol. Soc. Am., Spec. Pap. 216: pp. 1-20.

----- 1991. Untangling the effects of burial alteration and ancient soil formation. Annu. Rev. Earth Planet. Sci., 19: 183-206. 1992. Soils of the past. Unwin Hyman, Boston, $520 \mathrm{pp}$. 
Singer, A. 1988. Illite in aridic soils, desert dusts and desert loess. Sed. Geol., 59: 251-259.

Wiggering, H. and Beukes, N.J. 1990. Petrography and geochemistry of a 2000-2200Ma-old hematitic paleo-alteration profile on Ongeluk basalt of the Transvaal Supergroup, Griqualand West, South Africa. Precambrian Res., 46: 241-258.

Williams, G.E. 1968. Torridonian weathering, and its bearing on Torridonian paleoclimate and source. Scott. J. Geol., 4: 164-184.

Wipple, E.R. 1974. A study of Wilson's determination of ferrous iron in silicates. Chem. Geol., 14: 223-238.

Wolfenden, E.B. 1965. Geochemical behaviour of trace elements during bauxite formation in Sarawak, Malaysia. Geochim. Cosmochim. Acta, 29: 1051-1062. 


\section{FIGURE CAPTIONS}

Figure 2.1.1. (A) Distribution of four correlative Proterozoic basins in the northwestern part of the Canadian Shield. (B) Generalized geology (after Miller and LeCheminant, 1985) of the Thelon Basin and surrounding area, showing the location of four (numbered) sub-Thelon Formation paleosol profiles. These profiles are shown as locality 12 in Fig. 1.1.

Figure 2.1.2. Concentration ratio distributions for major and trace elements for Profile 1 protolith (14 to 18) and paleosol (4 to 12) samples. (A) $\mathrm{SiO}_{2}, \mathrm{TiO}_{2}, \mathrm{MnO}$, (B) $\mathrm{Fe}_{2} \mathrm{O}_{3}, \mathrm{FeO}$, Fe Total, (C) $\mathrm{Na}_{2} \mathrm{O}, \mathrm{K}_{2} \mathrm{O}$, (D) $\mathrm{P}_{2} \mathrm{O}_{5}, \mathrm{MgO}, \mathrm{CaO}$, (E) Ba, Sr, Rb, (F) Cr, U, Zr.

Figure 2.1.3. Chemical Index of Alteration (CIA) plots of the four Thelon paleosol profiles. D.F.C. $=$ distance from collar.

Figure 2.1.4. Illite (I) growth on feldspar and hematitized biotite (B) in incipiently paleoweathered granite, Profile 2. Bar scale $=1.0 \mathrm{~mm}$.

Figure 2.1.5. Illite (I) pseudomorphous after vermiform kaolinite (K). Hematite cement $(\mathrm{H})$ post-dates the kaolinite. Bar scale $=0.125 \mathrm{~mm}$.

Figure 2.1.6. Stylocumulates (arrows) within a Profile 2 paleosol sample, are in part 
defined by hematite. Bar scale $=0.5 \mathrm{~mm}$.

Figure 2.1.7. Interstitial chert and microquartz cement (Q) post-dated by vermiform kaolinite (K), within Profile 2 Thelon Formation sandstone. Bar scale $=1.0 \mathrm{~mm}$.

Figure 2.1.8. Concentration ratio distribution for major and trace elements in Profile 2 protolith (6 and $7 \mathrm{~m}$ ) and paleosol (4 and $5 \mathrm{~m}$ ) samples. (A) $\mathrm{SiO}_{2}, \mathrm{TiO}_{2}, \mathrm{MnO}$, (B) $\mathrm{Fe}_{2} \mathrm{O}_{3}, \mathrm{FeO}, \mathrm{Fe}$ Total, (C) $\mathrm{Na}_{2} \mathrm{O}, \mathrm{K}_{2} \mathrm{O}$, (D) $\mathrm{P}_{2} \mathrm{O}_{5}, \mathrm{MgO}, \mathrm{CaO}$, (E) Ba, Sr, Rb, (F) Cr, U, Zr.

Figure 2.1.9. Garnet porphyroblast (arrows) altered to hematite (H). Some garnet inclusions are replaced by kaolinite $(\mathrm{K})$ and a fibrous vermiculite- or chlorite-type phyllosilicate (VC). Bar scale $=0.5 \mathrm{~mm}$.

Figure 2.1.10. Interstitial vermiform kaolinite $(\mathrm{K})$ pseudomorphed and overgrown by fibrous illite $(\mathrm{I})$ within Profile 3 Thelon Formation sandstone. Bar scale $=0.25$ $\mathrm{mm}$.

Figure 2.1.11. Concentration ratio distribution for major and trace elements in Profile 3. Paleosol extends from approximately 104.0 to 107.0 metres. D.F.C. $=$ distance from collar, in metres. (A) $\mathrm{SiO}_{2}, \mathrm{TiO}_{2}, \mathrm{MnO}$, (B) $\mathrm{Fe}_{2} \mathrm{O}_{3}, \mathrm{FeO}$, Fe Total, (C) $\mathrm{Na}_{2} \mathrm{O}, \mathrm{K}_{2} \mathrm{O}$, (D) $\mathrm{P}_{2} \mathrm{O}_{5}, \mathrm{MgO}, \mathrm{CaO}$, (E) Ba, Sr, Rb, (F) Cr, U, Zr. 
Figure 2.1.12. Kaolinite (K), which extends from the corroded alkali feldspar grain (F) into the interstices, appears to have formed by alteration of the alkali feldspar. Bar scale $=0.25 \mathrm{~mm}$.

Figure 2.1.13. Concentration ratio distribution for major and trace elements in Profile 4. D.F.C. = distance from collar, in feet; paleosol extends from approximately 177.0 to 367.0 feet. (A) $\mathrm{SiO}_{2}, \mathrm{TiO}_{2}, \mathrm{MnO}$, (B) $\mathrm{Fe}_{2} \mathrm{O}_{3}$, FeO, Fe Total, (C) $\mathrm{Na}_{2} \mathrm{O}$, $\mathrm{K}_{2} \mathrm{O}$, (D) $\mathrm{P}_{2} \mathrm{O}_{5}, \mathrm{MgO}, \mathrm{CaO}$, (E) Ba, Sr, Rb, (F) Cr, U, Zr.

Figure 2.1.14. Ternary plots of the four profiles, depicting the depletion of $\mathrm{CaO}$, $\mathrm{Na}_{2} \mathrm{O}$ and $\mathrm{K}_{2} \mathrm{O}$, relative to $\mathrm{Al}_{2} \mathrm{O}_{3}$, in the paleosol compared to 'fresh' protolith.

Figure 2.1.15. Composite paragenetic sequence of mineral development during formation of the Thelon paleosol (PALEOWEATHERING), and during subsequent Thelon Formation diagenesis. The dashed part of the dividing line indicates paleosol phyllosilicates for which the effects of diagenetic overprinting are uncertain. 'Time' indicates relative order of mineral development. 


$$
2-1-39
$$

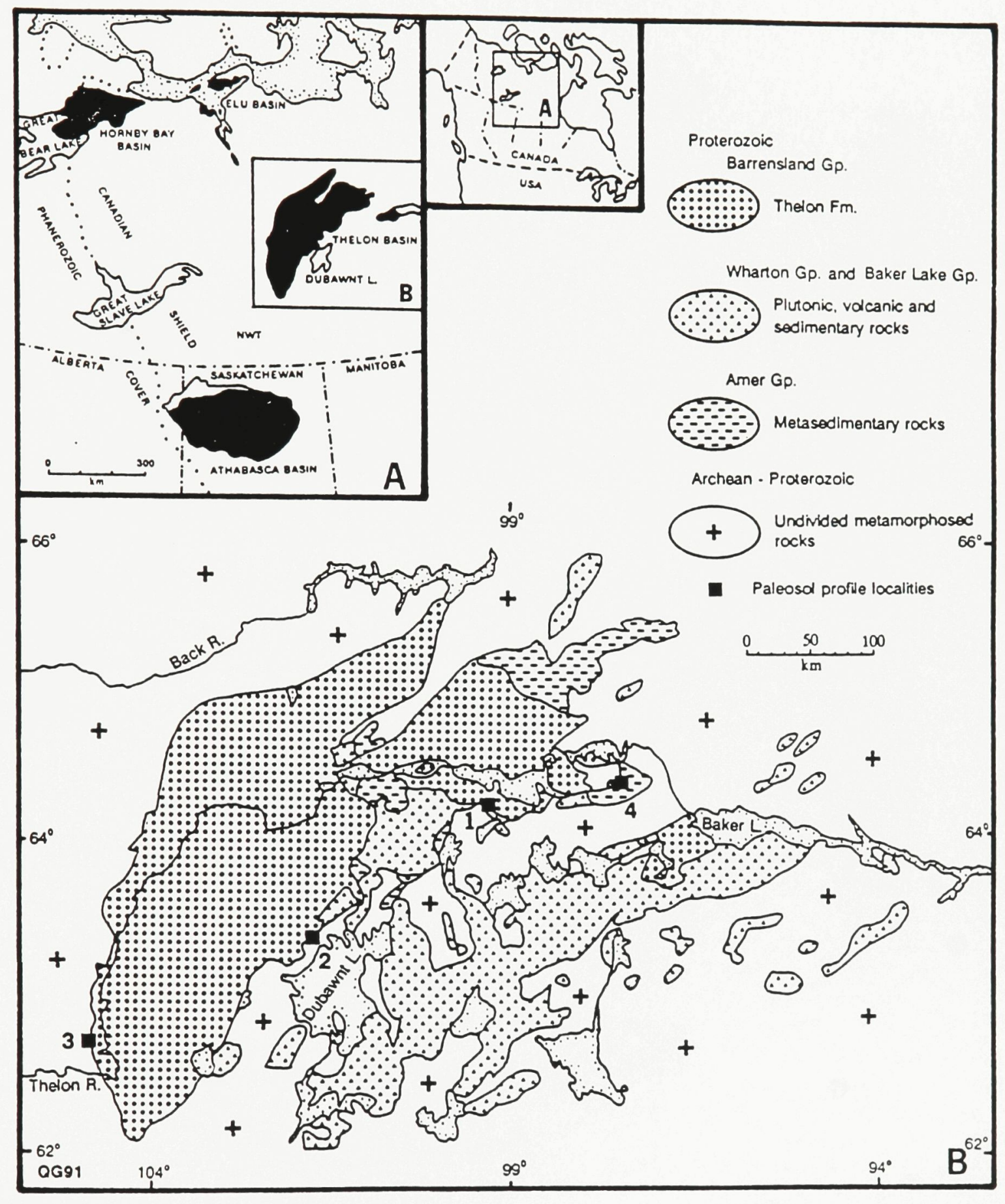

Fig. 2.1.1 


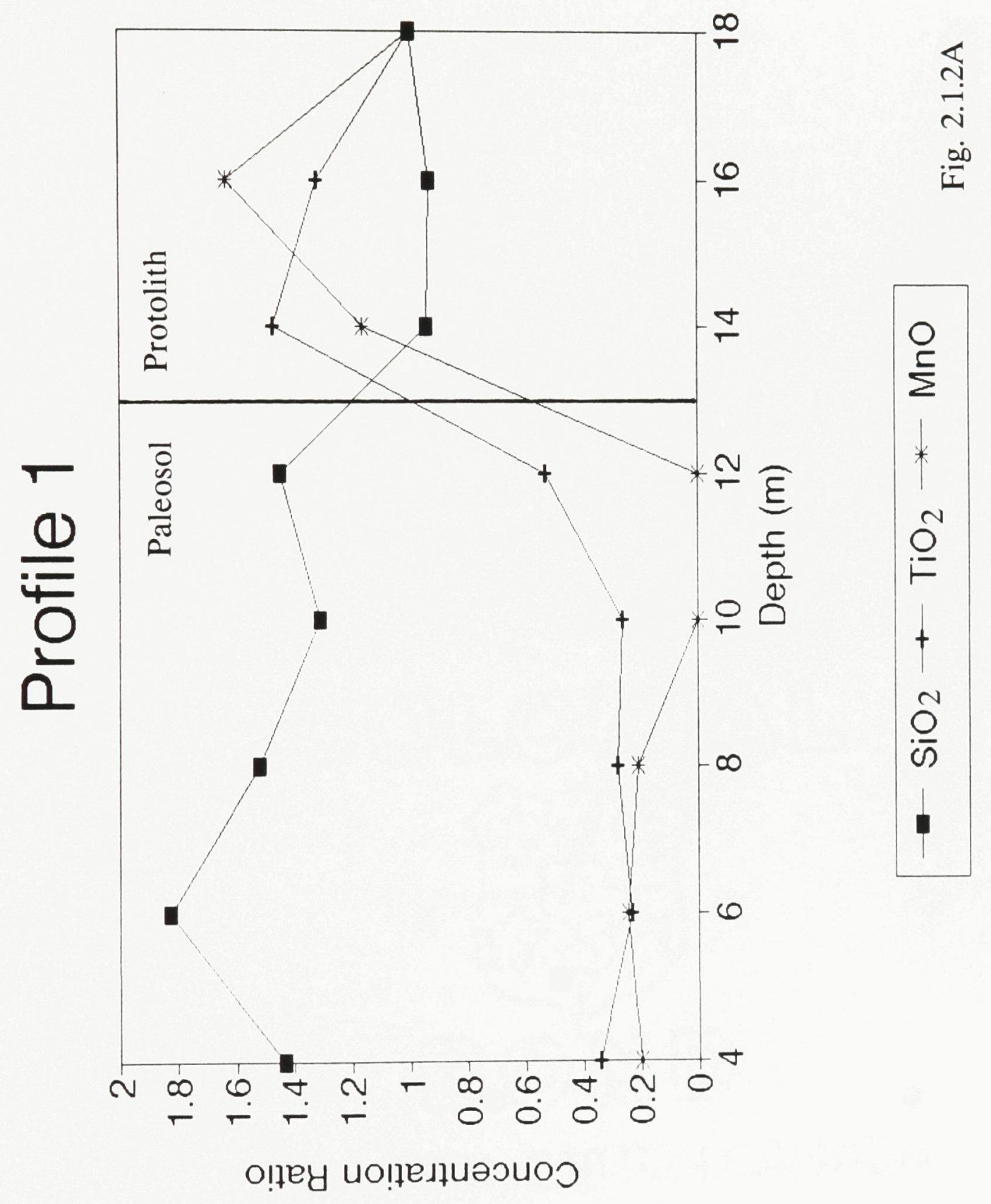




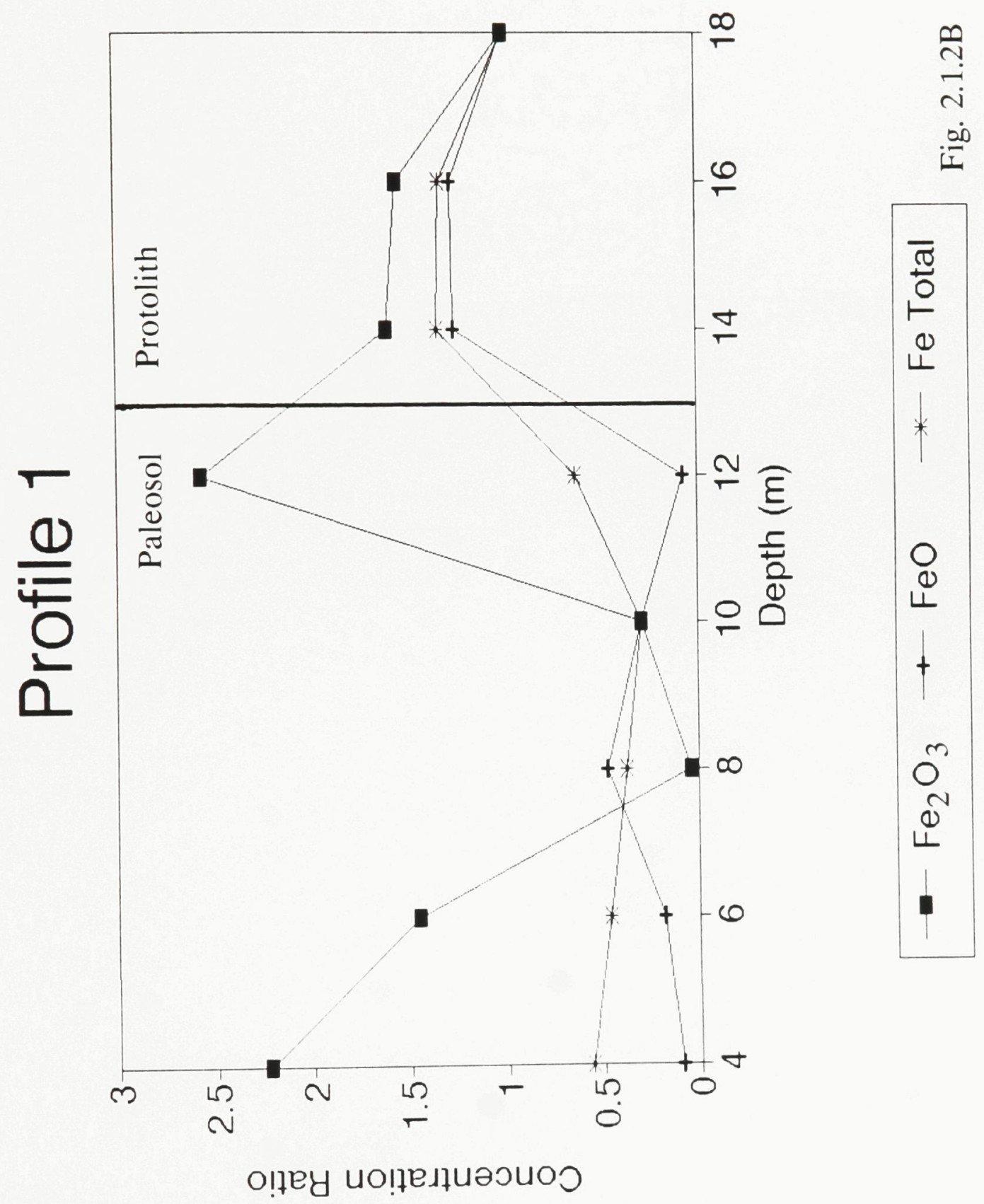




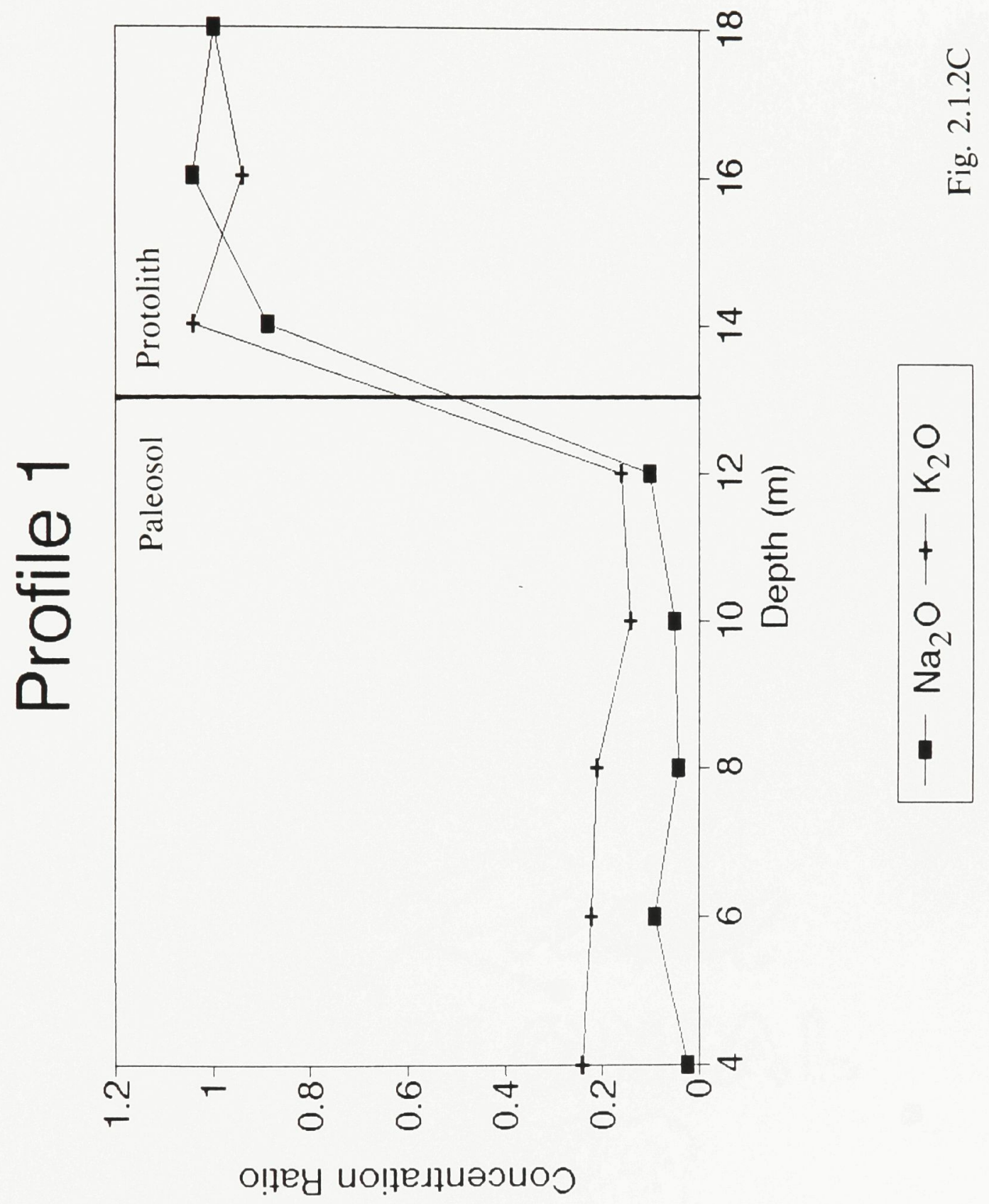




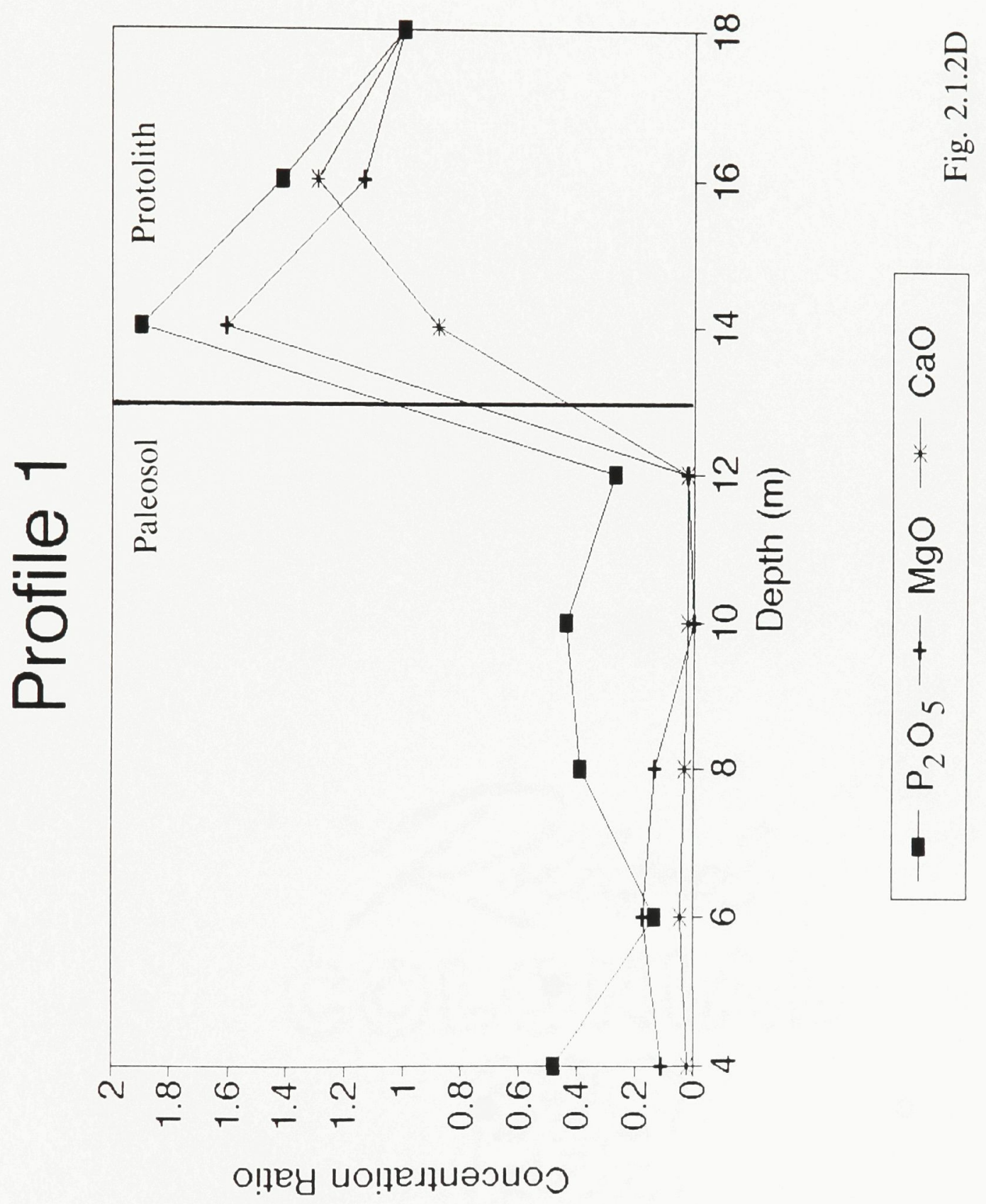




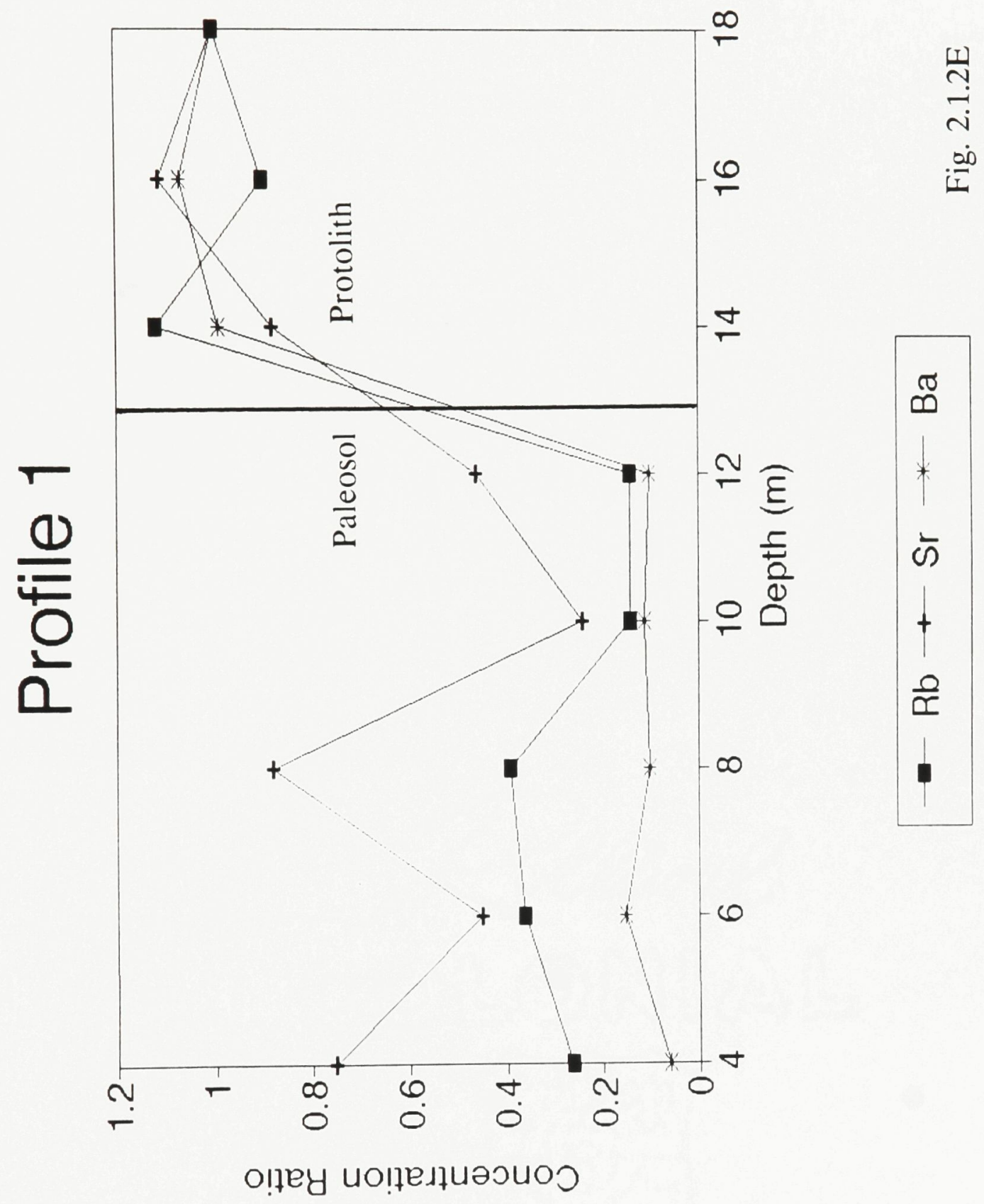




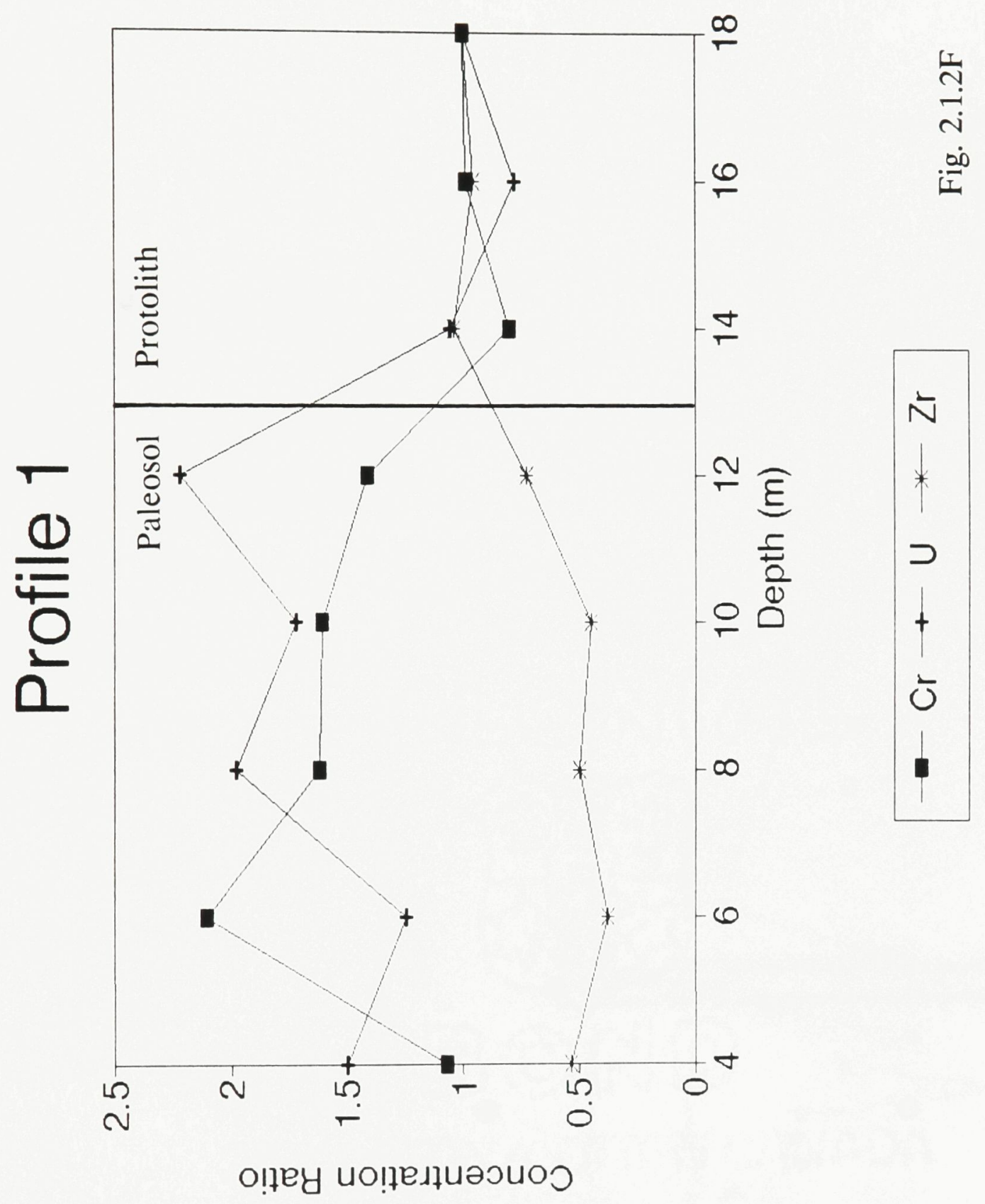



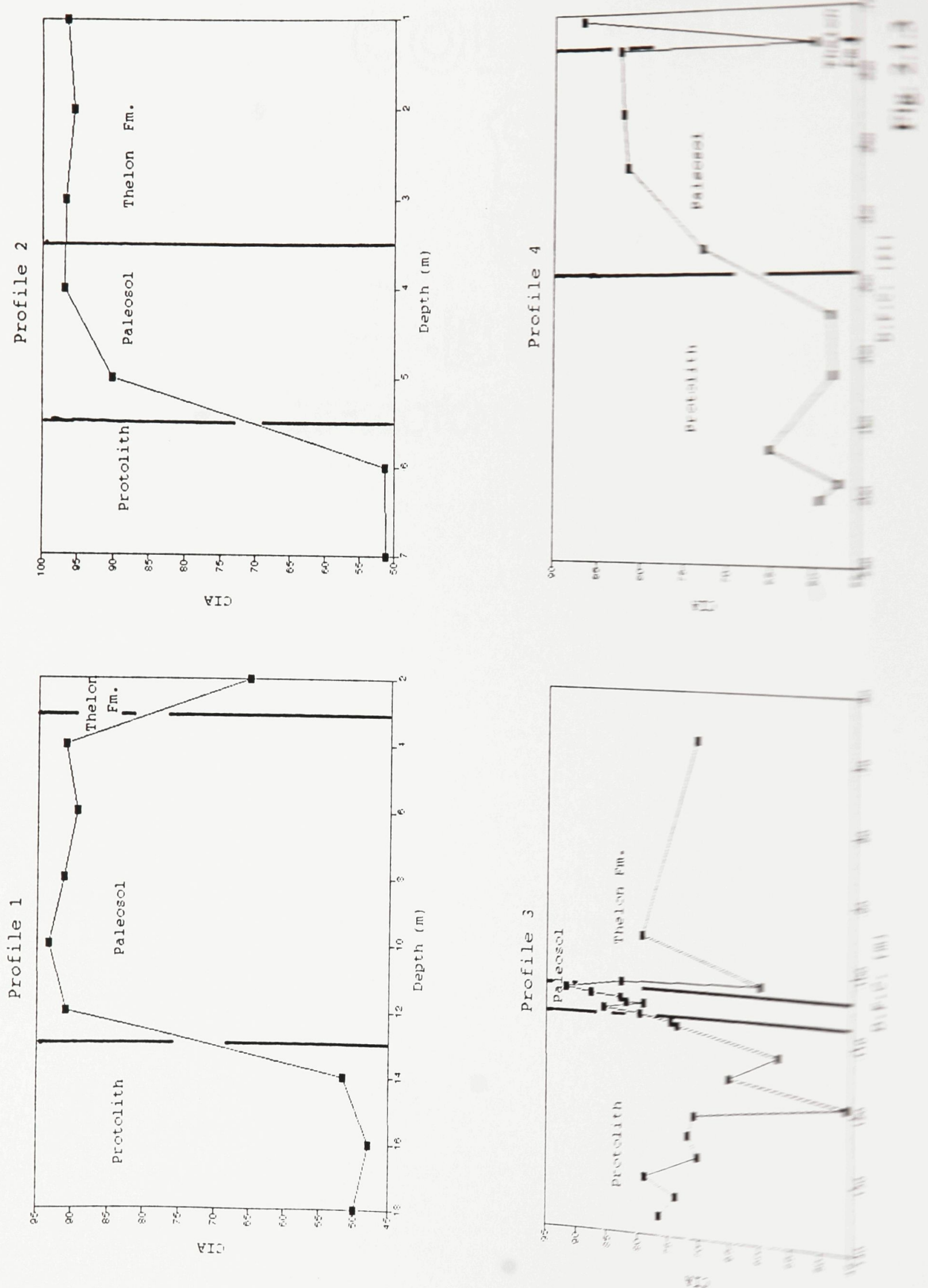

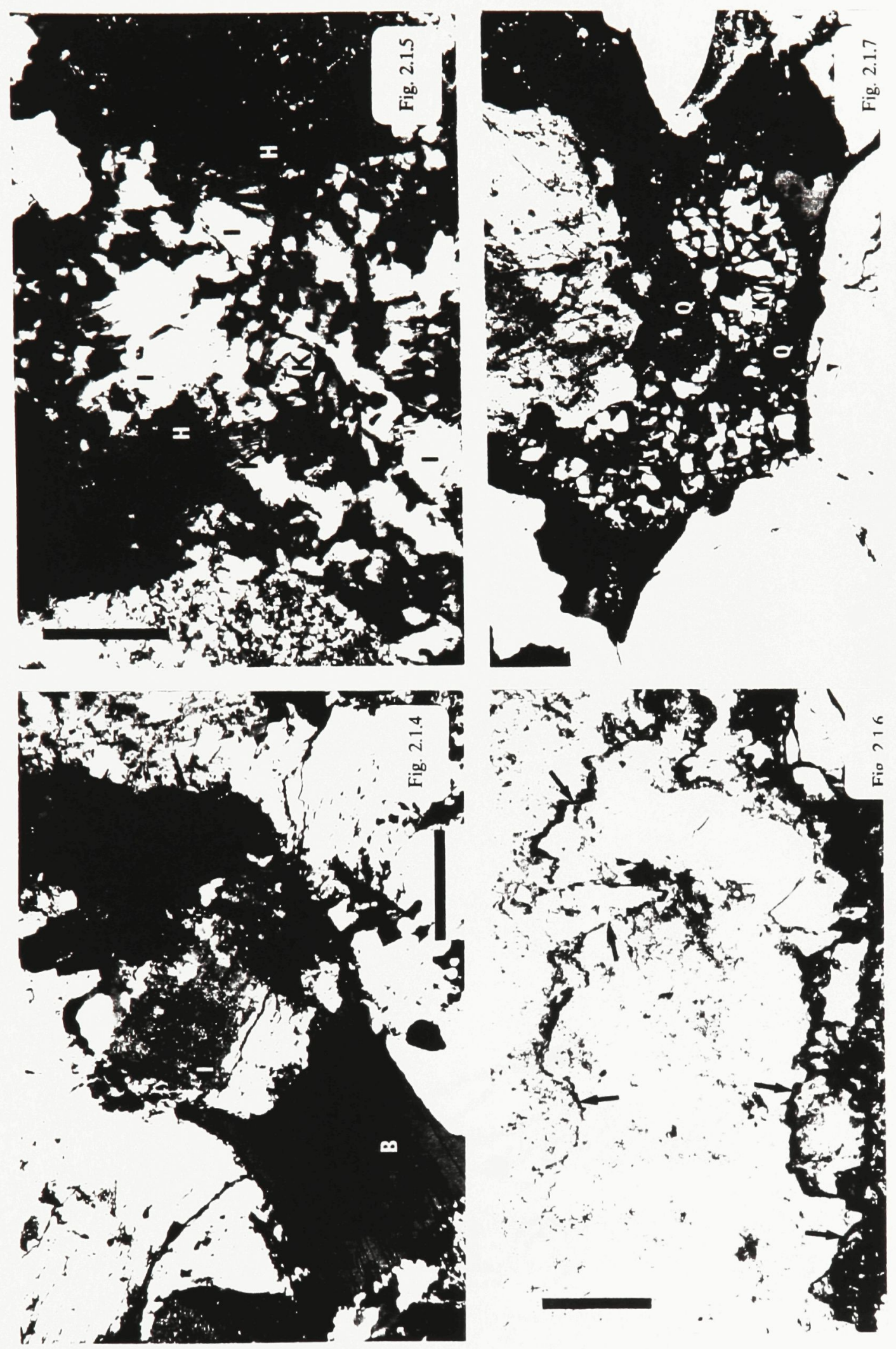


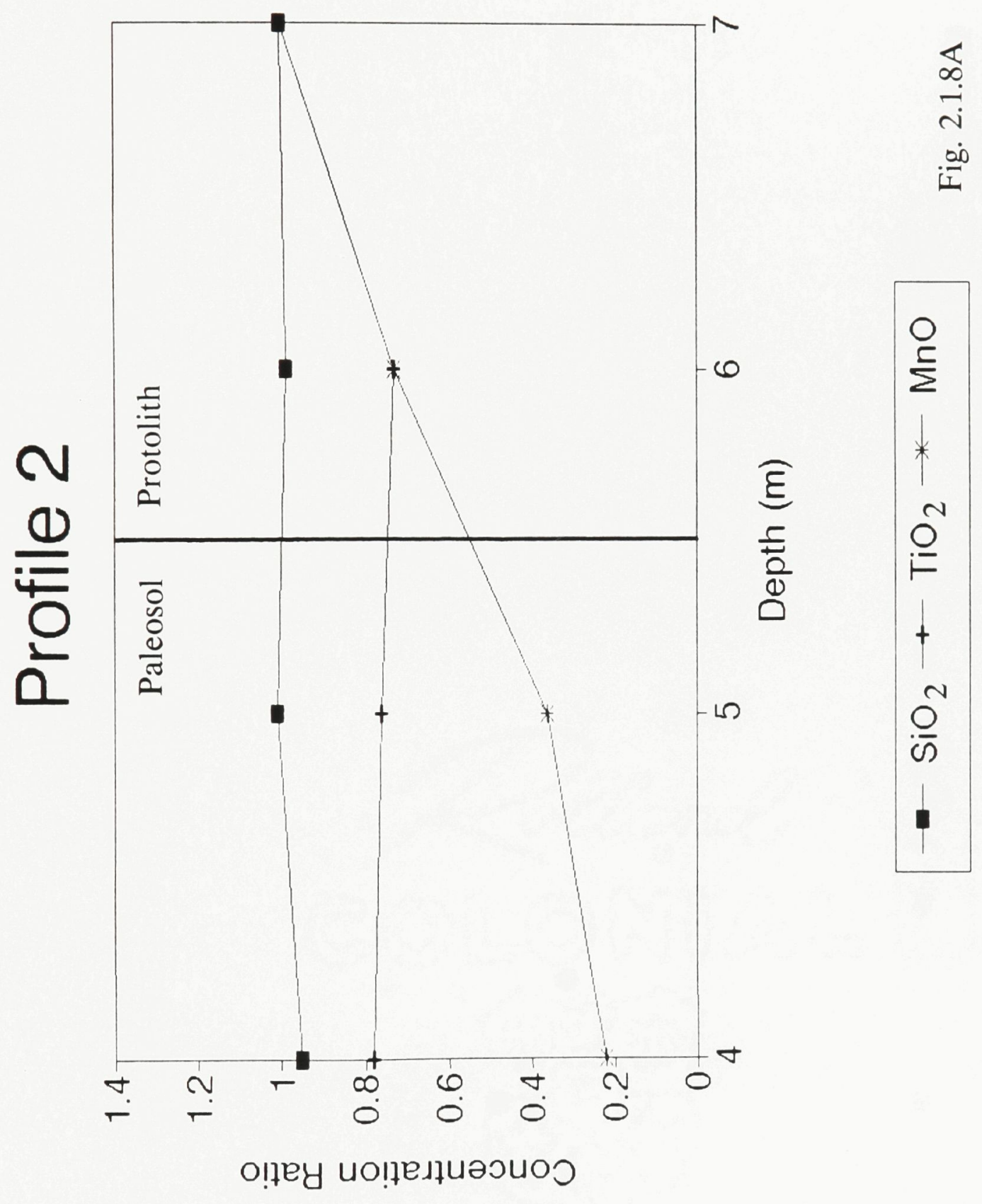




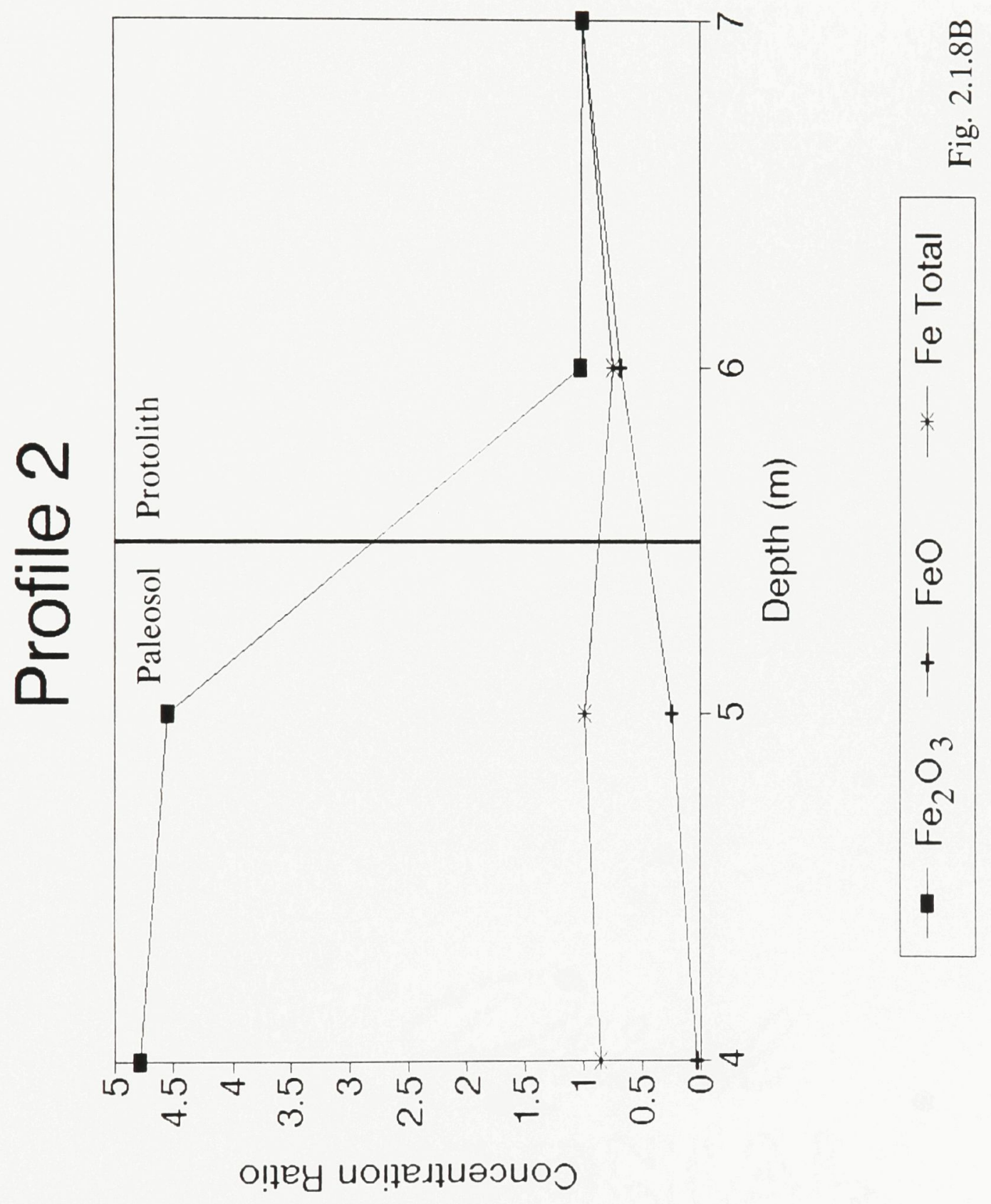




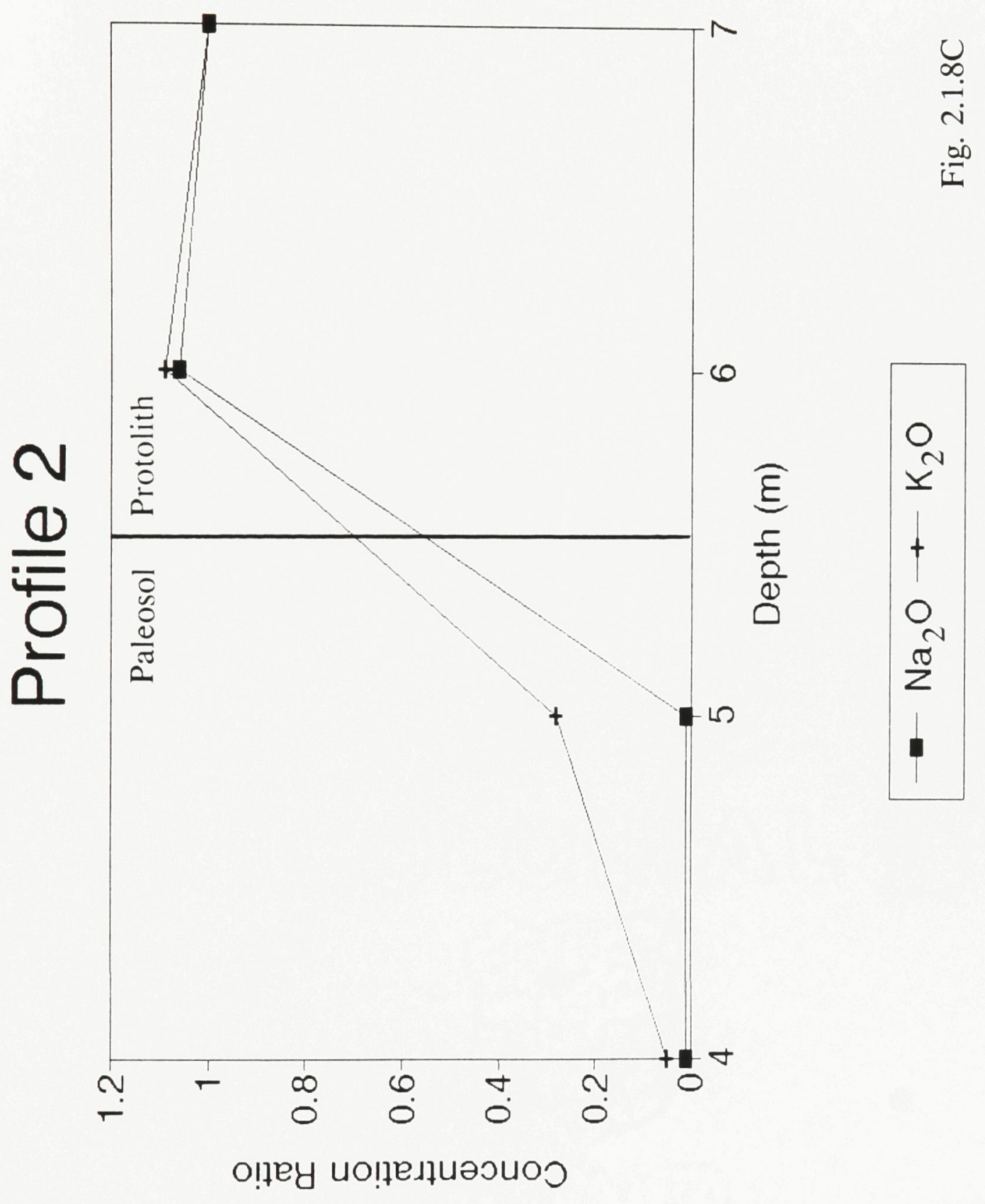




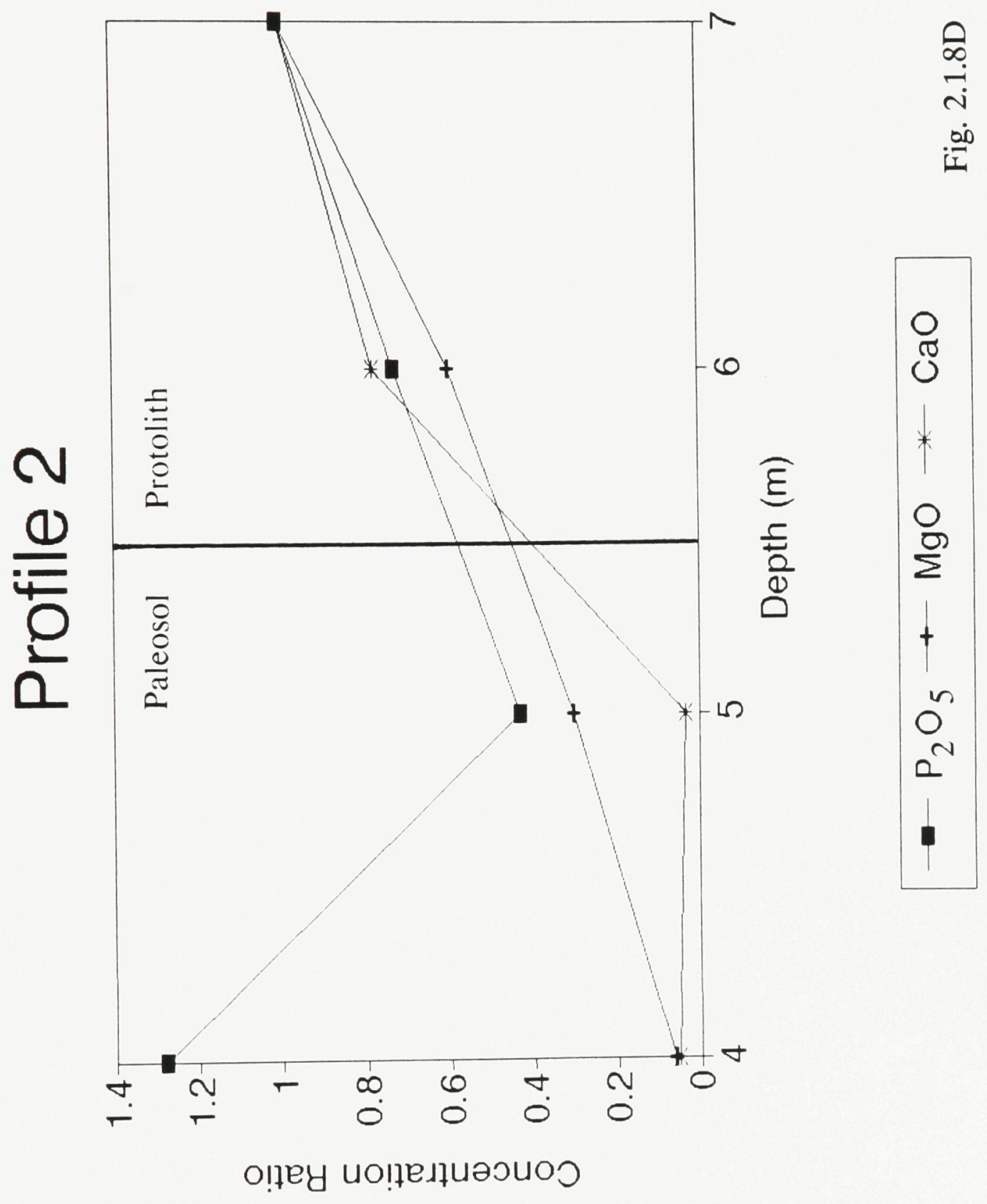




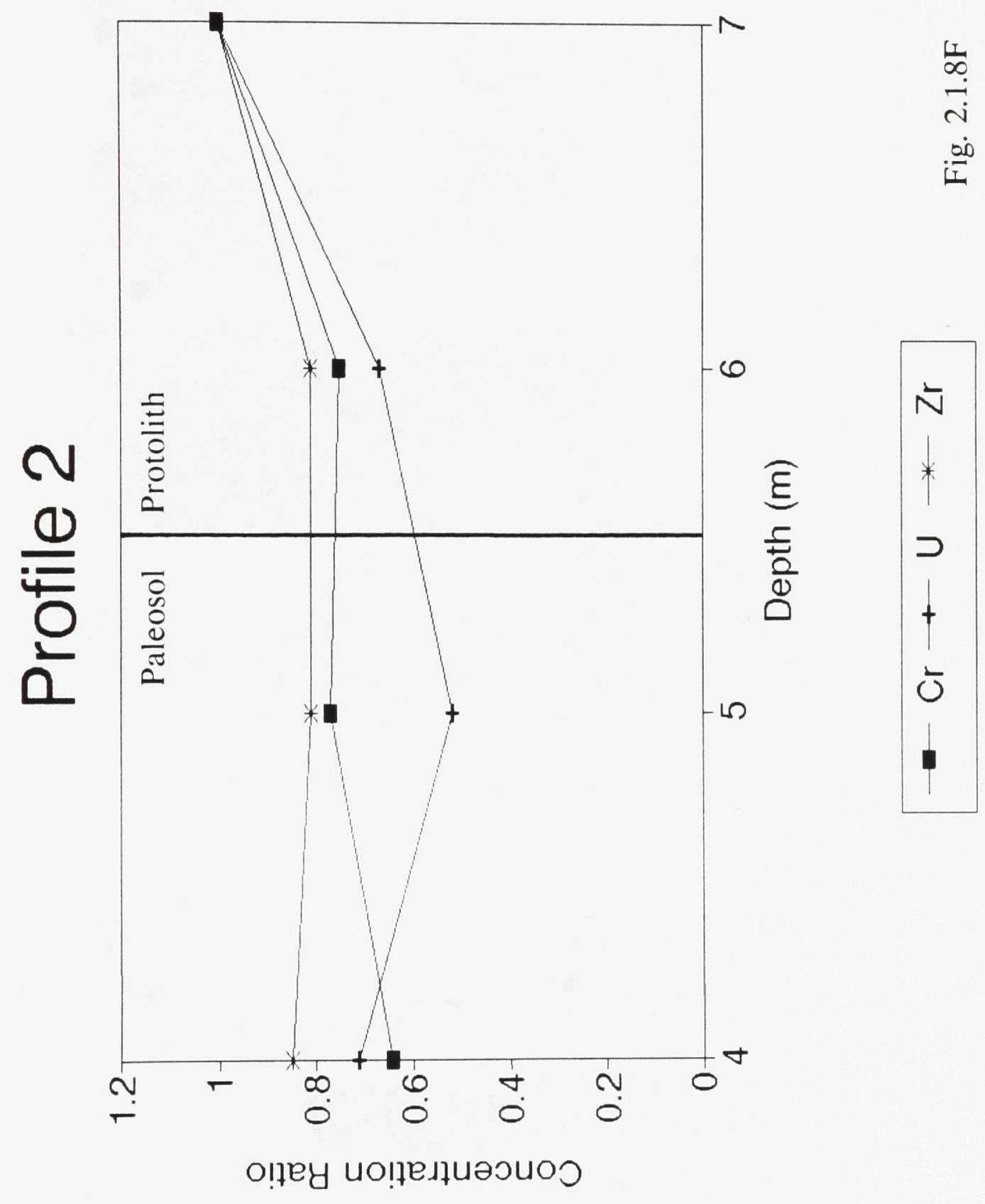



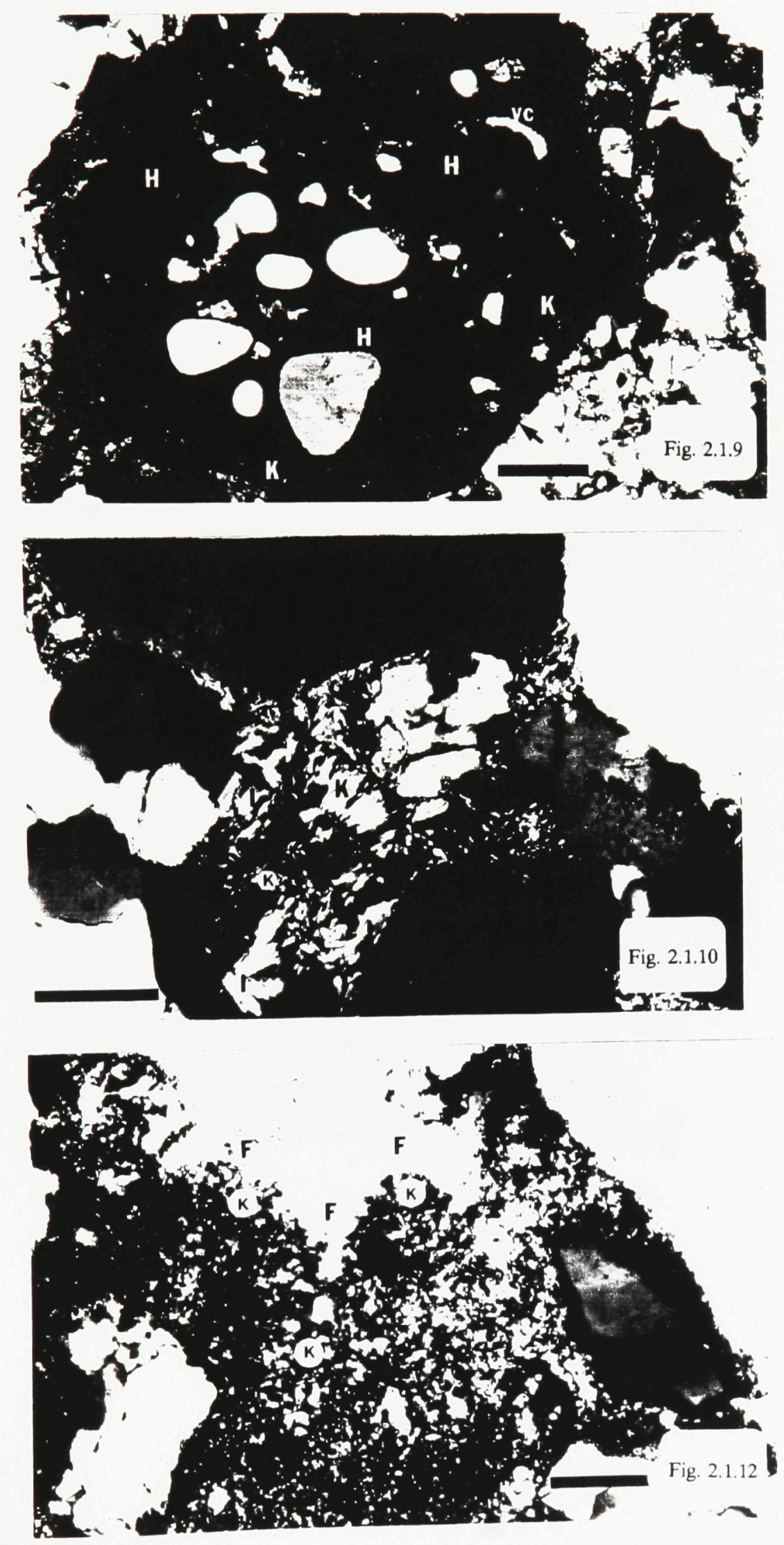


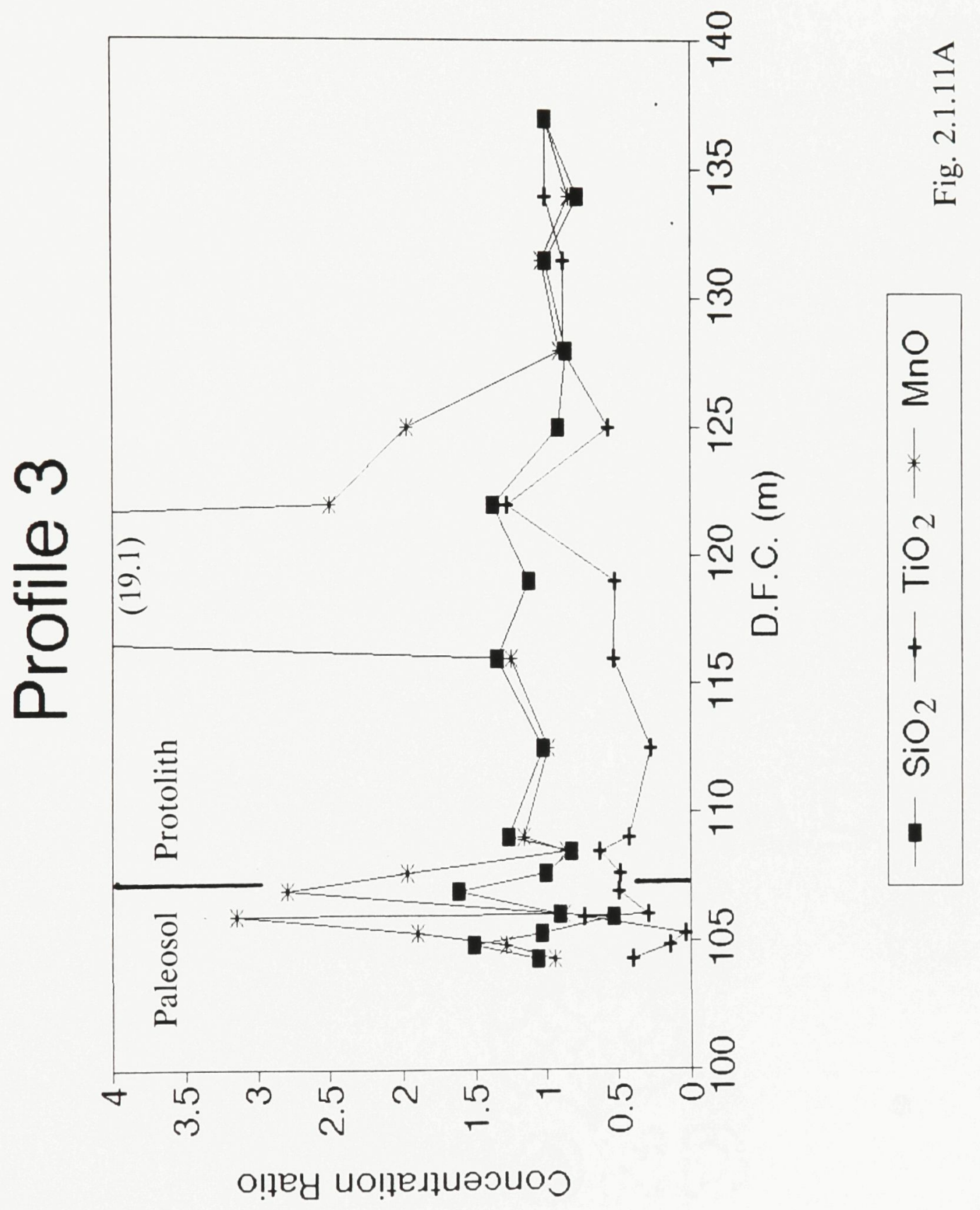




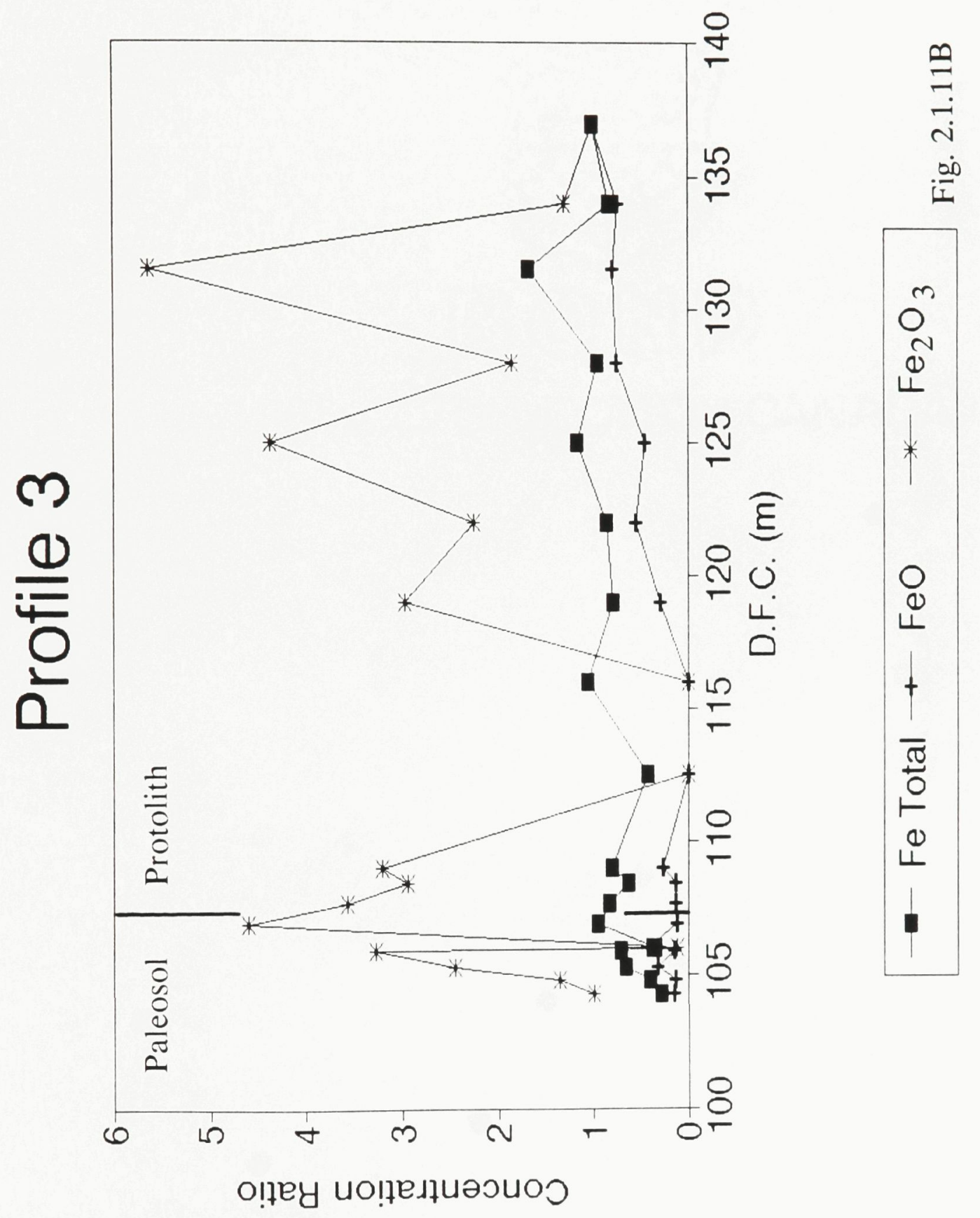




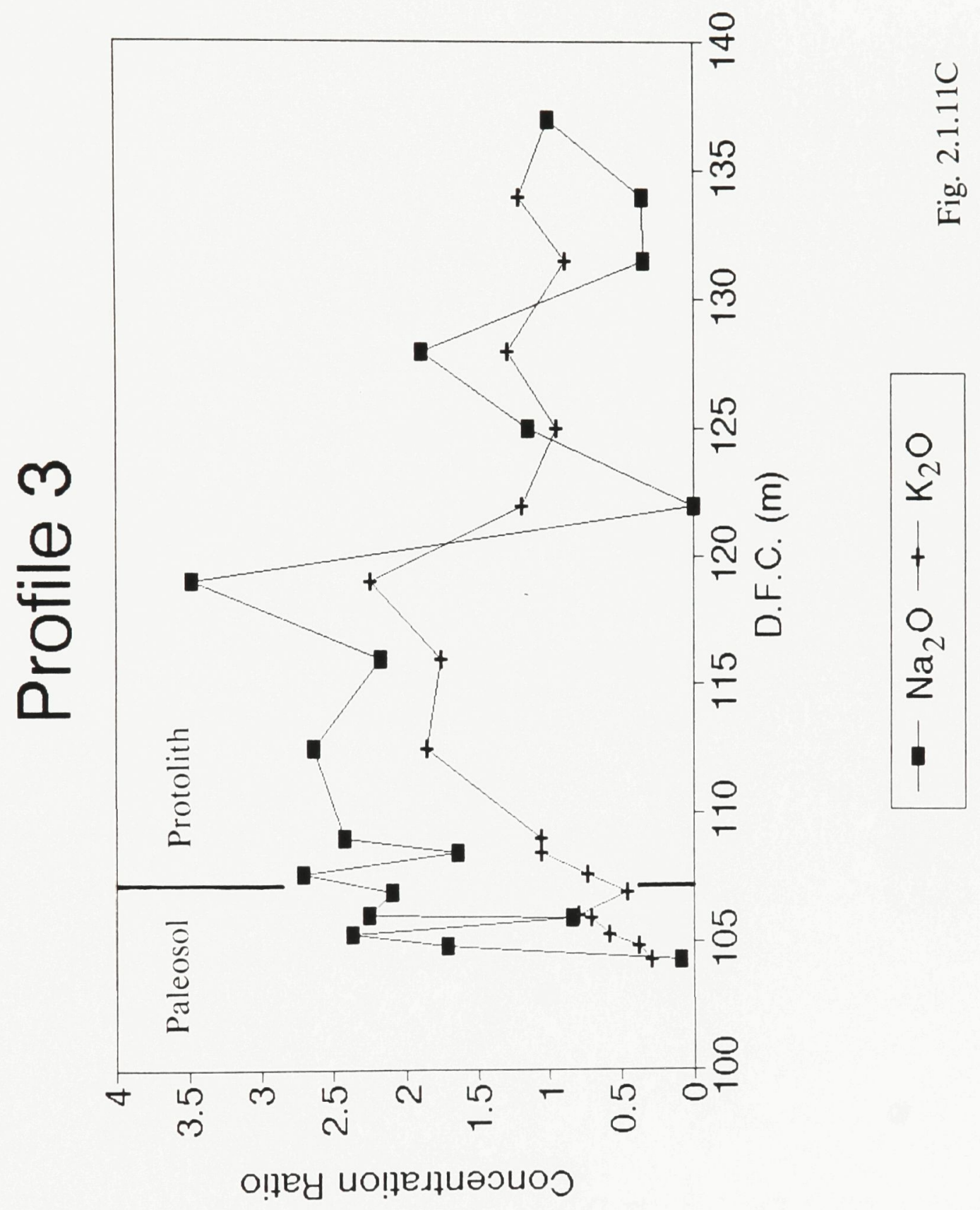




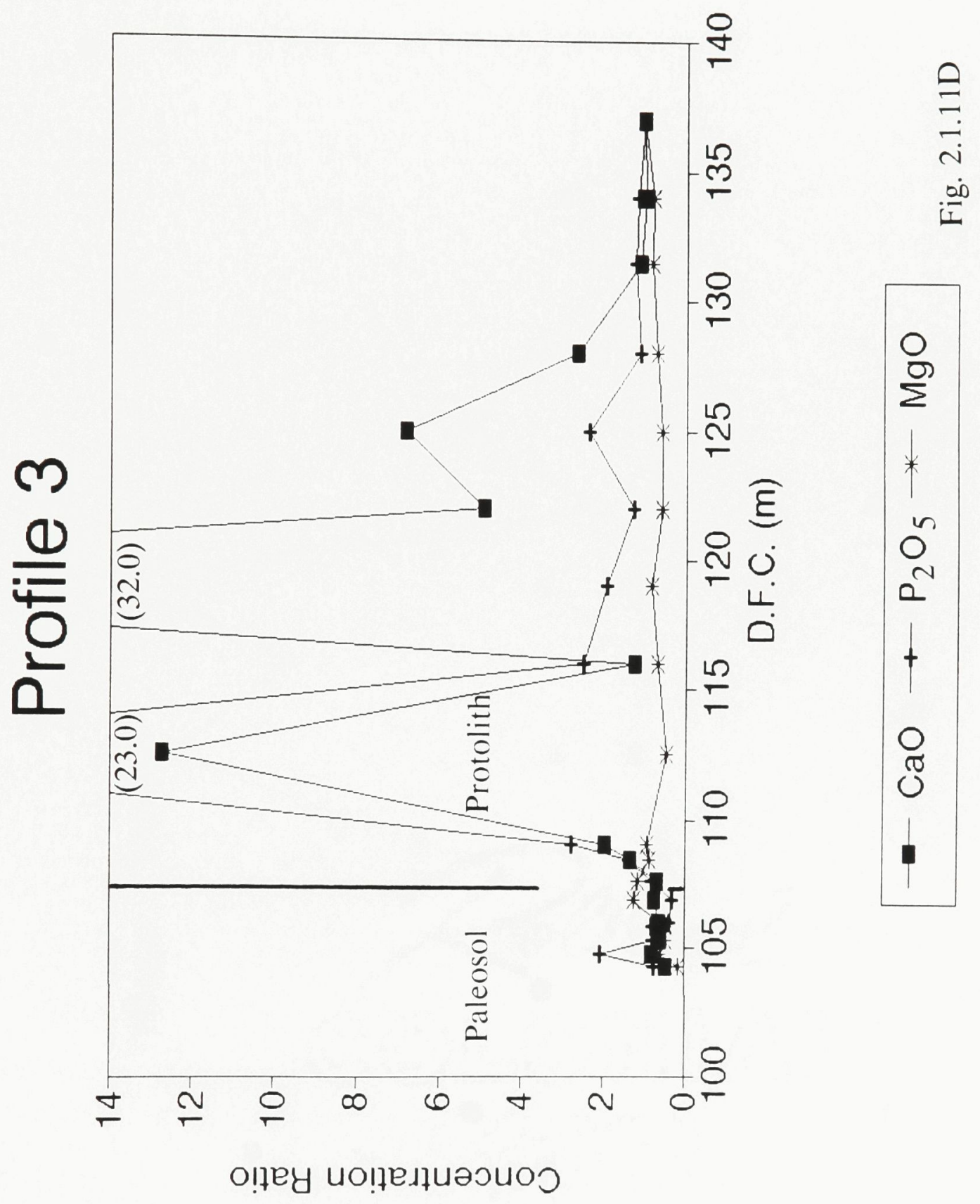




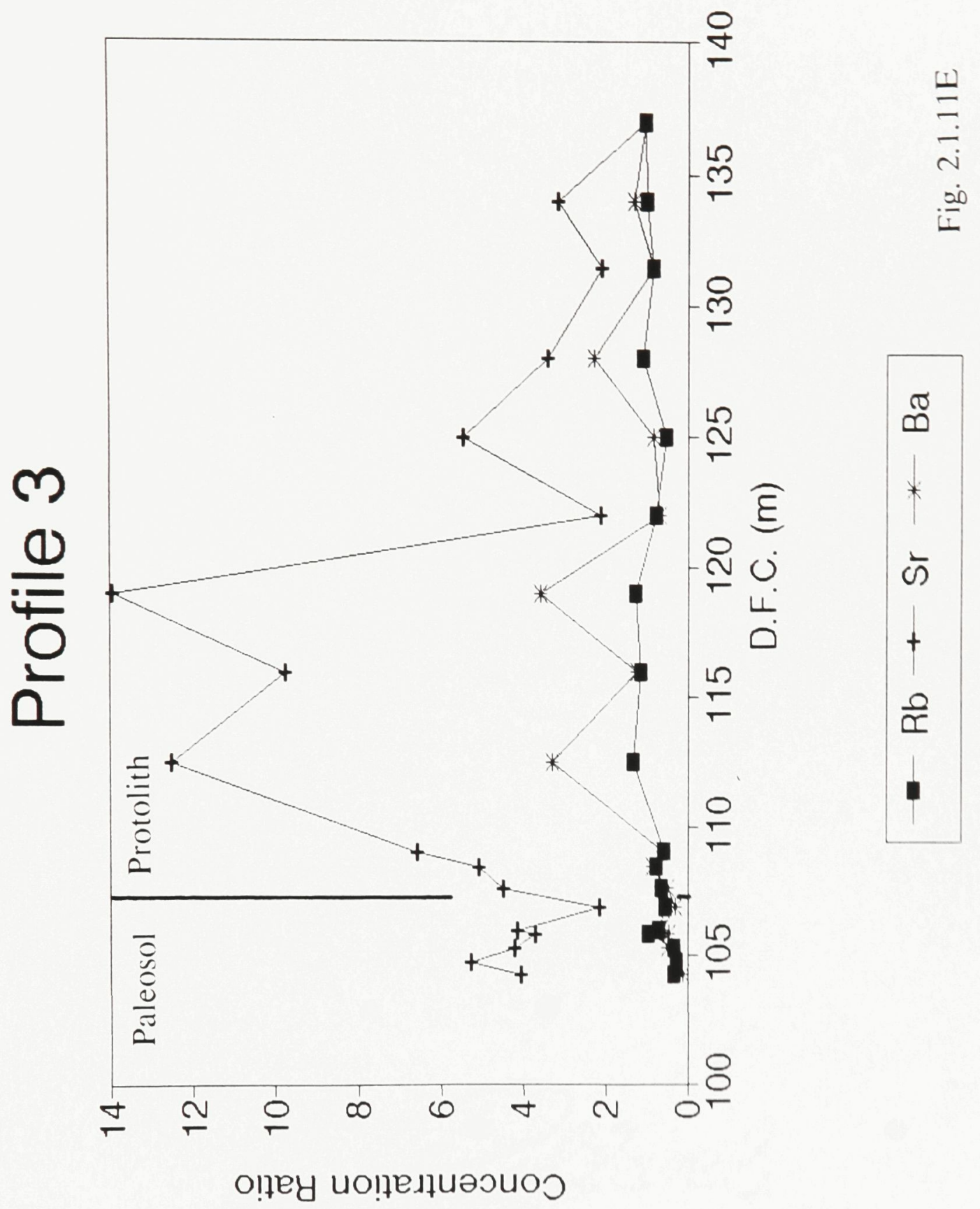




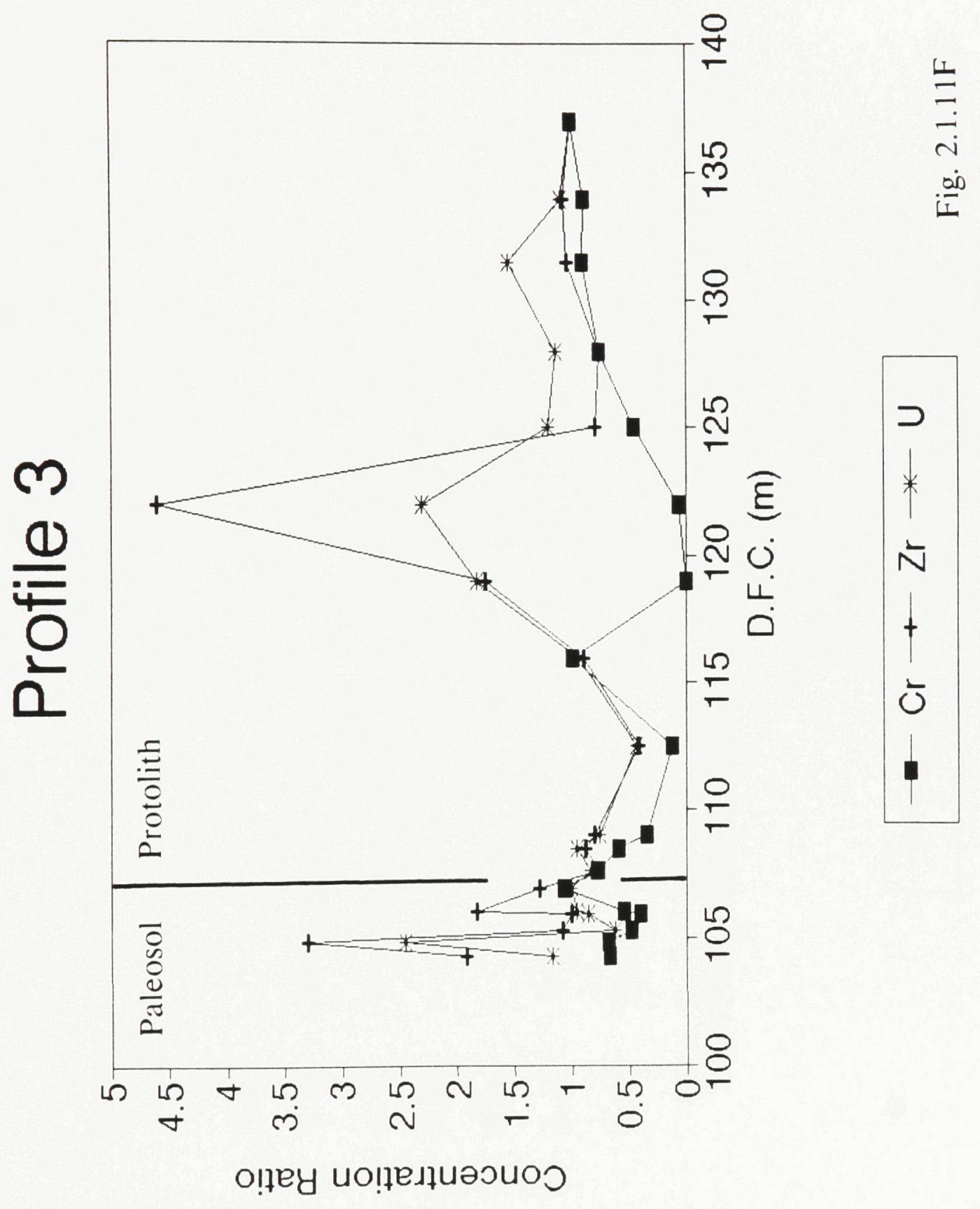




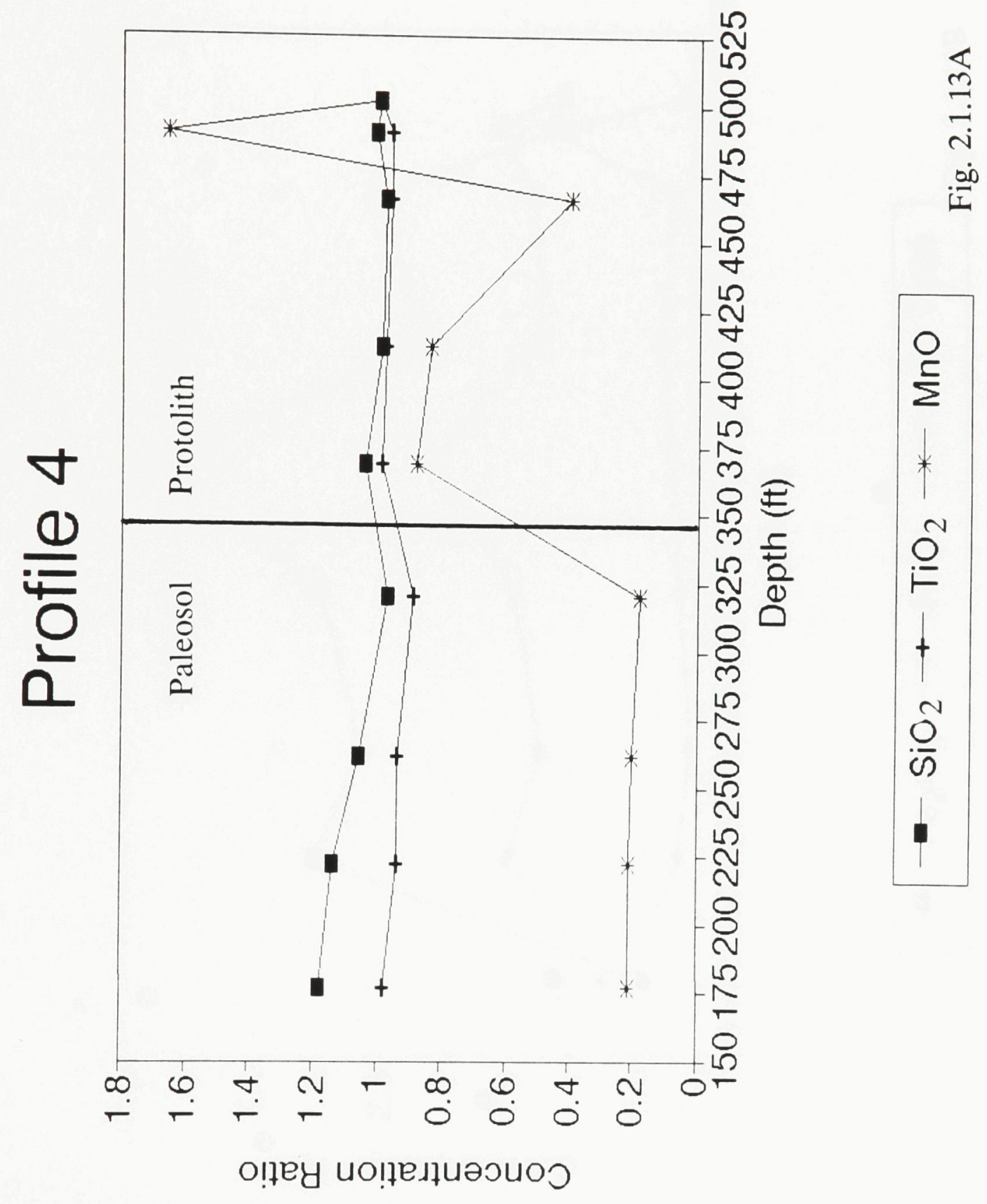




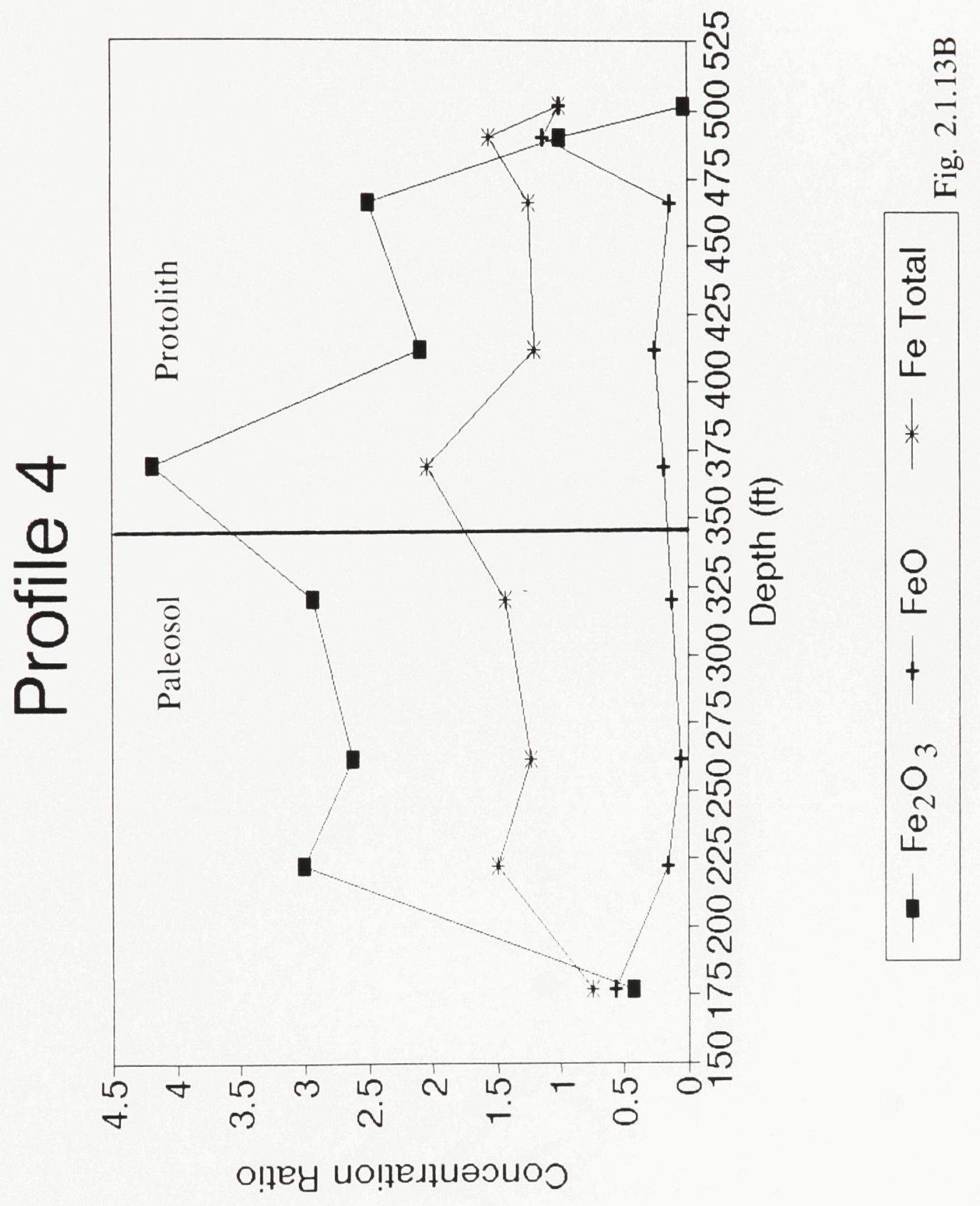




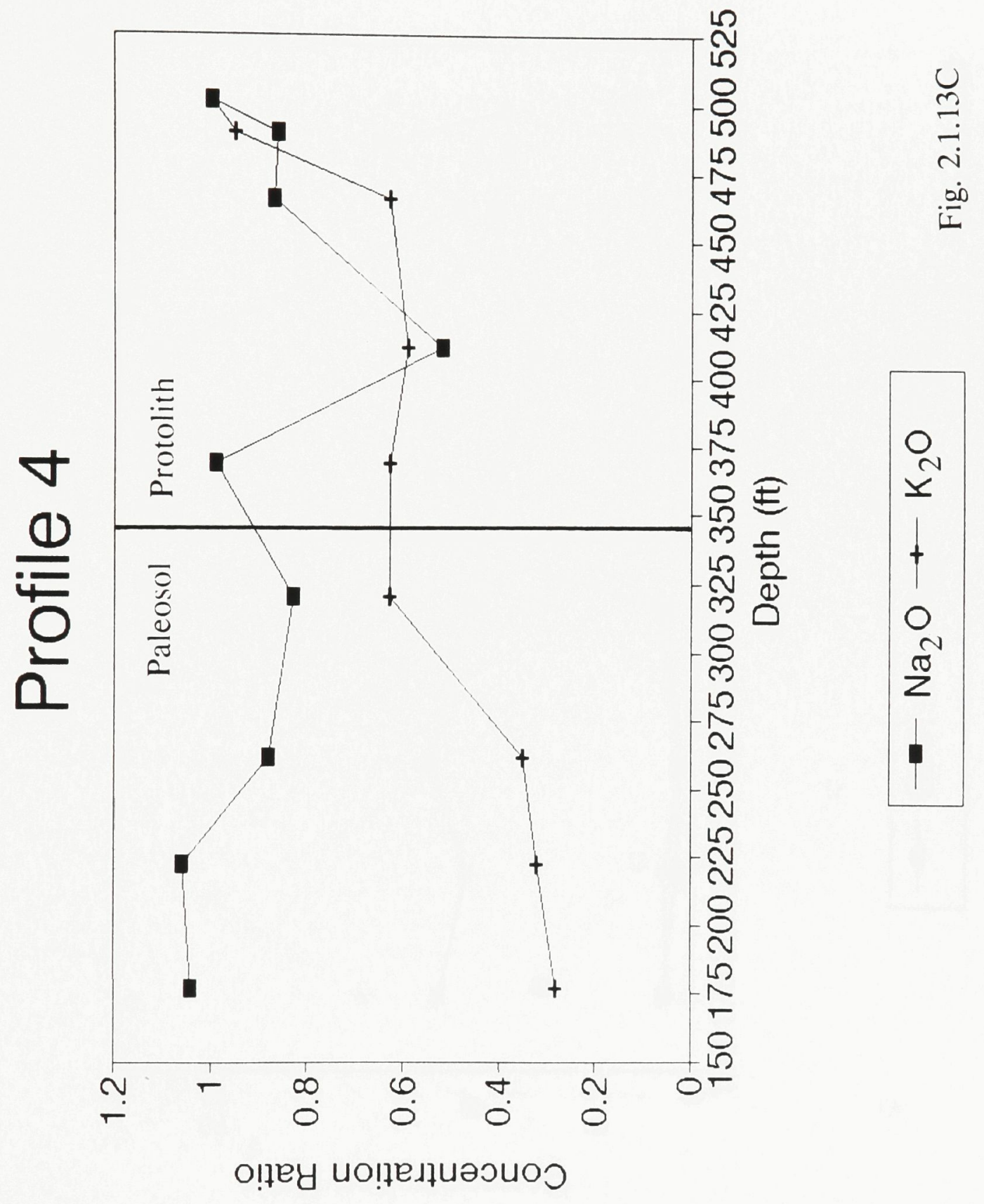




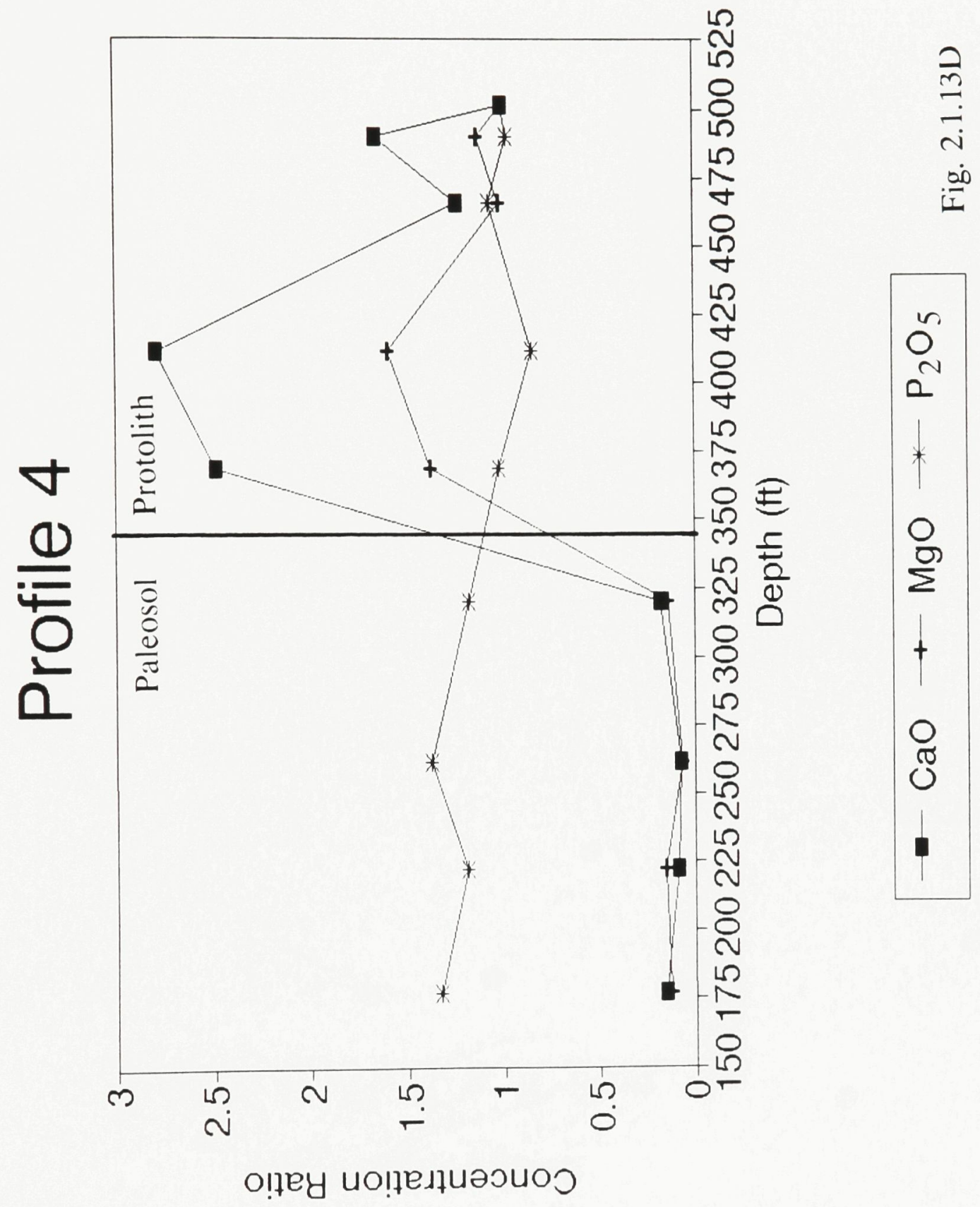




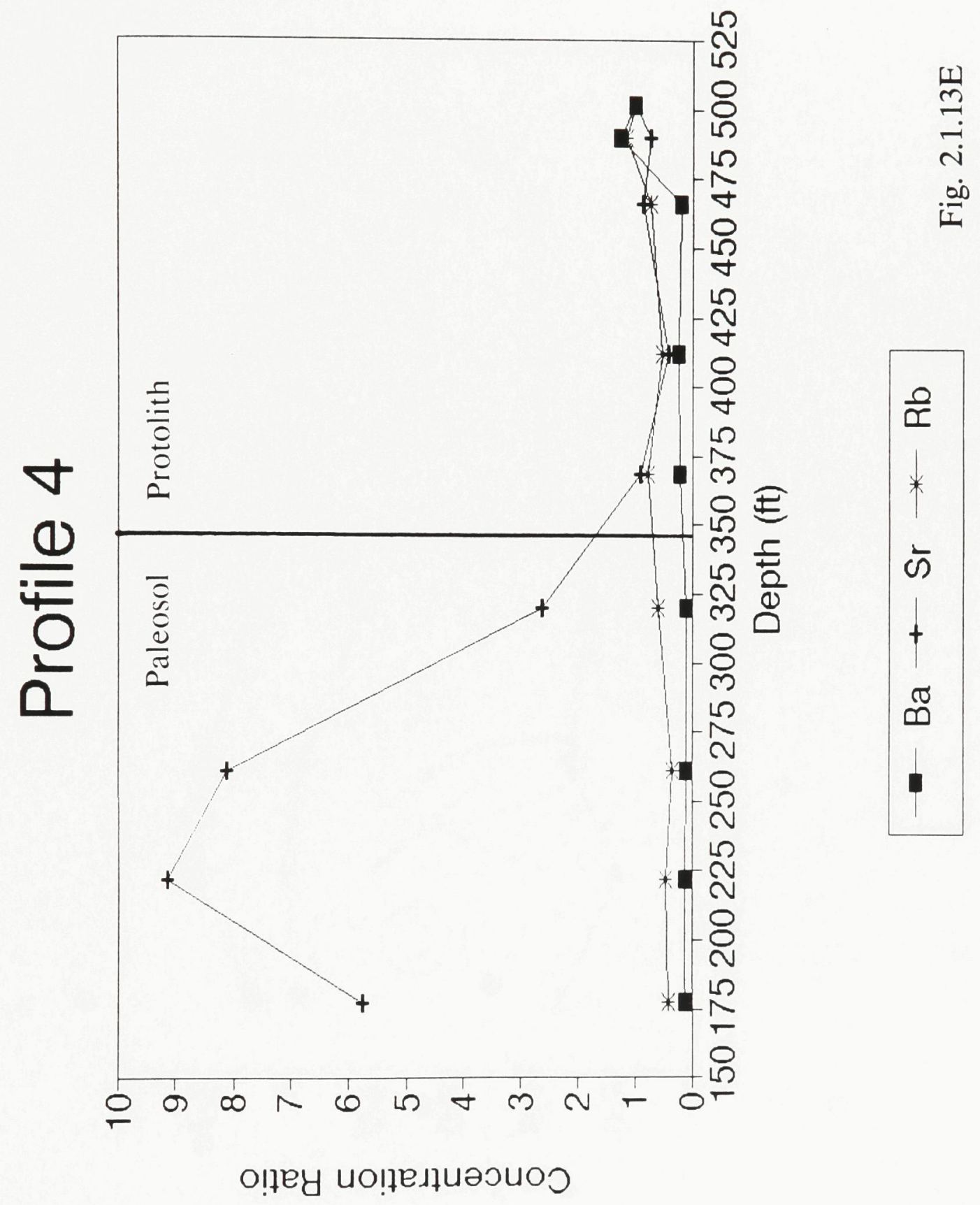




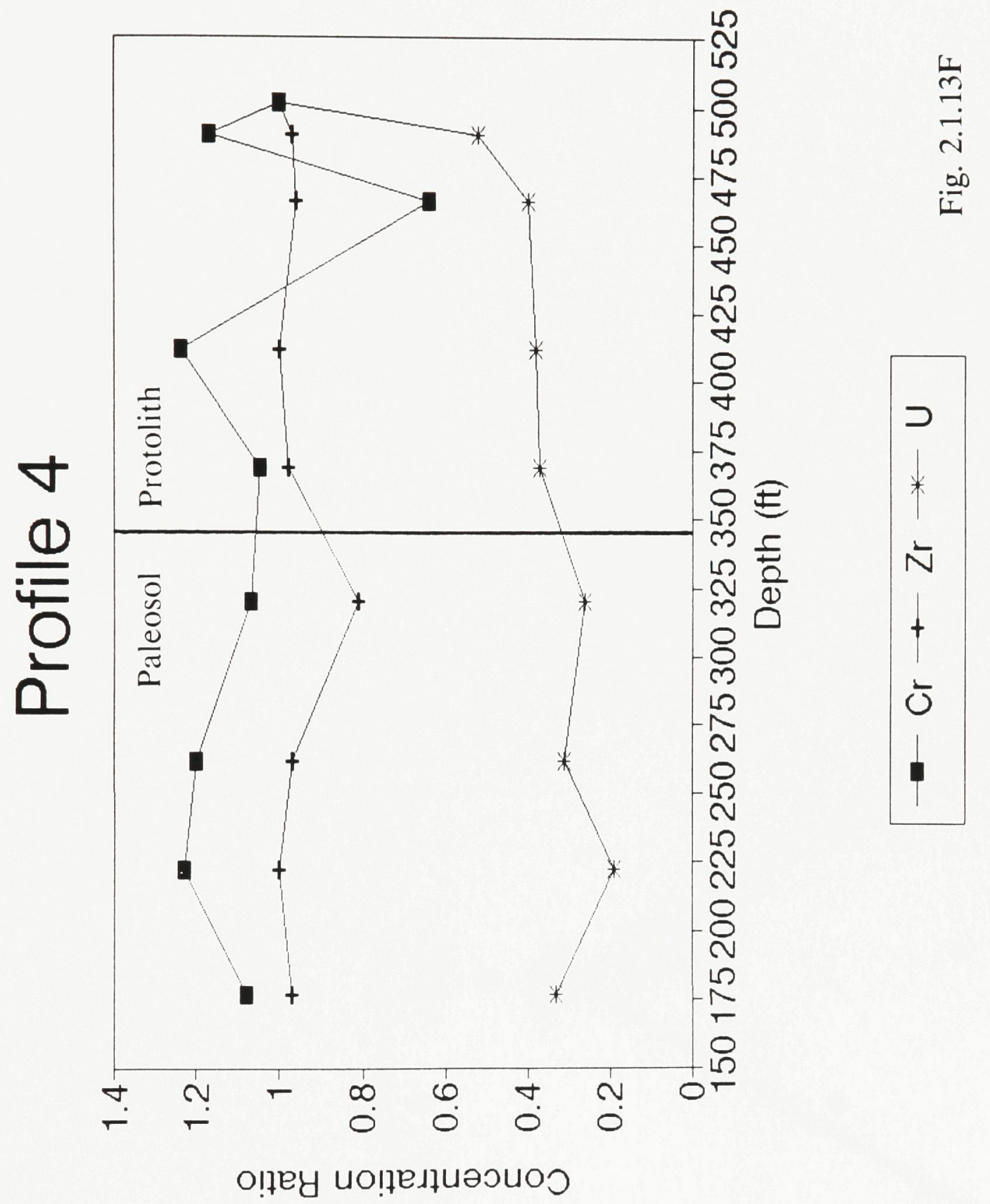



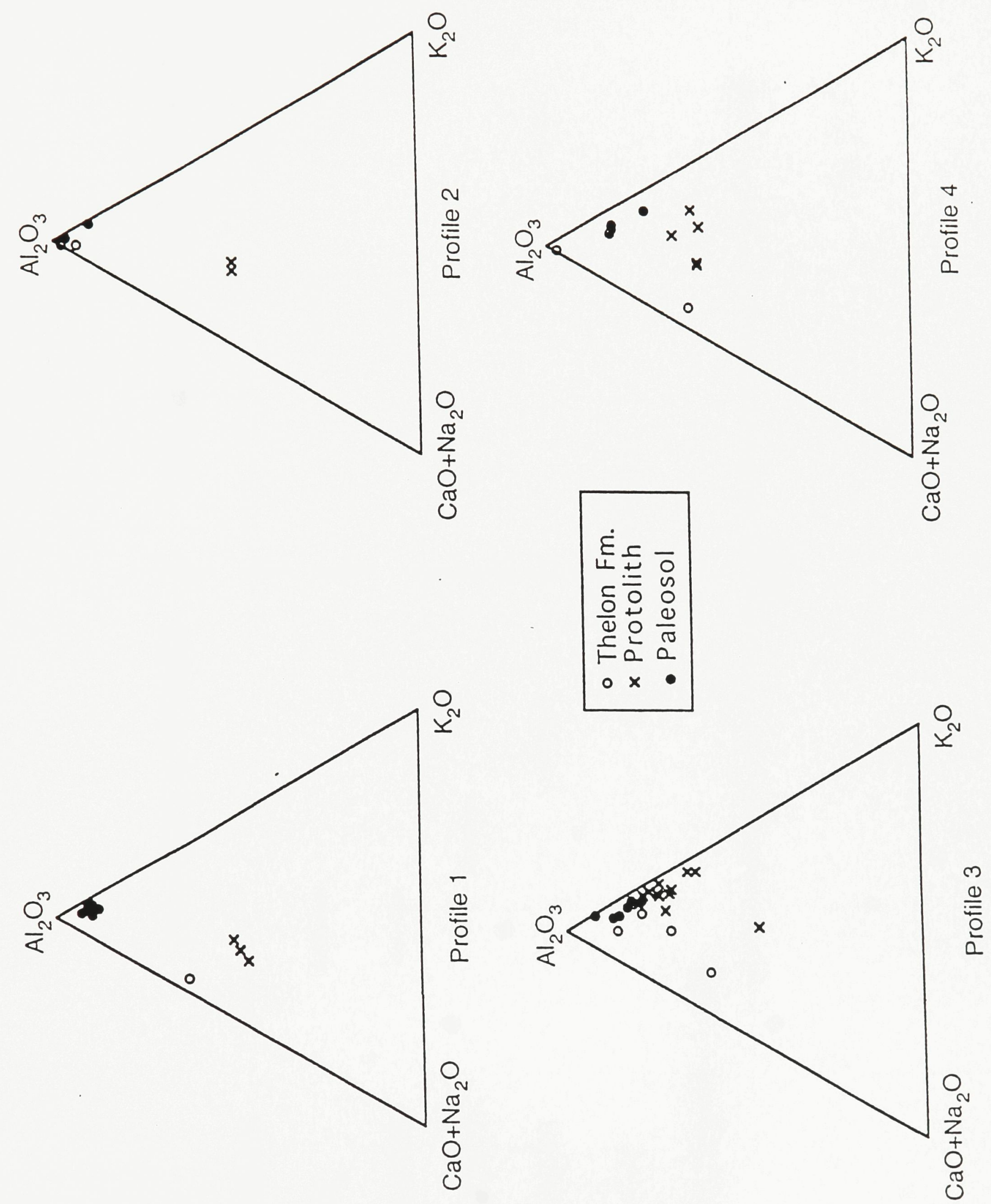


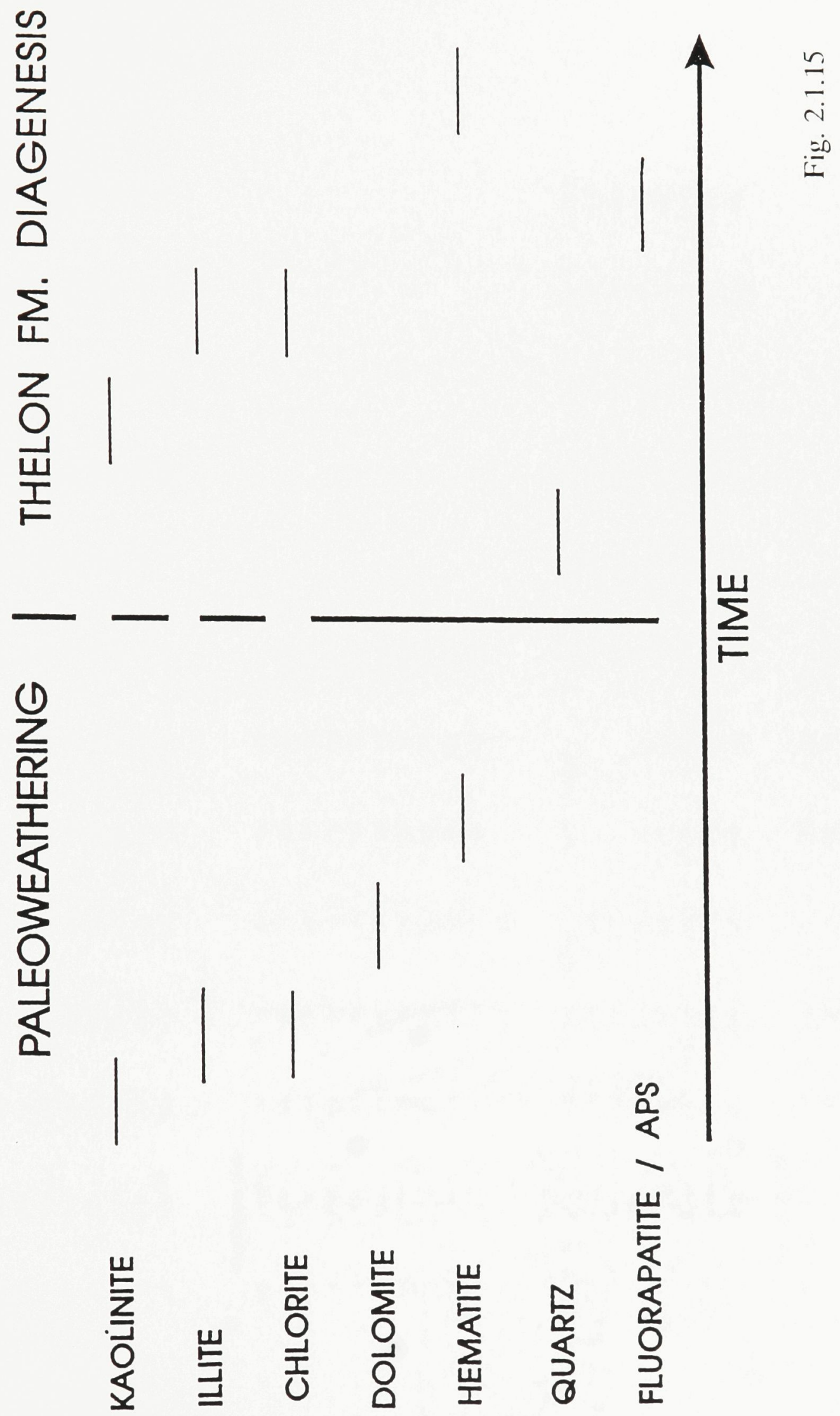


ํํㄴ 3

\&

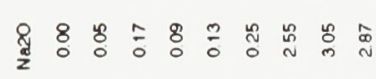

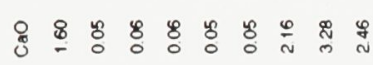

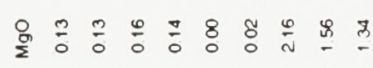

온

串

잉ำ

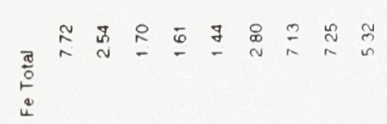

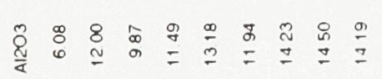

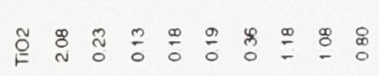

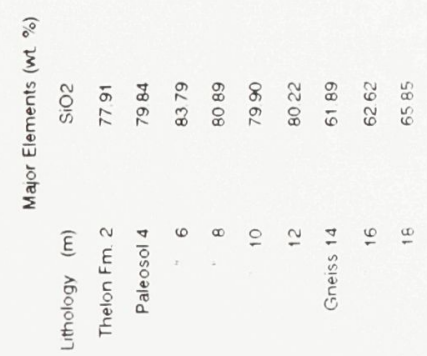

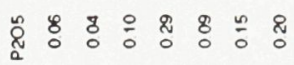

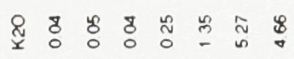

열: 옹 :

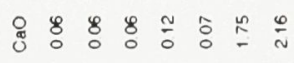

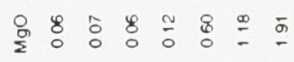

ㅇํㄹ ㅎํำ

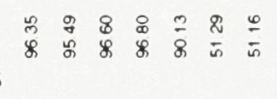

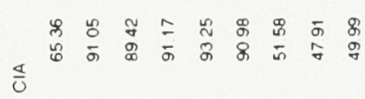

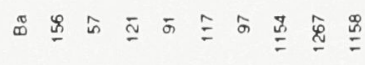
品

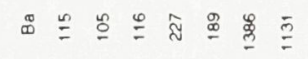
$\stackrel{8}{8}$ 的尽里二 인

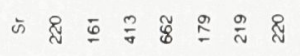

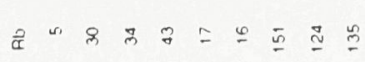

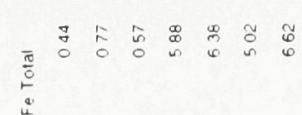
$\cong$

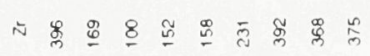

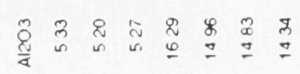

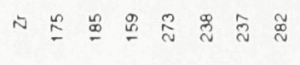

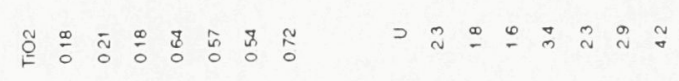

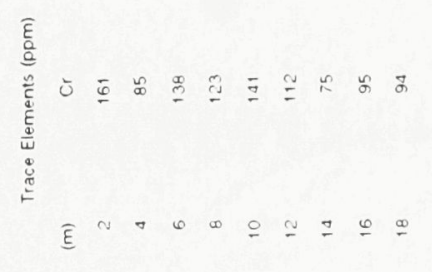

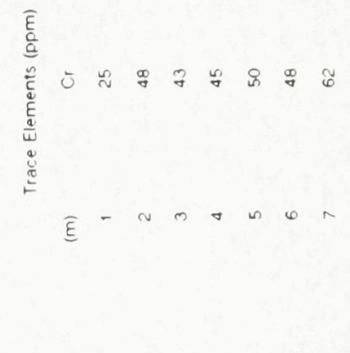




$$
\begin{aligned}
& \text { \& }
\end{aligned}
$$

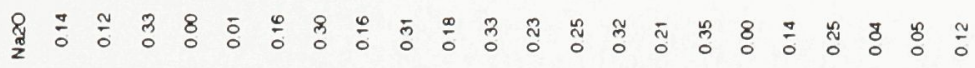

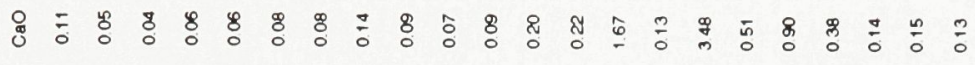

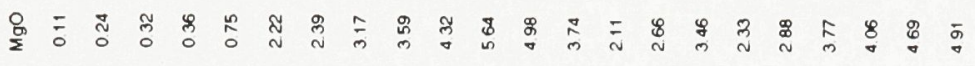

$$
\begin{aligned}
& \text { 岳 }
\end{aligned}
$$

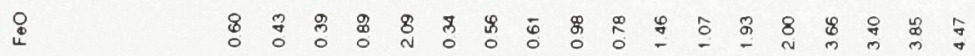

$$
\begin{aligned}
& \text { ¿ }
\end{aligned}
$$

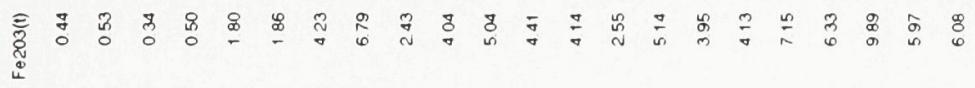

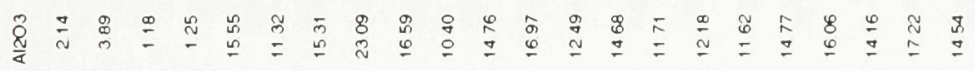

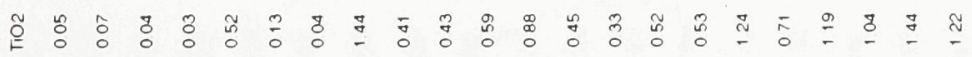

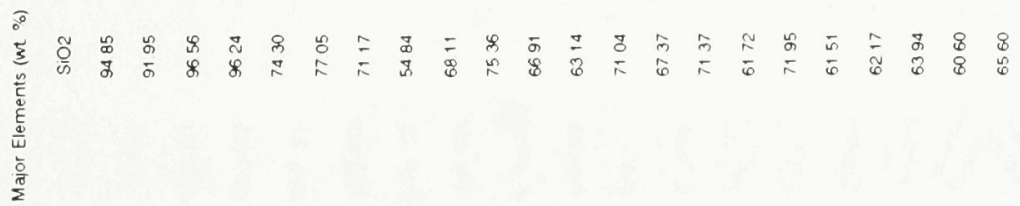

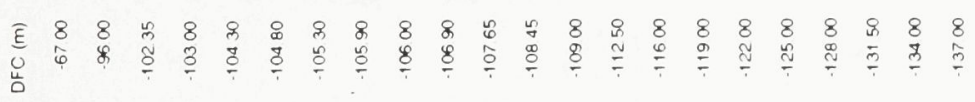

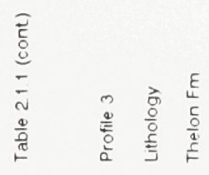




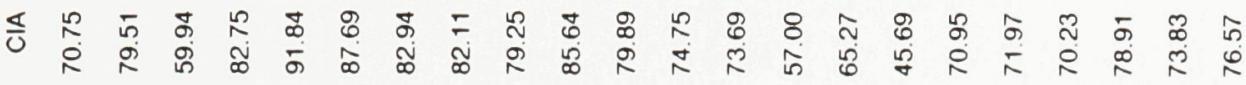

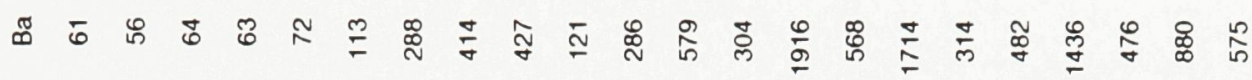

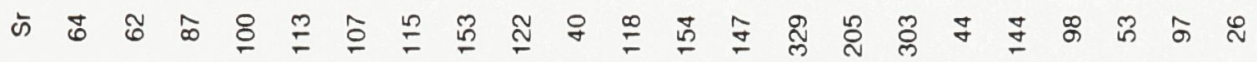

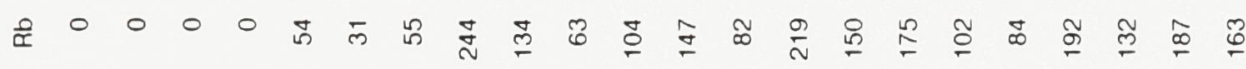

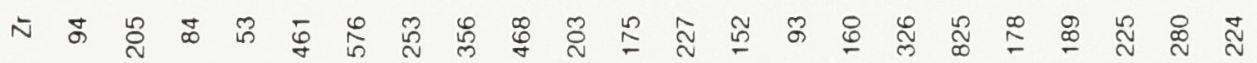

ᄀ

贾

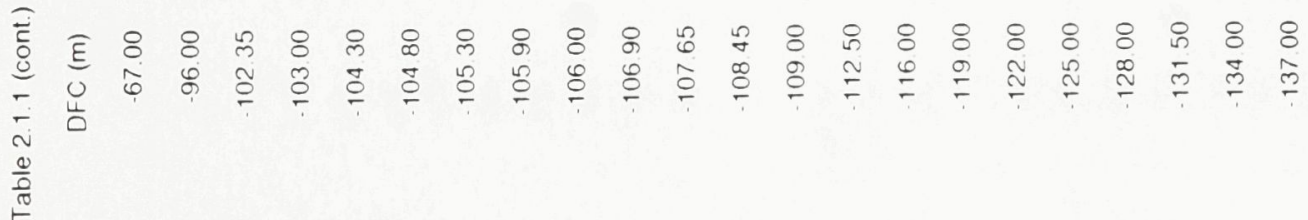




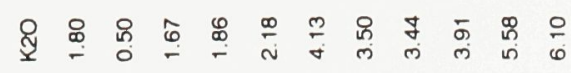

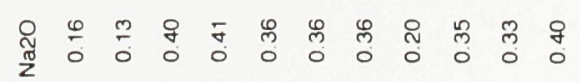

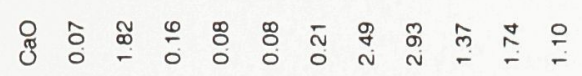

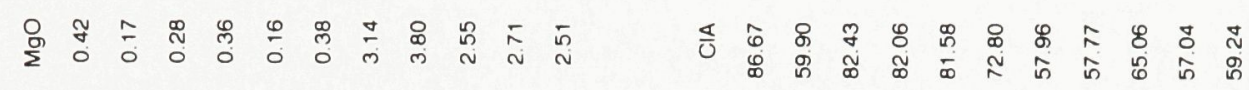

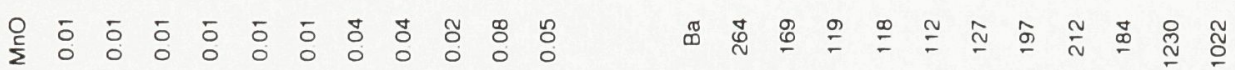

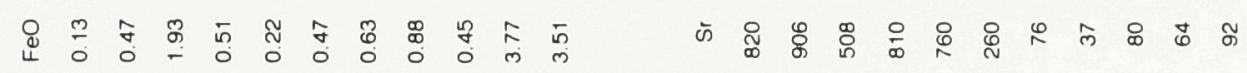

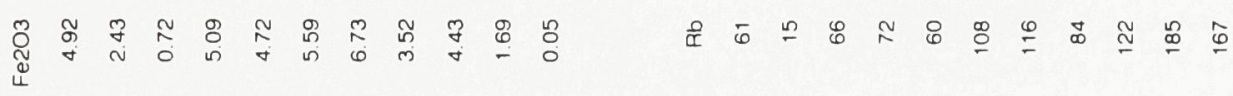

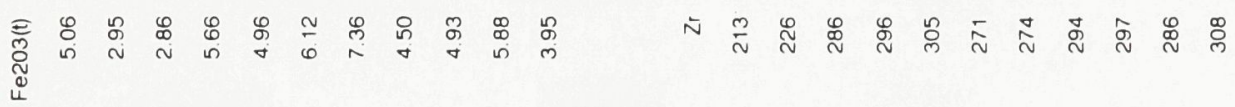

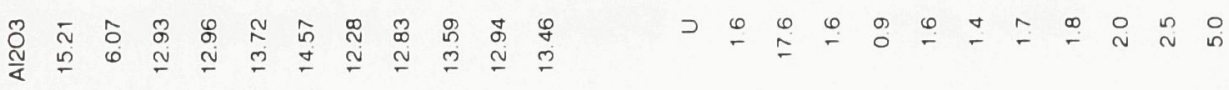

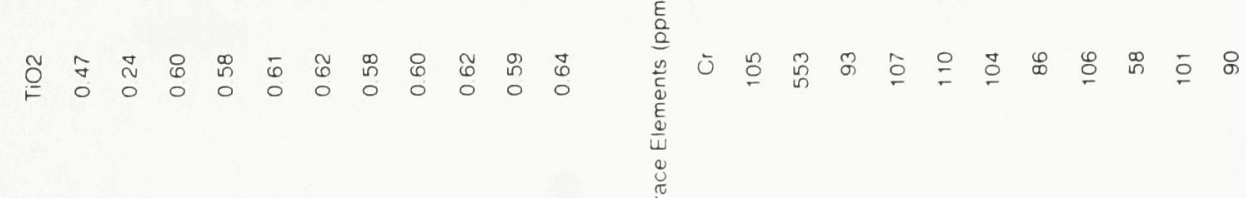

$\circ$

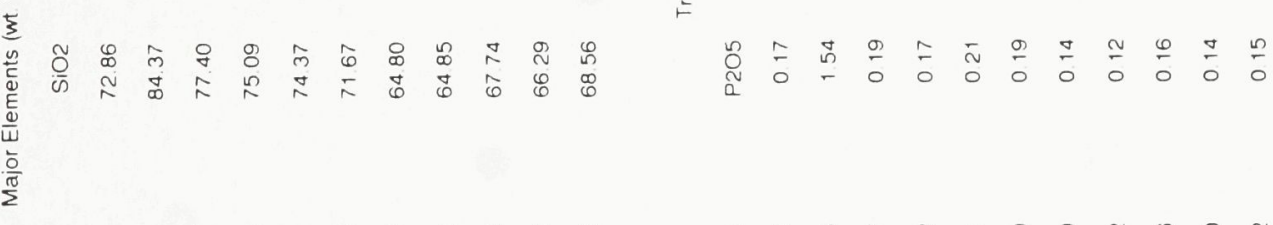

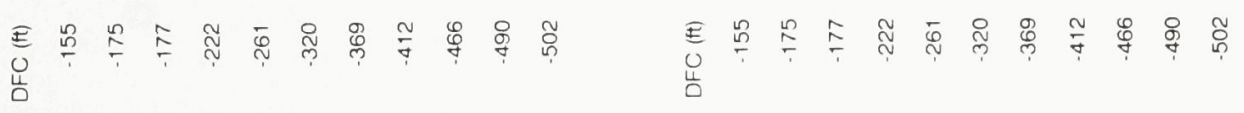


Table 2.1.2 $\mathrm{R}$ values for protoliths in the four Thelon paleosol profiles, and iron loss from weathering using the percent divisions of Holland (1984).

Profile Protolith R \% iron loss

1 granitoid gneiss $0.0447 \quad>40$

2 granite $\quad 0.0385 \quad<20$

3 pelitic gneiss $0.0252>20,<40$

4 semipelitic $\quad 0.0166 \quad<20$ schist 


\section{CHAPTER TWO}

SECTION TWO

PALEOWEATHERING OF THE PITZ FORMATION 


\section{INTRODUCTION}

Paleoweathered felsic volcanic rocks of the Pitz Formation have been studied from two localities three to six kilometres north of Dubawnt Lake, and in the Marjorie Hills approximately $21 \mathrm{~km}$ northwest of Marjorie Lake (Fig. 2.2.1). In all three localities, the Thelon Formation crops out a few metres from the underlying Pitz Formation. In these localities, a subtle colour zonation exists between the least weathered volcanic rock (at the base of metre-scale cliffs and in the central parts of corestones) and the most weathered rock (at the top of the cliffs and in the corestone matrix). Generally, the rock colour grades from dark red (10R 6/2), to grey-red (10R 4/2), to pale red (10R 6/2) with increased weathering.

\section{PHYSICAL WEATHERING}

Two styles of physical weathering are evident in outcrop. Near Dubawnt Lake, a centimetre-scale hackly, polyhedral structure is developed in the felsic volcanic rocks (Fig. 2.2.2), with light brown (5YR 6/4) microfractures separating greyish red purple (5RP 4/2) protolith. The structure resembles incipient ped development (cf. Birkeland, 1984), and may be categorized as very coarse, angular blocky peds. Cutans separating the peds consist of pallid protolith; no illuviated materials (e.g., argillans) are evident. At the Marjorie Hills locality, irregularly distributed centimetre- to decimeter-scale corestone is developed (Fig. 2.2.3). Feldspar phenocrysts can be easily seen in the subrounded and irregular shaped, dark 
red cores. Fewer altered phenocrysts can be seen in the brownish red, sandy textured matrix. In that these corestones are matrix supported and comprise $50 \%$ of the rock, they are similar to Zone II corestone described by Ruxton and Berry (1957), which they suggest represents a mature stage of weathering profile development.

At one locality northwest of Dubawnt Lake, a crude horizontal parting persists throughout the outcrop (Fig. 2.2.4). This horizontal parting, together with the stylocumulates observed in profiles a few kilometres away, are considered to be compaction features related to accumulation of the Thelon Formation sediments on the structurally weakened paleosol (Gall and Donaldson, 1990).

\section{MINERAL ALTERATION}

The samples of Pitz Formation are massive rhyolite to rhyodacite, consisting of quartz and feldspar phenocrysts within a dark red groundmass composed of feldspar microlites, quartz, apatite, opaque minerals, and minor biotite and zircon. The phenocrysts, up to one centimetre in length, are anhedral, with quartz displaying resorbed margins. In the most hackly weathered, polyhedral-structured samples, quartz phenocrysts remain relatively unaltered but the feldspar phenocrysts have altered to kaolinite and illite. Some illite crystals have grown into the kaolinite. Cleavage is evident in some feldspar phenocrysts but albite twinning was seen only in one grain. The lack of twinning and paucity of interference figures made it impossible to determine the original composition of the feldspars. 
Apart from replacing feldspar phenocrysts, fibrous illite is also present in the groundmass, and masks the groundmass minerals (Fig. 2.2.5). Minor amounts of chlorite has replaced biotite; minor amounts of dolomite have replaced a few feldspar phenocrysts and form irregular patches in the groundmass. Opaque hematite cement forms disseminated patches which cut other alteration minerals or fills rare fractures. Quartz-filled veinlets cut all minerals, including hematite. X-ray diffractograms of the $<2 \mu \mathrm{m}$ fraction from each sample indicate the presence of biotite, illite, trioctahedral chlorite, kaolinite, alkali feldspar, quartz, and hematite.

\section{GEOCHEMICAL DATA}

Eight samples from the two localities north of Dubawnt Lake were analysed (Table 2.2.1). No clear trends emerge when major oxide and trace element abundances are plotted against apparent vertical depth below the Matonabbee unconformity. This suggests that even the apparently fresh Pitz Formation samples from these two localities have been altered by paleoweathering. To determine which elements may have been lost or gained during paleoweathering, compared to fresh protolith, the eight analyses were compared to the Pitz Formation rhyolite analyses of Blake (1980) and Booth (1983) from localities within the Baker Lake Basin, as well as with Wharton Group granite from Dubawnt Lake (Peterson, in prep), which is considered to be the coeval intrusive equivalent of the Pitz Formation alkali volcanic rocks (Gall et al., 1992; Peterson, in prep). To date, these analyses from Baker Lake Basin and Dubawnt Lake are the only published analyses of the 
unweathered protolith which are available for comparison. One other sample of unweathered rhyolite was collected for comparison from the north shore of Dubawnt Lake (sample QG-92-27, Table 2.2.1).

Table 2.2.1 shows that $\mathrm{SiO}_{2}$ is abundant in both unweathered and weathered samples, suggesting that $\mathrm{SiO}_{2}$ has been relatively unaffected by paleoweathering. For this reason, Harker plots, comparing various elements against $\mathrm{SiO}_{2}$, have been used to assess the effects of paleoweathering on major oxides and trace elements. The resulting plots are shown in Figures 2.2.6A to 2.2.6Q.

In many of the Harker plots (Figs. 2.2.6A to 2.2.6Q), the analyses of Booth (1983) and Peterson (in prep) plot close together, and are viewed as representing the element abundance in unweathered Wharton Group rhyolite and granite. Blake (1980) reported that one sample (76 LAAT253-1) contains kaolinite. The presence of kaolinite as well as the variable element behaviour and high CIA, indicate that this sample is weathered.

A negative sloping linear array between $\mathrm{SiO}_{2}$ and $\mathrm{Al}_{2} \mathrm{O}_{3}$ indicates that aluminum loss in some weathered samples results in a relative silica increase. $\mathrm{TiO}_{2}$, $\mathrm{MgO}, \mathrm{P}_{2} \mathrm{O}_{5}, \mathrm{Cr}, \mathrm{Ba}$ and $\mathrm{CIA}$ values are, on average, higher in weathered samples compared to unweathered samples. Conversely, $\mathrm{FeO}, \mathrm{Na}_{2} \mathrm{O}, \mathrm{Rb}$ and $\mathrm{U}$ are depleted in weathered samples. $\mathrm{K}_{2} \mathrm{O}$ in the weathered samples is either enriched or depleted 
compared to the unweathered samples. The remaining major oxides and trace element abundances are similar to the unweathered samples.

\section{DISCUSSION AND CONCLUSIONS}

It is apparent that the nature of paleoweathering of the Pitz Formation rhyolite is different, both physically and chemically, from that shown in Profiles 1 to 4. Physically, primary weathering structures in the form of peds and corestone are well developed. Chemically, a general depletion of elements with increased weathering, as seen in Profiles 1 to 4 , is not apparent when geochemical analyses of weathered Pitz Formation rhyolite are compared to unweathered Pitz Formation and coeval granite. These discrepancies, and the absence of fresh protolith in the outcrop localities, suggest that (a) the weathered Pitz Formation outcrops represent areas which were more highly weathered (perhaps higher in the weathering profile); and/or (b) the behaviour of elements during weathering was variable.

In the weathered Pitz Formation samples, slight relative increases in $\mathrm{TiO}_{2}, \mathrm{Cr}$ and $\mathrm{P}_{2} \mathrm{O}_{5}$ in the weathered rhyolite samples may reflect their association with resistant opaque metaliic minerals and apatite, and consequent immobility during weathering. The high $\mathrm{K}_{2} \mathrm{O}$ values in some samples (Table 2.2.1) can be correlated to increased amounts of illite in the weathered rhyolite samples. It is not clear why 
some weathered rhyolite samples have elevated barium. One possible explanation is that, because it is possible for barium to substitute for potassium in micas (Norrish, 1975; Nesbitt et al., 1980), and because the samples with increased barium are the same as those with elevated potassium values, the increases in barium may be related to illitization. The depletion of a few elements in weathered samples may be due to element leaching from minerals during oxidative weathering (e.g., U), or redox transformation (e.g., $\mathrm{FeO}$ to $\mathrm{Fe}_{2} \mathrm{O}_{3}$ ). 


\section{REFERENCES}

Birkeland, P.W. 1984. Pedology, weathering, and geomorphological research. Oxford University Press, 285 p.

Blake, D.H. 1980. Volcanic rocks of the Paleohelikian Dubawnt Group in the Baker Lake - Angikuni Lake area, District of Keewatin, N.W.T. Geological Survey of Canada, Bulletin 309, 39 p.

Booth, G.W. 1983. The petrology and geochemistry of the Pamiutuq Lake Batholith, Northwest Territories. M.Sc. thesis, University of Toronto, Toronto, $168 \mathrm{p}$.

Gall, Q. and Donaldson, J.A. 1990. The sub-Thelon Formation paleosol, Northwest Territories. Geological Survey of Canada, Paper 90-1C, pp. 271-277.

Gall, Q., Peterson, T.D., and Donaldson, J.A. 1992. A proposed revision of Early Proterozoic stratigraphy of the Thelon and Baker Lake basins, Northwest Territories. Geological Survey of Canada, Paper 92-1C, pp. 129-137.

Nesbitt, H.W., Markovics, G. and Price, R.C. 1980. Chemical processes affecting alkalies and alkaline earths during continental weathering. Geochimica et Cosmochimica Acta, v. 44, pp. 1659-1666. 
Norrish, K. 1975. Geochemistry and mineralogy of trace elements. In: Trace elements in soil-plant-animal systems. Edited by D.J.D. Nicholas and A.R. Egan. Academic Press Inc., pp. 55-81.

Peterson T.D. in prep. Geology of the Dubawnt Lake area. Geological Survey of Canada, Bulletin.

Ruxton, B.P. and Berry, L. 1957. Weathering of granite and associated erosional features in Hong Kong. Bulletin of the Geological Society of America, v. 68, pp. $1263-1292$. 


\section{FIGURE CAPTIONS}

Fig. 2.2.1 Geologic map showing the three localities where paleoweathered Pitz Formation rocks were sampled near profile two (map A) and profile one (map B). Geology based on LeCheminant et al. (1983), Peterson et al. (1989), and field work in 1989 and 1992 by the author.

Fig. 2.2.2 Hackly, polyhedral ped structure in paleoweathered Pitz Formation rhyolite. Top scale on card in centimetres.

Fig. 2.2.3 Corestones (bound by arrows) surrounded by paler, in-situ weathered matrix. Lens cap above centre is $6 \mathrm{~cm}$ in diameter.

Fig. 2.2.4 Crude horizontal partings (arrows) developed in paleoweathered Pitz Formation feldspar- and quartz-phyric rhyolite. Person for scale.

Fig. 2.2.5 Feldspar phenocryst (F) and groundmass partly relaced by fibrous illite (I). Hematite $(\mathrm{H})$ has subsequently formed on iron-rich minerals and illite. Paleoweathered Pitz Fm. sample. $0.5 \mathrm{~mm}$ bar scale.

Figs. 2.2.6A to 2.2.6Q. Harker plots for major oxide and trace elements comparing paleoweathered rhyolite samples from the Pitz Formation (Gall, Blake 76LAAT2531), to unweathered Pitz Formation rhyolite (Blake 76LAAT349-1, Booth) and 


$$
2-2-11
$$

unweathered coeval Wharton Group granite (Peterson). Sample analyses shown in Table 2.2.1. 


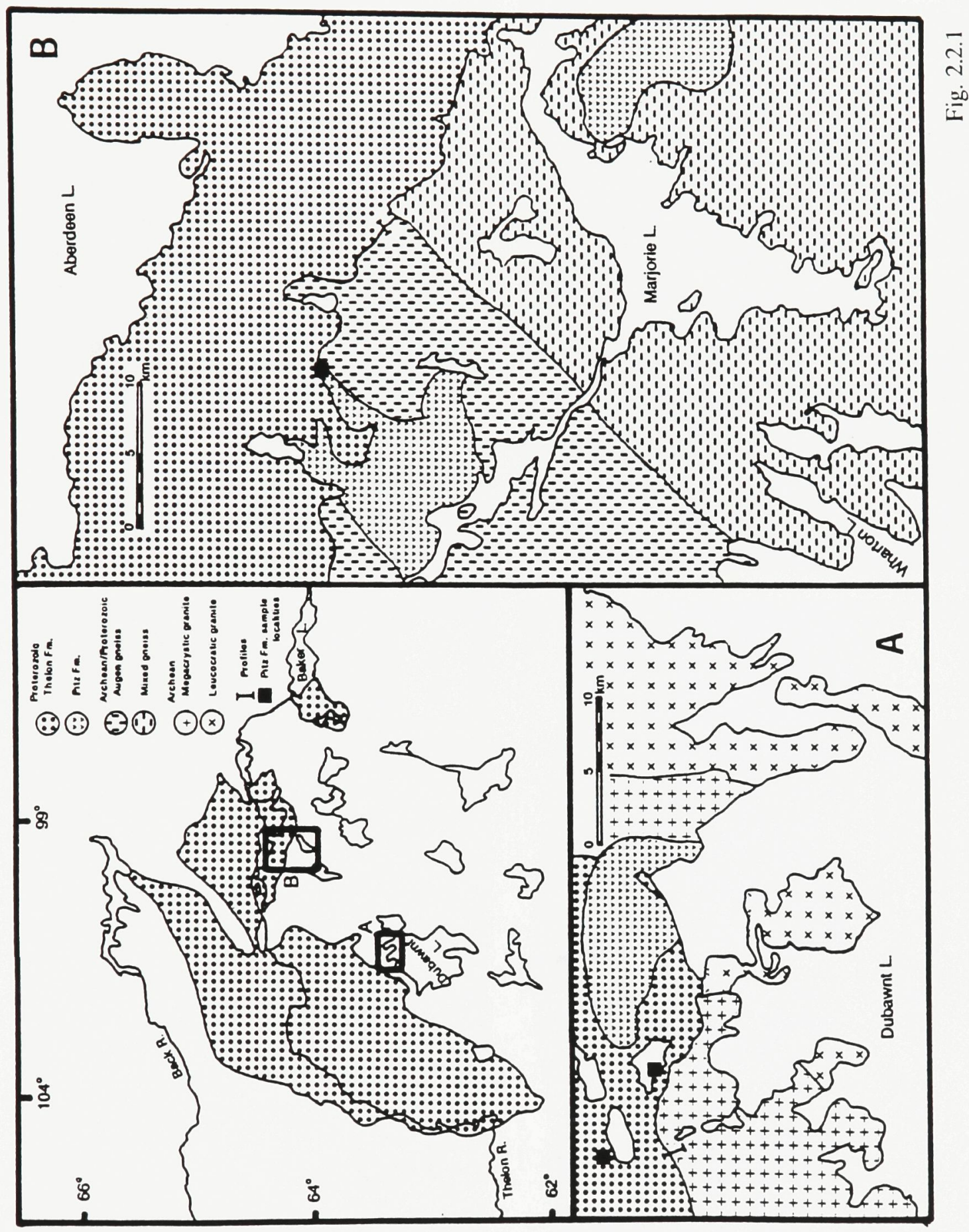



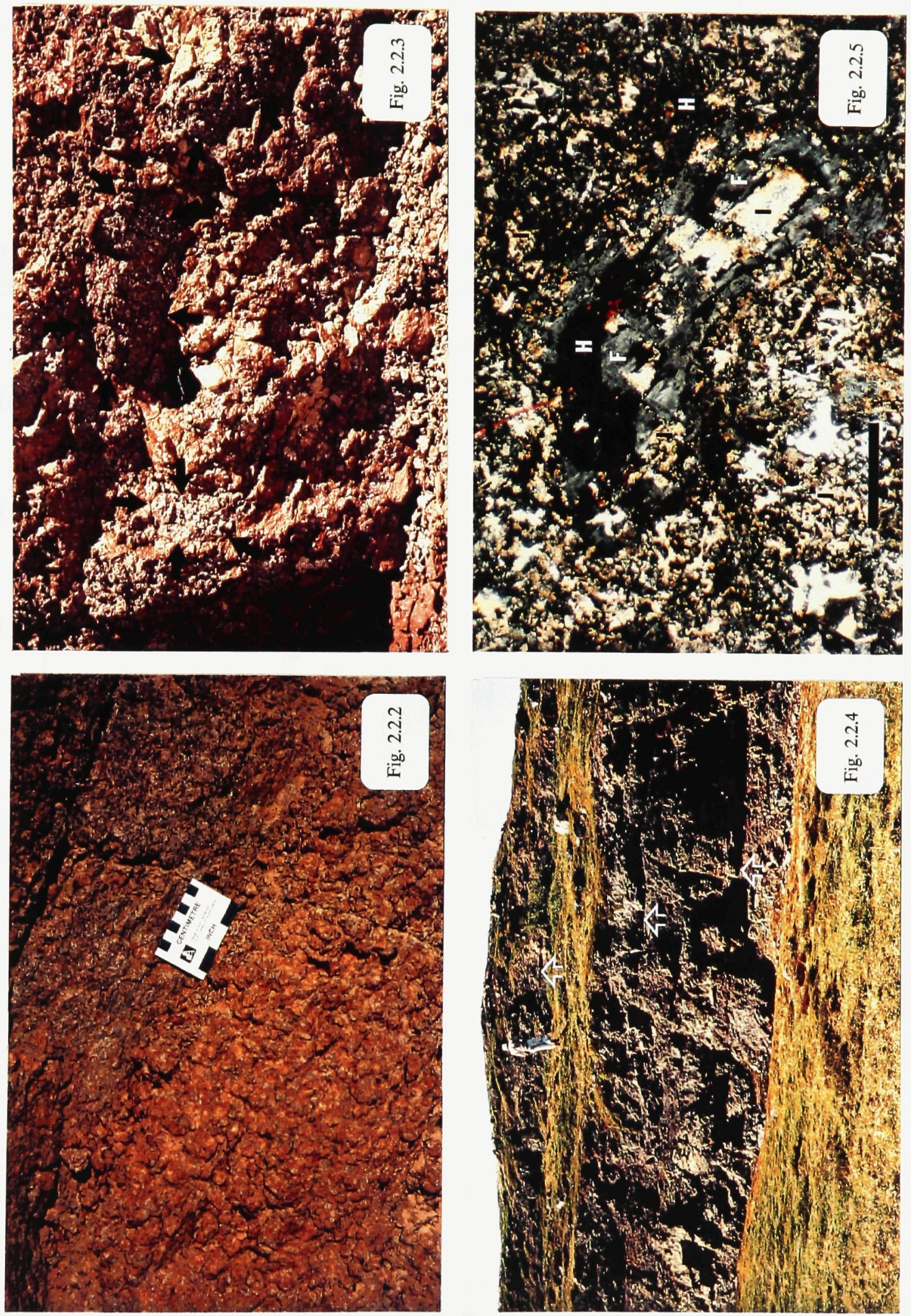


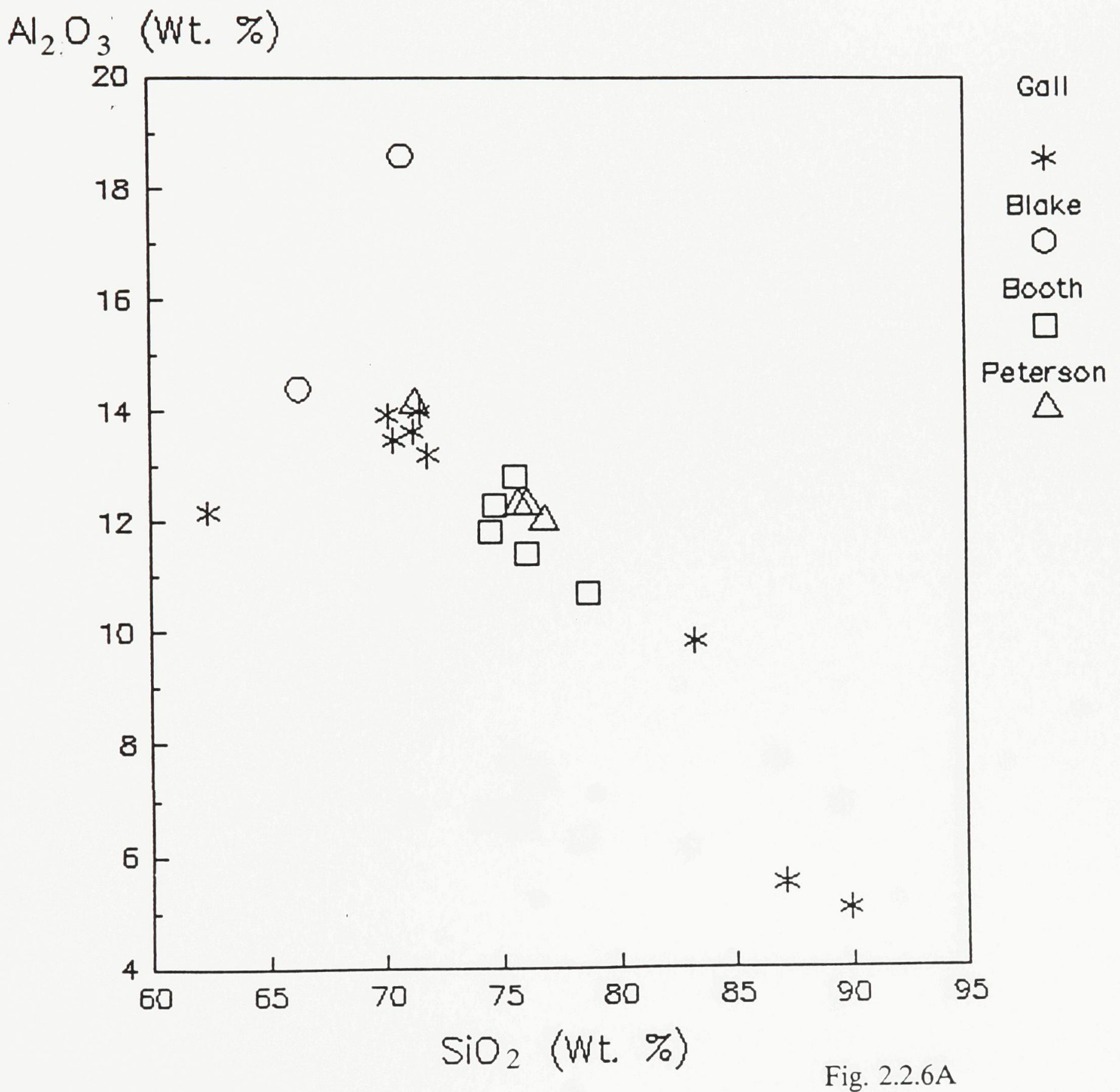


$\mathrm{TiO}_{2}$ (Wt. \%)

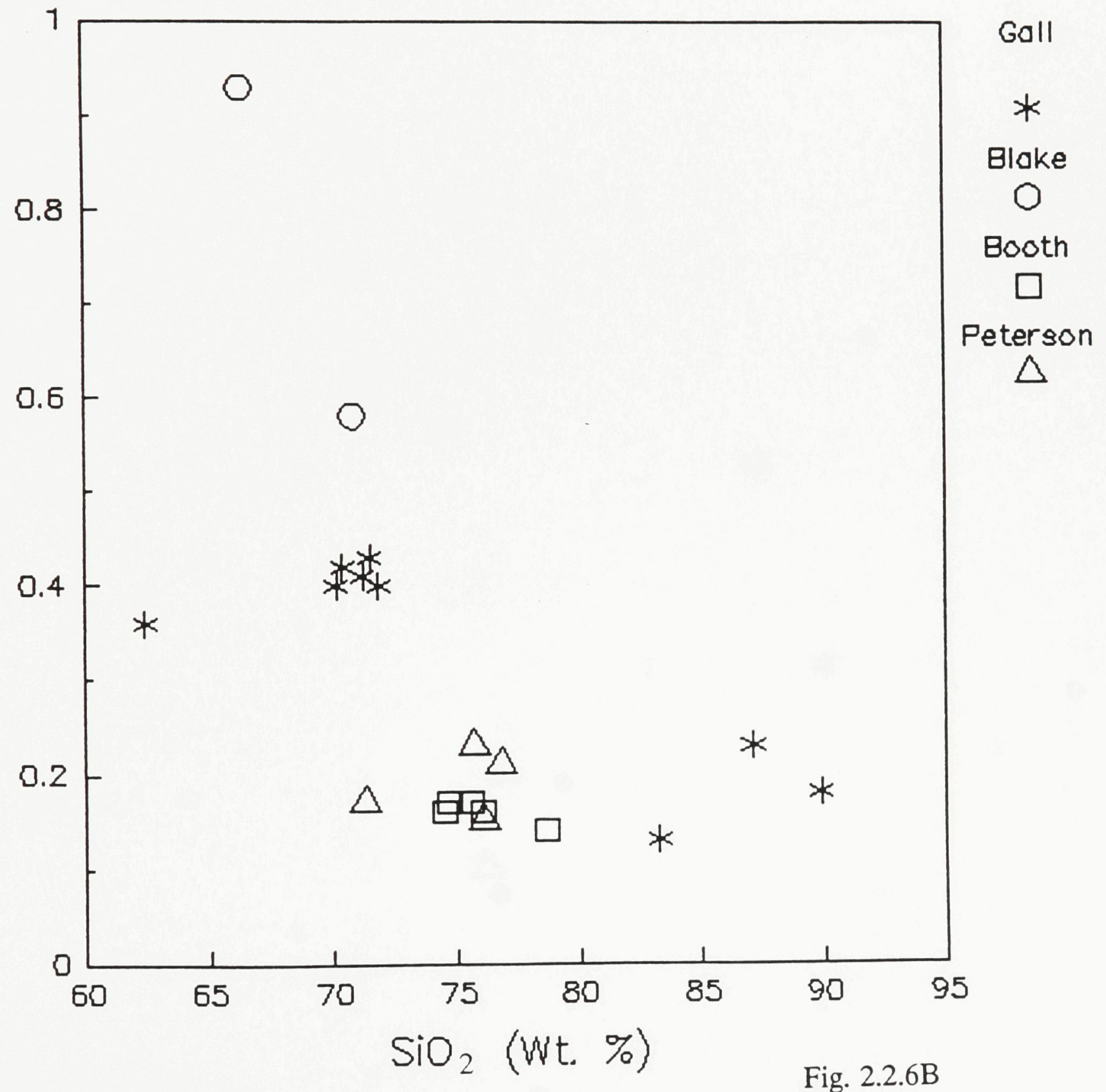




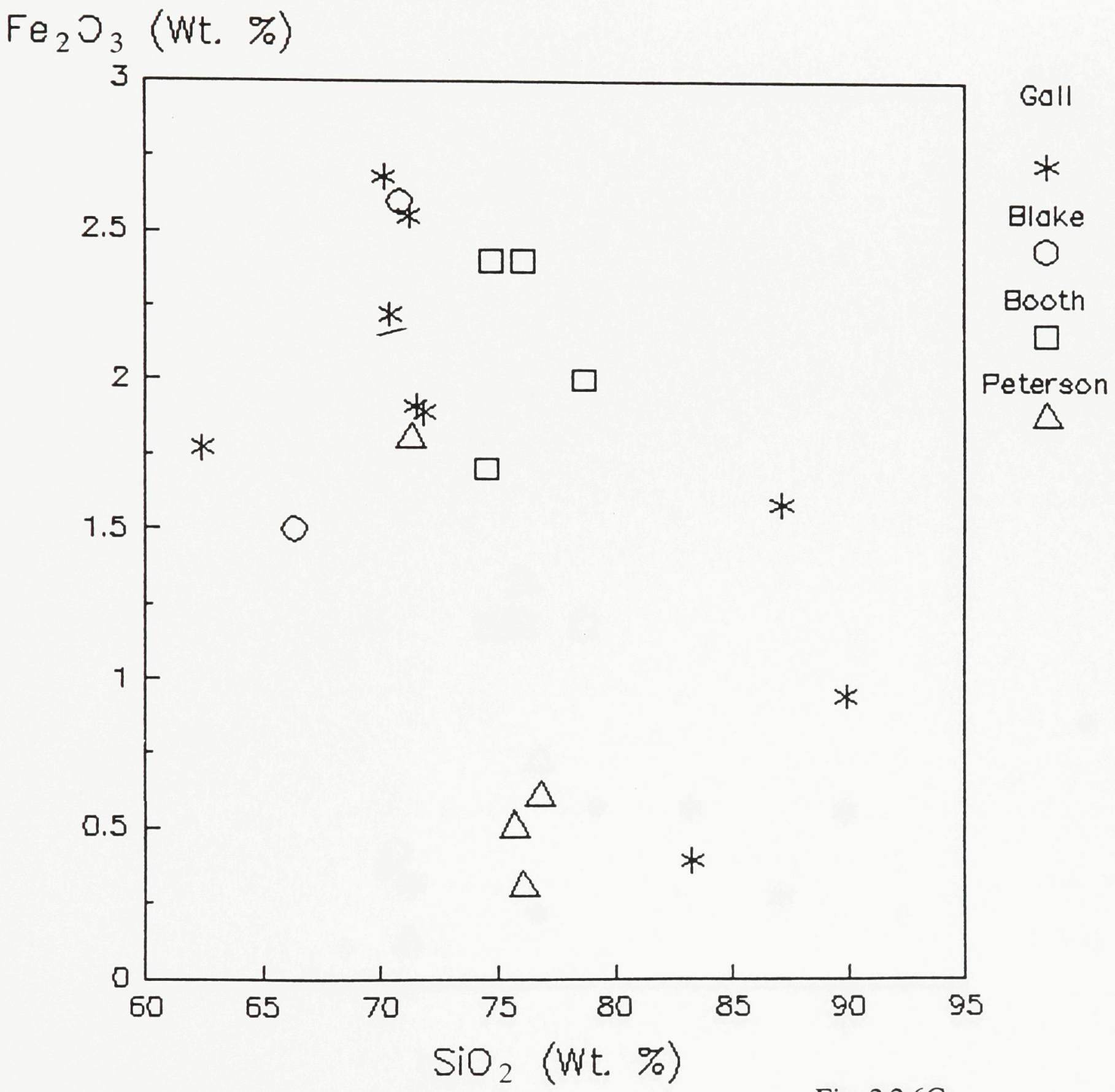

Fig. 2.2.6C 
FeO (Wt. \%)

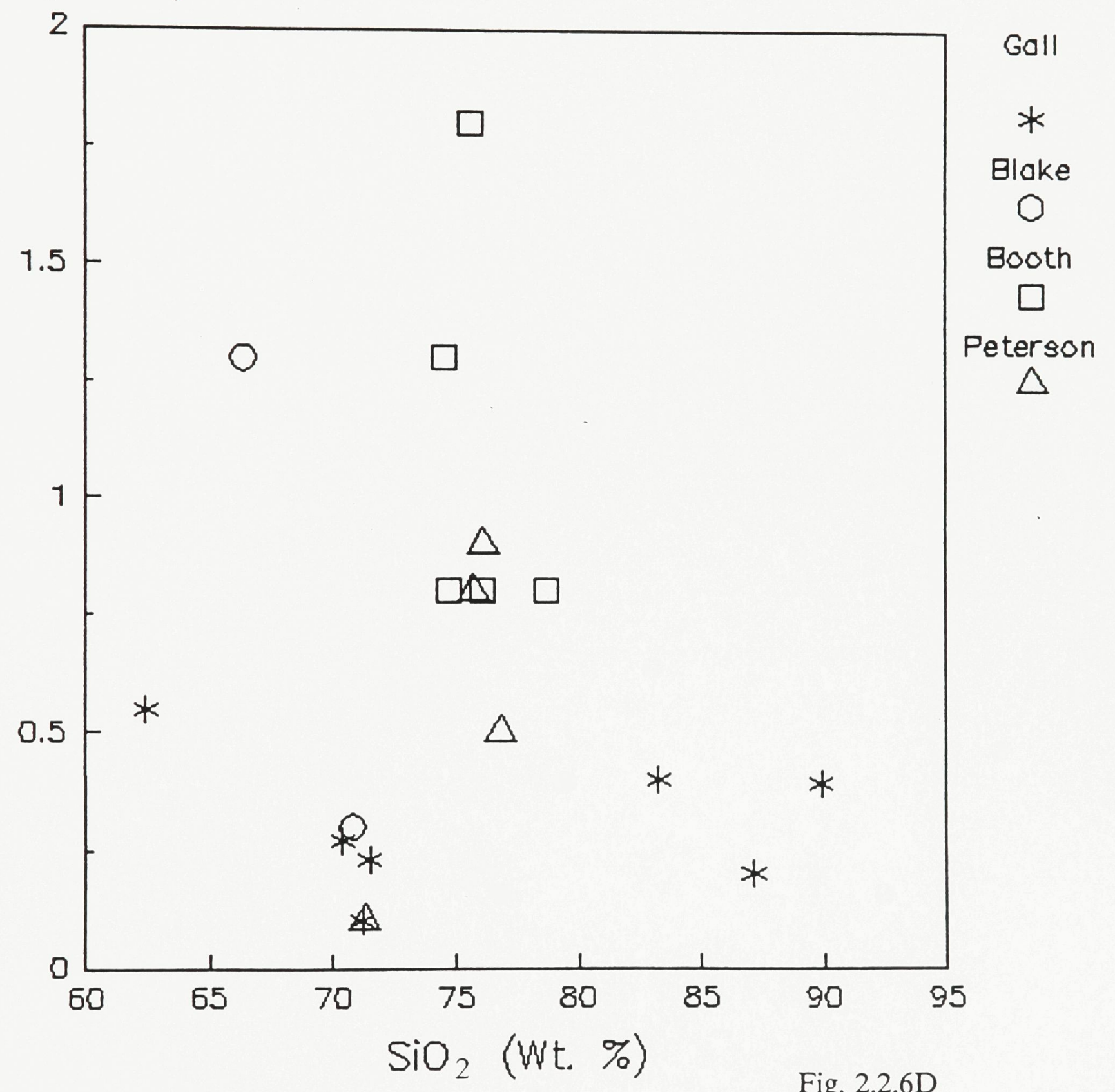

Fig. 2.2.6D 
$\mathrm{MnO}$ (wt. \%)

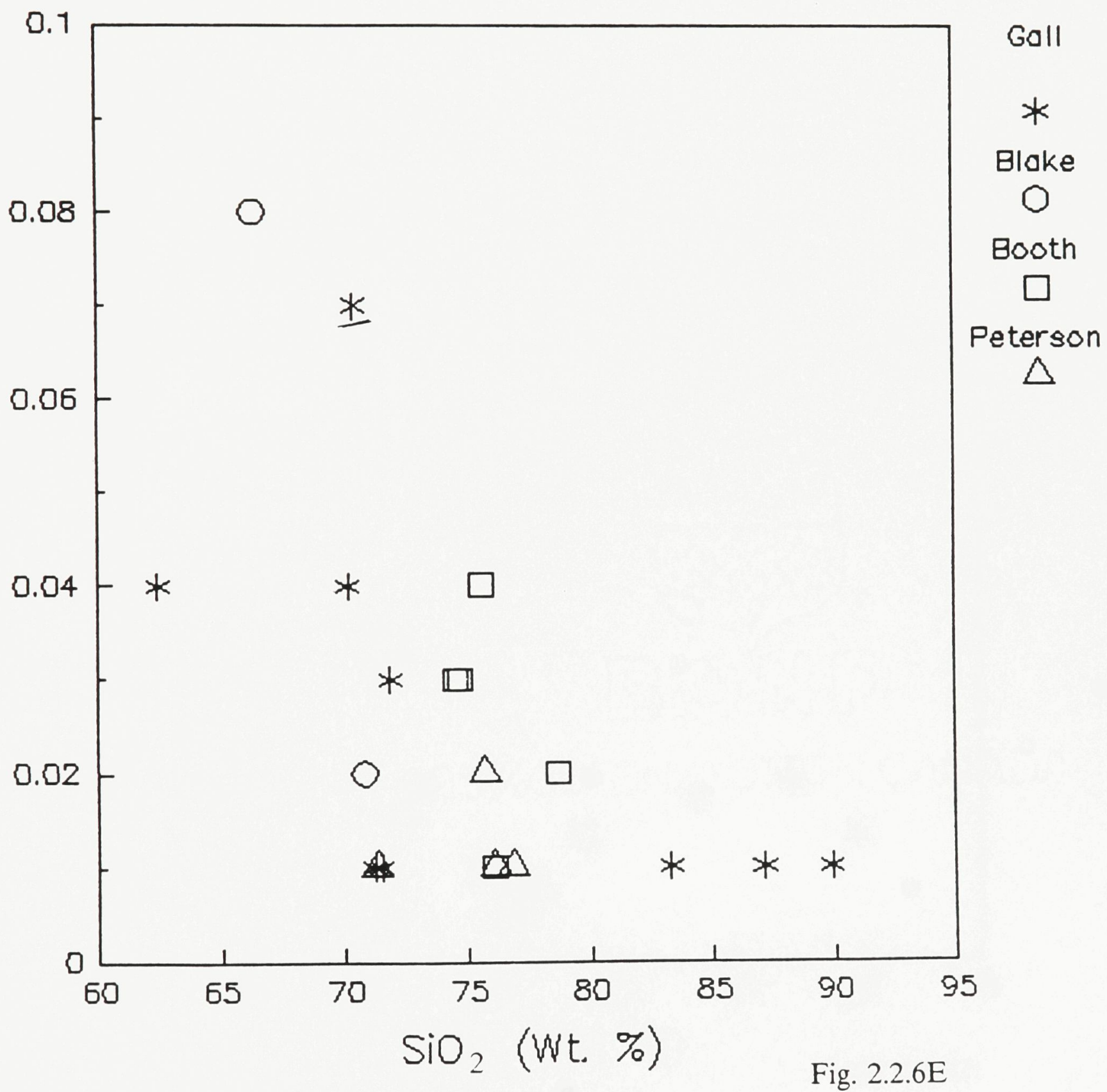


MgO (Wt. \%)

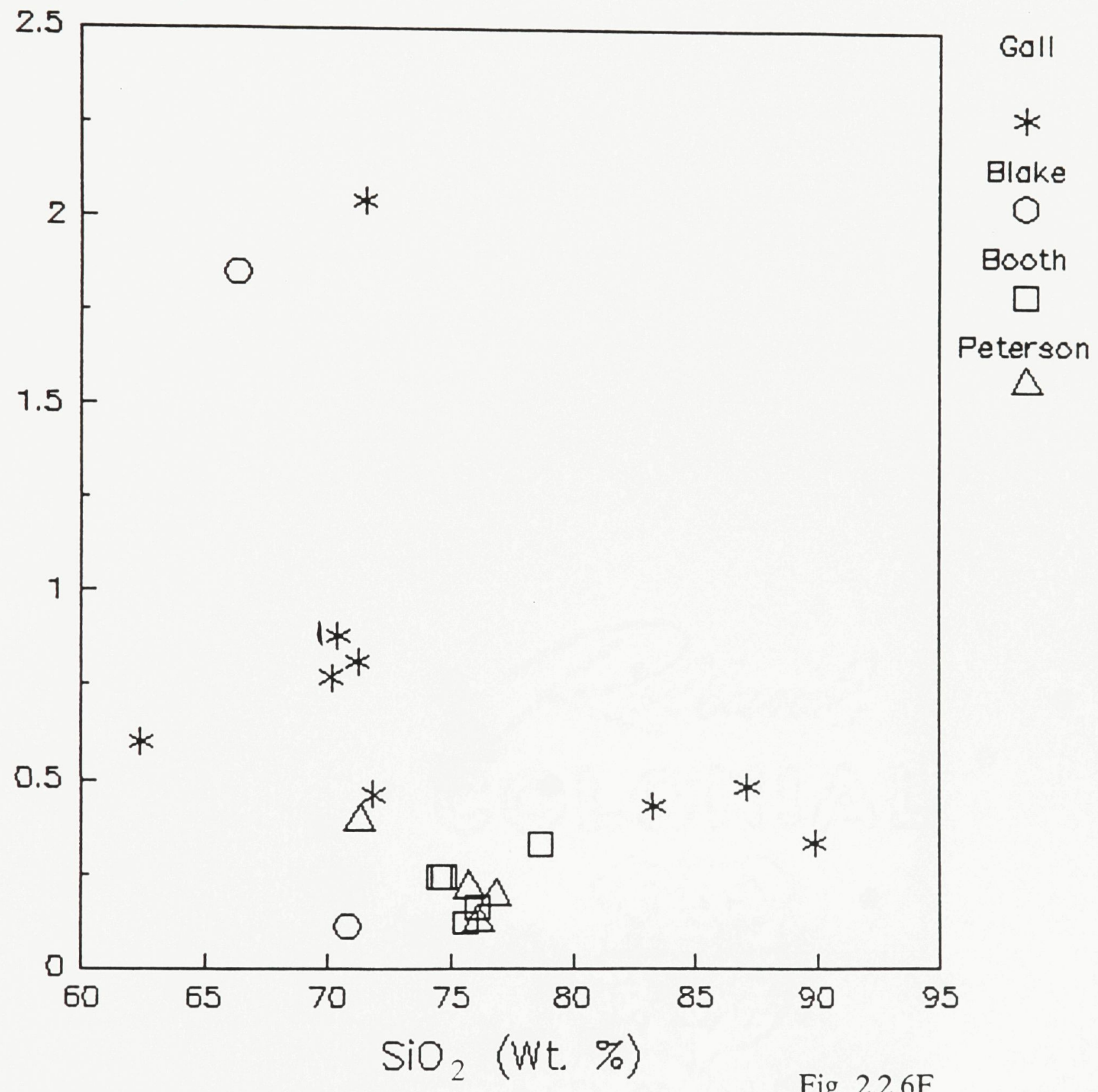

Fig. 2.2.6F 
$\mathrm{CaO}$ (wt. \%)

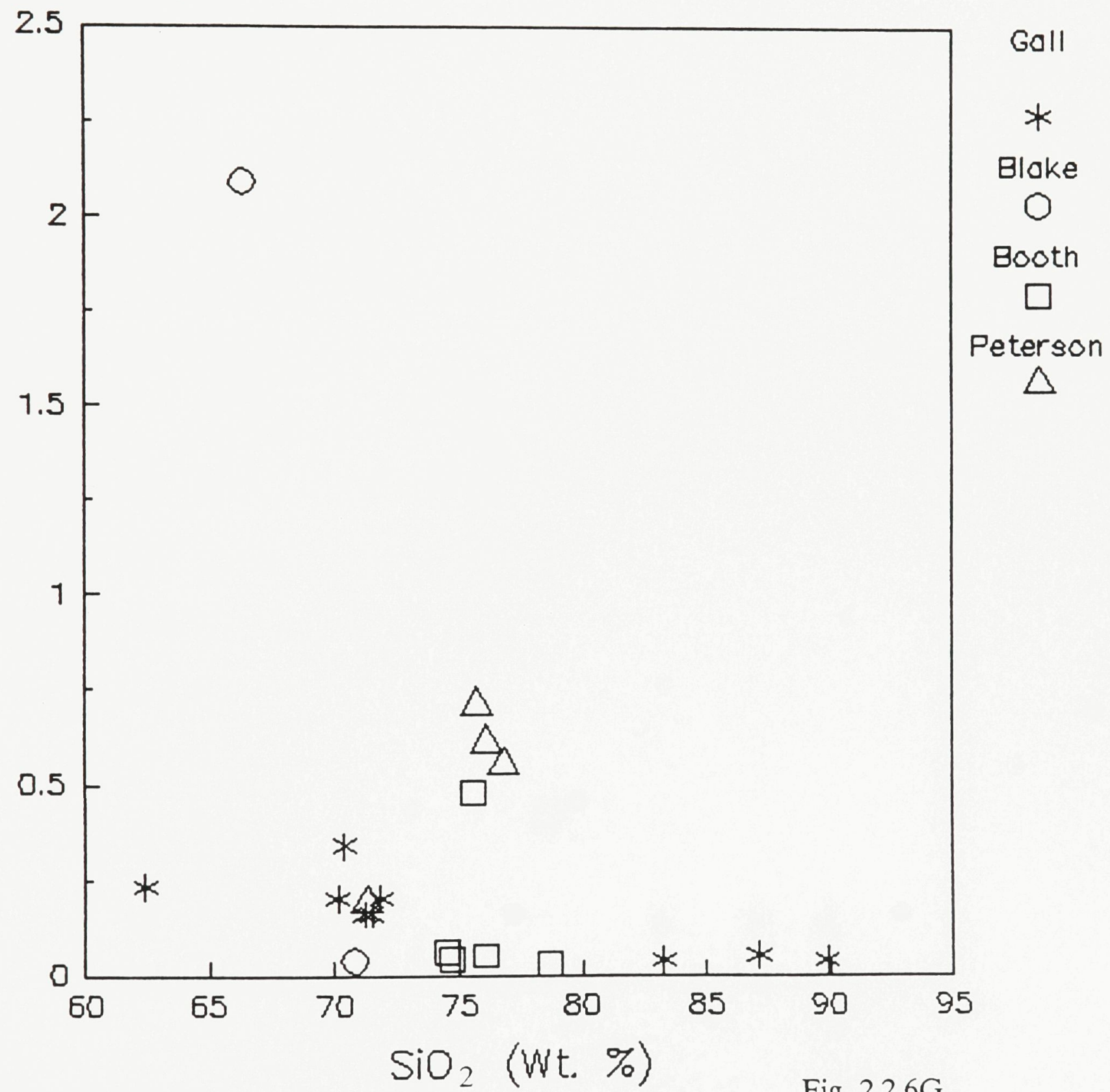

Fig. 2.2.6G 
$\mathrm{Na}_{2} \mathrm{O}$ (wt. \%)

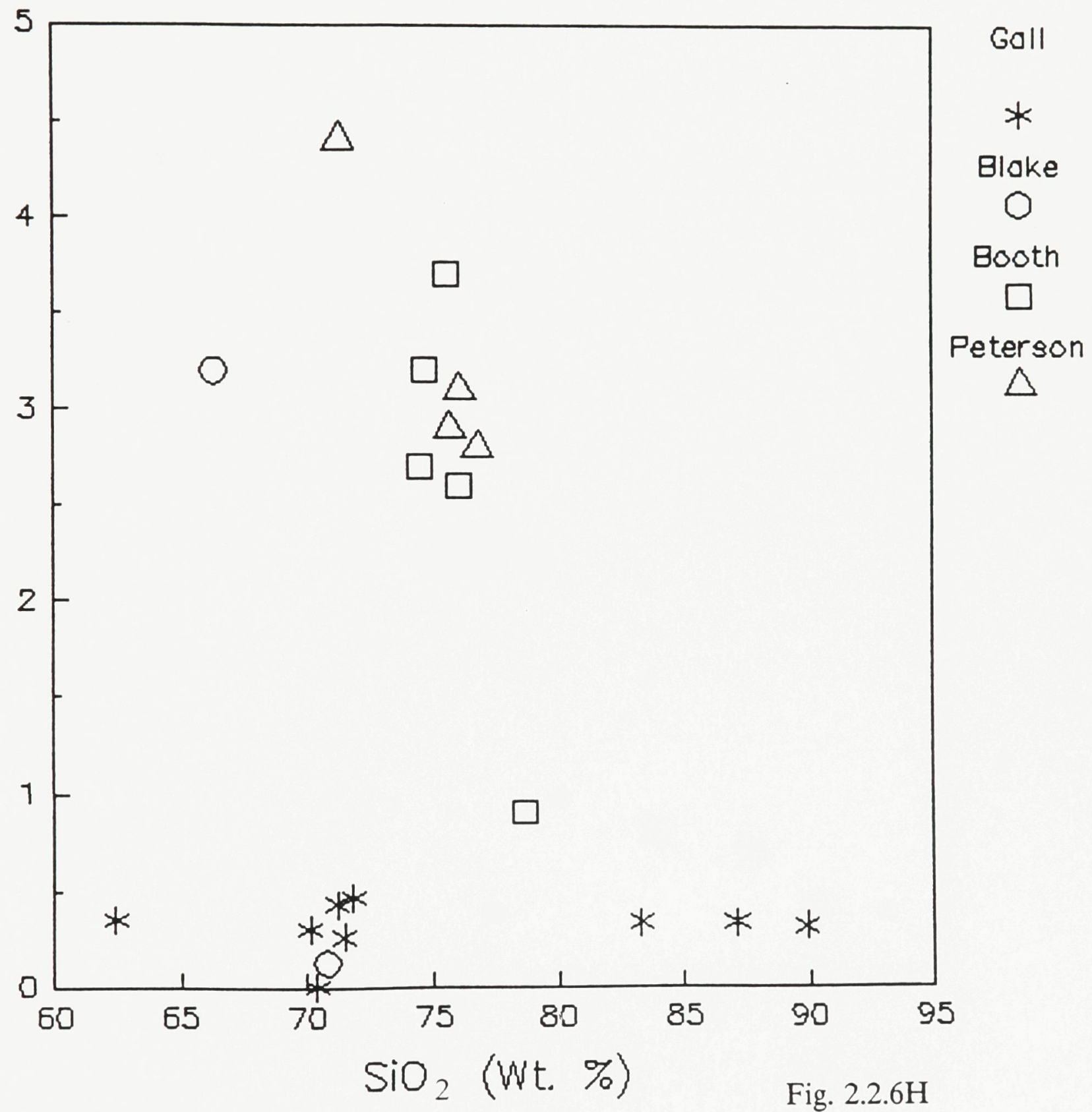




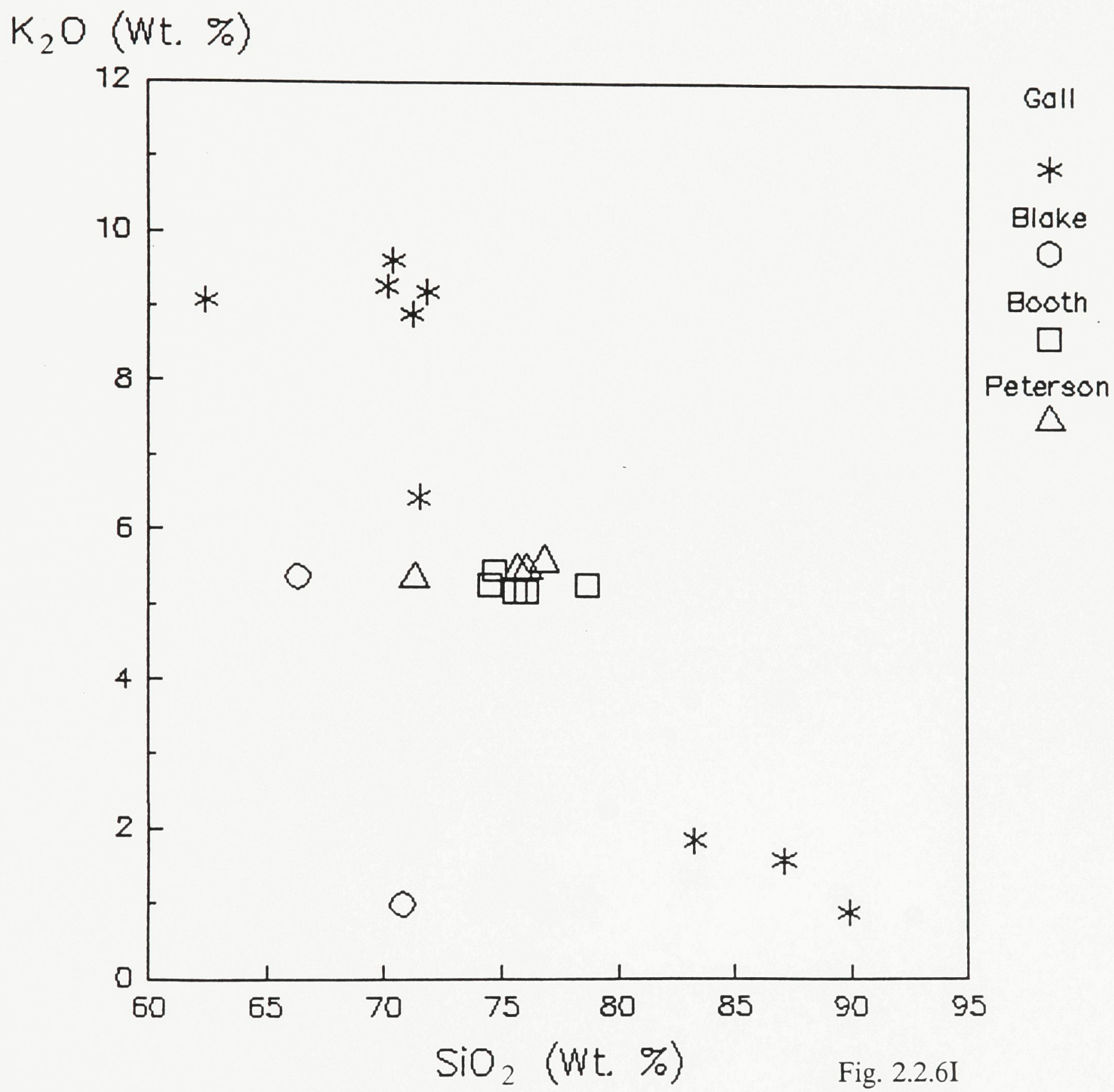




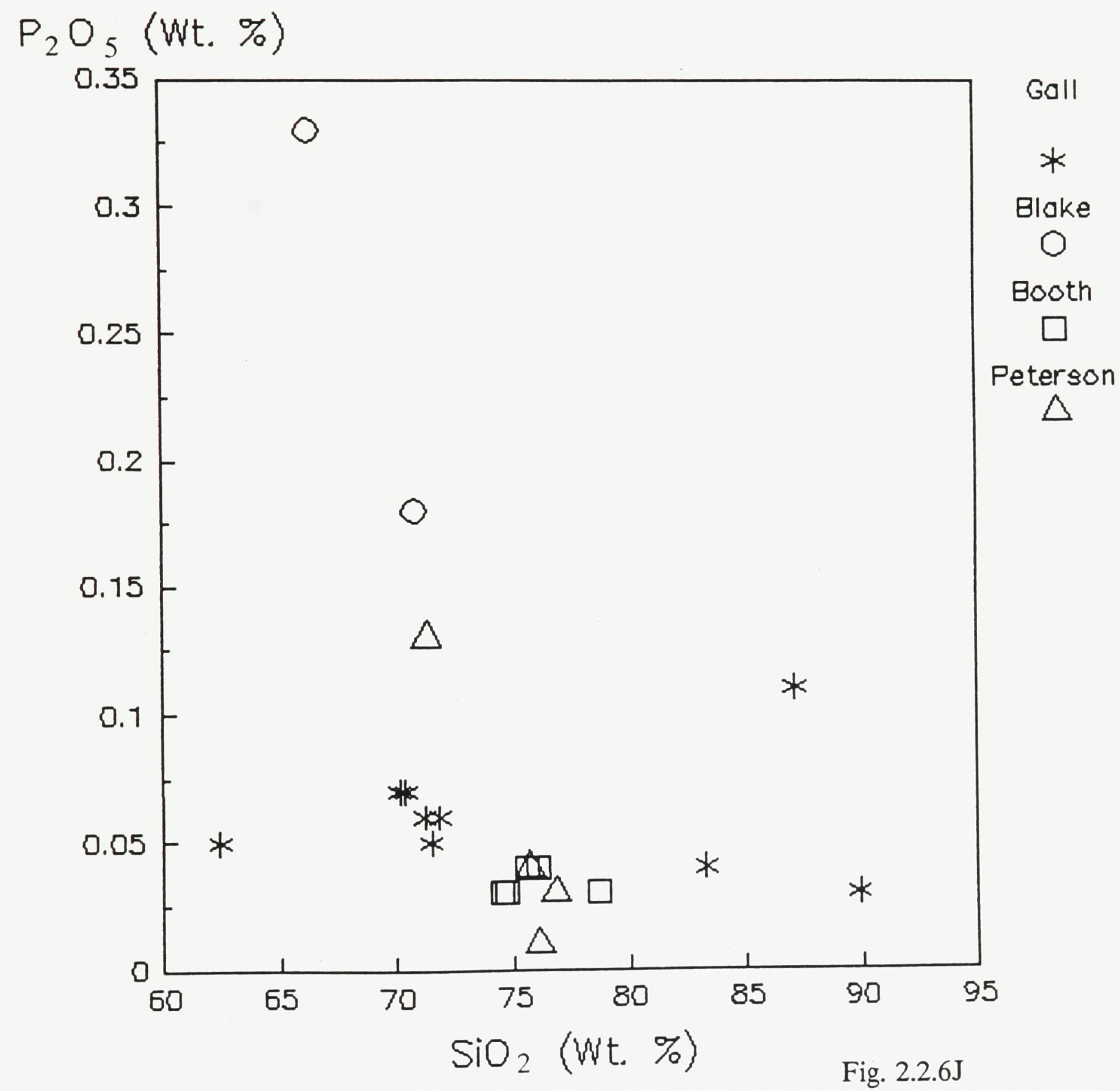


ClA

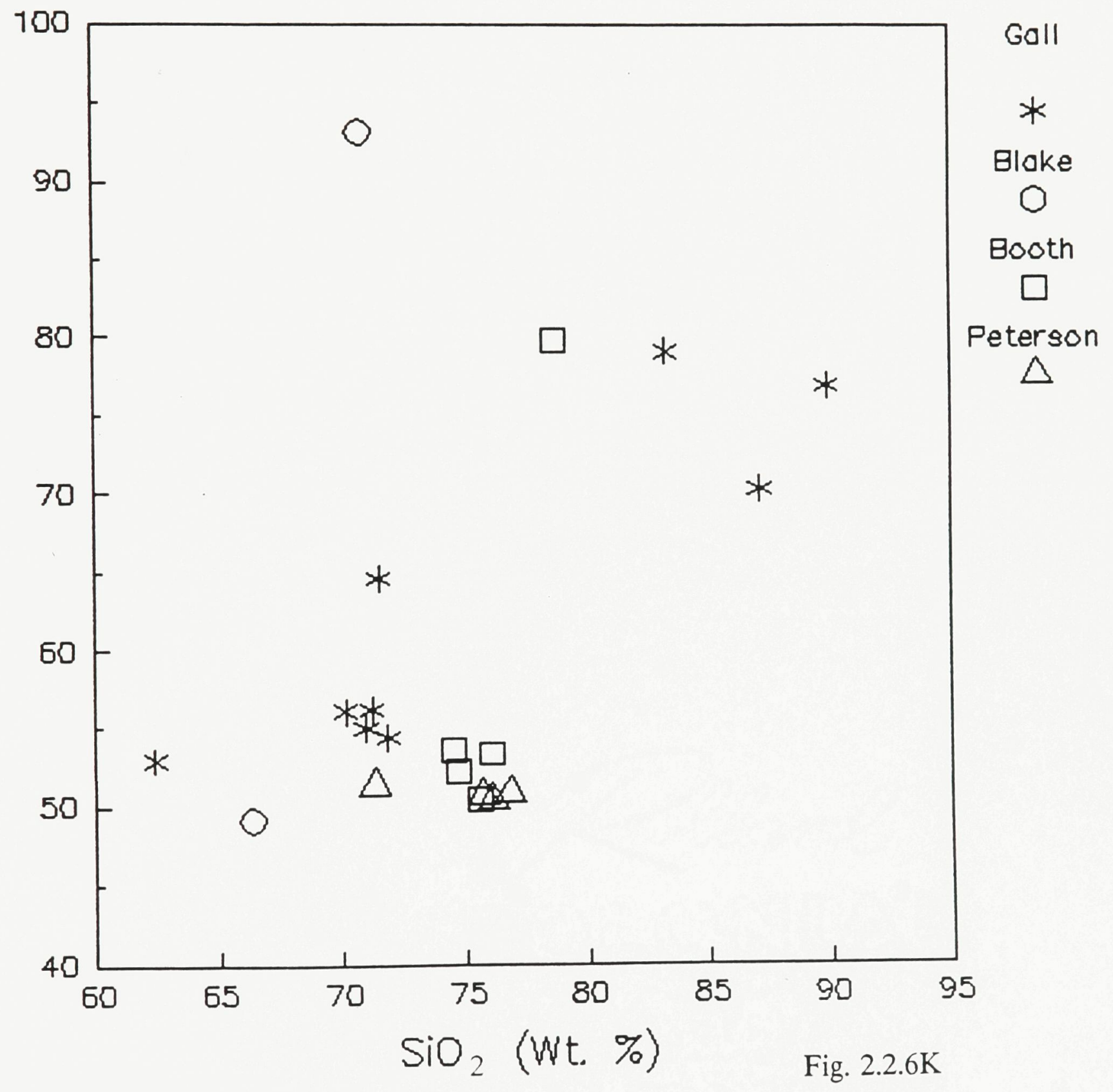




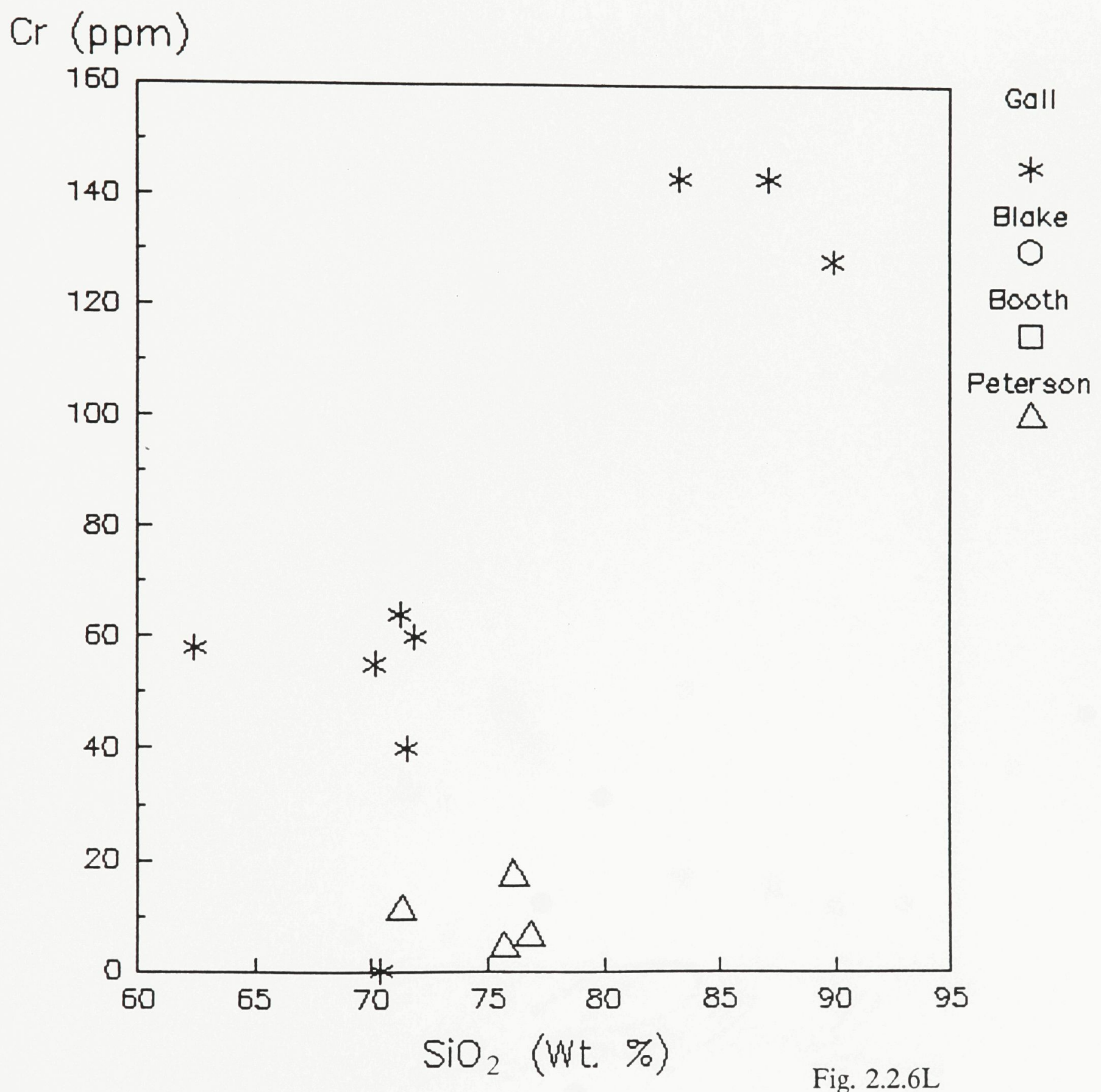

Fig. 2.2.6L 


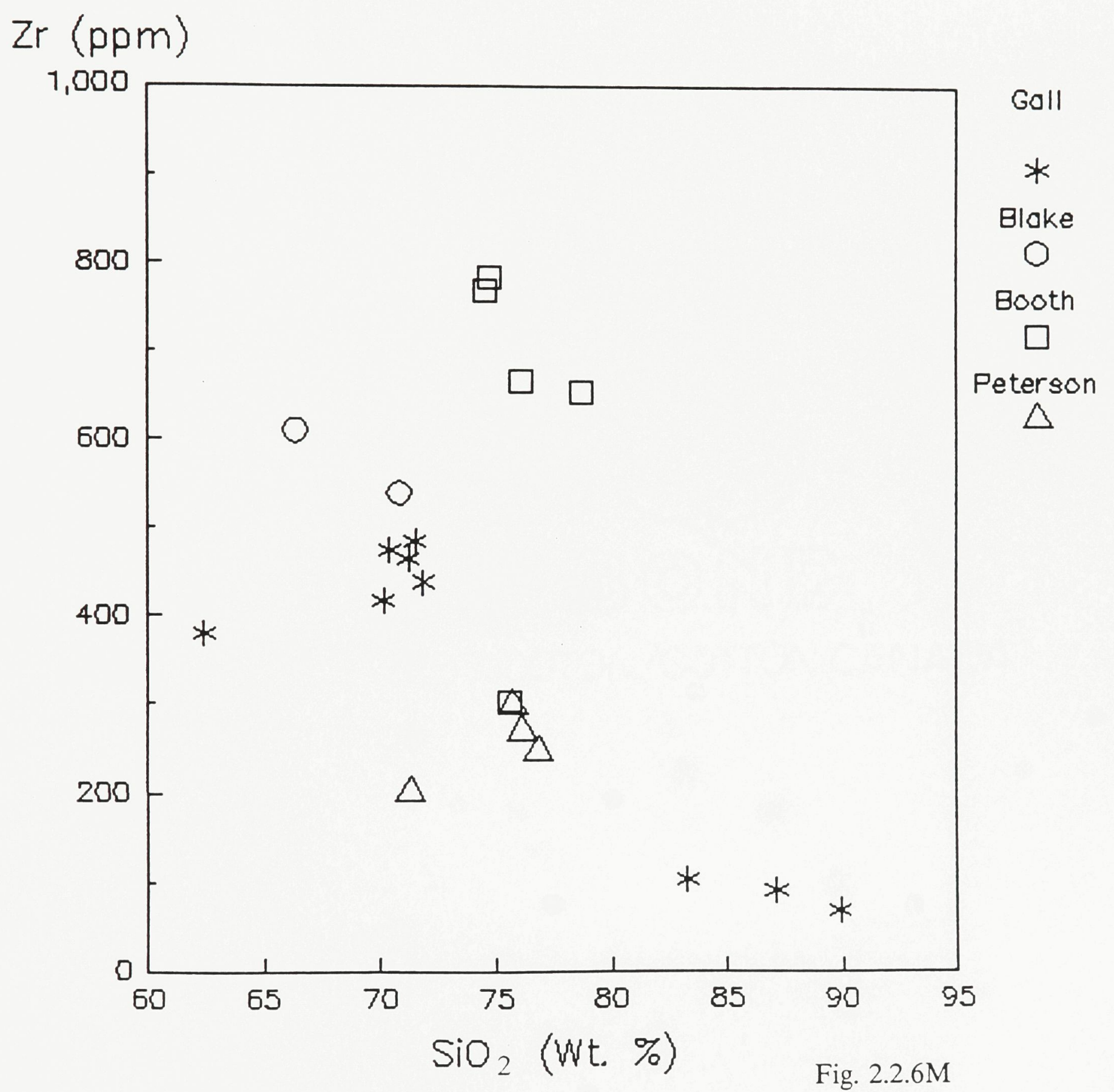




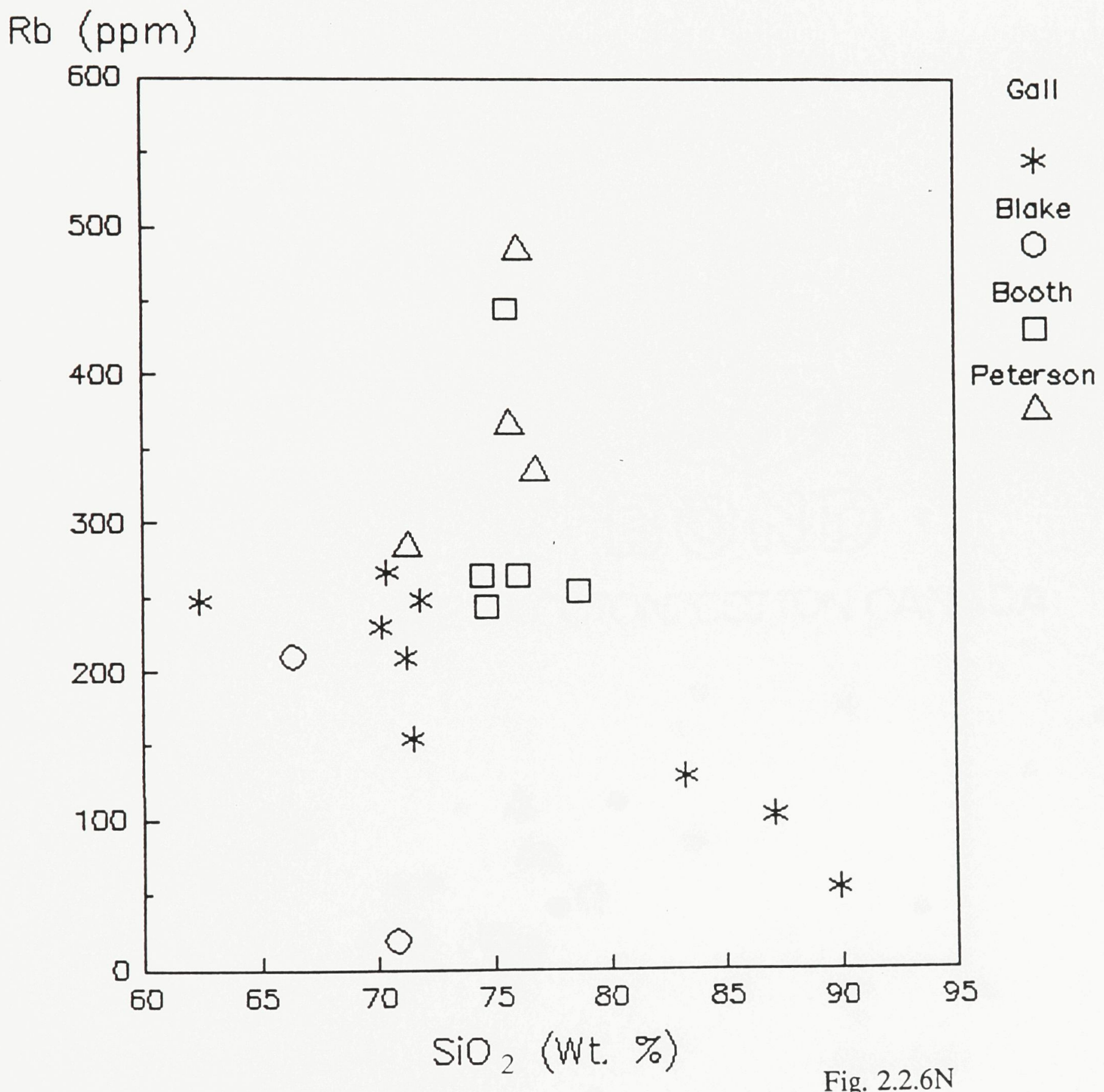




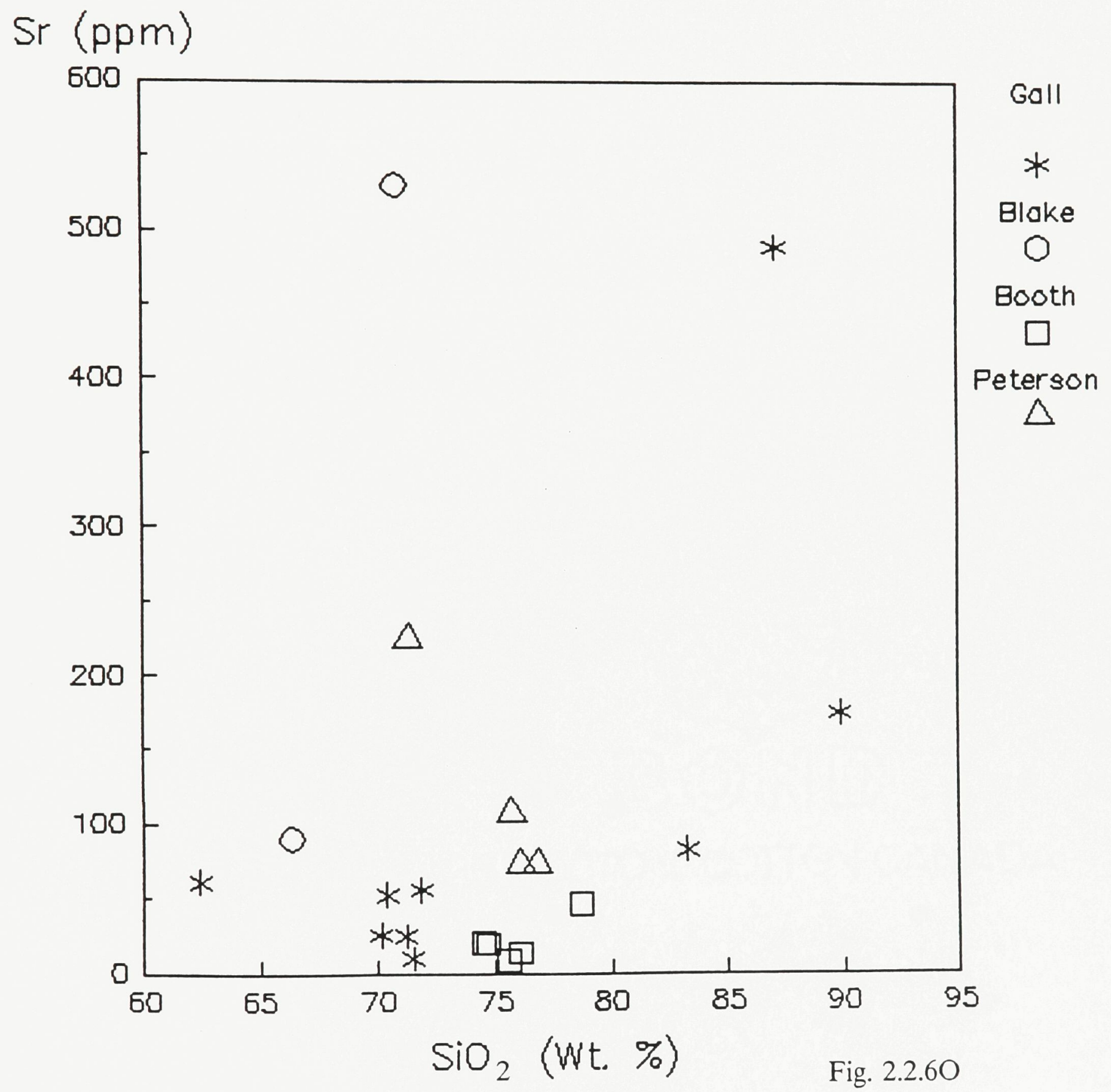




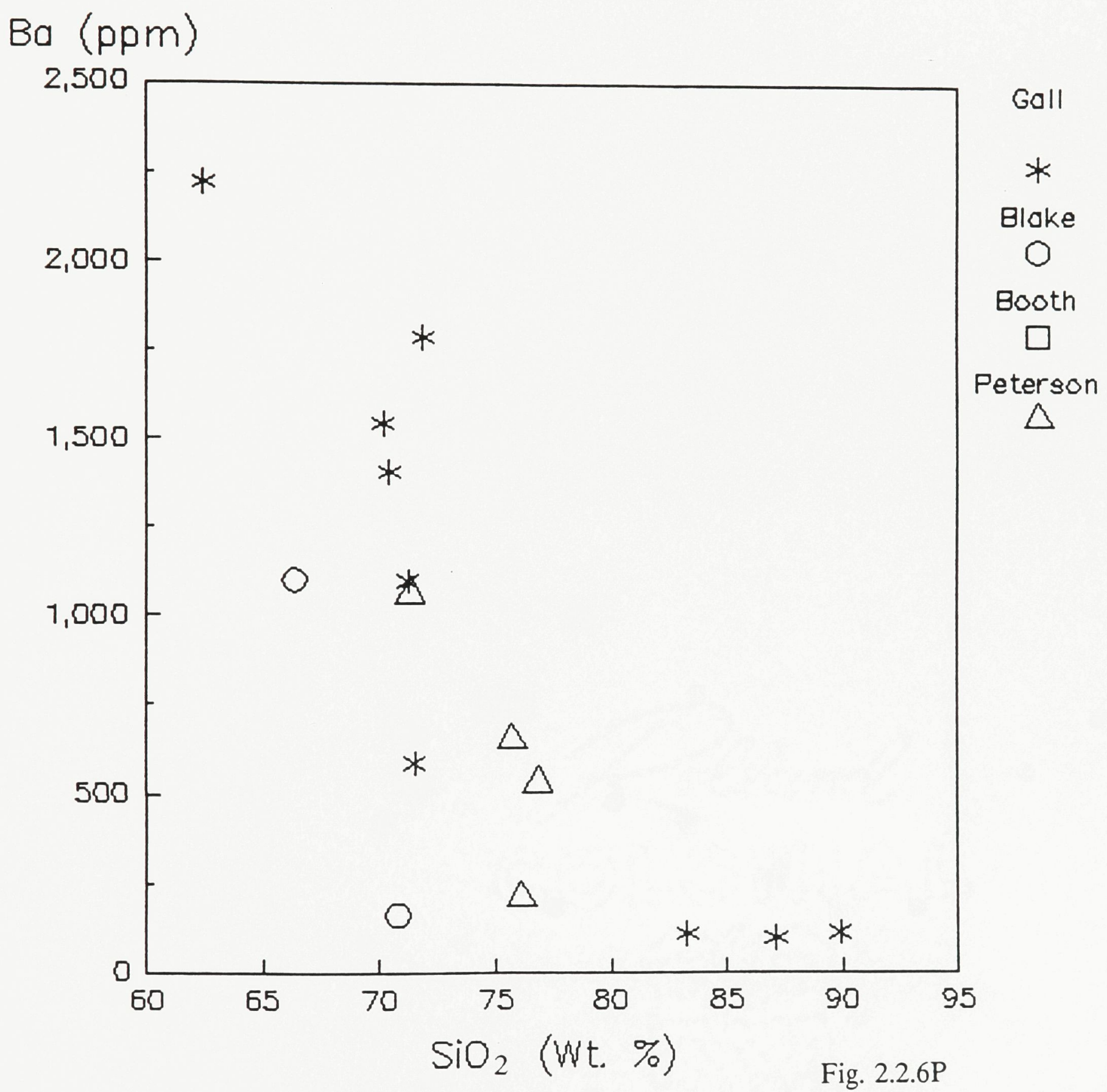




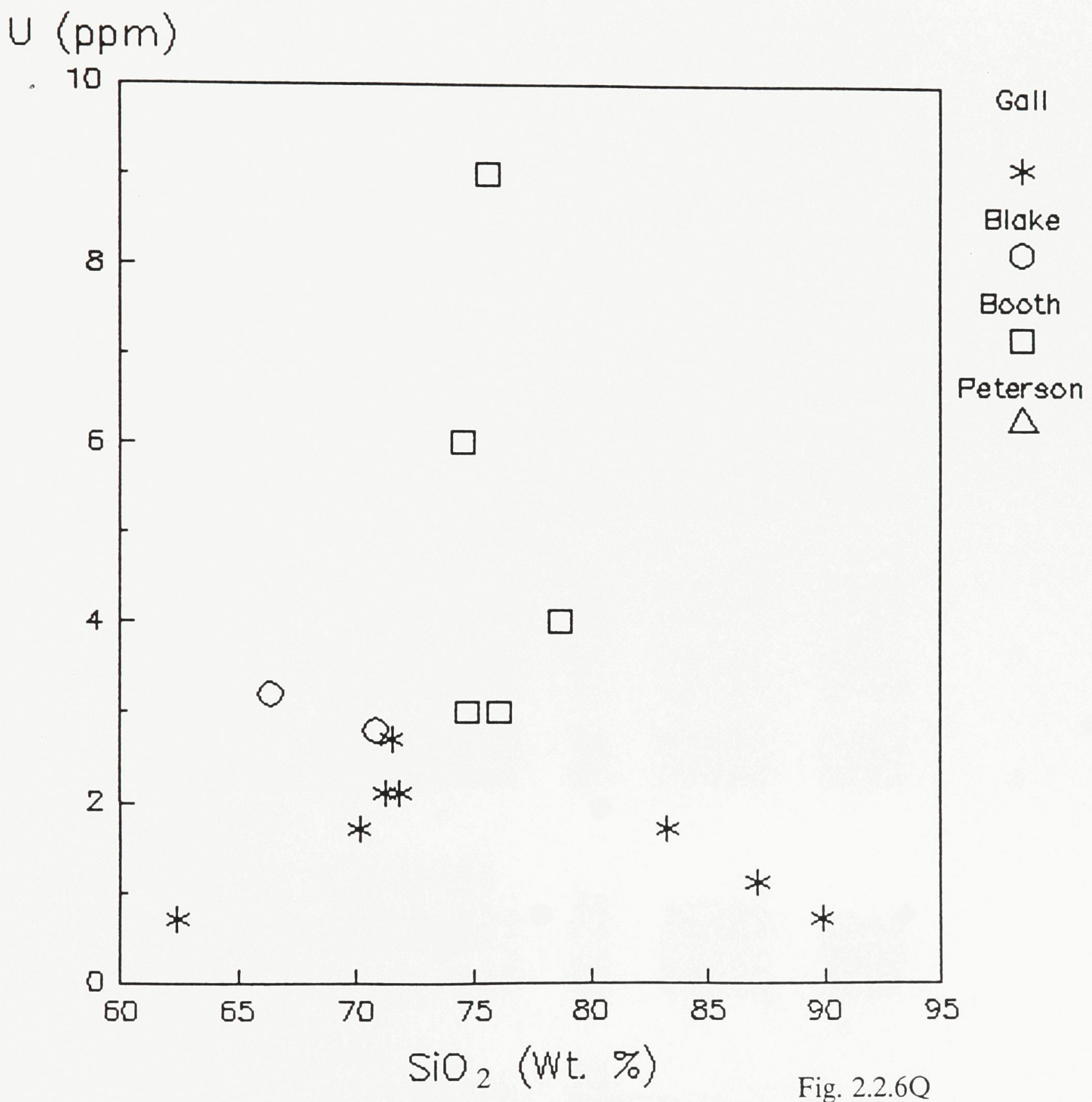




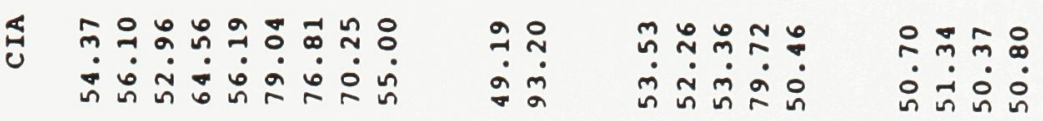

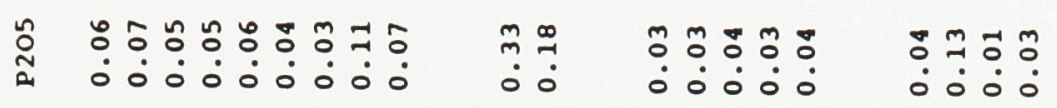

\

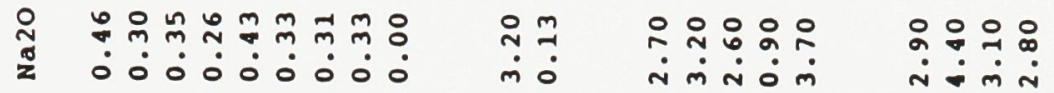

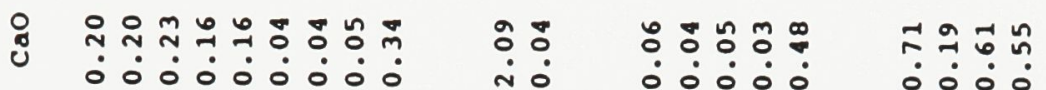

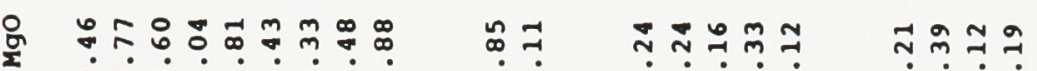

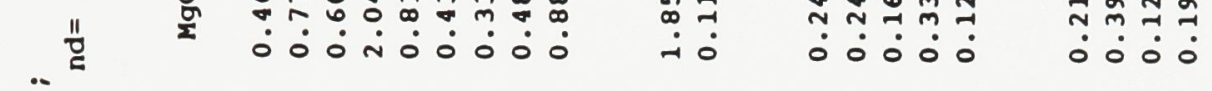

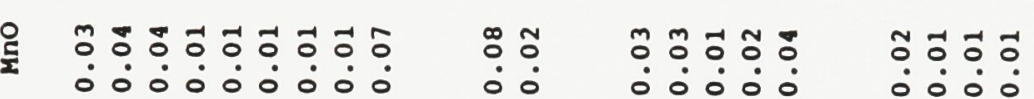

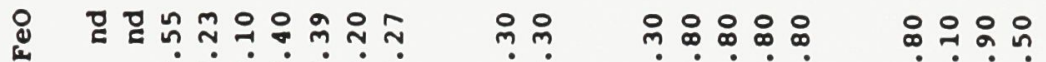

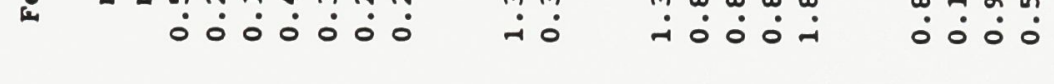

象

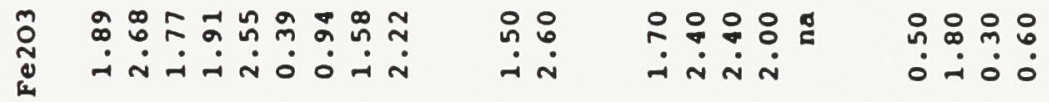

ํํำ

约

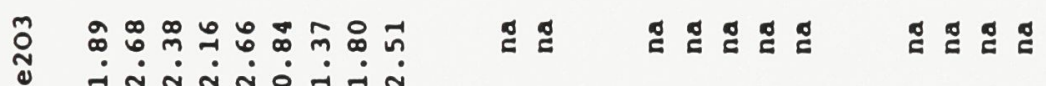

ᄃิ

论

若

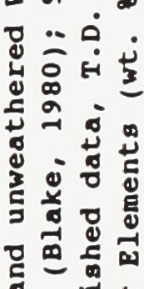

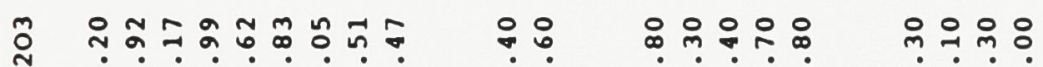

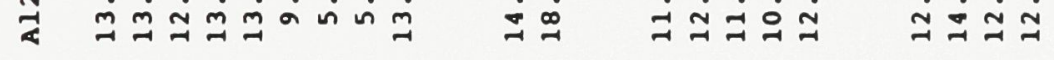

กิ 우ำ

:00000000 00 00:00 0000

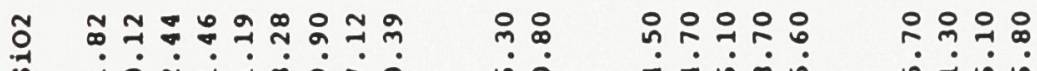

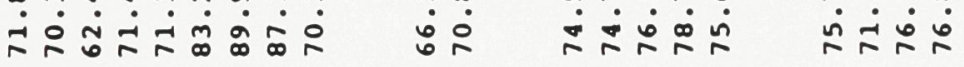

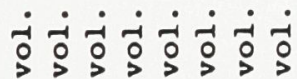

范

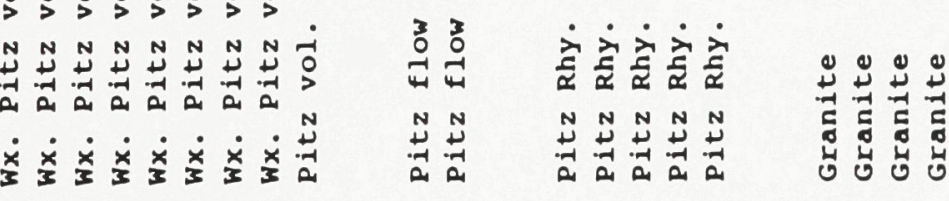


Table 2.2.1 (continued)

Trace Elements (ppm)

$$
2-2-32
$$

$\begin{array}{ll}\text { Sample\# } & \text { Lithology } \\ \text { QG-89-1 } & \text { Wx. Pitz vol. } \\ \text { QG-89-2 } & \text { Wx. Pitz vol. } \\ \text { QG-89-3 } & \text { Wx. Pitz vol. } \\ \text { QG-89-4 } & \text { Wx. Pitz vol. } \\ \text { QG-89-5 } & \text { Wx. Pitz vol. } \\ \text { QG-89-9 } & \text { Wx. Pitz vol. } \\ \text { QG-89-10 } & \text { Wx. Pitz vol. } \\ \text { QG-89-12 } & \text { Wx. Pitz vol. } \\ \text { QG-92-27 } & \text { Pitz vol. }\end{array}$

$\begin{array}{lllll}\mathrm{Cr} & \mathrm{Zr} & \mathrm{Rb} & \mathrm{Sr} & \mathrm{Ba}\end{array}$

$\begin{array}{rrrrrr}60 & 438 & 248 & 56 & 1786 & 2.1 \\ 55 & 417 & 230 & 26 & 1540 & 1.7 \\ 58 & 379 & 247 & 61 & 2220 & 0.7 \\ 40 & 485 & 154 & 10 & 584 & 2.7 \\ 64 & 464 & 209 & 25 & 1096 & 2.1 \\ 143 & 102 & 129 & 82 & 108 & 1.7 \\ 128 & 67 & 54 & 174 & 110 & 0.7 \\ 143 & 90 & 103 & 488 & 93 & 1.1 \\ 0 & 475 & 267 & 52 & 1406 & \mathrm{na}\end{array}$

76LAAD349-1 Pitz flow

$\begin{array}{rrrrrr}\text { na } & 610 & 210 & 90 & 1100 & 3.2 \\ \text { na } & 540 & 20 & 530 & 160 & 2.8\end{array}$

$\begin{array}{ll}9 G 330-2 & \text { Pitz Rhy. } \\ 9 G 330-3 & \text { Pitz Rhy. } \\ 9 G 331-2 & \text { Pitz Rhy. } \\ 9 G 332-2 & \text { Pitz Rhy. } \\ \text { 9P25-2 } & \text { Pitz Rhy. }\end{array}$

$\begin{array}{llllll}\text { na } & 768.6 & 264.8 & 20.0 & \text { na } & 6 \\ \text { na } & 783.6 & 244.4 & 19.7 & \text { na } & 3 \\ \text { na } & 665.7 & 264.5 & 13.5 & \text { na } & 3 \\ \text { na } & 652.9 & 254.1 & 45.6 & \text { na } & 4 \\ \text { na } & 302.2 & 445.4 & 8.0 & \text { na } & 9\end{array}$

$\begin{array}{ll}\text { P89/23 } & \text { Granite } \\ \text { P89/303 } & \text { Granite } \\ \text { P88/500E } & \text { Granite } \\ \text { P88/500G } & \text { Granite }\end{array}$

$\begin{array}{rrrrrr}4 & 297 & 366 & 107 & 651 & \text { na } \\ 11 & 201 & 283 & 223 & 1058 & \text { na } \\ 17 & 269 & 484 & 72 & 206 & \text { na } \\ 6 & 245 & 334 & 72 & 529 & \text { na }\end{array}$


CHAPTER TWO

SECTION THREE

BEHAVIOUR OF RARE EARTH ELEMENTS IN THE THELON PALEOSOL. 


\section{INTRODUCTION}

A literature review of geochemically analyzed pre-Quaternary paleosols reveals that few have been analyzed for their rare earth element (REE) content. When only Paleozoic or Precambrian paleosols are considered, fewer than ten studies which include REE analyses are known to the author, and of these, only two deal with Precambrian paleosols in Canada. Schau and Henderson (1983) reported that heavy REE (HREE) are depleted in paleoweathered Archean granodiorite near Steep Rock, whereas Kimberley and Grandstaff (1986) reported an unfractionated REE distribution in the paleoweathered Archean Kinojevis basalt near Kirkland Lake.

This study was undertaken to determine the behaviour of REE in the Thelon paleosol, thereby further testing the extent of REE mobility and fractionation during Precambrian weathering. To this end, samples from Profiles 1,2 and 4, for which major oxide and other trace element contents have been determined (Section One), were analyzed for the following rare earth elements: La, Ce, Nd, Sm, Eu, Gd, Dy, Er, Yb and Lu. Profile 3 was not analyzed for its REE content due to fiscal and time constraints. REE were analyzed using ICP-AES (sample preparation and instrumentation for REE ICP-AES analyses are outlined in Appendix I). The rare earth elements $\operatorname{Pr}, \mathrm{Tb}, \mathrm{Ho}$ and $\mathrm{Tm}$ were not analyzed due to their interference with secondary energy peaks of other elements, which creates poor spectrum peak resolution for quantification. As in Section One, concentration ratios (Gay and 
Grandstaff, 1980) are used to gauge element behaviour within each profile. In order to detect element trends for the three profiles, $\mathrm{Al}_{2} \mathrm{O}_{3}$ was assumed to be a stable component, to which fluctuations in the abundance of other elements could be compared.

Evidence for REE mobility and fractionation in the Thelon paleosol was also sought by normalizing the data to standard chondrite REE values. The resulting chondrite-normalized graphs not only show the relative amounts of REE in the samples, but also reveal any systematic light- to heavy-REE variations which may exist between samples. The average $\mathrm{C} 1$ chondrite values used in the calculations are those determined by Evensen et al. (1978).

\section{RESULTS}

Profile 1

Based on physical features and major oxide and trace element trends defined in Section One, Profile 1 consists of three samples of basal 'fresh' hornblende- and biotite-bearing granitoid augen gneiss, successively overlain by five paleosol samples and one basal Thelon Formation sample. The REE contents of each of the nine samples are shown in Table 2.3.1. Concentration ratios for each of the rare earth elements were calculated and plotted in Figs. 2.3.1A to 2.3.1E. Inspection of Figs. 2.3.1A to 2.3.1E suggest that the following trends exist within the Thelon paleosol, 
compared to 'fresh' protolith: an increase in La, and a decrease in Sm, Eu, Gd, Yb and Lu. A more subtle decrease in $\mathrm{Nd}$, Dy and Er also occurs within the paleosol samples.

Chondrite normalization of the REE analyses (Fig. 2.3.2) shows that the unweathered protolith samples $(171-14,-16,-18)$ have $\mathrm{La}$, Ce and $\mathrm{Nd}$ values similar to the paleosol values, but the other REE show a depletion compared to the unweathered samples. All samples display the same relative light REE (LREE, La to Eu) enrichment compared to the HREE ( $\mathrm{Gd}$ to $\mathrm{Lu}$ ), as well as a negative Eu anomaly, although the paleosol samples show a greater negative Eu anomaly than the unweathered samples. These trends indicate REE mobility (depletion) in the paleosol, especially Eu, but no fractionation between LREE and HREE that may be attributed to paleoweathering.

Profile 2

Profile 2 has developed on a megacrystic microcline granite. It consists of two 'fresh' granite protolith samples, successively overlain by two paleosol samples and three Thelon Formation samples. The REE content of the seven Profile 2 samples are shown in Table 2.3.1. Concentration ratios, calculated from the REE analyses, have been plotted in Figs. 2.3.3A to 2.3.3E. A few weak trends are evident from inspection of these plots. These trends within the paleosol samples are, compared to the unweathered granite protolith, a slight increase in $\mathrm{Gd}$ and $\mathrm{Lu}$, and a slight 
decrease in Dy.

Chondrite normalization of the REE analyses for Profile 2 samples (Fig. 2.3.4) shows that, except for an increase in $\mathrm{Gd}$, the paleosol samples $(88-4,-5)$ have REE values similar to the unweathered protolith samples. As well, the paleosol and unweathered samples show similar LREE enrichment compared to the HREE, suggesting that paleoweathering did not result in fractionation between LREE and HREE.

Profile 4

In Profile 4, the Thelon paleosol is developed on a fine-grained semipelitic schist. Unlike samples from Profiles 1 and 2 which are from outcrop, Profile 4 samples are from core recovered from drill hole QB-2. Based on physical features and major oxide and trace element trends (Section One), the five deepest samples are considered to be relatively unweathered protolith, the overlying four samples are considered paleosol, and the two shallowest samples are Thelon Formation sandstone. The REE content of the eleven profile samples is shown in Table 2.3.1. Plots of concentration ratios against profile depth are shown in Figs. 2.3.5A to 2.3.5E. Compared to the unweathered protolith samples, the Profile 4 concentration ratio trends for all REE show at least a weak REE increase within the paleosol samples. This is in contrast to a depletion of many of the same elements within the paleosol in Profile 1. 
Profile 4 chondrite normalized REE values (Fig. 2.3.6) confirm the trends displayed by the concentration ratio plots, in that four relatively unweathered samples $(-490,-466,-412,-369)$ have less REE than the overlying four paleosol samples. Nd, Gd and Lu in particular show elevated abundance in the paleosol compared to the unweathered protolith. The general REE pattern of elevated LREE abundance compared to the HREE persists for both the paleosol and unweathered protolith, suggesting that fractionation between LREE and HREE did not occur during paleoweathering.

\section{DISCUSSION}

Some studies of fine-grained sedimentary successions have revealed variations in REE content, suggesting that REE have been mobilized and fractionated to varying degrees during chemical weathering of the source area, especially during periods of humidity (e.g., Balashov et al., 1964; Ronov et al., 1967; Roaldset, 1973). Other studies of particular weathering profiles (e.g., Nesbitt, 1979; Duddy, 1980; Topp et al., 1984; Middleburg et al., 1988; Braun et al., 1990) have demonstrated that REE are mobilized and fractionated during weathering, commonly resulting in a LREE-enriched residuum and a HREE-enriched illuvium.

The variations in REE concentration ratios within the three Thelon paleosol profiles, particularly Profiles 1 and 4, as compared to the unweathered protoliths, also suggest, as with previous studies, that paleoweathering has resulted in REE 
mobility. However, there is a contradiction in the REE concentration ratio profiles, in that $\mathrm{Nd}, \mathrm{Sm}, \mathrm{Eu}, \mathrm{Gd}, \mathrm{Dy}, \mathrm{Yb}$ and Lu show an apparent depletion within the Thelon paleosol in Profile 1, but the same elements are enriched within the Thelon paleosol in Profile 4, compared to the unweathered metamorphic protoliths.

The depletion of many REE within the paleosol in Profile 1 mimics the depletion of many major oxides and trace elements, as demonstrated in Section One of this chapter. This depletion ultimately reflects the upward increase in alteration of feldspar, biotite and hornblende in Profile 1. High positive correlation coefficients between REE and major oxides for Profile 1 samples (Table 2.3.2), support the association between increased REE depletion and increased weathering of labile REE-bearing minerals.

The converse is true for Profile 4. That is, accompanying the upward increase in protolith weathering (increased feldspar and mica alteration), as demonstrated in Section One, there is an increase in REE concentration. Although many of the REE concentration ratio plots for Profile 4 (Figs. 2.3.5A to 2.3.5E) do not demonstrate a large increase in each rare earth element, they all show a positive slope within the paleosol. Two possible explanations for the apparent increase in REE towards the top of the paleosol are as follows:

(1) The unconformity intersected a paleoweathering zone of relative REE accumulation. This seems unlikely however, because no accumulation (illuviation) 
zones have been identified, and, REE fractionation is commonly associated with such illuvial zones (Nesbitt, 1979; Duddy, 1980; Topp et al., 1984), although there is no evidence of REE fractionation in Profile 4.

(2) Because the REE-bearing APS mineral has overprinted the Thelon paleosol during diagenesis of the overlying Thelon Formation (Chapter 3, Section One), and has specifically been identified in Profile 4 paleosol and Thelon Formation samples, the increase in REE towards the unconformity may simply reflect the presence of diagenetic REE-bearing APS crystals in the paleosol. This second option is the most plausible explanation to date.

Normalizing the REE analyses to average $\mathrm{C} 1$ chondrite reinforces the trends detected using concentration ratios. The chondrite-normalized plots show that, relative to unweathered protolith, there is a decrease in many REE within the paleosol in Profile 1, and an increase in most REE within the paleosol in Profile 4. The chondrite-normalized plots also give an indication of whether fractionation took place during weathering and led to relative depletion or enrichment between the REE. The general trend of decreasing abundance of REE with increasing atomic number is consistent for the unweathered protolith samples and the Thelon paleosol samples in all three profiles. This suggests that LREE and HREE have not behaved differently during weathering. Furthermore, correlation coefficients between all analyzed elements for protolith and paleosol samples in Profile 1 (Table 2.3.2), Profile 2 (Table 2.3.3) and Profile 4 (Table 2.3.4), show that many REE have strong 
positive correlations with other REE, including between LREE and HREE. The strong positive correlation between many LREE and HREE in the profiles is taken as further evidence that these two groups of REE did not fractionate with respect to one another during weathering.

\section{OBSERVATIONS AND CONCLUSIONS}

Analyses of rare earth elements in samples from three Thelon paleosol profiles, and the normalization of these analyses to the $\mathrm{Al}_{2} \mathrm{O}_{3}$ content of the samples and to average $\mathrm{C} 1$ chondrite, has resulted in the following:

(1) Many REE in Profiles 1, and some REE in Profile 2, show a depletion in the paleosol compared to the unweathered protolith. This is attributed to their mobility and eluviation during formation of the Thelon paleosol.

(2) The increase in REE within the paleosol in Profile 4 is attributable, at least in part, to diagenetic overprinting of the paleosol by a REE-bearing APS mineral.

(3) Generally, there is no indication of fractionation between the LREE and HREE due to weathering.

\section{REFERENCES}

Balashov, Yu.A., Ronov, A.B., Migdisov, A.A. and Turanskaya, N.V. 1964. The effects of climate and facies environment in the fractionation of the rare earths during sedimentation. Geochemistry International, v. 10, pp. 951-969. 
Braun, J.-J., Pagel, M., Muller, J.-P., Bilong, P., Michard, A. and Guillet, B. 1990. Cerium anomalies in lateritic profiles. Geochimica Cosmochimica Acta, v. 54, pp. 781-795.

Duddy, I.A. 1980. Redistribution and fractionation of rare-earth and other elements in a weathering profile. Chemical Geology, v. 30, pp. 363-381.

Evensen, N.M., Hamilton,, P.J. and O'Nions, R.K. 1978. Rare-earth abundances in chondritic meteorites. Geochimica Cosmochimica Acta, v. 42, pp. 1199-1212.

Gay, A. and Grandstaff, D.E. 1980. Chemistry and mineralogy of Precambrian paleosols at Elliot Lake, Ontario. Precambrian Research, v. 12, pp. 349-373.

Kimberley, M.M. and Grandstaff, D.E. 1986. Profiles of elemental concentrations in Precambrian paleosols on basaltic and granitic parent material. Precambrian Research, v. 32, pp. 229-233.

Middelburg, J.J., Van Der Weijden, C.H. and Woittiez, J.R.W. 1988. Chemical processes affecting the mobility of major, minor and trace elements during weathering of granitic rocks. Chemical Geology, v. 68, pp. 253-273.

Nesbitt, H.W. 1979. Mobility and fractionation of rare earth elements during 
weathering of a granodiorite. Nature, v. 279, pp. 206-210.

Roaldset, E. 1973. Rare earth elements in the Quaternary clays of the Numedal area, southern Norway. Lithos, v. 6, pp. 349-372.

Ronov, A.B., Balashov, Yu.A., and Migdisov, A.A. 1967. Geochemistry of the rare earths in the sedimentary cycle. Geochemistry International, v. 4, pp. 1-17.

Schau, M. and Henderson, J.R. 1983. Archean chemical weathering at three localities on the Canadian Shield. Precambrian Research, v. 20, pp. 189-224.

Topp, S.E., Salbu, B., Roaldset, E. and Jorgensen, P. 1984. Vertical distribution of trace elements in laterite soil (Suriname). Chemical Geology, v. 47, pp. 159-174. 


\section{FIGURE CAPTIONS}

Figure 2.3.1. Concentration ratio distributions for rare earth elements within Profile 1 protolith, paleosol and Thelon Formation samples. (A) La, Ce, (B) Nd, Sm, (C) Eu, Gd, (D) Dy, Er, (E) Yb, Lu.

Figure 2.3.2. Comparison of REE patterns for Profile 1 samples. Data plotted relative to chondritic (C1) average REE values (Evanson et al., 1978).

Figure 2.3.3. Concentration ratio distributions for rare earth elements within Profile 2 protolith, paleosol and Thelon Formation samples. (A) La, Ce, (B) Nd, Sm, (C) Eu, Gd, (D) Dy, Er, (E) Yb, Lu.

Figure 2.3.4. Comparison of REE patterns for Profile 2 samples. Data plotted relative to chondritic (C1) average REE values (Evanson et al., 1978).

Figure 2.3.5. Concentration ratio distributions for rare earth elements within Profile 4 protolith, paleosol and Thelon Formation samples. (A) La, Ce, (B) Nd, Sm, (C) Eu, Gd, (D) Dy, Er, (E) Yb, Lu.

Figure 2.3.6. Comparison of REE patterns for Profile 4 samples. Data plotted relative to chondritic (C1) average REE values (Evanson et al., 1978). 


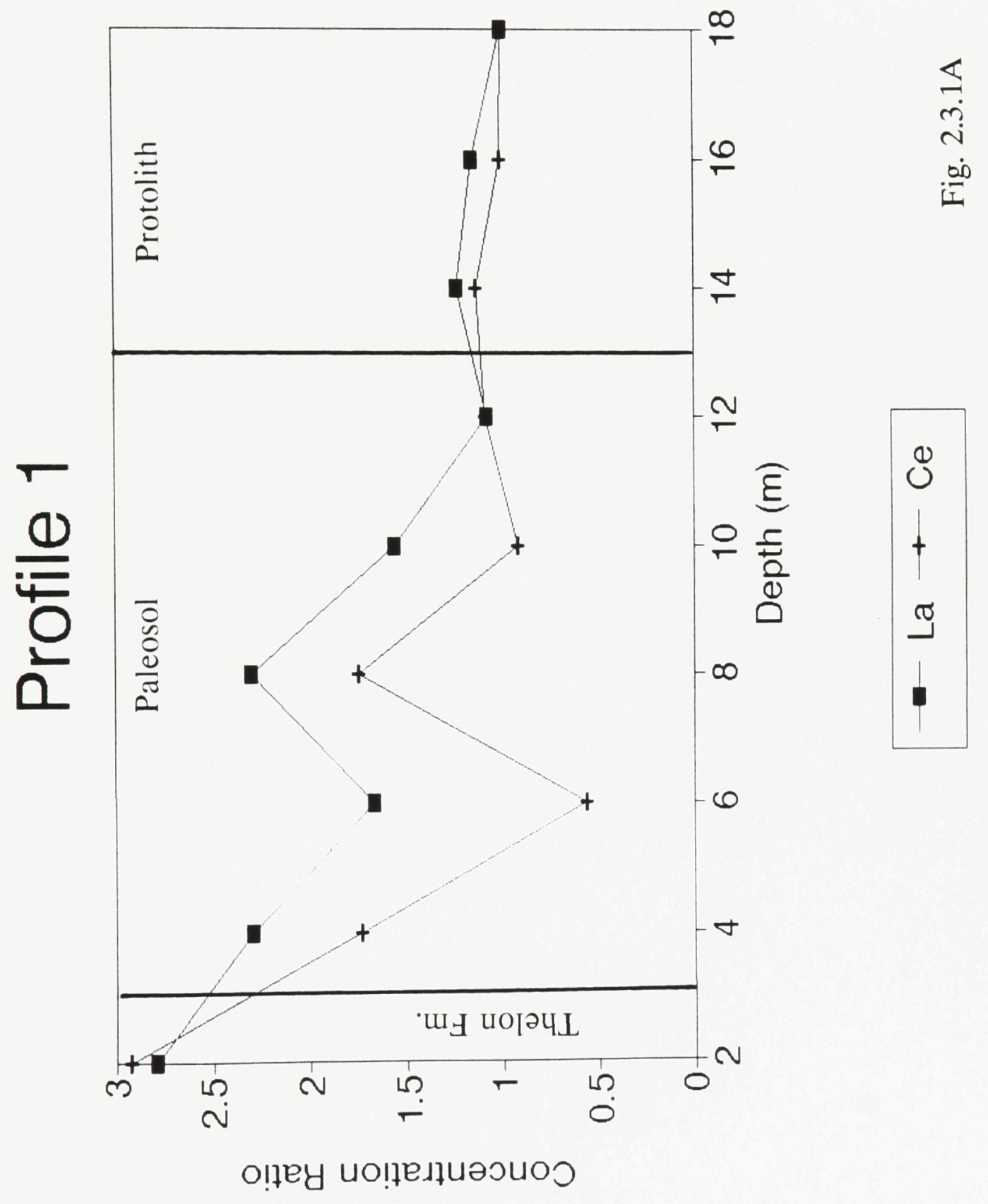




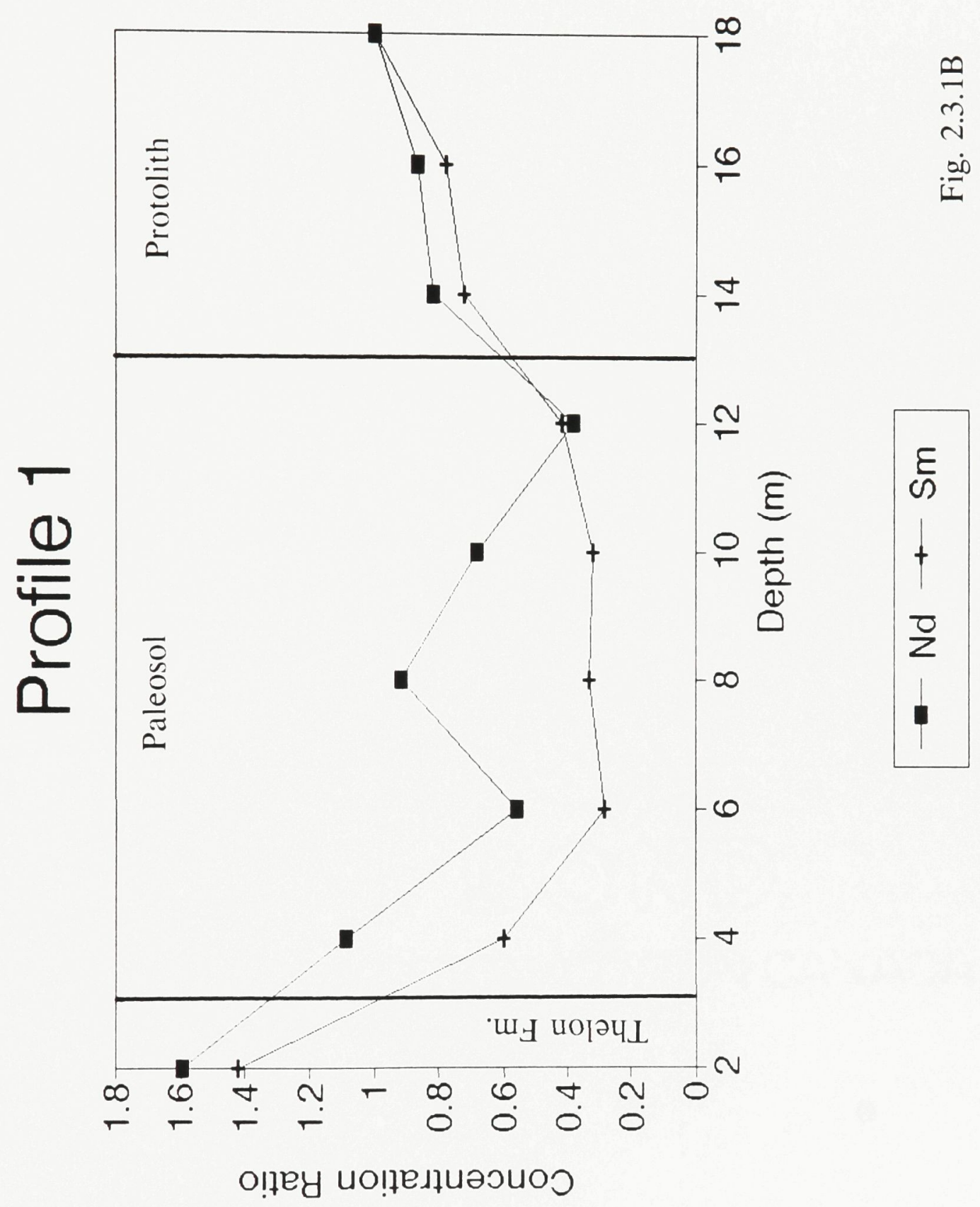




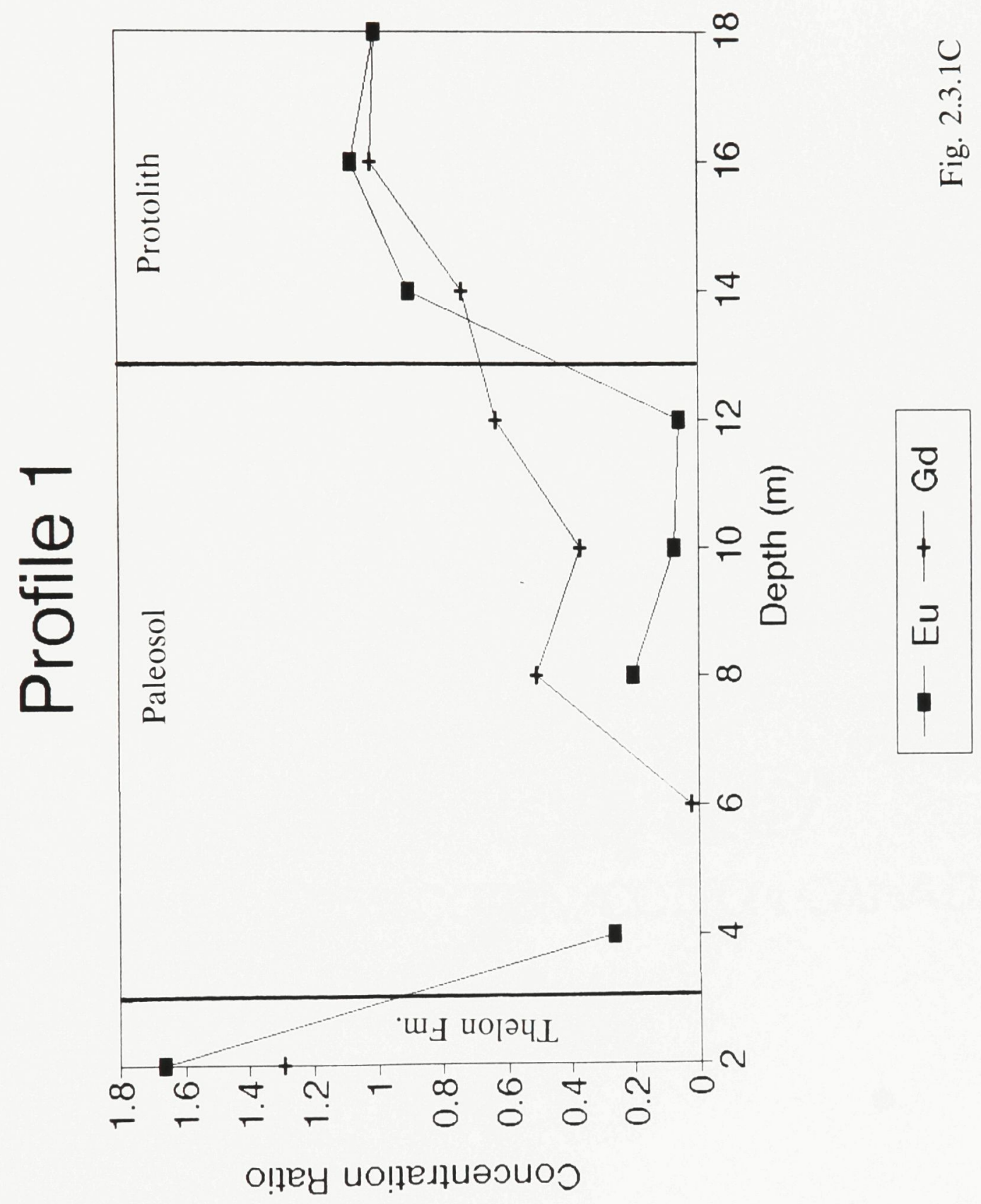




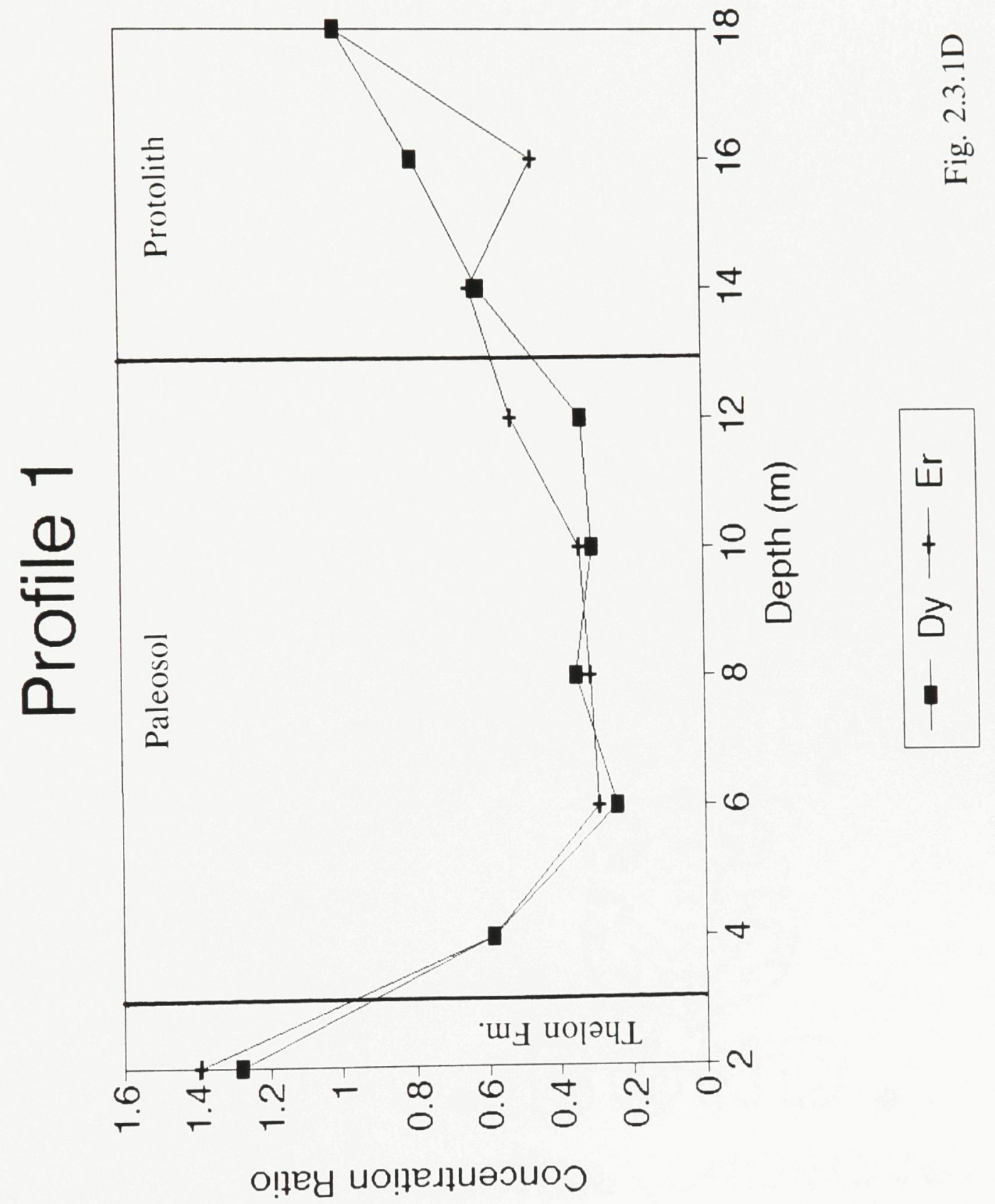




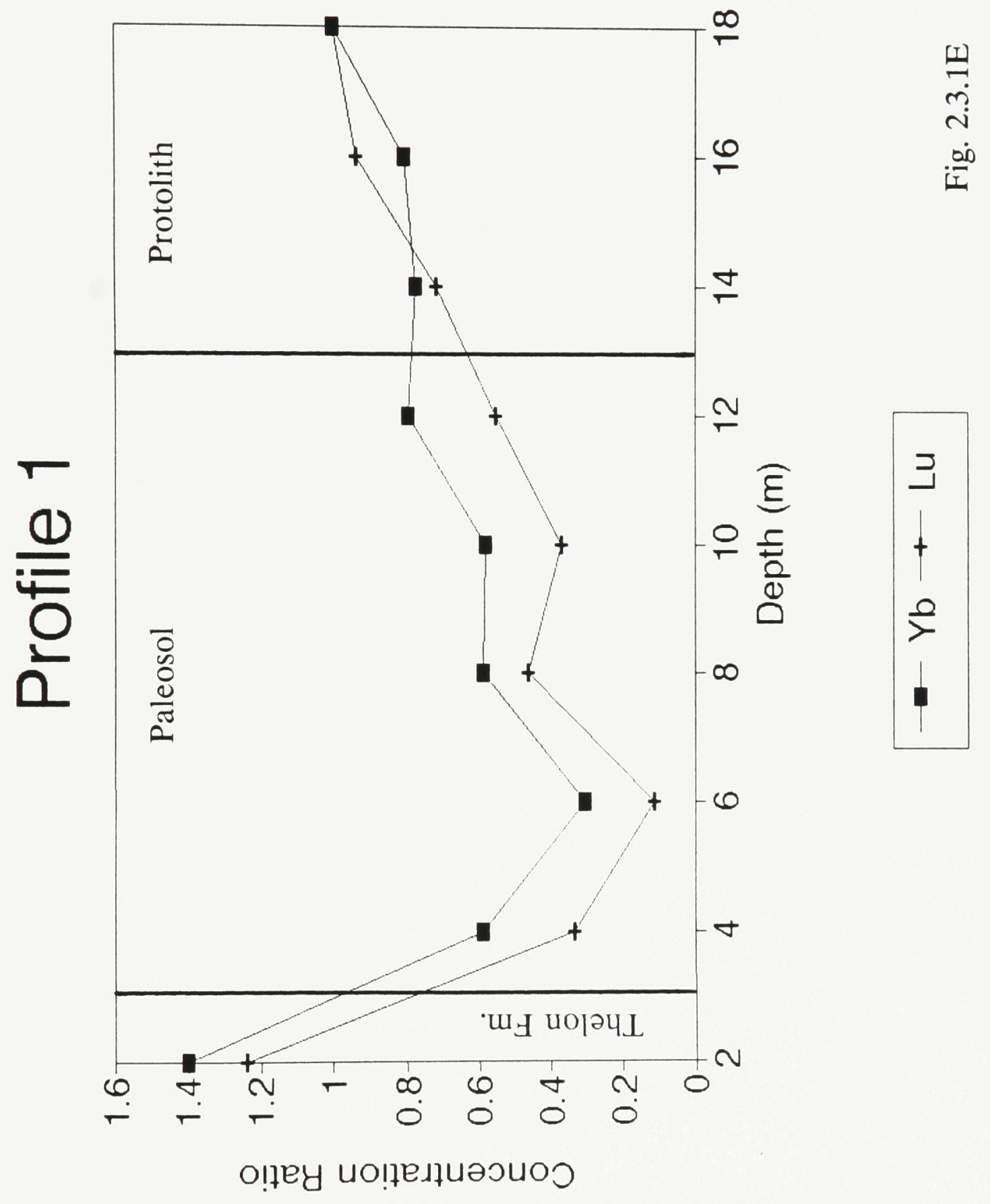




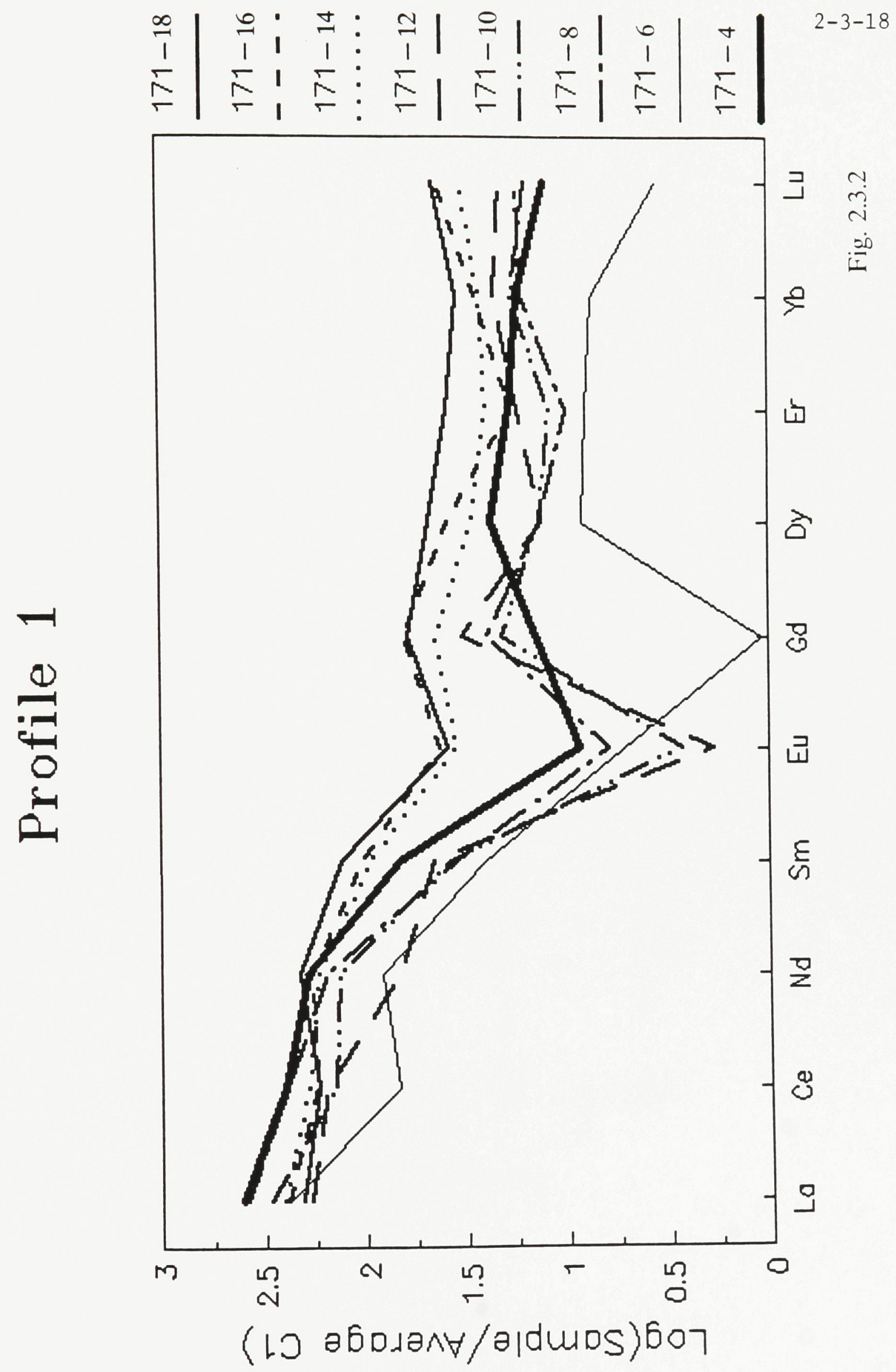




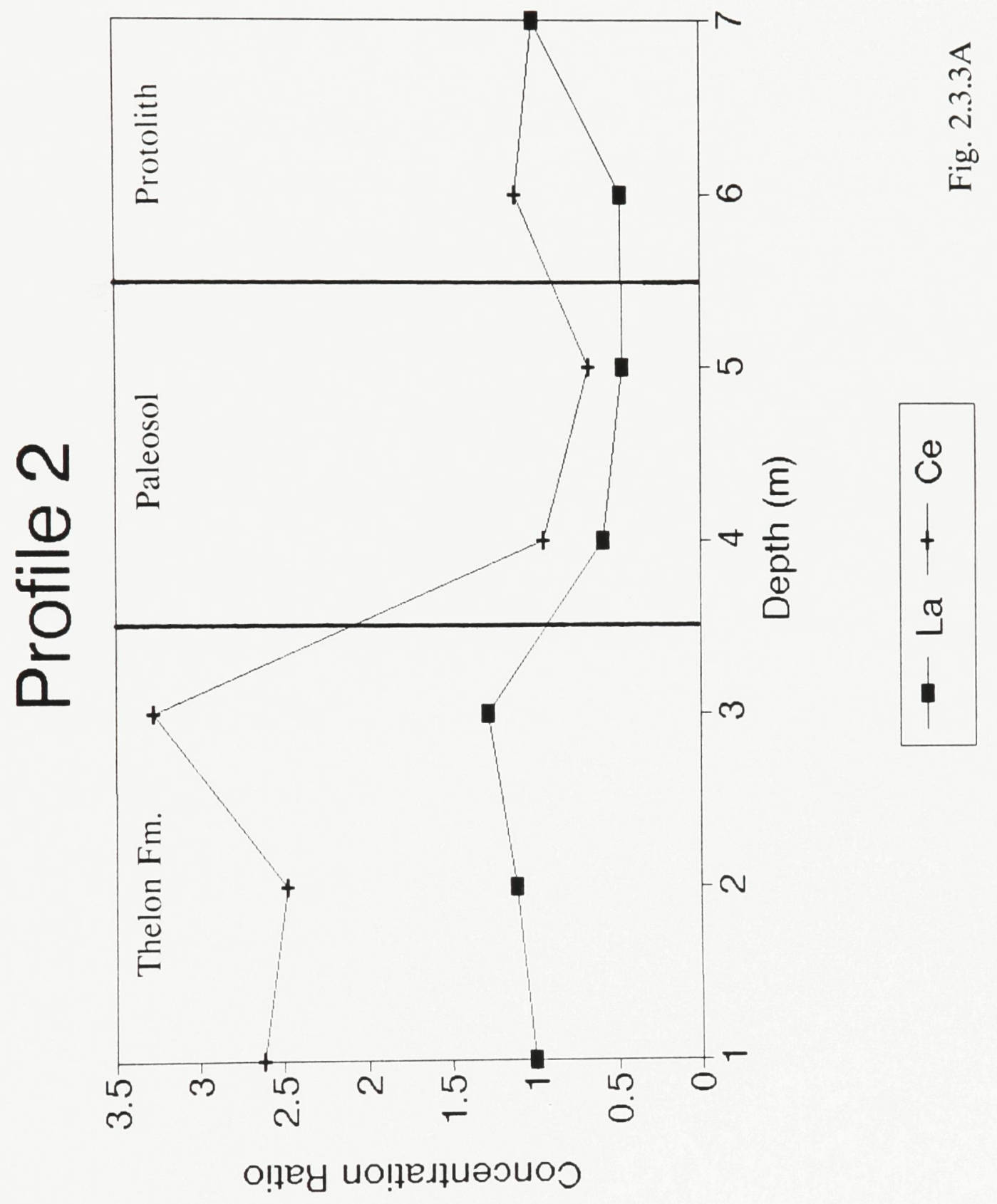




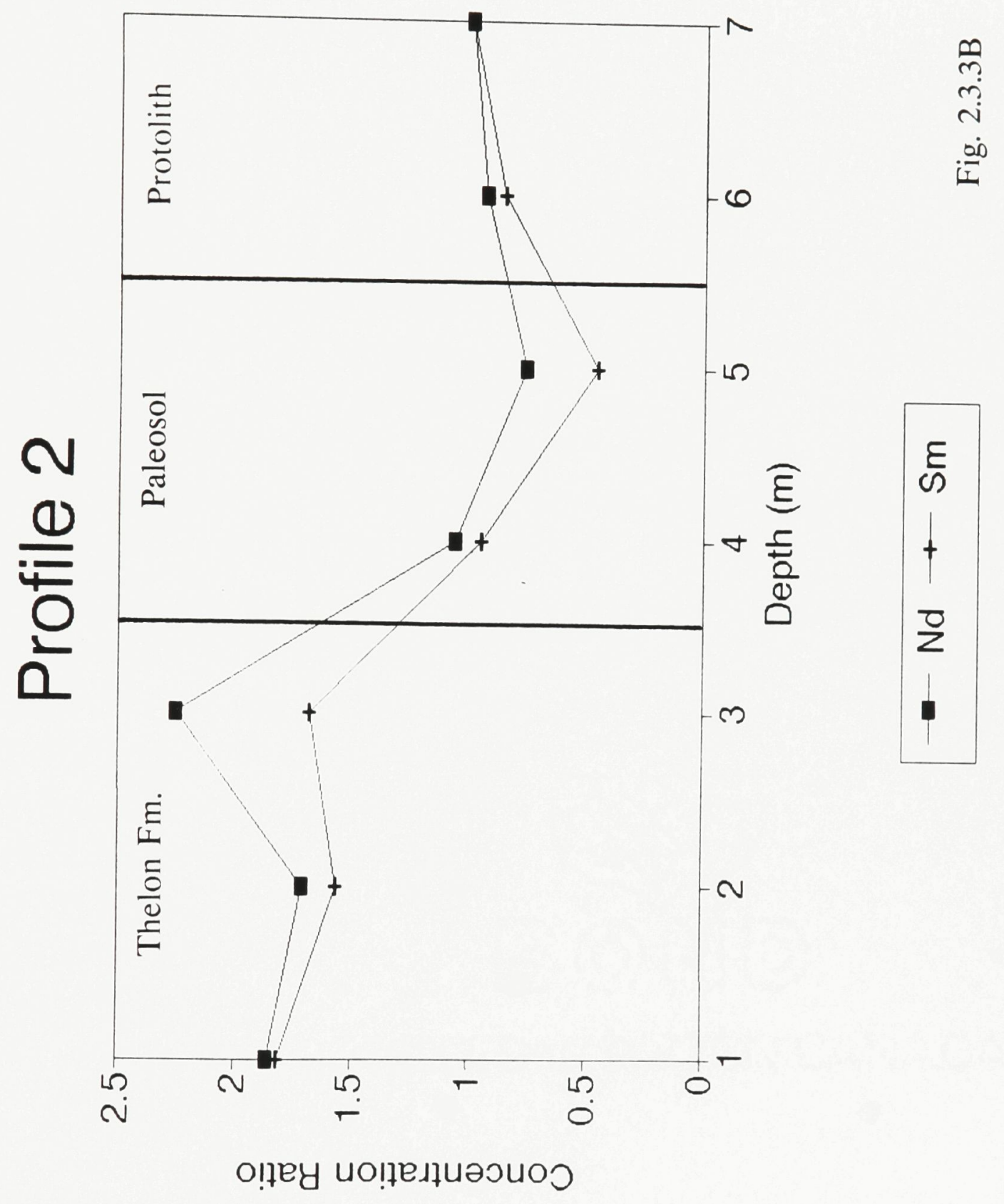




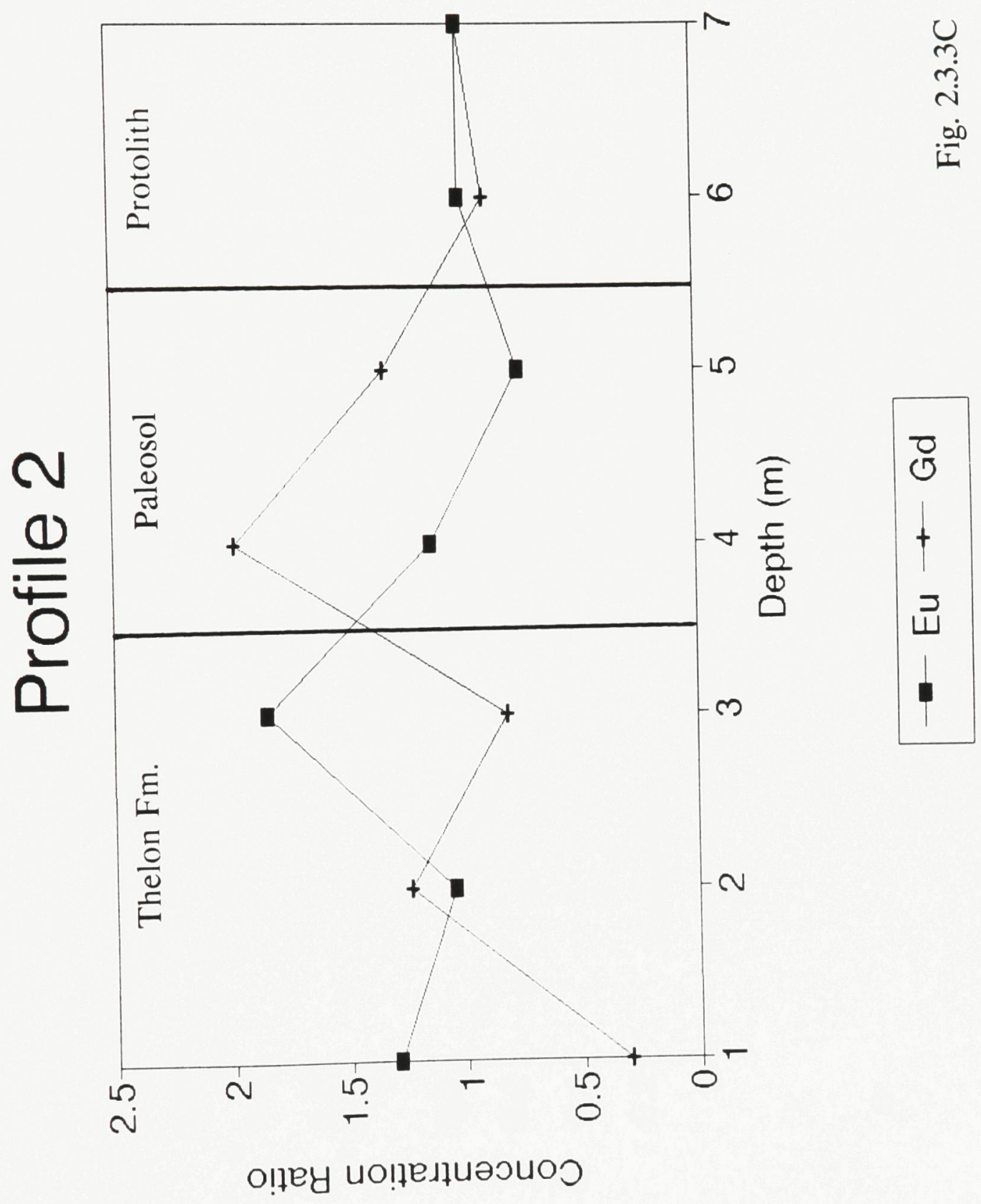




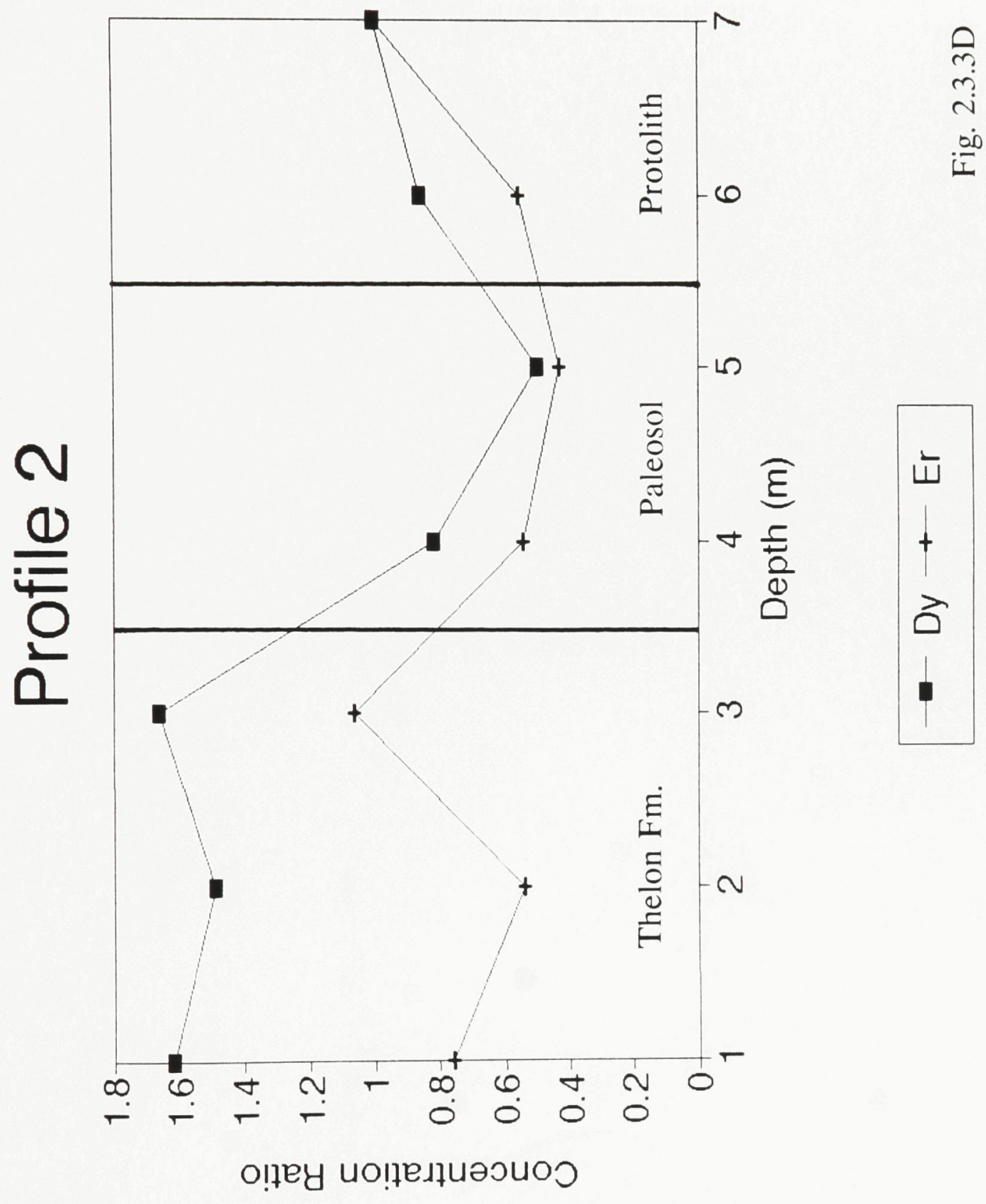




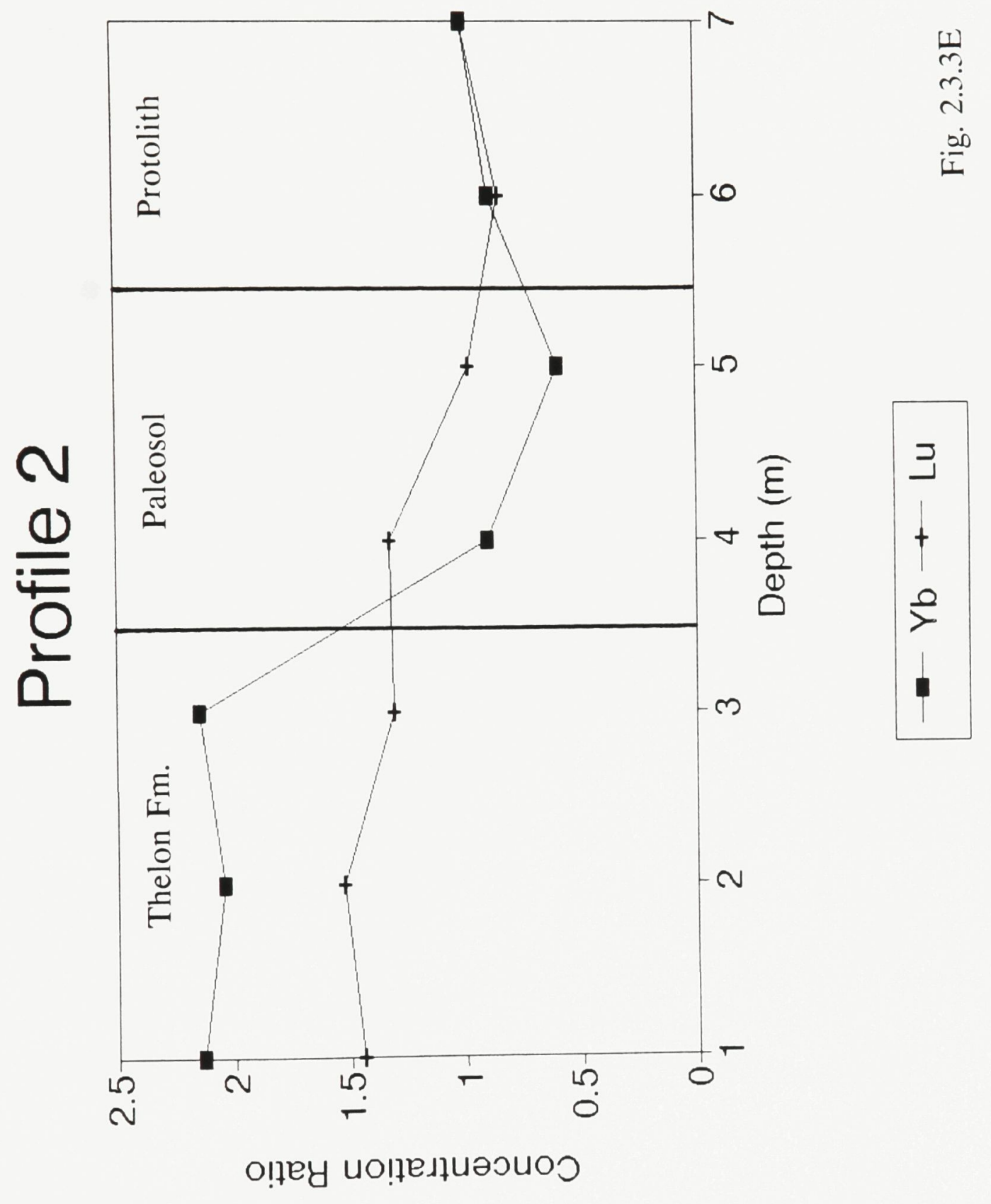




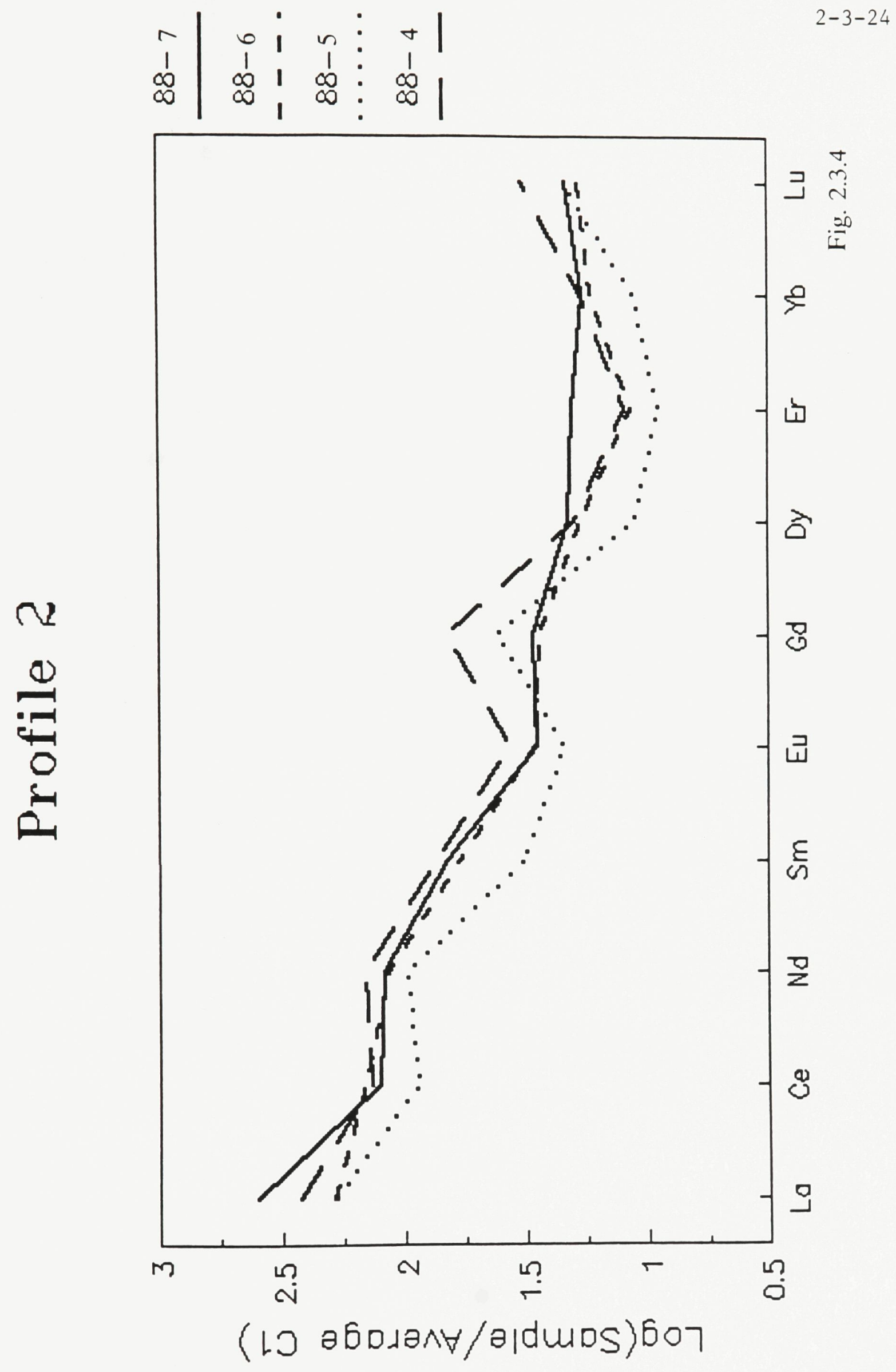




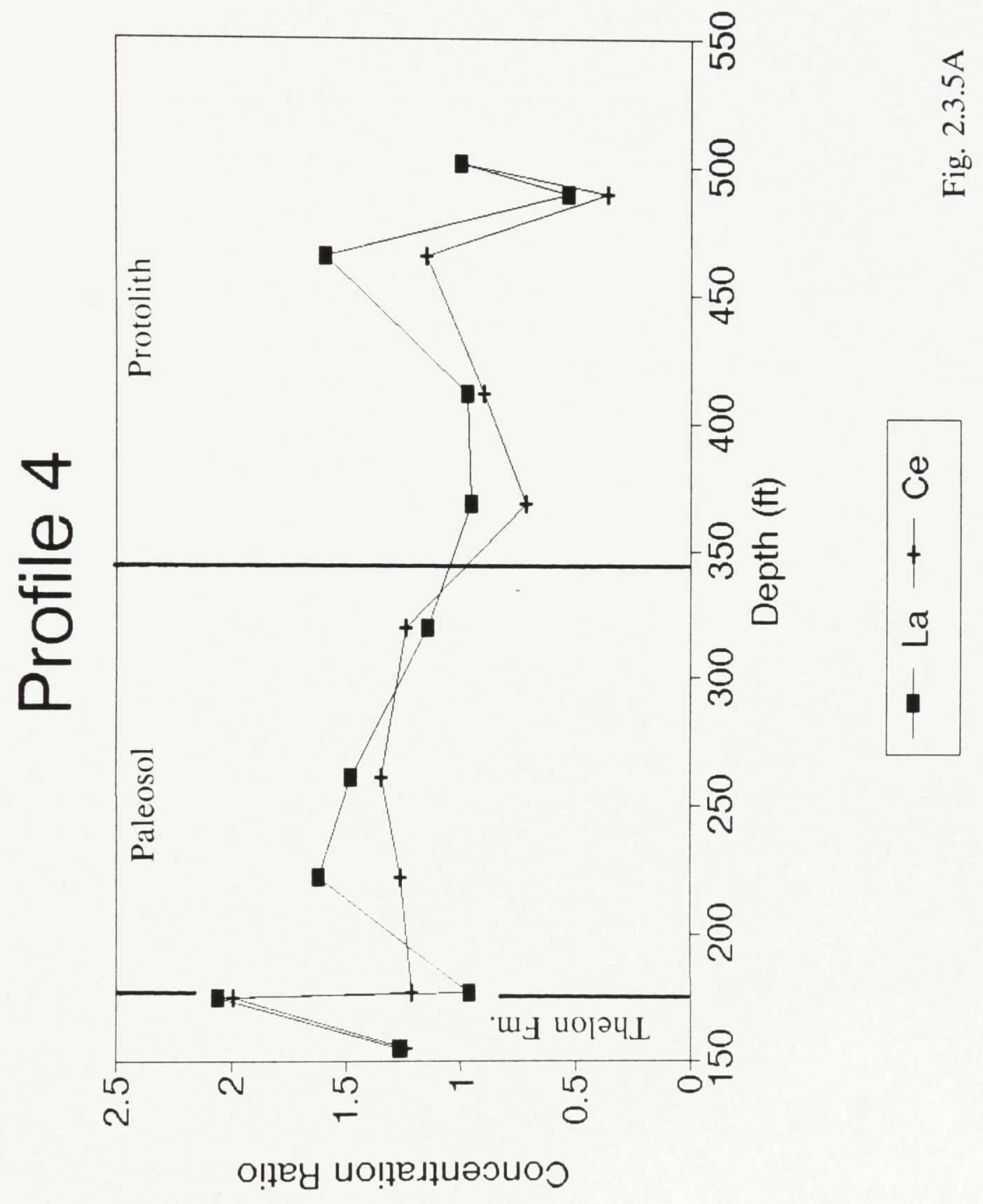




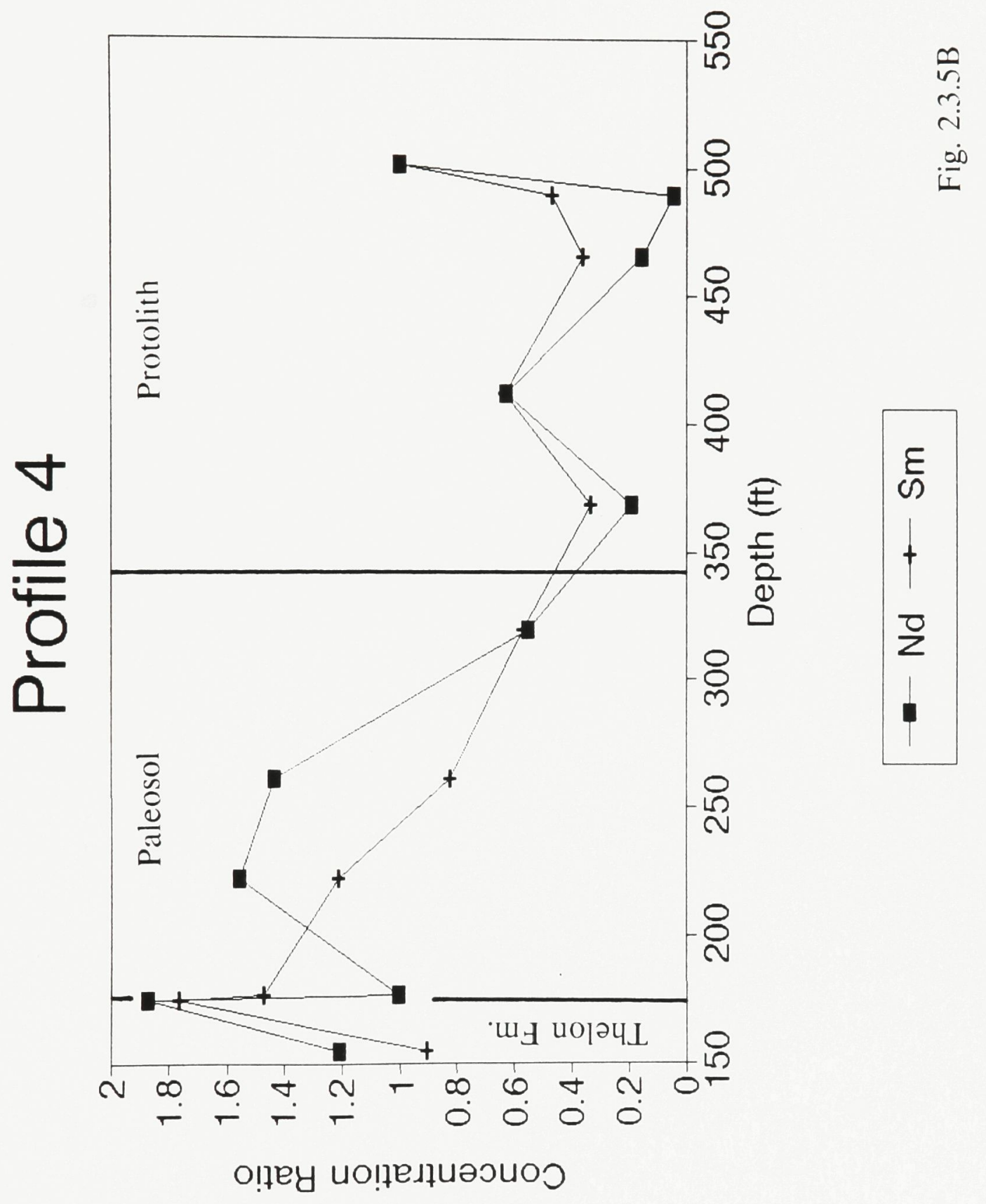




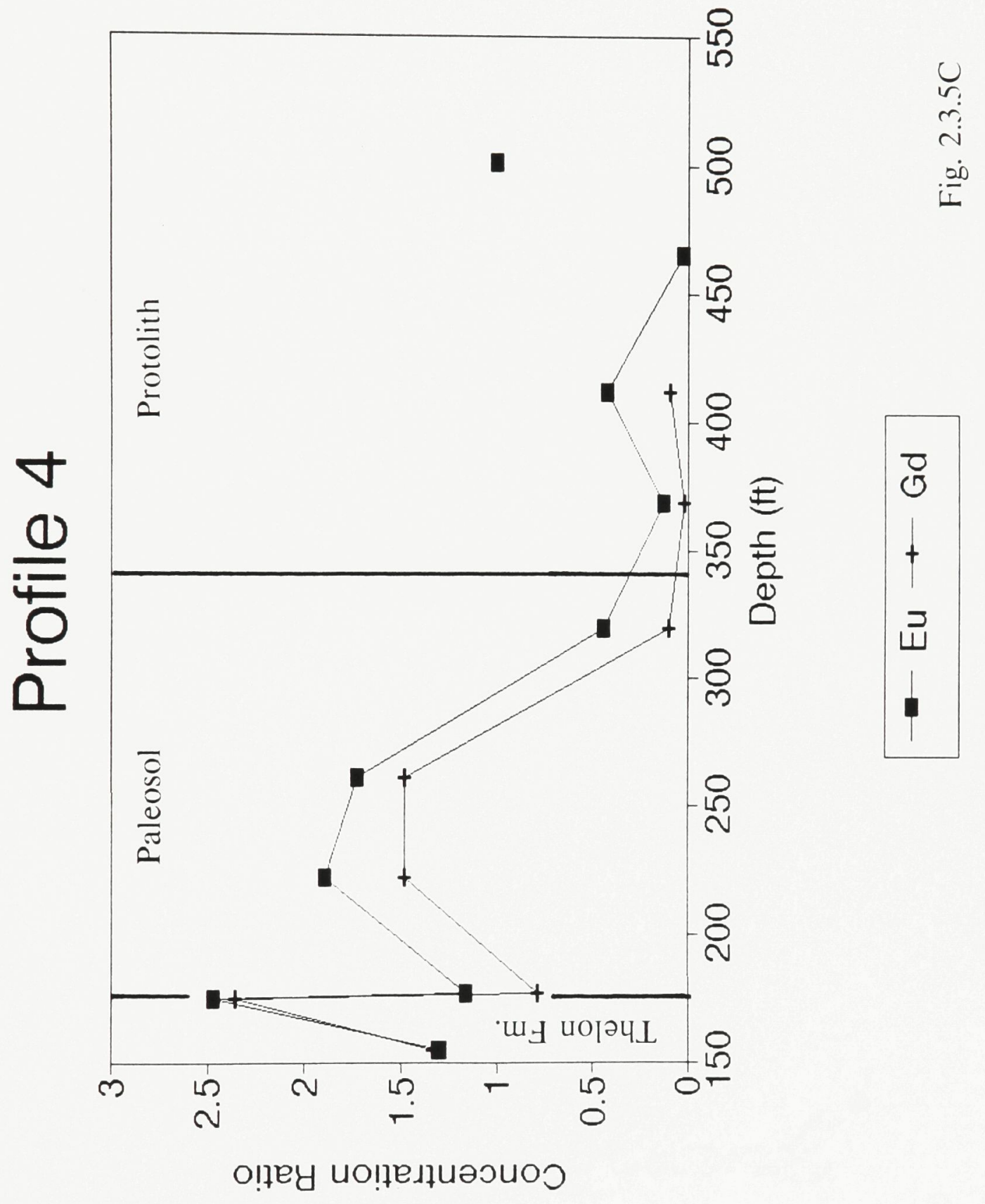




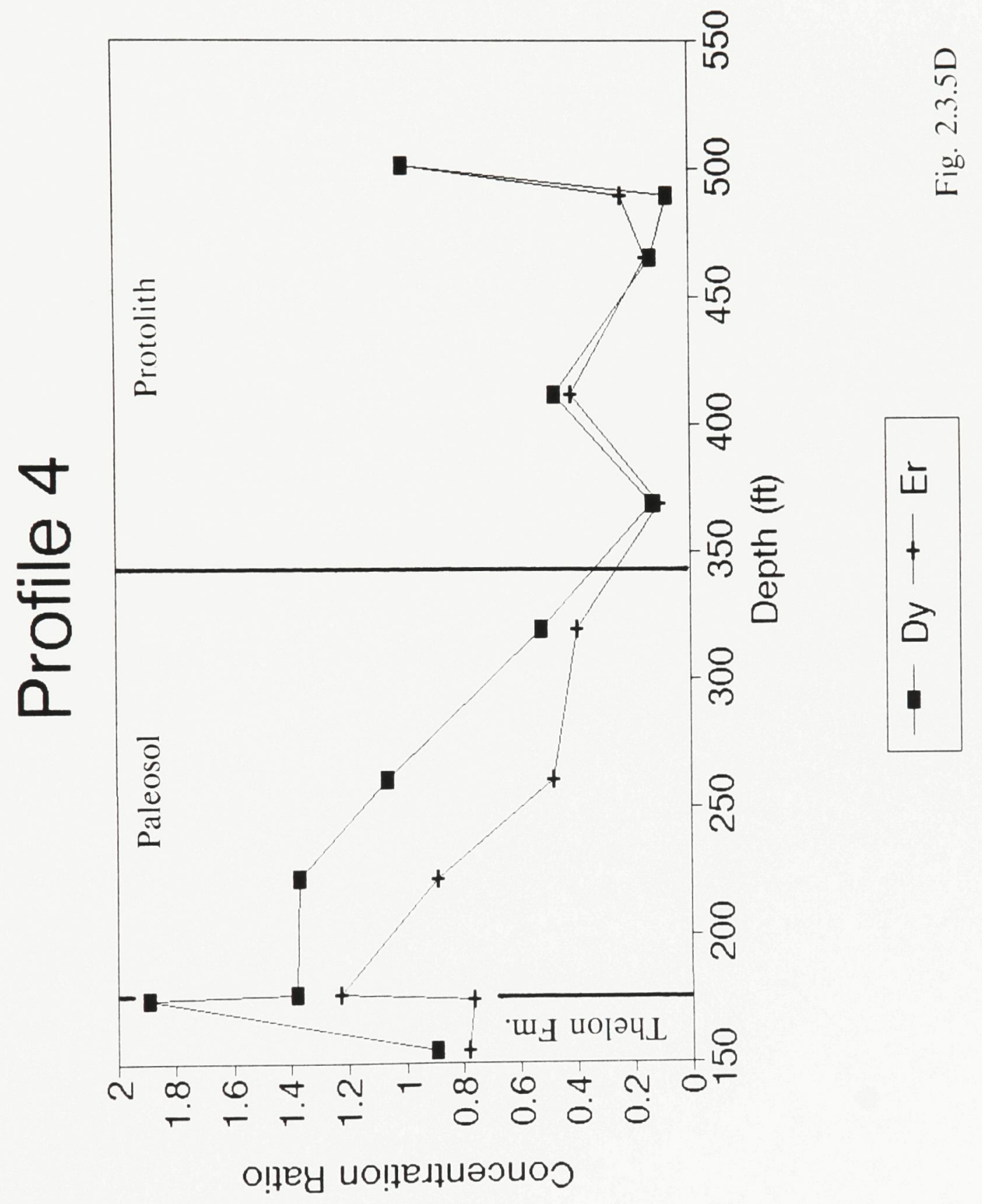




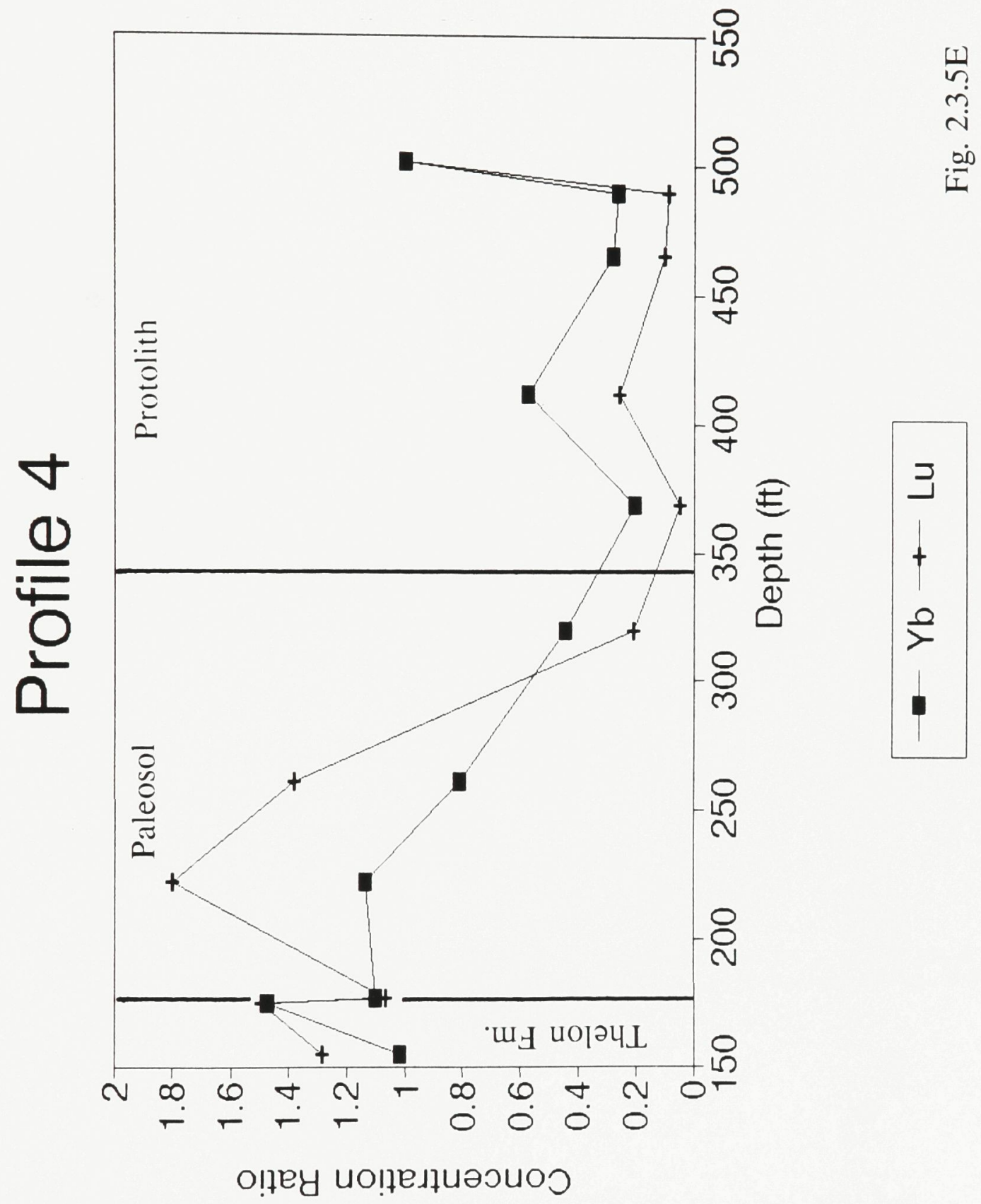




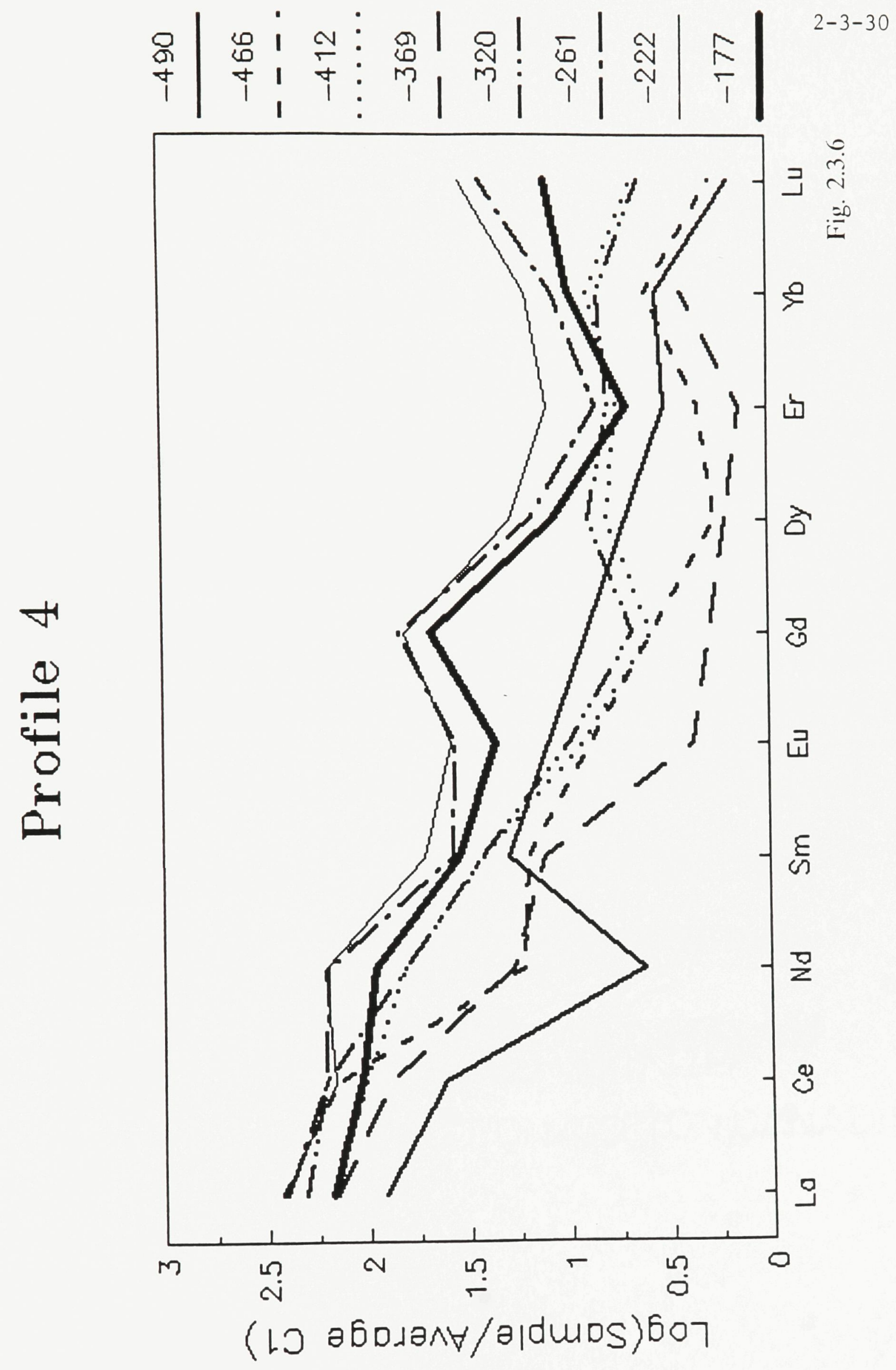




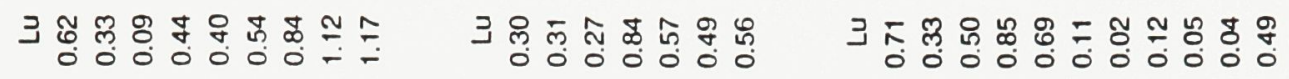

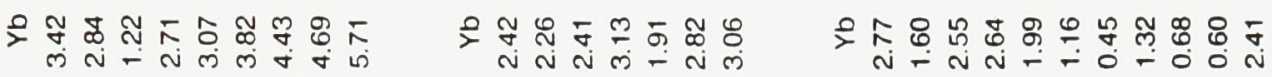

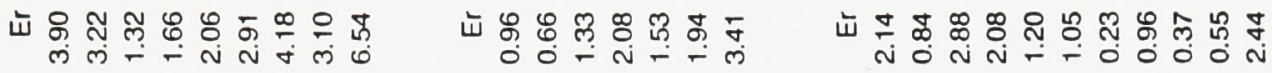

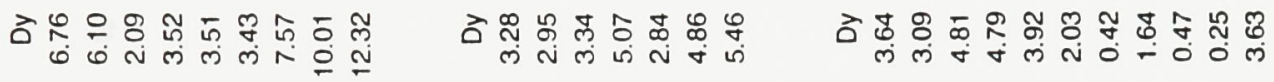

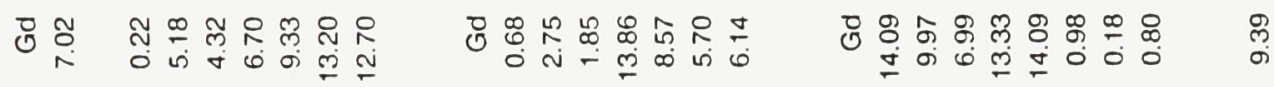

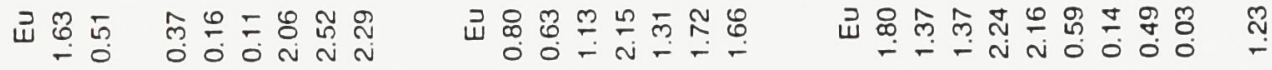

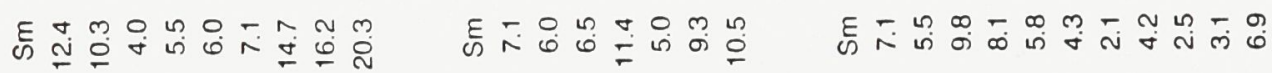

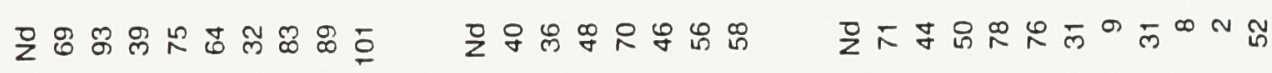

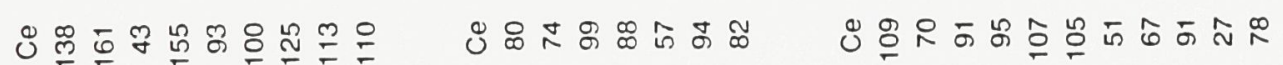

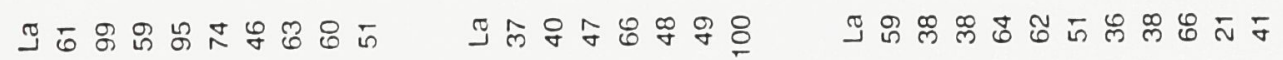

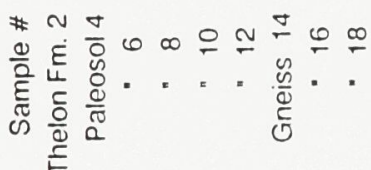

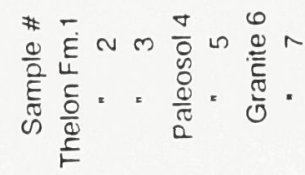

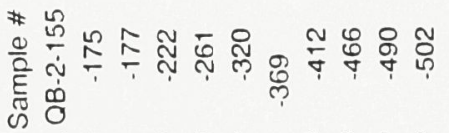
$\frac{0}{\frac{0}{2}}$
$E$
E.
$\frac{E}{0}$
$\frac{\text { D }}{F}$

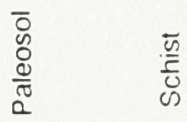




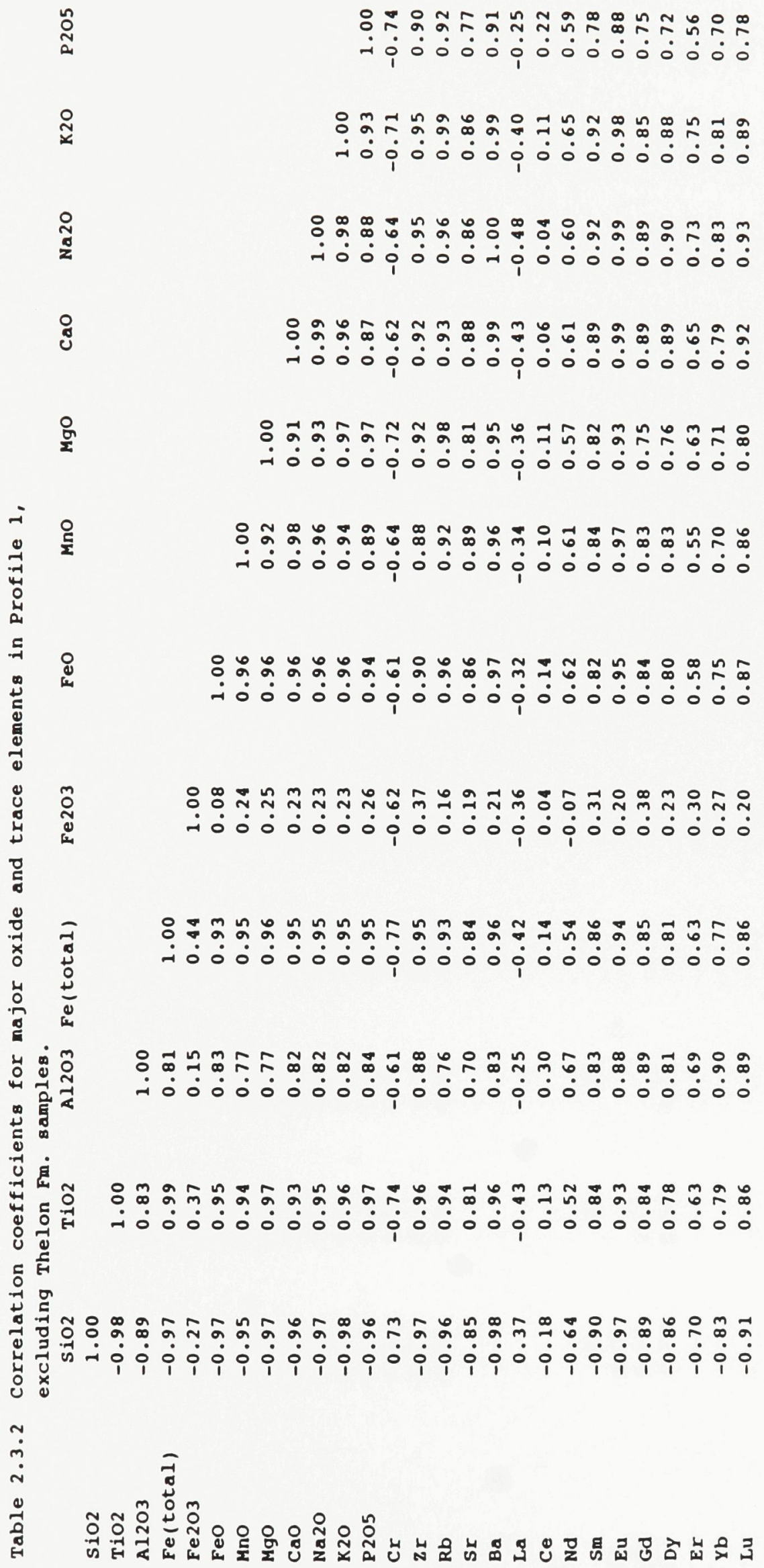


ตำ

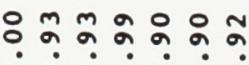

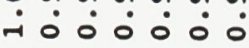

굴

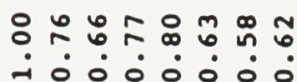

ฮั

ำกำ $-\dot{0}: 000000$

$\$$

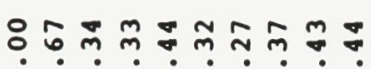
$-\dot{0} \dot{0} \dot{i}_{i} \dot{i}_{i} \dot{i} \dot{i}$

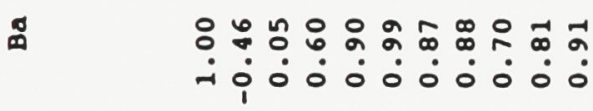

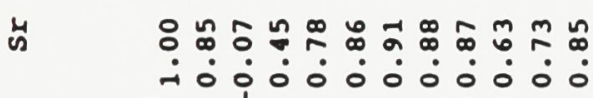

2 - $\dot{0} \dot{0} \dot{0} \dot{0} \dot{0} \dot{0} \dot{0} \dot{0} \dot{0} \dot{0} \dot{0} \dot{0}$

马ㄴ?

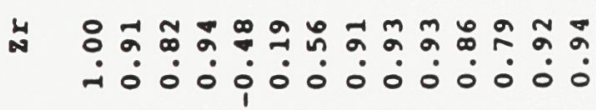

시 :

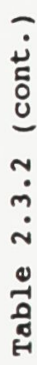

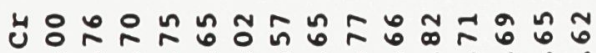
-i $\dot{i}_{i} \dot{i}_{i} \dot{i}_{i} \dot{i}_{i} \dot{i}_{i}$

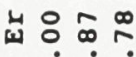
$\dot{i} \dot{0}$

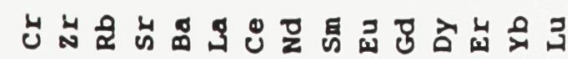

岗 위 


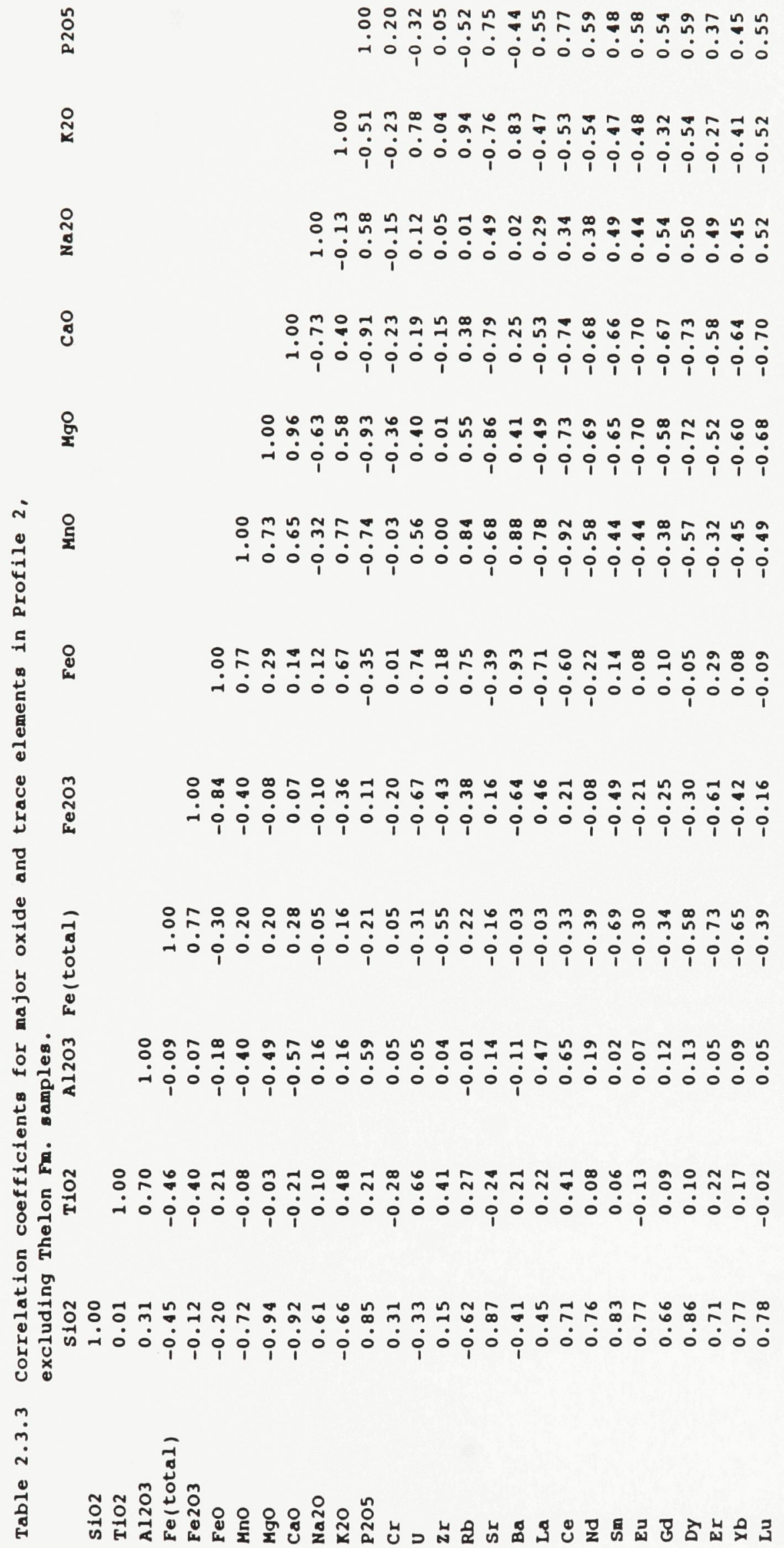




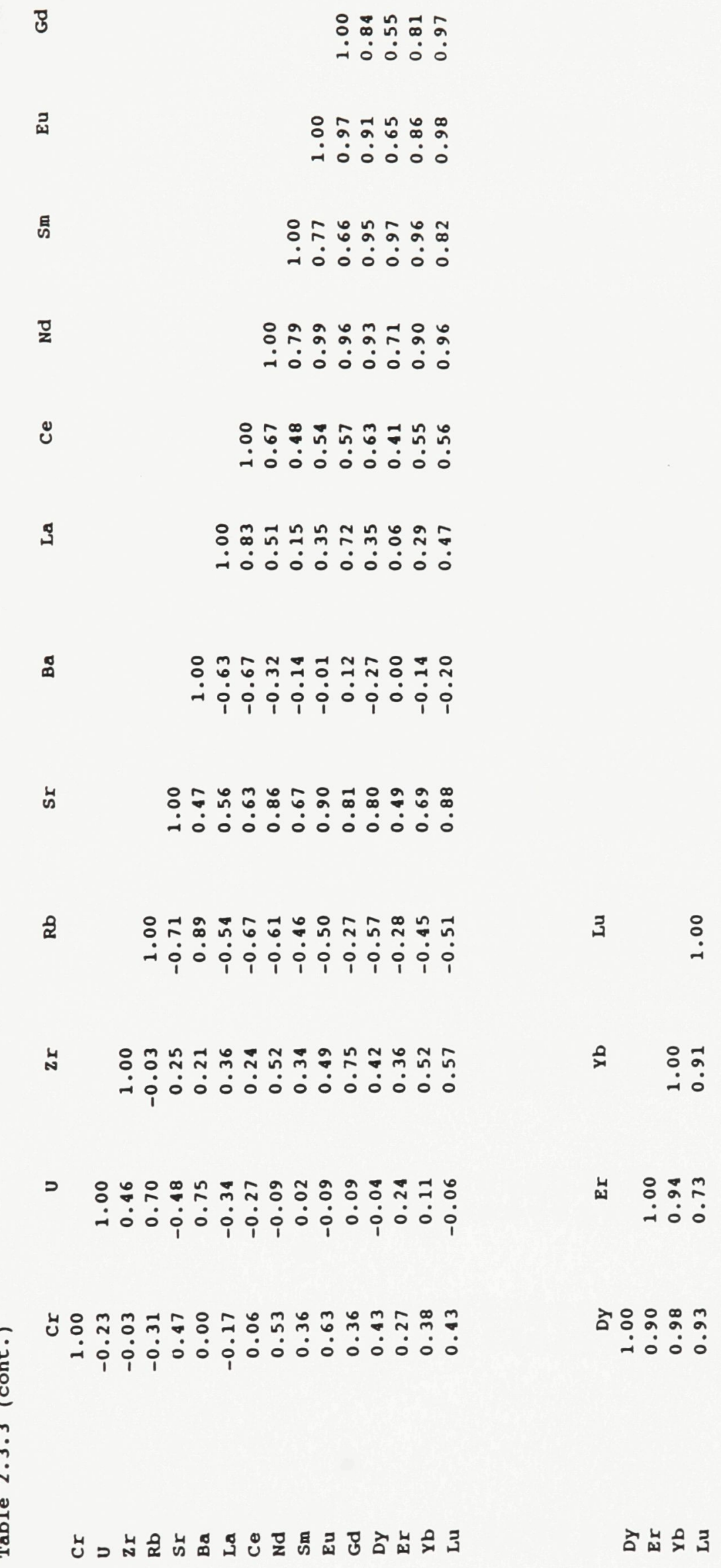




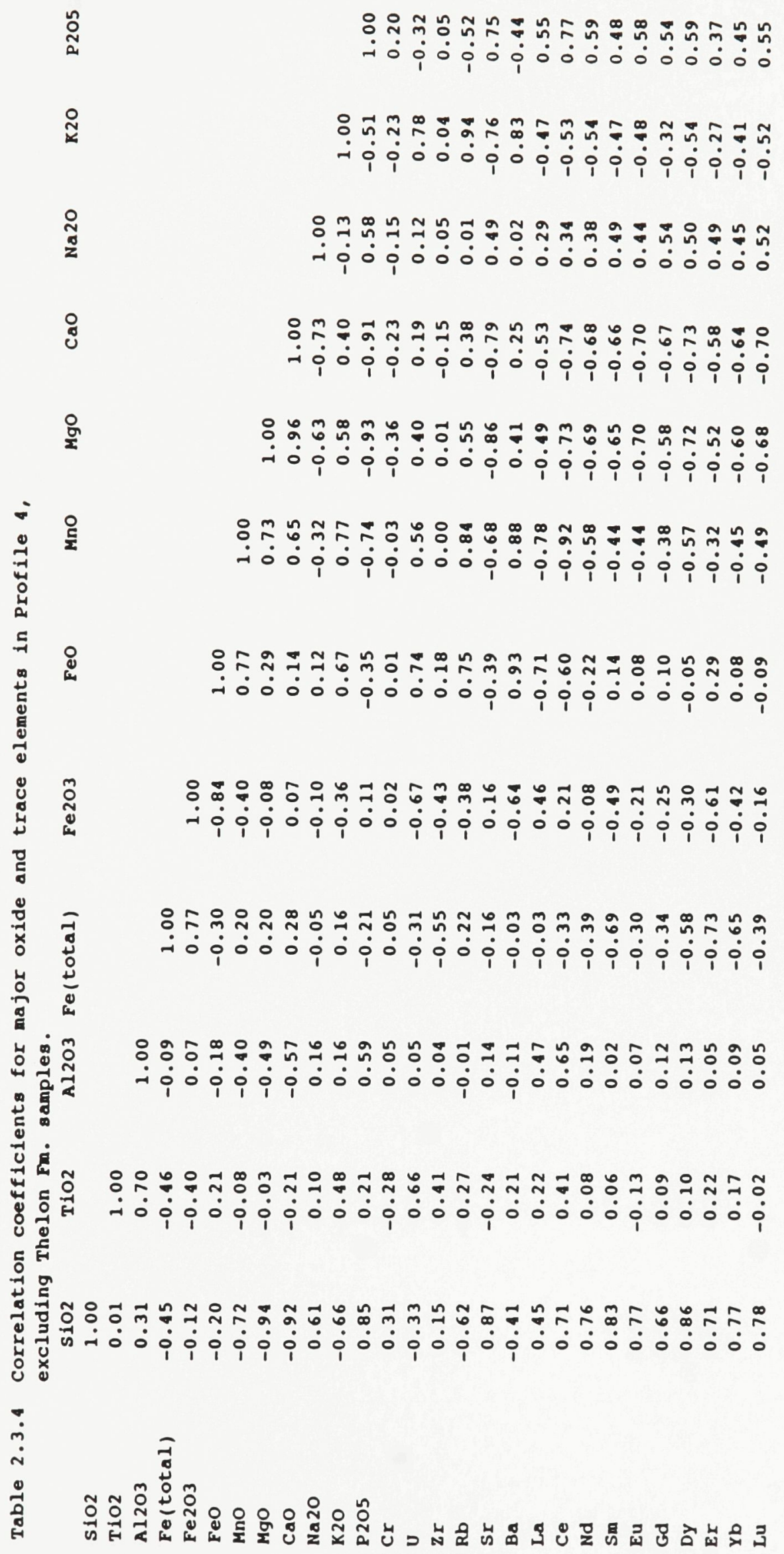


娄

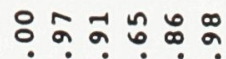
再:

帛 ำกํํำดัดูดั

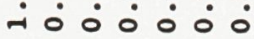

$\frac{\pi}{2}$ ำลํํำํํํำ

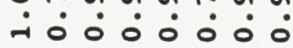

¿

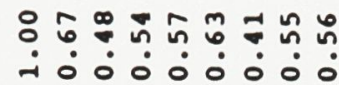

$\$$ ํํㅁำ -io: : : :

ळ

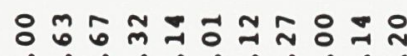

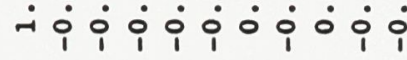

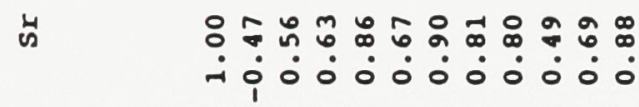

운

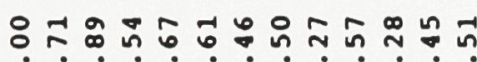

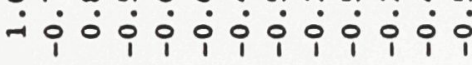

그

$\stackrel{8}{\circ}$

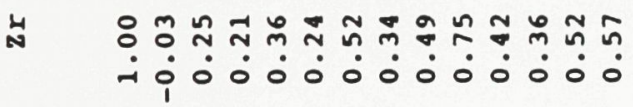

× $\stackrel{\circ}{\circ}: \overrightarrow{0}$

=

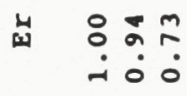

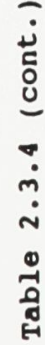

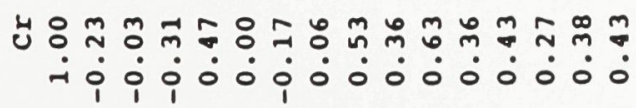

ไิํํㅇํำ

i。ำ

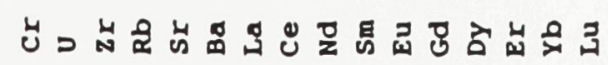

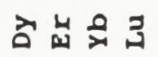




\section{CHAPTER THREE}

\section{SECTION ONE}

DIAGENESIS: THELON FORMATION AND

THELON PALEOSOL 


\section{INTRODUCTION}

The term diagenesis is used here, and throughout this thesis, to describe the physical and mineralogical changes which have occurred within the Thelon Formation and Thelon paleosol after weathering (i.e., during burial).

Thelon Formation diagenesis was studied for two principal reasons. First, diagenesis of the Thelon Formation sediments has not been extensively documented (e.g., Cecile, 1973; Munro, 1984). Second, to recognize diagenetic overprinting of the Thelon paleosol, it is imperative that diagenesis within the overlying Thelon Formation be characterized.

To this end, the diagenesis of 39 basal Thelon Formation sedimentary rocks has been studied where they have been encountered as part of the four widelyseparated profiles which were used to study the Thelon paleosol (Chapter 2), and from outcrops near the four profiles. The diagenetic minerals within these samples are described in the order in which they formed, thereby following the paragenetic sequence for these rocks. The sequence of mineral development is based on physical features such as the transection, alteration, and pseudomorphism of one mineral by another. Where possible, identifications and mineral compositions were determined by X-ray diffractometry, infrared spectroscopy, electron microprobe analysis, or energy-dispersive X-ray spectrometry (Appendix I). Illite crystallinity measurements have also been made on $<2 \mu \mathrm{m}$ micas, to further assess the diagenetic state of the 
basal Thelon Formation.

The Thelon Formation sandstone samples have a detrital mineralogy composed of the following: monocrystalline and polycrystalline quartz, potassic and plagioclase feldspar, muscovite and rock fragments. Generally, felsic volcanic rock fragments are more abundant than granitic, metamorphic or paleosol varieties. Based on point counts ( 300 points per thin section) of 25 sandstone samples from the base of the Thelon Formation (Table 3.1.1), the sandstone composition varies between subarkose and litharenite. Sandstone clasts are typically moderate to well sorted, and subangular to subrounded.

\section{DIAGENETIC MINERALS}

\section{QUARTZ CEMENT}

Quartz cement within the Thelon Formation samples consists of overgrowths on quartz grains, chert, and less commonly, megaquartz $(>2 \mathrm{~mm})$ and chalcedony. Unlike the coarser sandstone and conglomerate samples, quartz cement was not evident in siltstone and fine-grained sandstone samples.

Syntaxial quartz overgrowths (overgrowths in crystallographic continuity with framework quartz grains) can be distinguished from the host grains by intervening discontinuous dust rims (Fig. 3.1.1). The red coloration and finely crystalline nature of the dust rims suggests that they consist of trace amounts of iron oxide, and/or 
oxidized phyllosilicates which coated some grains, without inhibiting subsequent quartz cementation (cf. Heald and Larese, 1974). Quartz overgrowths are best developed in samples from profiles 2 and 3 . In these samples, the overgrowths are generally $<0.1 \mathrm{~mm}$ thick and have subhedral terminations against other overgrowths, grains, or kaolinite. In one sample (BL-15-103.85) the quartz overgrowths, which have euhedral terminations that are mostly free of inclusions, have occluded almost all of the interstitial space.

Generally, where chert is present, it has clearly formed after any quartz overgrowths (Fig. 3.1.2). Chert has an irregular distribution, and, in some samples, is the only occluding cement. In some samples from Profile 2, for example, chert is the dominant cement, with some grains appearing to be completely surrounded by chert. Where chert cement is abundant, the normally rounded grain boundaries are subtly embayed (Fig. 3.1.3), as though they have been corroded by the chert. Minor equant to drusy megaquartz has rimmed secondary pores in the chert cement of these samples (Figs. 3.1.8 and 3.1.9). Bladed to equant megaquartz has rimmed detrital grains in one sample from Profile 1 (171-2).

A few samples contain length-fast chalcedony. The chalcedony generally appears to have taken place after the chert cementation, because it commonly exists in a more interstitial position than the chert. In places, occluding chalcedony forms $<0.5 \mathrm{~mm}$-thick lamellae of fascicular fibres, separated by red oxide lamellae (Fig. 
3.1.4) that are similar in appearance to the oxidized dust rims between grains and quartz overgrowths.

\section{PHYLLOSILICATES}

\section{Kaolinite}

Kaolinite is present in trace amounts in all of the Thelon Formation samples examined. Typically, kaolinite occurs as vermiform books that occlude any interstitial space not filled during the earlier episode of quartz cementation. In thin section, where quartz cement coexists with kaolinite, the quartz cement invariably intervenes between detrital grains and kaolinite (Fig. 3.1.3). The books of kaolinite have a firstorder clear grey birefringence, and range from $<0.05$ to $0.5 \mathrm{~mm}$ long.

In a few samples, kaolinite is in direct contact with detrital grains. Where it is in contact with feldspar, some feldspar grains display corroded, vague grain boundaries and the books of kaolinite appear to blend into the feldspar (Fig. 3.1.5). This intimate relationship suggests that at least some kaolinite may have formed authigenically as a result of feldspar dissolution.

X-ray diffractograms of the clay fraction from the Thelon Formation samples indicate that the main kandite group mineral is well ordered triclinic kaolinite. In a mineralogical study of a few Thelon samples, Dean (1967) identified kaolinite, dickite and nacrite. Some samples from this study produced XRD peaks that suggest 
the presence of monoclinic dickite. However, examination of the kandite group mineral extracted from Thelon Formation samples in Profile 2 and near Profiles 1 and 4 , including analysis of clay minerals in a sample from the same site from which nacrite was previously reported (DF-298-65; Dean, 1967), using infrared spectroscopy (Appendix I), clearly shows that the mineral is kaolinite. Figs. 3.1.6 and 3.1.7 show examples of infrared spectra from two Profile 1 samples (DF-5 and DF-1), including an enlargement of the 3200 to $3800 \mathrm{~cm}^{-1}$ range. The 3700 to $3600 \mathrm{~cm}^{-1}$ range shows the characteristic absorbtion pattern for the hydroxyl group in kaolinite (Kodama, 1985; pers. comm. 1992), which is distinct from that of nacrite and dickite (Newnham, 1961): essentially, $\%$ transmitance $3694.0 \mathrm{~cm}^{-1}>3620.0 \mathrm{~cm}^{-1}$ for nacrite and dickite, and $\%$ transmitance $3694.0 \mathrm{~cm}^{-1} \approx 3620.0 \mathrm{~cm}^{-1}$ for kaolinite.

Electron microprobe analyses of kaolinite in three Thelon Formation samples (Table 3.1.2), reveal that they contain minor amounts of potassium and iron. These elements could represent minor amounts of illitized kaolinite and hematite which has replaced some of the kaolinite.

In two of the eight samples of Thelon Formation sandstone collected in the Marjorie Hills near Profile 1, the kaolinite was morphologically distinct from that identified in all other Thelon Formation samples. Kaolinite in these two samples occurs as blades (0.1-0.3 mm wide, $0.5-0.8 \mathrm{~mm}$ long), which span irregularly-shaped pores within the quartz cement (Fig. 3.1.8). Rarer, more tabular kaolinite crystals 
that display simple twinning (Fig. 3.1.9) are also present. Electron microprobe analyses of the bladed kaolinite (Table 3.1.2), X-ray diffraction data (Gandolphy and powder diffractometry), and infrared spectroscopy, do not chemically or crystallographically distinguish the bladed- to tabular-kaolinite from the typical triclinic vermiform kaolinite observed in other Thelon Formation samples.

Generally, the kaolinite is pseudomorphed by illite fibres (Fig. 3.1.10), which typically grow parallel to the basal plane of the vermiform books. The illitized kaolinite is also cut by fluorapatite, the APS mineral, and hematite (e.g., Fig. 3.1.19).

Illite

As originally defined by Grim et al. (1937), "illite" refers to clay-size phyllosilicates with lattice structure and petrographic properties that are very similar to micaceous minerals. Illite is predominantly dioctahedral, and on average it contains more $\mathrm{Si}, \mathrm{Mg}$ and $\mathrm{H}_{2} \mathrm{O}$, but less $\mathrm{K}$, than muscovite (Dunoyer De Segonzac, 1970).

Illite is absent in some Thelon Formation samples, but generally is present in trace to minor amounts. The illite typically consists of slender fibres to slightly broader needles, $<0.1$ to $0.2 \mathrm{~mm}$ long, that are highly birefringent and colourless in plane-polarized light. The illite occurs as unoriented interstitial fibres or needles, 
and as fringes on detrital feldspathic grains (Fig. 3.1.11). Rare bundles and rosettes of illite are also developed. In most samples, the fibrous interstitial illite is pseudomorphous after vermiform kaolinite (Fig. 3.1.10), with illite fibre growth parallel to individual kaolinite plates, or, less commonly, between intergrown kaolinite books.

An attempt was made to identify mica polytypes using X-ray diffractograms, diagnostic X-ray diffraction lines (Bailey, 1980, p. 58), and the following $2 \mathrm{M}_{1} /\left(2 \mathrm{M}_{1}\right.$ $+1 \mathrm{M}_{\mathrm{d}}$ ) illite polytype ratios where possible: $\mathrm{I}(3.745 \AA$ ) $/ \mathrm{I}(2.58 \AA$ ) (Velde and Hower,

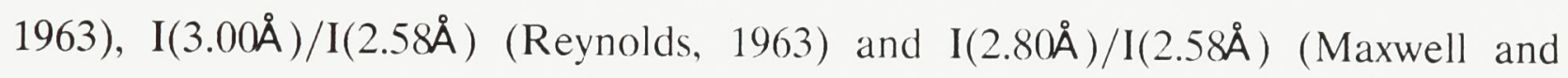
Hower, 1967). Dioctahedral illite was identified by the presence of a (060) $1.49 \AA$ peak (Bailey, 1980).

Illite is absent in Profile 2 and is only a minor constituent (although both $1 \mathrm{M}$ and $2 \mathrm{M}$ polytypes can be identified) in the other Thelon Formation samples. Within the paleosol and unweathered protolith samples, both dioctahedral and trioctahedral $2 \mathrm{M}$ illite prevail, with $1 \mathrm{M}$ illite occurring in a few paleosol samples from the tops of Profiles 3 and 4 .

To help assess the degree of diagenesis in the basal Thelon Formation, the crystallinity of illite (Kubler, 1967; Dunoyer De Segonzac, 1970) from the Thelon Formation samples was estimated on the basis of basal $10 \AA$ reflections. It has 
generally been demonstrated that the crystallinity of illite increases (half height $10 \AA$ peak width decreases) as diagenetic conditions proceed towards metamorphic conditions. For this study, although no standard $\Delta^{0} 2 \Theta$ values are available for fixing the upper and lower anchizone boundaries, the instrumental settings (Appendix I) are comparable with those compiled by Kisch $(1983,1990)$ from a number of illite crystallinity studies. Such a comparison suggests that the instrument settings used in this study are similar to Kubler's Neuchatel settings, which place the diagenetic zone - anchizone boundary at $0.42 \Delta^{0} 2 \Theta$, and the anchizone - epizone boundary at 0.25 $\Delta^{0} 2 \theta$.

Esquevin (1969) noted that the crystallinity of illites not only depends on recrystallization temperature, but also on composition of the octahedral layer. Esquevin determined that aluminous (dioctahedral) micas reflect changing temperatures much more efficiently than ferromagnesian (trioctahedral) micas, and that the relative intensity of the $5 \AA$ (002) peak and $10 \AA$ (001) peak could be used to distinguish dioctahedral and trioctahedral micas respectively, as originally suggested by Nagelschmidt (1937). For this reason, illite crystallinity determinations have been plotted against $\mathrm{I}(002) / \mathrm{I}(001)$ measurements for the same sample.

The Thelon Formation samples in Profile 1 did not produce measurable XRD mica peaks. The remaining paleosol and gneiss protolith samples produced uniform illite crystallinity measurements of $0.2 \Delta^{0} 2 \Theta$, from both trioctahedral ( $\mathrm{I}(002 / \mathrm{I}(001)$ 
$<0.4)$ and dioctahedral micas $(\mathrm{I}(002) / \mathrm{I}(001)>0.4)$ (Table 3.1.3). The Thelon Formation samples in Profile 2 did not contain illite. Profile 2 paleosol and granite protolith samples produced illite crystallinity measurements between 0.10 and 0.40 $\Delta^{0} 2 \Theta$, but most did not produce $5 \AA$ (002) peaks (Table 3.1.3).

Illite crystallinity measurements plotted against intensity ratios of the (002)/(001) mica peaks for Profile 3 samples, show a weak positive correlation (Fig. 3.1.12). Samples from gneiss protolith and the incipiently weathered base of the paleosol yielded micas of biotite to phengite composition within the anchizone field, whereas samples from higher in the paleosol and from the Thelon Formation yielded more aluminous, muscovite-like micas which plot within the diagenetic field. This trend suggests that: (a) the Thelon Formation samples have remained within the diagenetic realm $\left(<200^{\circ} \mathrm{C}\right.$ : Kisch, 1987), and (b) paleoweathering and diagenesis produced more aluminous illite.

A similar plot for the Thelon Formation samples in Profile 4 places them within the diagenetic field or within the anchizone near the boundary between the anchizone and diagenetic zones (Fig. 3.1.13). The paleosol and schist protolith samples all fall within the anchizone field. All but one sample have a $(002) /(001)>0.4$, suggesting that most samples contain aluminous dioctahedral micas. 
Chlorite

Minor amounts of chlorite are present in 7 of the 39 Thelon Formation samples collected from above the paleoweathering profiles and adjacent areas. In these seven samples, detrital chlorite exists as blades, up to $0.5 \mathrm{~mm}$ long, displaying diffuse to frayed grain margins. The chlorite grains are commonly sandwiched and bent by impinging detrital grains. In a few cases, variations in birefringence and pleochroism suggest that some grains may be chloritized detrital biotite. Rare occurrences of interstitial, unoriented, fibres of chlorite are interpreted as nondetrital authigenic chlorite. These more delicate fibres are individually $<0.1 \mathrm{~mm}$ in length, but may form intergrown mats which occlude much of the immediate porosity. Their green colour in plane-polarized light, and a duller, second-order birefringence, serves to distinguish them from the diagenetic illite.

Possibly due to the small amounts of chlorite in the few chlorite-bearing Thelon Formation samples, X-ray diffractograms for these samples do not display strong chlorite peaks, especially between $2.70 \AA$ and $1.77 \AA$, the range where diagnostic XRD peaks can be used to distinguish between chlorite polytypes (Bailey, 1980, p.90). However, a few Thelon Formation samples from Profile 3 do display (002) peaks which are stronger than (003) peaks, and also show distinct $(060) 1.54 \AA$ peaks, suggesting that Fe- and Mg-rich trioctahedral chlorite is present in these samples. 
Fluorapatite cement has been previously identified in other Thelon Formation sandstone and Thelon paleosol samples (Miller, 1983; Miller et al., 1989). As described in Chapter Two, Miller et al. (1989) have used the fluorapatite cement to date Thelon Formation phosphate diagenesis. As well, Dean (1967), Cecile (1973) and Miller (1983) have identified goyazite within Thelon Formation sandstone and Thelon paleosol samples. Goyazite has not been identified in the Thelon Formation samples from this study. In this study, phosphatic minerals have been identified in basal Thelon Formation samples from Profiles 3 and 4; from Eyeberry Lake 50 kilometres north of Profile 3 (Fig. 2.1.1), and from Marjorie Hills (Fig. 2.2.1) just north and west of Profile 1. Using petrographic, electron microprobe, and energydispersive spectral analyses, these minerals have been identified as fluorapatite, and also a rare hydrated alumino-phosphate-sulphate mineral (APS). Because the APS mineral is a new occurrence of a relatively rare group of minerals, it is described in more detail than the other diagenetic minerals.

Petrographically, the fluorapatite occurs interstitially as either blocky cement (Fig. 3.1.14), or prismatic blades up to $0.75 \mathrm{~mm}$ long (Fig. 3.1.15); both forms locally occlude pore space. The blocky cement has a typical first-order grey blue birefringence, whereas the bladed cement has a slightly lighter first order clear grey birefringence. Compositionally, the blocky and bladed varieties are very similar (Table 3.1.4). In a number of samples, the bladed fluorapatite has an elongate core consisting of euhedral pits separated by walls of fluorapatite (Figs 3.1.15 and 3.1.16). 
Energy dispersive spectra of the pits (e.g., Fig. 3.1.17 core) show that they contain elemental carbon, sulphur and chlorine, compared to the normal fluorapatite composition of the rest of the crystal (Fig. 3.1.17 rim).

The APS mineral occurs as 4 to $15 \mu \mathrm{m}$ euhedral crystals which are typically square in section (Figs. 3.1.18 and 3.1.19). They occur either isolated, or as intergrown crystal aggregates. The APS mineral has a first order blue grey birefringence, and a yellowish white colour in plane polarized light. Its optical sign cannot be determined due to the small crystal size.

The general crystal chemistry of the APS mineral was determined using energy-dispersive X-ray analysis (EDX). A typical EDX spectrum of a crystal rim is shown in Fig. 3.1.20. Table 3.1.5 shows 10 core, 4 intermediate, and 7 rim EDX analyses from 16 crystals in two thin sections. Using the general isostructural formula for the alunite-jarosite family of minerals, $\mathrm{AB}_{3}\left(\mathrm{XO}_{4}\right)_{2}(\mathrm{OH})_{6}($ Botinelly, 1976; Scott, 1987), formulae for the analyses in Table 3.1.5 were calculated, and are presented in Table 3.1.6. A wide variety of A-site substitution is evident, and includes light rare earth elements (LREE). Ba, Ca, Ce, Sr, Nd and $\mathrm{La}$ are present in the cores, intermediate zones and rims of crystals. Th does not occur in the rims of crystals, and $\operatorname{Pr}$ was detected in only one crystal. Al typically substitutes for minor amounts of $\mathrm{Fe}^{3+}$ in $\mathrm{B}$ sites. 
Concentric zonation of grey hues is evident when some APS crystals are viewed using back-scattered electron imagery (Fig. 3.1.21). As revealed by energydispersive spectra (EDS) during analytical traverses across some crystals (Fig. 3.1.22), the zonation reflects subtle variations in $\mathrm{Al}, \mathrm{Sr}, \mathrm{S}$, Th and REE concentrations. However, the subtle variations in crystal composition cannot be quantified, because the zonation is on a scale that is finer $(0.5-1.0 \mu \mathrm{m})$ than the analytical width of the EDX beam $(\sim 2 \mu \mathrm{m})$. Therefore the formulae in Table 3.1.6 must be considered as being derived from average rim, intermediate zone and core compositions.

The effect of $\mathrm{Sr}$ and $\mathrm{Ca}$ A-site substitution and variation in $\mathrm{SO}_{4}$ and $\mathrm{PO}_{4}$ in the crystals can further be depicted in an alunite-goyazite-crandallite ternary plot (Fig. 3.1.23). Figure 3.1.23 indicates that the APS crystal chemistry has an intermediate composition between woodhouseite and svanbergite (beudantite group), and crandallite and goyazite (crandallite group). Due to this intermediate composition in the alunite-goyazite-crandallite ternary plot, these APS crystals have not been named. Scott (1987) has suggested that mineral names not be assigned to mineral compounds with such complex A-, B- and $\left(\mathrm{XO}_{4}\right)$ substitutions.

The APS mineral is superimposed on grain boundaries, quartz overgrowths, kaolinite and illitized kaolinite, but is cut and corroded by the hematite cement. It has not been observed in contact with the fluorapatite cement. Where both occur in the same thin section, fluorapatite occurs as rims on detrital grains, and the APS 
mineral occupies a more central interstitial position. Assuming that pore occlusion took place from grain boundaries towards the pore centres, this spatial relationship suggests that the APS mineral formed after the fluorapatite.

\section{HEMATITE CEMENT}

Most of the samples of Thelon Formation sandstone and conglomerate contain minor amounts of hematite cement, whereas siltstone and mudstone samples typically contain more hematite cement and, as a result, commonly appear reddened compared to adjacent beige sandstone. Hematite in the coarse-grained samples is dark red to opaque, and finely crystalline. It occurs both interstitially and on altered detrital grains (Fig. 3.1.24). Bladed opaque hematite crystals, up to $0.25 \mathrm{~mm}$ long, are less common (Fig. 3.1.25). Distribution of the hematite cement in the coarser samples is typically patchy, and probably marks areas where iron-bearing minerals have been oxidized.

In thin section, it is evident that the hematite cement cuts all other diagenetic minerals. Rarely, recrystallized illite appears to have grown across the hematite cement. As well, open microfractures and illitic veinlets cut the hematite cement and, on a millimetre scale, appear to have allowed removal of much of the adjacent hematite. Reduction spots are also evident in hand samples and thin sections, but are not obviously connected to the open microfractures or veinlets. 
Because of the abundance of hematite cement in the fine-grained rocks, the relationship of hematite cement to other diagenetic minerals in these rocks is not obvious. In a few samples, quartz veinlets cut the hematite cement. As well, hematitized siltstone and mudstone lithic fragments, subsequently cemented by quartz and phyllosilicates, have been identified in some conglomerate samples. These features suggest that much of the hematite in the fine-grained Thelon Formation samples may have formed earlier than hematite cement in the sandstone and conglomerate samples (i.e., before quartz cementation), and therefore may have formed at the same time as oxidized dust rims in the coarse-grained samples.

\section{DISCUSSION}

\section{THELON FORMATION DIAGENESIS}

Within the 39 Thelon Formation samples from the four widely-spaced paleoweathering profiles and adjacent outcrops, there is evidence for both physical and mineralogical diagenetic change.

Physically, grains within samples from all four profile areas exhibit sutured to concavo-convex grain-to-grain boundaries. Two samples from near Profile areas 1 and 2 exhibit stylolites. These types of grain contacts, and stylolitization, are attributed to pressure solution in deeply buried sediments (Taylor, 1950; Pittman, 1972; Blatt et al., 1980; Turner, 1980). Some of the silica which contributed to formation of quartz overgrowths in the Thelon Formation samples may have been 
produced by pressure solution as a result of quartz-grain compaction. Grain compaction and overgrowth development may have led to partial collapse and filling of primary porosity in the basal Thelon Formation sediments.

Petrographic features suggest that grain-to-grain compaction and stylolitization occurred at different times. The association of interpenetrating grain-to-grain contacts with quartz overgrowths which developed early in the paragenetic sequence, suggests that grain-to-grain compaction also occurred during early diagenesis. Furthermore, stylolites in the basal Thelon Formation cut interstitial kaolinite, which post-dates quartz cementation, whereas most stylolites contain illite and hematite, suggesting that they formed after kaolinitization, but during or before illitization and hematitization. Grain-to-grain compaction and quartz cementation thus appears to have preceeded kaolinitization and subsequent stylolitization.

Mineralogically, the diagenetic minerals, and their paragenesis, are consistent in all four sample areas. A composite paragenesis for the diagenetic minerals within Thelon Formation samples described in the previous section is shown in Fig. 3.1.26. Consistently, quartz cementation is followed by phyllosilicate formation (kaolinite, chlorite and illite respectively), and finally, by hematite cementation. Fluorapatite and APS cementation occurred in all areas except in and near Profile 2 north of Dubawnt Lake. Except for the APS mineral, all of the diagenetic minerals are widely developed within the Thelon Basin (Cecile, 1973; Miller, 1983; Donaldson, 
1969), as is dolomite (Cecile, 1973; Munro, 1984) which is not present in samples from the four sample areas. However, it has been included in the paragenetic sequence, because inspection of drill core and thin sections from the Eyeberry Lake area shows that dolomite cement is a major constituent, and that it formed after fluorapatite cement and before hematite cement. The discussion below considers the way in which each diagenetic mineral in the study area may have formed.

Quartz cementation occurred first, commencing with epitaxial quartz overgrowths, followed by chalcedony, $0.1-0.5 \mathrm{~mm}$ microquartz or chert. Why one form of silica locally persists rather than another is unclear. The presence of quartz overgrowths on grains which display grain-to-grain contacts where no overgrowths exist (Fig. 3.1.1), suggests that local $(<5 \mathrm{~mm})$ dissolution and precipitation of silica may have occurred. This mechanism of quartz overgrowth development, from pressure solution between quartz grains, has been described by Trurnit (1968) and Robin (1978). The only other plausible source for silica would be from the dissolution of labile silicate grains, which are noticeably absent within most samples. An increase in impurity concentration in the diagenetic fluid may have promoted chert formation (Millot, 1970). Conversely, an increase in the concentration of silica in the diagenetic fluid may have promoted chalcedony and microquartz formation (Thiry and Millot, 1987). It is generally agreed that quartz cementation takes place under conditions of $\mathrm{pH}<9$, when dissolved silica in the diagenetic fluid is greater than 6 ppm (at $25^{\circ}$ C) (Krauskopf, 1956; Blatt, 1979; Blatt et al., 1980). Similar 
conditions are invoked for quartz cementation in the Thelon Formation.

Kaolinite growth followed quartz cementation, and, like the quartz cement, kaolinite is present in most Thelon Formation samples. Regardless of whether the kaolinite is bladed, blocky, or veriform, it has occluded most secondary porosity that remained after quartz cementation. Perhaps the levels of silicon in pore fluids remained high enough ( $>1 \mathrm{ppm}$, Hurst and Kunkle, 1985) after quartz cementation to promote kaolinite formation. Kaolinite on corroded feldspar grains suggests that some silicon and aluminum for growth of the kaolinite may have come from feldspar dissolution, perhaps as a result of hydrolysis. The kaolinite is obviously authigenic rather than detrital for the following reasons: (a) the growth of kaolinite on corroded detrital feldspar grains, (b) the delicate, intergrown nature of the kaolinite would not survive transportation, and (c) a lack of discrete granular (transported) texture.

Generally, conditions that would have promoted kaolinite formation include a low pH (4 to 7), high Eh, and low cation activity (other than silica and aluminum) (Garrels and Christ, 1965; Davies et al., 1979; Almon and Davies, 1979; Blatt et al., 1980; Hurst and Kunkle, 1985). The persistence of kaolinite in the Thelon Formation samples, rather than dickite or nacrite, suggests that the rocks have not been subjected to temperatures $>200^{\circ} \mathrm{C}$ (anchimetamorphic temperatures) (Dunoyer De Segonzac, 1970; Kisch, 1987). 
As stated, diagenetic chlorite in the Thelon Formation samples is either absent or a minor constituent. The only information that can be gleaned from the delicate fibres is that they are iron- or magnesium-rich. The mechanism by which the diagenetic trioctahedral chlorite has formed is not clear. There is no strong evidence to suggest that it formed at the expense of kaolinite (e.g., Hutcheon et al., 1980); all that can be suggested is that local increases in cation activity in the diagenetic fluid promoted the development of minor amounts of chlorite. In his regional study of the Thelon Basin, Cecile (1973) described more widespread diagenetic aluminous dioctahedral chlorite from stratigraphically higher beds; however, dioctahedral chlorite is not abundant in samples from this study.

As described, illite in the Thelon Formation samples is poorly crystalline and aluminous, and all of the illite that has replaced kaolinite occurs interstitially. Relatively minor amounts of illite occur as an alteration product on detrital grains. The illitization of kaolinite can be easily achieved by increasing the potassium concentration in the diagenetic fluid (Garrels and Christ, 1965; Velde, 1965; Blatt et al., 1980; Nesbitt and Young, 1989). Minor amounts of other cations in the diagenetic fluids (e.g., Mg, Fe; Blatt et al., 1980) may have also been incorporated into the illite as it grew.

Illitization of the kaolinite is not considered to be a direct reaction between seawater and kaolinite via halmyrolysis (e.g.. Mackenzie and Garrels, 1966; Maynard, 
1975), because there is evidence that the sediments were subjected to some burial diagenesis before illite formation. Instead, the illite likely formed in buried parts of the Thelon Formation where basinal brines, rich in potassium, altered the kaolinite to illite. There is ample evidence that illite formation is more common in deeper parts of buried sedimentary sequences as a consequence of higher temperatures $\left(80^{\circ}\right.$ to $150^{\circ} \mathrm{C}$ ), and the reaction of potassic brines with precursor phyllosilicates (Velde, 1965; Dunoyer de Segonzac, 1970; Heling, 1974; Hower et al., 1976; Hanor, 1979; Bethke and Marshak, 1990). In particular, Hancock and Taylor (1978) and Eriksson and Soegaard (1985) have attributed the replacement of kaolinite by illite to potassium metasomatism by diagenetic fluids.

In the study samples, phyllosilicate growth was followed by the formation of fluorapatite and the alumino-phosphate-sulphate mineral (APS). Although volumetrically minor, these minerals are widespread within the Thelon Basin, especially in the lower part of the Thelon Formation above the basal unconformity.

Generally, varieties of apatite in sedimentary rocks are commonly associated with marine phosphorite deposits (Bentor, 1980; Baturin, 1982; Burnett and Riggs, 1986), and less commonly with lacustrine deposits (Love, 1964; Swirydczuk et al., 1981), guano deposits (Cook, 1984), and weathering profiles (Espenshade and Spencer, 1963; Trueman, 1965; Altschuler, 1973; Dahanayake and Subasinghe, 1989). The fluorapatite in the Thelon Formation does not closely fit any of these settings, 
primarily because the lower part of the Thelon Formation is not associated with a marine environment, or with obvious organic activity, and cannot be directly linked to paleoweathering. Pitted cores of the bladed fluorapatite contain anomalous amounts of $\mathrm{S}, \mathrm{Cl}$ and $\mathrm{C}$, suggesting that a sulphate mineral may have existed before the fluorapatite formation. This may account for the uncommon bladed morphology of these fluorapatite crystals. The ratio of $\mathrm{C}: \mathrm{O}$ in the cores of the bladed fluorapatite is too high for the carbon to be attributable only to carbonate carbon, and thus some carbon in the core may have an organic origin.

Phosphorous in the fluorapatite in the Thelon Formation samples has no obvious source. Because phosphorite deposits have yet to be found in the Barrensland Group to which the fluorapatite might be diagenetically linked, the phosphorous might ultimately have come from a weathered basement lithology. Christopher Island Formation volcanic rocks have the highest phosphate content of any basement rocks in the region, and are generally anomalously high in comparison to most other igneous rocks (Peterson, 1992). It has been paleoweathered, and it contains fluorapatite that may have been dissolved during weathering, providing a source for basic diagenetic solutions (cf. McKelvey, 1973), from which fluorapatite could have precipitated as cement in the Thelon Formation. Precipitation from phosphorous-rich diagenetic fluids is therefore proposed to account for fluorapatite cementation in the Thelon Formation. 
Unlike apatite group minerals, occurrences in sedimentary rocks of beudantite group minerals, crandallite group minerals, or minerals of intermediate composition, are rare. Most occurrences of these minerals have been interpreted as products of weathering or hydrothermal alteration (McKie, 1962; Espenshade and Spencer, 1963; Trueman, 1965; Vieillard et al., 1979; Blount, 1974; Lefebvre and Gasparrini, 1980; Stoffregen and Alpers, 1987). A diagenetic origin has been ascribed to only a few occurrences (Young, 1958; Russell and Trueman, 1971; Ross, 1983; Wilson, 1985a; Spötl, 1990). The widespread distribution of APS minerals in the Thelon Formation and their occurrence as euhedral crystals developed midway through the diagenetic sequence, suggests that they are diagenetic.

Some studies suggest that aluminum phosphates typically form by the alteration of apatite by acidic solutions in the absence of carbonates (Zanin, 1968; Altschuler, 1973; Nriagu, 1976; Lindsay, 1979; Flicoteaux and Lucas, 1984; Banfield and Eggleton, 1989). Aluminum in many of these examples likely was derived from phyllosilicates such as kaolinite by local dissolution (Altschuler et al., 1956; Zanin, 1968; Golterman, 1973). Close spatial association in the Thelon Formation samples of the APS mineral, corroded fluorapatite, and kaolinite, suggests that, similar to aluminum phosphates, local dissolution of the fluorapatite and kaolinite contributed to formation of the APS mineral. Furthermore, the sulphur in the mineral may have come, at least in part, from cores of the bladed fluorapatite grains, where dissolution pits and anomalous sulphur contents have been identified. Furthermore, the 
presence of minor amounts of $\mathrm{A}$-site light rare earth elements ( $\mathrm{La}, \mathrm{Ce}, \mathrm{Pr}, \mathrm{Nd}$ ) in the APS mineral suggests that it was formed from acidic solutions (cf. Burkov and Podporina, 1967; Nesbitt, 1979; Duddy, 1980; Sholkovitz, 1989;), probably with a low $\mathrm{HCO}^{-}{ }_{3}$ content (cf. Herrmann, 1978). The presence of LREE in the diagenetic APS mineral refutes the suggestion of Fleet (1984) that REE are unaffected by diagenesis.

The final diagenetic mineral to develop was hematite. Its intragranular and intergranular distribution, as well as the presence of a few hematitized iron-bearing grains, together suggest a diagenetic rather than a detrital origin. Some of the hematite likely was formed by the in-situ oxidation of iron in detrital grains and in early-developed diagenetic minerals. Studies by Walker (1967a, 1967b) on this form of hematitization have led to the general recognition (Blatt et al., 1980) that hematite typically forms from oxidized, acidic meteoric fluids. However, all that can be deduced for hematite cement in the Thelon Formation samples is that it formed in an oxidizing diagenetic environment.

The preceding discussion of diagenetic minerals, and their paragenesis, within the basal Thelon Formation sandstone, can be summarized as follows. The basal Thelon Formation is, in general terms, a continental alluvial-fluvial sequence (Gall et al., 1992). The formation and sequential development of oxidized dust rims, quartz cement, and kaolinite in the basal Thelon Formation samples is typical of early diagenetic changes brought about by oxidized, acidic meteoric fluids in 
continental sandstones (e.g., Keller, 1970; Bucke and Mankin, 1971; Füchtbauer, 1974; Turner, 1980; Hurst and Irwin, 1982; Gall and Hiscott, 1986; Eslinger and Huff, 1987; Eslinger and Pevear, 1988; Girard et al., 1989; Surdam et al., 1989; Girard and Deynoux, 1991). Such diagenetic changes, that appear to be linked to surface or near-surface processes, have been referred to as eogenesis by Burley et al. (1985). The apparent development of quartz overgrowths from grain-grain compaction and pressure solution suggests that quartz cementation was a consequence of sediment burial. The subsequent development of chlorite and poorly crystalline aluminous illite indicates that the activity of cations, particularly potassium, has increased within the diagenetic fluids. Such diagenetic changes in the phyllosilicates are common in the mesogenetic regime (Burley et al, 1985) where buried clastic sequences have been isolated from surface or near-surface processes. Minor but widespread development of apatite, and the subsequent development of dolomite elsewhere in the Thelon Basin, indicate that diagenetic solutions had become alkaline. Phosphate cementation was followed by formation of the APS mineral, suggesting that, at least locally, acidic conditions prevailed. The final diagenetic change involved oxidation and hematitization of basal sandstones of the Thelon Formation. This late oxidation may reflect regional uplift of the Thelon Formation into near-surface oxidizing conditions. This final diagentic change may be equivalent to telogenesis as described by Burley et al. (1985).

Apart from the fluorapatite, which formed at about 1720 Ma (Miller et al., 
1989), the ages of the diagenetic minerals in this paragenetic sequence are not known. Only the relative order in which they were formed can be presented (Fig. 3.26). The only indication of the temperatures to which these sandstone samples where subjected during diagenesis comes from illite crystallinity measurements, which suggest that temperatures during illite formation did not surpass $200^{\circ} \mathrm{C}$. Using the present maximum thickness for the Barrensland Group of approximately two kilometres (Overton, 1971), and a conservative paleogeothermal gradient for the cratonic Thelon Basin of $25^{\circ} \mathrm{C} / \mathrm{km}$, the minimum temperatures to which basal Thelon Formation would have been exposed as a result of burial alone would be $50^{\circ} \mathrm{C}$. A comparison of the paragenetic sequence of phyllosilicates in the basal Thelon Fm. sandstones to the paragenesis of typical mineral assemblages developed in arenaceous rocks affected by diagenesis, anchimetamorphism, or epimetamorphism (Kisch, 1983; Frey, 1987), supports the inference that the Thelon assemblage formed within the diagenetic realm.

The diagenetic changes in the basal Thelon Formation sandstones are very similar to the diagenetic changes seen in correlative basal sandstones from the Hornby Bay Basin and Elu Basin (Chapter Four). Although there have been more diagenetic studies of similarly correlative arenaceous rocks within the Athabasca Basin, only a few such studies have described the diagenesis in areas unaffected by unconformity-type uranium mineralization. Within the Athabasca Group sandstones, early dust rims and quartz overgrowth development is generally followed by 
phyllosilicate growth, and then by late stage hematite (Hoeve et al., 1981; Wilson, 1985b; Kotzer et al., 1992). Fluorapatite and goyazite (Wilson, 1985a, 1985b) also occur throughout the Athabasca Group sandstones, but their paragenesis does not conform to that in the Thelon Formation. Fluid inclusions in quartz overgrowths (Pagel et al., 1980), stable isotope analyses of phyllosilicates and hematite (Kotzer et al., 1992), illite crystallinity measurements (Hoeve et al., 1981, Wilson, 1985b), all suggest that the Athabasca Group sandstones, like the basal Thelon Formation sandstones, have remained within the diagenetic realm, and have been altered by diagenetic fluids with a maximum temperature between $150^{\circ} \mathrm{C}$ and $200^{\circ} \mathrm{C}$.

\section{THELON PALEOSOL DIAGENESIS}

Within a buried sequence containing a paleosol, any changes such as diagenesis, metamorphism or deformation, will obscure original pedogenic features. Studies by Al-Gailani (1981), Mensing and Faure (1983), Velbel (1985), Haynes (1988), Duffin et al. (1989), Harper et al. (1991), and Liliak and Ceci (1991), all suggest that basinal (diagenetic) fluids commonly alter underlying 'basement' lithologies along basal unconformities. As discussed in Chapter One (Gall, 1992), using Precambrian examples, there is evidence that paleosols along basal unconformities also become diagenetically overprinted. Diagenesis of paleosols within sedimentary sequences has also been documented (e.g.. Lander et al., 1992). The likelihood that diagenetic overprinting will affect a paleosol increases with geologic age; and so, as pointed out by Wright (1992) and Gall (1992), it is critical 
to identify and 'remove' such overprinting before true pedogenic features can be identified. Fortunately, despite its antiquity, the Thelon paleosol has only been affected by local high-angle faulting, which has not affected the study samples.

Structurally, as described in Section One of Chapter Two, stylolites are developed within the paleosol in Profile 2. The stylolites locally deform paleosol grains and interstitial minerals, and may contain illite that is slightly coarser than elsewhere in the samples. These stylolites, which are generally subparallel to the sub-Thelon Formation unconformity, are interpreted as having formed during progressive burial of the paleosol, at the same time as those within the Thelon Formation.

Geochemically, there also is evidence that the Thelon paleosol was overprinted by diagenetic fluids. Some of Thelon paleosol profiles show anomalous ascending element gains near the unconformity, which are contrary to the typical ascending depletion trends for paleoweathering, and are not associated with residual accumulations or illuviations. Ascending gains of $\mathrm{SiO}_{2}$ and $\mathrm{Fe}_{2} \mathrm{O}_{3}$ within Profile 1 are attributed, at least partly, to the presence of quartz and hematite veinlets, respectively, which cut Thelon paleosol minerals. Quartz-and hematite-bearing veins also cut the Thelon Formation, and as discussed in Section One of Chapter Two, all of these veinlets are considered to have formed during Thelon Formation diagenesis. In Profiles 2 and 4, sympathetic ascending increases in $\mathrm{P}_{2} \mathrm{O}_{5}$ and $\mathrm{Sr}$ are interpreted 
to reflect the presence of the diagenetic APS mineral within the paleosol. The similarity in morphology, concentric zoning, and composition of the APS mineral within paleosol and Thelon Formation samples in Profile 4, and growth of the APS mineral on other mineral grains within the paleosol samples, strongly suggest that the same diagenetic fluids which formed the APS mineral within the Thelon Formation also formed the APS mineral within the paleosol.

As depicted in Fig. 3.1.26, both the Thelon paleosol and Thelon Formation samples may contain one or more similar phyllosilicates. Because, as described above, there is evidence for diagenetic overprinting of the Thelon paleosol by diagenetic fluids emanating from the Thelon Formation, and because the same types of phyllosilicates (kaolinite, chlorite, illite) are present in both settings, the possibility that the phyllosilicates within the Thelon paleosol are a result of diagenetic overprinting of the paleosol, rather than pedogenesis alone, must be evaluated.

Kaolinite, chlorite and illite are developed in the Thelon paleosol and the Thelon Formation. The small size of the phyllosilicates, and their 'masking' by hematite cement, make them difficult to physically and chemically characterize. However, a variety of features collectively suggests that variable amounts of kaolinite, chlorite and illite formed first during paleoweathering, and again as a result of diagenesis within the Thelon Formation. The main features which suggest coexistence of both pedogenic and diagenetic phyllosilicates are summarized below, and 
in Table 3.1.7.

Texturally, vermiform kaolinite exists in both paleosol and Thelon Formation samples; however, bladed kaolinite only occurs within the Thelon Formation. Kaolinite is a common interstitial component in the Thelon Formation, compared to the paleosol where it either is a minor component or is absent. Kaolinite within the Thelon Formation typically is associated with, and immediately post-dates, quartz cementation. Unfortunately, X-ray diffraction, infrared spectroscopy and electron microprobe analyses of kaolinite could not distinguish between kaolinites from the two settings.

Texturally, illite is typically fibrous and pseudomorphous after vermiform kaolinite within both the Thelon paleosol and the Thelon Formation. Within the paleosol, illite is a common component developed on altered feldspar and, interstitially, after kaolinite. In the Thelon Formation, illite is a minor component and, because of the lack of feldspathic grains, almost all of it is pseudomorphous after kaolinite. Illite crystallinity measurements suggest that illite in the paleosol is more crystalline and has a more variable octahedral structure and composition, whereas illite in the Thelon Formation is poorly crystalline and aluminous.

Chlorite is a minor component in both the paleosol and the Thelon Formation, and its texture is fibrous in both settings. Chlorite in the Thelon paleosol 
is a common component in basal samples, where it typically occurs as an alteration of protolith biotite or hornblende. In the Thelon Formation sandstone, chlorite is a minor component, occurring as an alteration on the margins of detrital biotite, and as interstitial authigenic fibres. Chlorites from the two settings could not be distinguished by means of XRD.

It is evident that the kaolinite, illite and chlorite within the Thelon paleosol cannot easily be proven to have formed during paleoweathering. Although illite is generally more poorly crystalline and more aluminous in the Thelon Formation than in the paleosol, kaolinite and chlorite within the Thelon paleosol do not appear to be chemically distinct from the same minerals within the Thelon Formation. However, subtle differences in texture, distribution and abundance exist between the two settings. These subtle differences, together with: (a) the occurrence of phyllosilicate-and hematite-altered 'basement' clasts, interpreted as paleoweathered clasts, within parts of the Thelon Formation which otherwise lack phyllosilicates and hematite; and (b) the presence of a phyllosilicate-bearing paleosol unconformably beneath quartz-cemented Thelon Formation that is devoid of phyllosilicates; all suggest that some kaolinite, chlorite and illite did develop during paleoweathering, before deposition of the Thelon Formation.

Conversely, the presence of illite pseudomorphous after vermiform kaolinite, in both the paleosol and Thelon Formation, suggests that illitization of the kaolinite 
in both settings occurred at the same time. The notion that illitization of kaolinite in the paleosol and overlying Thelon Formation are coeval may be tested by determining, using radiogenic isotopes, if illite ages in both settings are the same.

\section{CONCLUSIONS}

The preceding description and discussion of diagenetic minerals and their paragenesis within basal Thelon Formation sandstones, and of effects that Thelon Formation diagenesis has had on the underlying Thelon paleosol, lead to the following conclusions:

(1) Burial diagenesis within the Thelon Formation has resulted in grain-to-grain compaction and subsequent pressure solution, and stylolite formation.

(2) Burial diagenesis within the Thelon Formation also led, in the study area, to the formation of new minerals in the following paragenetic sequence: quartz cement $\rightarrow$ kaolinite $\rightarrow$ illite, chlorite $\rightarrow$ fluorapatite, APS $\rightarrow$ hematite. Dolomite elsewhere in the Thelon Basin formed after fluorapatite and prior to hematite.

(3) Only the kandite polytype kaolinite has been identified within the study areas. Abundant in most samples, it typically forms pore-occluding vermiform books, or, less 
commonly, as blades.

(4) Diagenetic illite within the study area is typically poorly crystalline and aluminous (commonly I.C. $\left.>.42 \Delta^{\circ} 2 \Theta, I(002) / I(001)>.4\right)$. In sandstones from the study localities, all of which are feldspar poor, illite is commonly interstitial and pseudomorphous after kaolinite.

(5) In the study localities, diagenetic chlorite is a minor component that formed either as an alteration on ferromagnesian minerals such as biotite, or as interstitial fibres with no obvious precursor mineral.

(6) Fluorapatite occurs as interstitial blocky or bladed crystals. The bladed, cementing crystals contain pitted cores with anomalous amounts of $\mathrm{C}, \mathrm{S}$ and $\mathrm{Cl}$, which suggest that a precursor sulphate mineral and/or organic carbon complex may have existed.

(7) A new occurrence of a hydrated alumino-sulphate-phosphate mineral (APS) has been established within the Thelon Formation. The composition of this mineral is intermediate between crandallite group and beudantite group minerals, and it contains A-site Ca, Sr, Ba and LREE. The APS mineral appears to have formed by local dissolution of fluorapatite (as suggested by corroded cores of bladed crystals), and kaolinite. 
(8) Geochemically, the fluids that were responsible for the formation of diagenetic minerals in the study localities started as oxidized and acidic meteoric zone fluids, became more alkaline, and then became oxidizing once more.

(9) Based on the persistence of kaolinite and poorly crystalline aluminous illite in samples of the basal Thelon Formation which were studied, the sediments appear to have remained within the diagenetic realm, and temperatures of the diagenetic fluids appear not to have exceeded $200^{\circ} \mathrm{C}$.

(10) The Thelon paleosol has been structurally and chemically altered during burial diagenesis of the overlying Thelon Formation, producing: (a) stylolites, (b) local quartz and hematite veins, (c) the APS mineral, and (d) the pervasive illitization of kaolinite.

(11) Phyllosilicates in the Thelon paleosol are commonly indistinguishable, physically and chemically, from those formed diagenetically within the Thelon Fm. 


\title{
REFERENCES
}

Al-Gailani, M.B. 1981. Authigenic mineralizations at unconformities: implication for reservoir characteristics. Sedimentary Geology, v. 29, pp. 89-115.

\begin{abstract}
Almon, W.R. and Davies, D.K. 1979. Regional diagenetic trends in the Lower Cretaceous Muddy sandstone, Powder River Basin. Society of Economic Paleontologists and Mineralogists, Special Publication 26, pp. 379-400.
\end{abstract}

Altschuler, Z.S. 1973. The weathering of phosphate deposits - geochemical and environmental aspects. In: Environmental phosphorous handbook. Eds.: E.J. Griffith, A. Beeton, J.M. Spencer and D.T. Mitchell. John Wiley and Sons, pp. 33-96.

Altschuler, Z.S., Jaffe, E.R. and Cuttitta, F. 1956. The aluminum phosphate zone of the Bone Valley Formation, Florida, and its uranium deposits. United States Geological Survey, Professional Paper 300, pp. 495-504.

Bailey, S.W. 1980. Structures of layer silicates. In: Crystal structures of clay minerals and their X-ray identification. Eds.: G.W. Brindley and G. Brown. Mineralogical Society, London, pp. 1-123.

Banfield, J.F. and Eggleton, R.A. 1989. Apatite replacement and rare earth 
mobilization, fractionation, and fixation during weathering. Clays and Clay Minerals, v. 37 , pp. $113-127$.

Baturin, G.N. 1982. Phosphorites on the sea floor, origin, composition and distribution. Developments in Sedimentology 33, 343 p.

Bentor, Y.K. 1980. Marine phosphorites - geochemistry, occurrence, genesis. Society of Economic Paleontologists and Mineralogists, Special Publication 29, 249 p.

Bethke, C.M. and Marshak, S. 1990. Brine migration across North America - the plate tectonics of groundwater. Annual Reviews of Earth and Planetary Sciences, v. 18, pp. $287-315$.

Blatt, H. 1979. Diagenetic processes in sandstones. Society of Economic Paleontologists and Mineralogists, Special Publication 26, pp. 141-157.

Blatt, H., Middleton, G.V., and Murray, R.C. 1980. Origin of sedimentary rocks. Prentice-Hall, 634 p.

Blount, A.M. 1974. The crystal structure of crandallite. American Mineralogist, v. 59, pp. $41-47$. 
Botinelly, T. 1976. A review of the minerals of the alunite-jarosite, beudantite, and plumbogummite groups. United States Geological Survey Journal of Research, v. 4, pp. 213-216.

Bucke, D.P. and Mankin, C.J. 1971. Clay-mineral diagenesis within interlaminated shales and sandstones. Journal of Sedimentary Petrology, v. 41, pp. 971-981.

Burkov, V.V. and Podporina, Ye.K., 1967. Rare earths in granitoid residuum. Doklady Akademi Nauk SSSR, v. 177, pp. 691-694.

Burley, S.D, Kantorowicz, J.D. and Waugh, B. 1985. Clastic diagenesis. In: Sedimentology recent developments and applied aspects. Eds: P.J. Brenchley and B.P.J. Williams. The Geological Society, Blackwell Scientific Publications, pp. 189226.

Burnett, W.C. and Riggs, S.R. 1986. Phosphate deposits of the world. Volume 3, Neogene to Modern phosphorites. Cambridge University Press, 464 p.

Cecile, M.P. 1973. Lithofacies analysis of the Proterozoic Thelon Formation, Northwest Territories. M.Sc. thesis, Carleton University, Ottawa, 119 p.

Cook, P.J. 1984. Spatial and temporal controls on the formation of phosphate 
deposits - a review. In: Phosphate minerals. Eds.: J.O. Nriagu and P.B. Moore. Springer-Verlag, pp. 242-274.

Dahanayake, K. and Subasinghe, S.M.N.D. 1989. A modern terrestrial phosphorite an example from Sri Lanka. Sedimentary Geology, v. 61, pp. 311-316.

Davies, D.K., Almon, W.R., Bonis, S.B. and Hunter, B.E. 1979. Deposition and diagenesis of Tertiary-Holocene volcaniclastics, Guatemala. Society of Economic Paleontologists and Mineralogists, Special Publication 26, pp. 281-306.

Dean, R.S. 1967. Mineralogical examination of sandstone and siltstone, Thelon Formation (Proterozoic), Northwest Territories. Department of Energy, Mines and Resources, Mines Branch Investigation Report, IR 67-28, 7 p.

Donaldson, J.A. 1969. Descriptive notes (with particular reference to the late Proterozoic Dubawnt Group) to accompany a geological map of central Thelon plain, Districts of Keewatin and Mackenzie (65M, NW1/2, 66B, C, D, 75P E1/2, 76A E1/2). Geological Survey of Canada, Paper 68-49, 4 p.

Duddy, I.R. 1980. Redistribution and fractionation of rare-earth and other elements in a weathering profile. Chemical Geology, v. 30, pp. 363-381. 
Duffin, M.E., Lee, M., Klein, G.deV. and Hay, R.L. 1989. Potassic diagenesis of Cambrian sandstones and Precambrian granitic basement in UPH-3 deep hole, upper Mississippi Valley, U.S.A. Journal of Sedimentary Petrology, v. 59, pp. 848-861.

Dunoyer De Segonzac, G. 1970. The transformation of clay minerals during diagenesis and low-grade metamorphism: a review. Sedimentology, 15, pp. 281-346.

Eriksson, K.A. and Soegaard, K. 1985. The petrography and geochemistry of Archean and early Proterozoic sediments: implications for crustal compositions and surface processes. Geological Survey of Finland, Bulletin 331, pp. 8-32.

Eslinger, E.V. and Huff, G. 1987. Clay minerals in reservoir rock of the Cano Limon oil field, Llanos Basin, Colombia. Clay Minerals Society, $24^{\text {th }}$ Annual Meeting Abstracts, p. 53.

Eslinger, E.V. and Pevear, D. 1988. Clay minerals for petroleum geologists and engineers. Society of Economic Paleontologists and Mineralogists, Short Course Notes, No. 22, 6-1 to 6-29.

Espenshade, G.H. and Spencer, C.W. 1963. Geology of phosphate deposits of northern peninsular Florida. United States Geological Survey, Bulletin 1118, 115 p. 
Esquevin, J. 1969. Influence de la composition chimique des illites sur leur cristallinité. Bulletin du Centre de Recherches de Pau - SNPA, v. 3, pp. 147-153.

Fleet, A.J. 1984. Aqueous and sedimentary geochemistry of the rare earth elements. In: Rare earth element geochemistry. Ed.: P. Henderson. Developments in Geochemistry 2, Elsevier, pp. 343-373.

Flicoteaux, R. and Lucas, J. 1984. Weathering of phosphate minerals. In: Phosphate minerals. Eds.: J.O. Nriagu and P.B. Moore. Springer-Verlag, pp. 292-317.

Frey, M. 1987. Very low-grade metamorphism of clastic sedimentary rocks. In: Low temperature metamorphism. Ed.: M. Frey. Blackie, pp. 9-58.

Füchtbauer, H. 1974. Zur diagenese fluviatiler sandsteine. Geologisce Rundschau, v. 63 , pp. $904-925$.

Gall, Q. 1992. Precambrian paleosols in Canada. Canadian Journal of Earth Sciences, v. 29 , pp. $2530-2536$.

Gall, Q. and Hiscott, R.N. 1986. Diagenesis of locally uraniferous sandstones of the Deer Lake Group, and sandstones of the Howley Formation, Carboniferous Deer Lake subbasin, western Newfoundland. Bulletin of Canadian Petroleum Geology, v. 
34, pp. 17-29.

Gall, Q., Peterson, T.D. and Donaldson, J.A. 1992. A proposed revision of early Proterozoic stratigraphy of the Thelon and Baker Lake basins, Northwest Territories. Geological Survey of Canada, Paper 92-1C, pp. 129-137.

Garrels, R.M. and Christ, C.L. 1965. Solutions, minerals and equilibria. Harper and Row, 450 p.

Girard, J.-P., Deynoux, M. and Nahon, D. 1989. Diagenesis of the Upper Proterozoic siliciclastic sediments of the Taoudeni Basin (west Africa) and relation to diabase emplacement. Journal of Sedimentary Petrology, v. 59, pp. 233-248.

Girard, J.-P. and Deynoux, M. 1991. Oxygen isotope study of diagenetic quartz overgrowths from the Upper Proterozoic quartzites of western Mali, Taoudeni Basin: implications for conditions of quartz cementation. Journal of Sedimentary Petrology, v. 61 , pp. $406-418$.

Golterman, H.L. 1973. Vertical movement of phosphate in freshwater. In: Environmental phosphorous handbook. Eds.: E.J. Griffith, A. Beeton, J.M. Spencer and D.T. Mitchell. John-Wiley and Sons, pp. 509-538. 
Grim, R.E., Bray, R.H. and Bradley, W.F. 1937. The mica in argillaceous sediments. American Mineralogist, v. 22, pp. 813-829.

Hancock, N.J. and Taylor, A.M. 1978. Clay mineral diagenesis and oil migration in the Middle Jurassic Brent Sand Formation. Journal of the Geological Society of London, v. 135, pp. 69-72.

Hanor, J.S. 1979. The sedimentary genesis of hydrothermal fluids. In: Geochemistry of hydrothermal ore deposits. Ed.: H.L. Barnes. Wiley-Interscience, pp. 137-172.

Harper, D.A., Longstaffe, F.J., Wadleigh, M.A., Carter, T.R. and Easton, R.M. 1991. Potassic alteration of Precambrian basement rocks in southwestern Ontario. Geological Association of Canada-Mineralogical Association of Canada-Society of Economic Geologists Annual Meeting, Program with Abstracts, v., p. A51.

Haynes, F.M. 1988. Fluid-inclusion evidence of basinal brines in Archean basement, Thunder Bay Pb-Zn-Ba district, Ontario, Canada. Canadian Journal of Earth Science, v. 25 , pp. 1884-1894.

Heald, M.T. and Larese, R.E. 1974. Influence of coatings on quartz cementation. Journal of Sedimentary Petrology, v. 44, pp. 1269-1274. 
Heling, D. 1974. Diagenetic alteration in argillaceous sediments in the Rhine-graben (SW Germany). Sedimentology, v. 21, pp. 463-472.

Herrmann, A.G. 1978. Yttrium and lanthanides. In: Handbook of geochemistry, Vol. II-5. Ed.: K.W. Wedepohl. Springer-Verlag, pp. 57-71-A to 57-71-O.

Hoeve, J., Rawsthorne, K. and Quirt, D. 1981. Uranium metallogenic studies: clay mineral stratigraphy and diagenesis in the Athabasca Group. Saskatchewan Geological Survey, Miscellaneous Report 81-4, pp. 76-89.

Hower, J., Eslinger, E., Hower, M.E. and Perry, E.A. 1976. Mechanism of burial metamorphism of argillaceous sediments: 1. Mineralogical and chemical evidence. Geological Society of America Bulletin, v. 87, pp. 725-737.

Hurst, A. and Irwin, H. 1982. Geological modelling of clay diagenesis in sandstones. Clay Minerals, v. 17, pp. 5-22.

Hurst, V.J. and Kunkle, A.C. 1985. Dehydroxylation, rehydroxylation, and stability of kaolinite. Clays and Clay Minerals, v. 33, pp. 1-14.

Hutcheon, I., Oldershaw, A. and Ghent, E.D. 1980. Diagenesis of Cretaceous sandstones of the Kootenay Formation at Elk Valley (southeastern British Columbia) 
and Mt Allan (southwestern Alberta). Geochimica et Cosmochimica Acta, v. 44 pp. $1425-1435$.

Keller, W.D. 1970. Environmental aspects of clay minerals. Journal of Sedimentary Petrology, v. 40, pp. 788-813.

Kisch, H.J. 1983. Mineralogy and petrology of burial diagenesis (burial metamorphism) and incipient metamorphism in clastic rocks. In: Diagenesis in sediments and sedimentary rocks, 2. Eds.: G. Larsen and G.V. Chilingar. Developments in Sedimentology, Elsevier, v. 25B, pp. 289-493.

1987. Correlation between indicators of very-low grade metamorphism. In: Low temperature metamorphism. Ed.: M. Frey. Blackie, pp. 227-300.

1990. Calibration of the anchizone: a critical comparison of illite 'crystallinity' scales used for definition. Journal of Metamorphic Geology, v. 8, pp. 31-46.

Kodama, H. 1985. Infrared spectra of minerals. Reference guide to identification and characterization of minerals for the study of soils. Agriculture Canada, Technical Bulletin 1985-1E, 198 p.

Kotzer, T.G., Kyser, T.K. and Irving, E. 1992. Paleomagnetism and the evolution of 


$$
3-1-45
$$

fluids in the Proterozoic Athabasca Basin, northern Saskatchewan, Canada. Canadian Journal of Earth Sciences, v. 29, pp. 1474-1491.

Krauskopf, K.B. 1956. Dissolution and precipitation of silica at low temperatures. Geochimica et Cosmochimica Acta, v. 10, pp. 1-26.

Kubler, B. 1967. Anchimétamorphisme et schistosité. Bulletin du Centre de Recherches de Pau - SNPA, v. 1, pp. 259-278.

Lander, R.H., Bloch, S., Mehta, S. and Atkinson, C.D. 1992. Burial diagenesis in the giant Yacheng gas field, Peoples Republic of China: bearing on illite reaction pathways. Journal of Sedimentary Petrology, v. 61, pp. 256-268.

Lefebvre, J.-J. and Gasparrini, C. 1980. Florencite, an occurrence in the Zairian copperbelt. Canadian Mineralogist, v. 18, pp. 301-311.

Lidial, E.G. and Ceci, V.M. 1991. Authigenic K-feldspar in the Precambrian basement of Ohio and its effect on tectonic discrimination of granitic rocks. Canadian Journal of Earth Sciences, v. 28, pp. 1624-1634.

Lindsay, W.L. 1979. Chemical equilibria in soil. John-Wiley and Sons, 449 p. 
Love, J.D. 1964. Uraniferous phosphatic lake beds of Eocene age in intermontane basins of Wyoming and Utah. United States Geological Survey, Professional Paper 474-E, 66 p.

Mackenzie, F.T. and Garrels, R.M. 1966. Silica-bicarbonate balance in the ocean and early diagenesis. Journal of Sedimentary Petrology, v. 36, pp. 1075-1084.

Maxwell, D.T. and Hower, J. 1967. High-grade diagenesis and low-grade metamorphism of illite in the Precambrian Belt Series. American Mineralogist, v. 52, pp. 843-857.

Maynard, J.B. 1975. Kinetics of silica sorption by kaolinite with application to seawater chemistry. American Journal of Science, v. 275, pp. 1028-1048.

McKelvey, V.E. 1973. Abundance and distribution of phosphorous in the lithosphere. In: Environmental phosphorous handbook. Eds.: E.J. Griffith, A. Beeton, J.M. Spencer and D.T. Mitchell. John-Wiley and Sons, pp. 13-31.

McKie, D. 1962. Goyazite and florencite from two African carbonatites. Mineralogical Magazine, v. 33, pp. 281-297.

Mensing, T.M. and Faure, G. 1983. Identification and age of neoformed Paleozoic 
feldspar (adularia) in a Precambrian basement core from Scioto County, Ohio, USA. Contributions to Mineralogy and Petrology, v. 82, pp. 327-333.

Miller, A.R. 1983. A progress report: uranium-phosphorous association in the Helikian Thelon Formation and sub-Thelon saprolite, central District of Keewatin. Geological Survey of Canada, Paper 83-1A, pp. 449-456.

Miller, A.R., Cumming, G.L. and Krstic, D. 1989. U-Pb, Pb-Pb, and K-Ar isotopic study and petrography of uraniferous phosphate-bearing rocks in the Thelon Formation, Dubawnt Group, Northwest Territories, Canada. Canadian Journal of Earth Sciences, v. 26, pp. 867-880.

Millot, G. 1970. Geology of clays: weathering, sedimentology, geochemistry. SpringerVerlag, 429 p.

Munro, K.A. 1984. Possible regolith beneath Proterozoic sandstone of the Thelon Formation, Northwest Territories. M.Sc. thesis, Carleton University, Ottawa, 44 p.

Nagelschmidt, G. 1937. X-ray investigation on clays. Zeitschrift Für Kristallographie, v. 97 , pp. 514-521.

Nesbitt, H.W. 1979. Mobility and fractionation of rare earth elements during 
weathering of a granodiorite. Nature, v. 279, pp. 206-210.

Nesbitt, H.W. and Young, G.M. 1989. Formation and diagenesis of weathering profiles. Journal of Geology, v. 97, pp. 129-147.

Newnham, R.E. 1961. A refinement of the dickite structure and some remarks on polymorphism in kaolin minerals. Mineralogical Magazine, v. 32, pp. 683-704.

Nriagu, J.O. 1976. Phosphate-clay mineral reactions in soils and sediments. Canadian Journal of Earth Sciences, v. 13, pp. 717-736.

Overton, A. 1971. Seismic survey of Dubawnt Group. Geological Survey of Canada, Paper 71-1A, p. 58.

Pagel, M., Poty, B. and Sheppard, S.M.F. 1980. Contributions to some Saskatchewan uranium deposits mainly from fluid inclusions and isotopic data. In: Uranium in the Pine Creek geosyncline. Eds.: S. Ferguson and A.B. Goleby. International Atomic Energy Agency, Vienna, pp. 639-654.

Peterson, T.D. 1992. Early Proterozoic ultrapotassic volcanism of the Keewatin hinterland, Canada. In: Vol. 1. Kimberlites, related rocks and mantle xenoliths. Eds.: H.O.A. Meyer and O.H. Leonardos. Proceedings 5th International Kimberlite 
Conference, pp. 221-235.

Pittman, E.D. 1972. Diagenesis of quartz in sandstones as revealed by scanning electron microscopy. Journal of Sedimentary Petrology, v. 42, pp. 507-519.

Reynolds, R.C. 1963. Potassium-rubidium ratios and polymorphism in illites and microclines from the clay-size fraction of Proterozoic carbonate rocks. Geochimica et Cosmochimica Acta, v. 27, pp. 1097-1112.

Robin, P.-Y.F. 1978. Pressure solution at grain-to-grain contacts. Geochimica et Cosmochimica Acta, v. 42, pp. 1383-1389.

Ross, G. 1983. Sedimentology photo. Journal of Sedimentary Petrology, v. 53, p. 894.

Russell, R.T. and Trueman, N.A. 1971. The geology of the Duchess phosphate deposits, northwestern Queensland, Australia. Economic Geology, v. 66, pp. 11861214.

Scott, K.M. 1987. Solid solution in, and classification of, gossan-derived members of the alunite-jarosite family, northwest Queensland, Australia. American Mineraiogist, v. 72 , pp. $178-187$. 
Sholkovitz, E.R. 1989. Artifacts associated with the chemical leaching of sediments for rare-earth elements. Chemical Geology, v. 77, pp. 47-51.

Stoffregen, R.E. and Alpers, C.N. 1987. Woodhouseite and svanbergite in hydrothermal ore deposits: products of apatite destruction during advanced argillic alteration. Canadian Mineralogist, v. 25, pp. 201-211.

Swirydczuk, K., Wilkinson, B.H. and Smith, G.R. 1981. Synsedimentary lacustrine phosphorites from the Pliocene Glenns Ferry Formation of southwestern Idaho. Journal of Sedimentary Petrology, v. 51, pp. 1205-1214.

Spötl, C. 1990. Authigenic aluminum phosphate-sulphates in sandstones of the Mitterberg Formation, northern Calcareous Alps, Austria. Sedimentology, v. 37, pp. 837-845.

Surdam, R.C., Dunn, T.L., Heasler, H.P. and MacGowan, D.B. 1989. Porosity evolution in sandstone/shale systems. In: Burial diagenesis. Ed.: I.E. Hutcheon. Mineralogical Association of Canada, Short Course, v. 15, pp. 61-134.

Taylor, J.M. 1950. Pore-space reduction in sandstones. Bulletin of the American Association of Petroleum Geologists, v. 34, pp. 701-716. 
Thiry, M. and Millot, G. 1987. Mineralogical forms of silica and their sequence of formation in silcretes. Journal of Sedimentary Petrology, v. 57, pp. 343-352.

Trueman, N.A. 1965. The phosphate, volcanic and carbonate rocks of Christmas Island (Indian Ocean). Journal of the Geological Society of Australia, v. 12, pp. 261283.

Trurnit, P. 1968. Pressure solution phenomena in detrital rocks. Sedimentary Geology, v. 2, pp. 89-114.

Turner, P. 1980. Continental red beds. Developments in Sedimentology 29. Elsevier Scientific Publishing Company, 562 p.

Velbel, M.A. 1985. Basement alteration at unconformities. Geological Society of America $98^{\text {th }}$ Annual Meeting, Abstracts with Programs, p. 740.

Velde, B. 1965. Experimental determination of muscovite polymorph stabilities. American Mineralogist, v. 50, pp.436-449.

Velde, B. and Hower, J. 1963. Petrologic significance of illite polymorphism in Paleozoic sedimentary rocks. American Mineralogist, v. 48, pp. 1239-1254. 
Vieillard, P., Tardy, Y. and Nahon, D. 1979. Stability fields of clays and aluminum phosphates: paragenesis in lateritic weathering of argillaceous phosphatic sediments. American Mineralogist, v. 64, pp. 626-634.

Walker, T.R. 1967a. Formation of red beds in modern and ancient deserts. Geological Society of America Bulletin, v. 78, pp. 353-368.

------ 1967b. Color of recent sediments in tropical Mexico: a contribution to the origin of red beds. Geological Society of America Bulletin, v. 78, pp. 917-920.

Wilson, J.A. 1985a. Crandallite group minerals in the Helikian Athabasca Group in Alberta, Canada. Canadian Journal of Earth Sciences, v. 22, pp. 637-641.

------- 1985b. Geology of the Athabasca Group in Alberta. Alberta Geological Survey, Bulletin 49, 47 p.

Wright, V.P. 1992. Paleosol recognition: a guide to early diagenesis in terrestrial settings. In: Diagenesis, III. Eds.: K.H. Wolf and G.V. Chilingarian. Developments in Sedimentology 47, pp. 591-619.

Young, E.J. 1958. An occurrence of gorceixite in Arkansas. The American Mineralogist, v. 43, pp. 762-765. 
Zanin, Yu.N. 1968. Zones of lateritic weathering of secondary phosphorites of AltaySayan region. International Geology Reviews, v. 10, pp. 1119-1127. 


\section{FIGURE CAPTIONS}

Fig. 3.1.1 Dust rims between detrital grains (small arrows) and quartz overgrowths (O). Note impinging grain-to-grain contacts (large arrows). $1.0 \mathrm{~mm}$ bar scale.

Fig. 3.1.2 Detrital grains $(G)$ surrounded by (in order of formation) dust rims (arrows), quartz overgrowths (O), and occluding chert cement (C). $0.125 \mathrm{~mm}$ bar scale.

Fig. 3.1.3 Embayed quartz overgrowths and grain boundaries (arrows), chert cement (C) and vermicular kaolinite $(\mathrm{K}) .0 .5 \mathrm{~mm}$ bar scale.

Fig. 3.1.4 Laminae of fascicular chalcedony (C), separated by hematite laminae (H), line a pore within sandstone. The pore is occluded by megaquartz (Q). The quartz cement is cut by bladed kaolinite (K), which in turn is cut by fluorapatite (A) and hematite cement $(\mathrm{H} 1) .0 .5 \mathrm{~mm}$ bar scale.

Fig. 3.1.5 Vermiform kaolinite books (K) that have grown on a feldspar grain $(\mathrm{G})$ along an indistinct boundary. $0.05 \mathrm{~mm}$ bar scale.

Fig. 3.1.6 Infrared absorption spectrum for a Profile 2 paleosol sample (DF-5), including enlargement of the characteristic hydroxyl group absorption spectrum for 
kaolinite.

Fig. 3.1.7 Infrared absorption spectrum for a Profile 2 Thelon Fm. sandstone sample (DF-1), including enlargement of the characteristic hydroxyl group absorption spectrum for kaolinite.

Fig. 3.1.8 Porosity that has been occluded by: chert (C), microquartz (M) and finally, kaolinite (K). $0.5 \mathrm{~mm}$ bar scale.

Fig. 3.1.9 Porosity occluded by tabular, twinned kaolinite $(K)$, which has a similar relationship to microquartz $(\mathrm{M})$ and chert $(\mathrm{C})$ as in Fig. 3.1.8. $0.5 \mathrm{~mm}$ bar scale.

Fig. 3.1.10 Illite (I) pseudomorphous after kaolinite, and kaolinite (K) surrounded by chert cement $(\mathrm{C}) .0 .25 \mathrm{~mm}$ bar scale.

Fig. 3.1.11 Illite fibres (I) have grown on feldspar grains within a granitoid rock fragment. $0.5 \mathrm{~mm}$ bar scale.

Fig. 3.1.12 Illite crystallinity (I.C.) vs. I(002)/I(001) plot for Profile 3 samples. Drill core depth (metres) in parentheses beside each sample point.

Fig. 3.1.13 Illite crystallinity (I.C.) vs. I(002)/I(001) plot for Profile 4 samples. Drill 


$$
3-1-56
$$

core depth, in feet, in parentheses beside sample point.

Fig. 3.1.14 Interstitial blocky fluorapatite cement (A) partly masked by opaque hematite cement $(\mathrm{H}) .0 .5 \mathrm{~mm}$ bar scale.

Fig. 3.1.15 Interstitial bladed fluorapatite cement (A) that cuts kaolinite (K), in turn has been cut by opaque hematite cement $(\mathrm{H})$. Note altered cores of fluorapatite blades (arrows). $0.25 \mathrm{~mm}$ bar scale.

Fig. 3.1.16 Backscatter scanning electron photomicrograph of intergrown bladed fluorapatite crystals displaying euhedral pits along their cores (arrows).

Fig. 3.1.17 Examples of energy dispersive spectra of bladed fluorapatite core and rim.

Fig. 3.1.18 Euhedral APS crystals (high relief, square outlines) that have grown on interstitial phyllosilicates (P) and along grain margins (arrows), are cut by hematite cement $(\mathrm{H}) .0 .05 \mathrm{~mm}$ bar scale.

Fig. 3.1.19 Euhedral APS crystals that have grown on interstitial illitized kaolinite (I) and along grain margins (arrows), are cut by hematite cement $(\mathrm{H}) .0 .2 \mathrm{~mm}$ bar scale. 
Fig. 3.1.20 Example of EDX spectrum of the rim of an APS crystal from a Profile 4 Thelon Fm. sandstone sample (QB2-175).

Fig. 3.1.21 Backscatter scanning electron photomicrograph of zoned APS crystals. Note that the APS crystals have grown on books of kaolinite (K).

Fig. 3.1.22 Energy dispersive line scan spectra of a zoned APS crystal (inset, with traverse line indicated).

Fig. 3.1.23 Lower part of an alunite (not shown) - goyazite - crandallite ternary diagram, depicting the variation in APS crystal composition.

Fig. 3.1.24 Opaque hematite $(\mathrm{H})$ both cementing and replacing detrital grains, and masking other interstitial minerals. $0.5 \mathrm{~mm}$ bar scale.

Fig. 3.1.25 Intergrown blades of opaque hematite, within both matrix and grains. 0.7 $\mathrm{mm}$ bar scale.

Fig. 3.1.26 Composite sequence of mineral paragenesis during development of the Thelon paleosol (paleoweathering), and Thelon Formation diagenesis. Dashed dividing line occurs opposite paleosol phyllosilicates for which the effects of diagenetic overprinting are uncertain. 'Time' indicates the relative order of mineral 
$3-1-58$

development. 

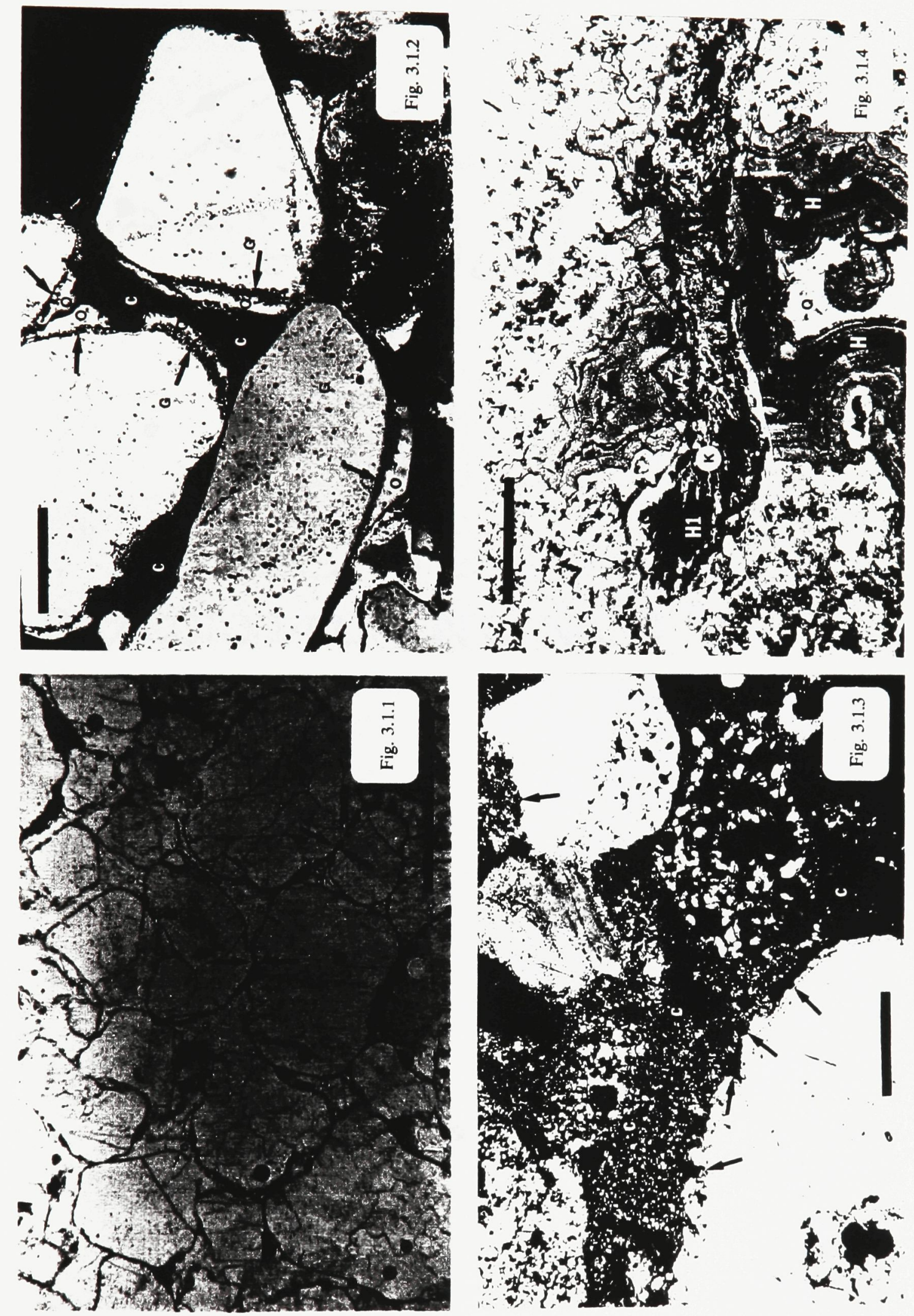

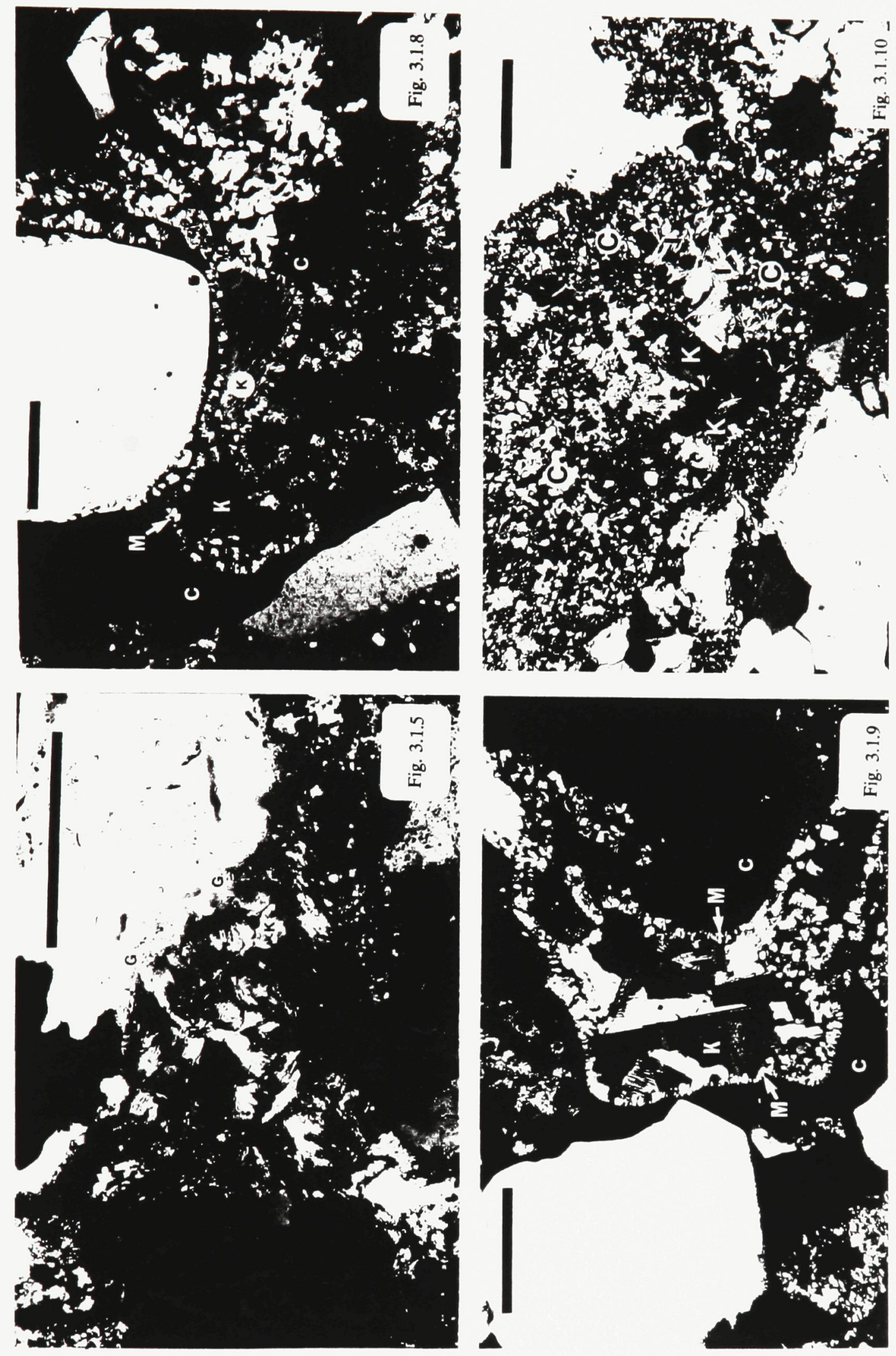

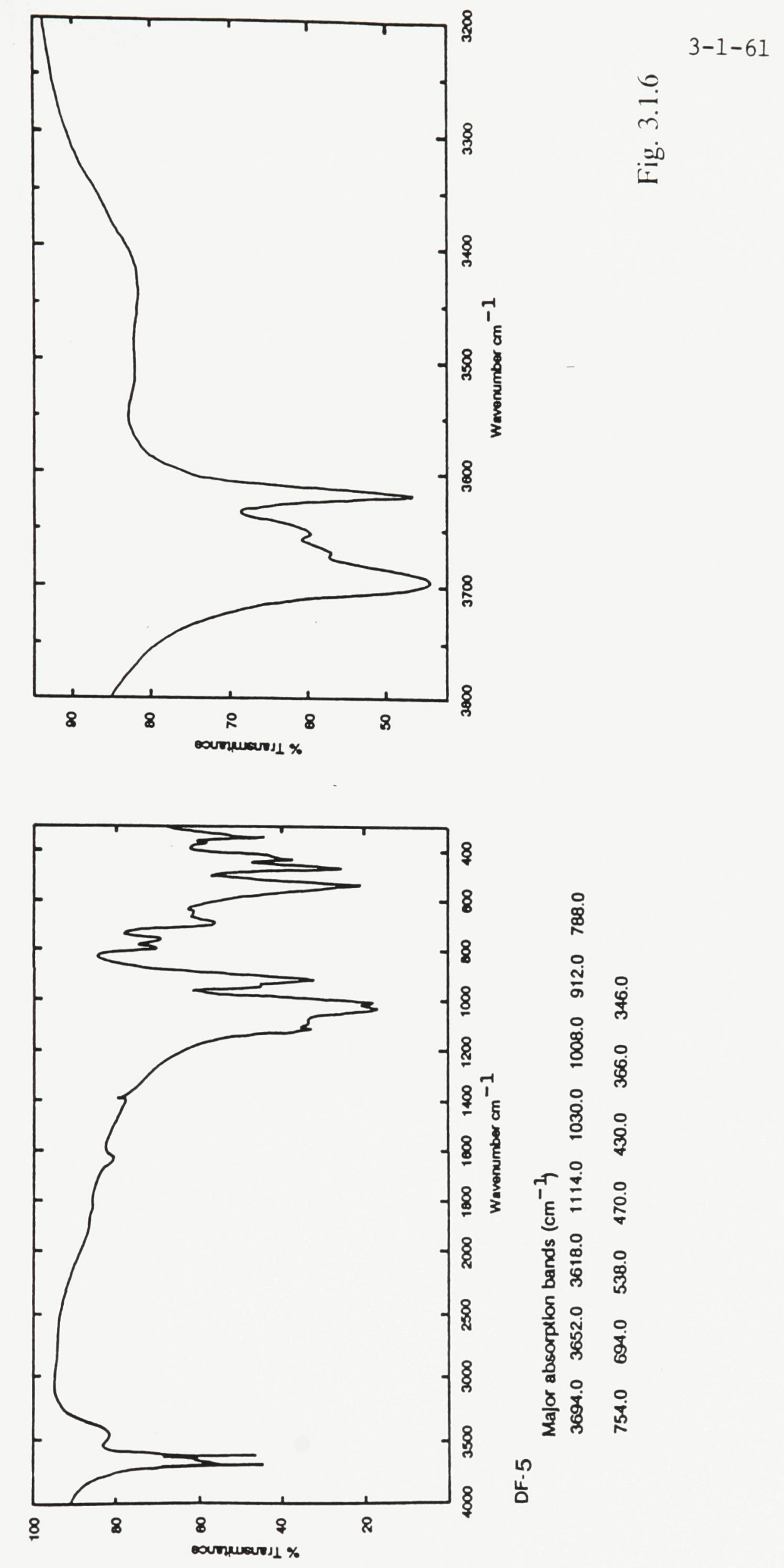

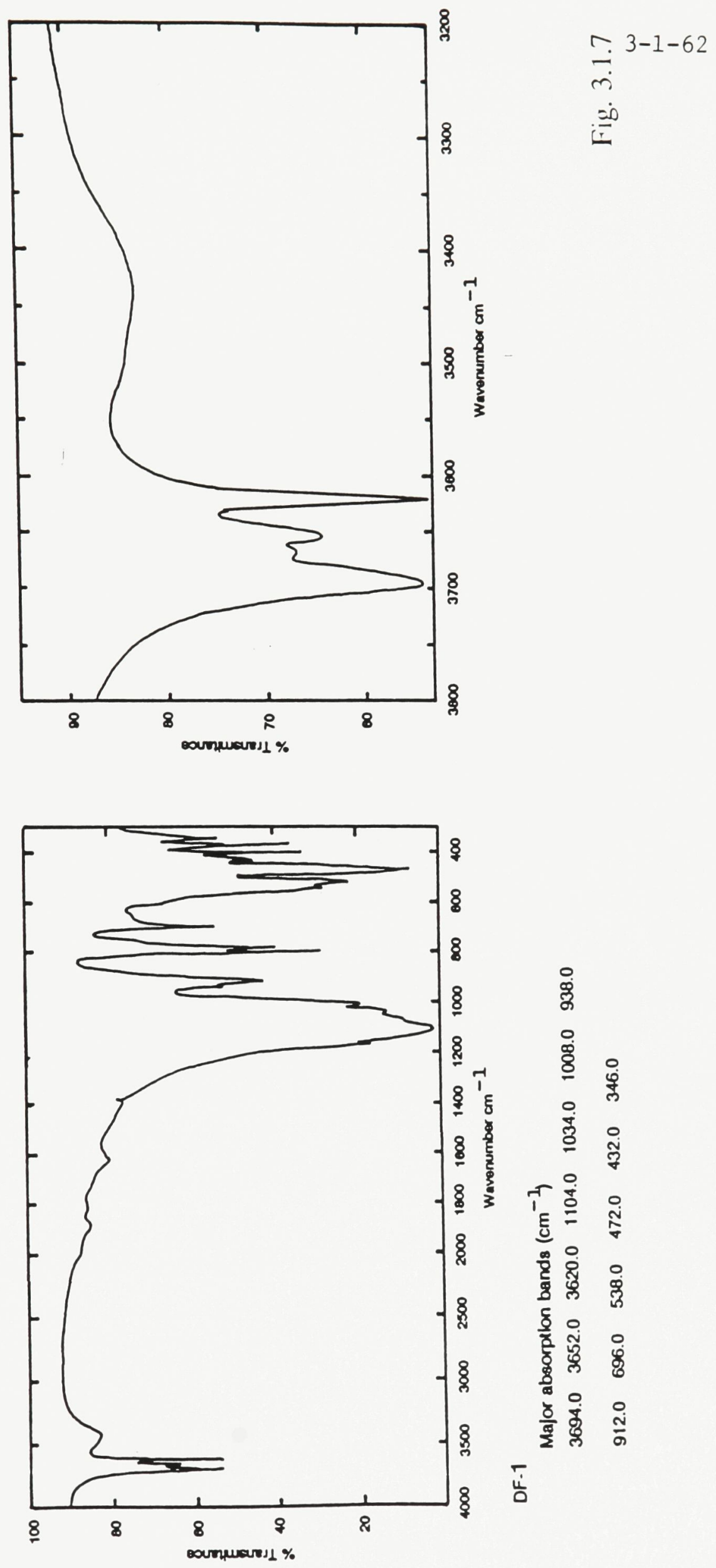


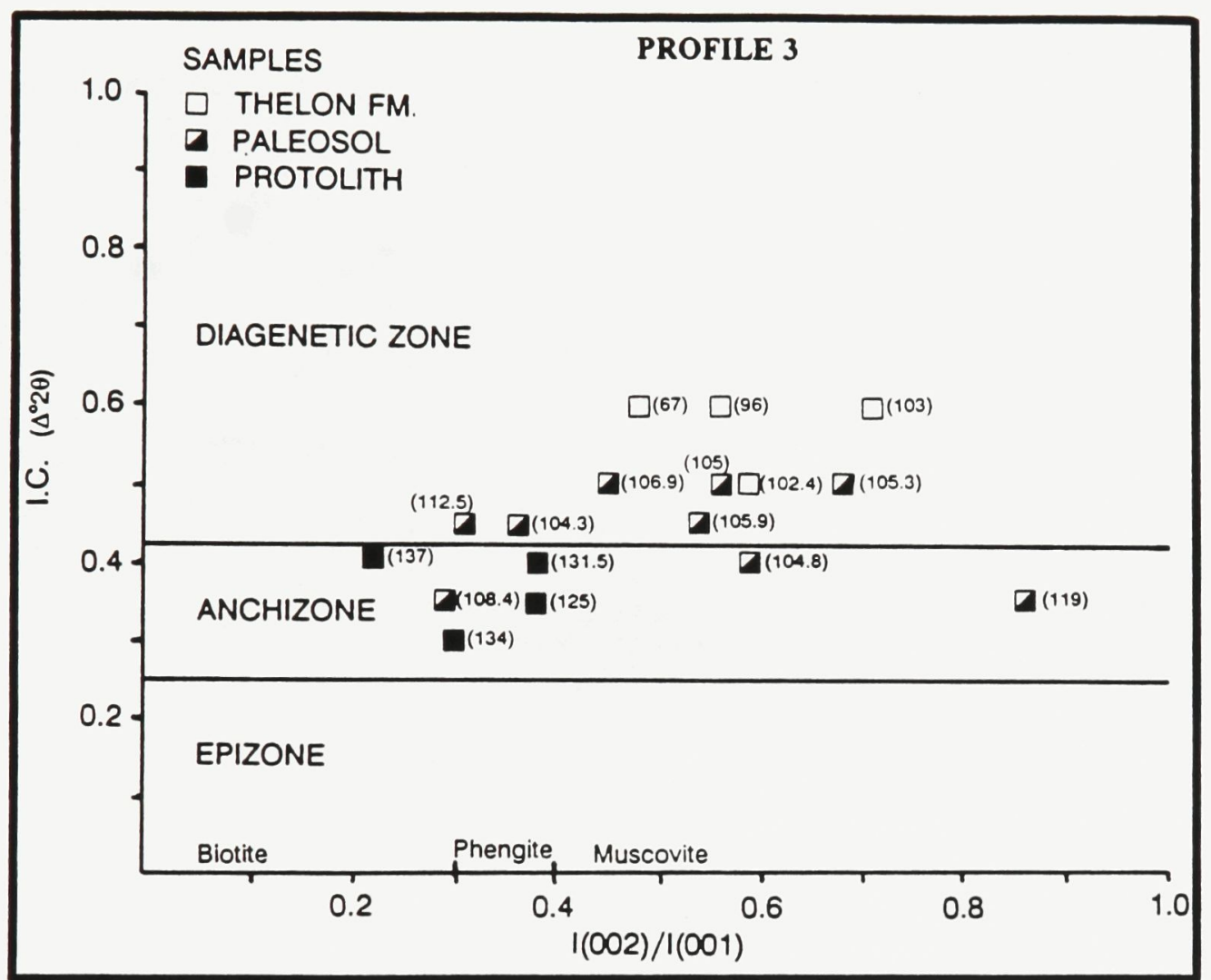

Fig. 3.1.12 


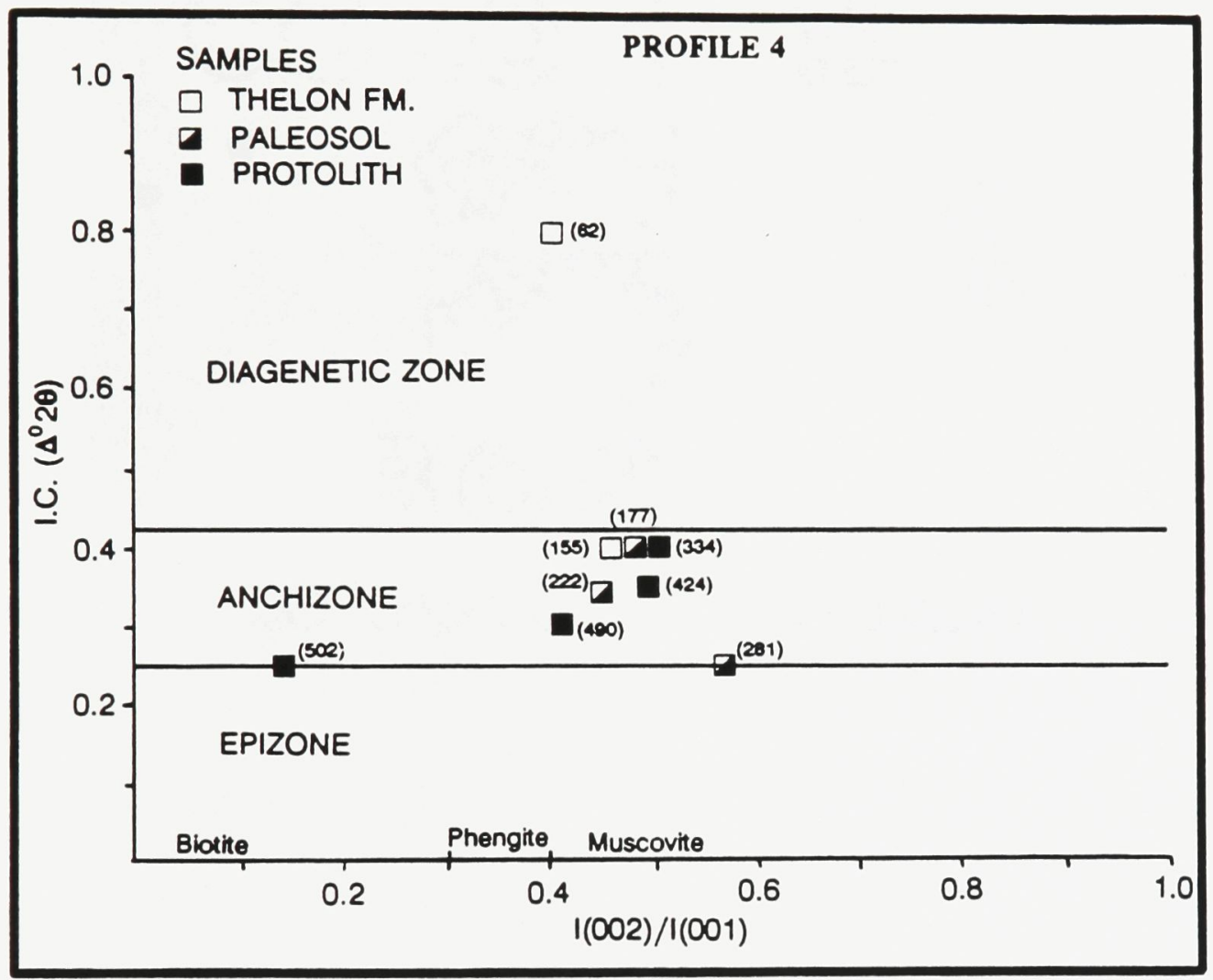

Fig. 3.1.13 

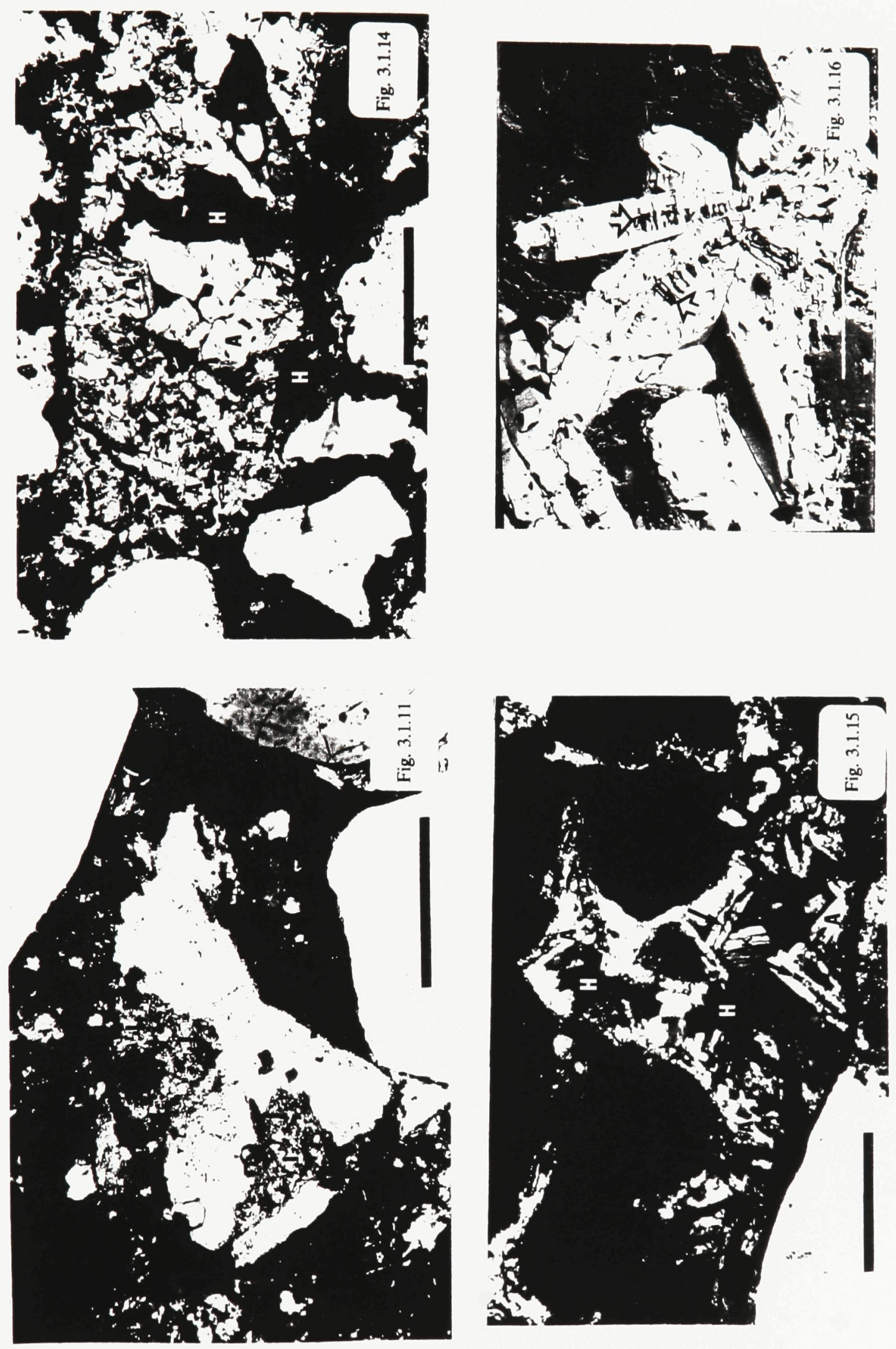


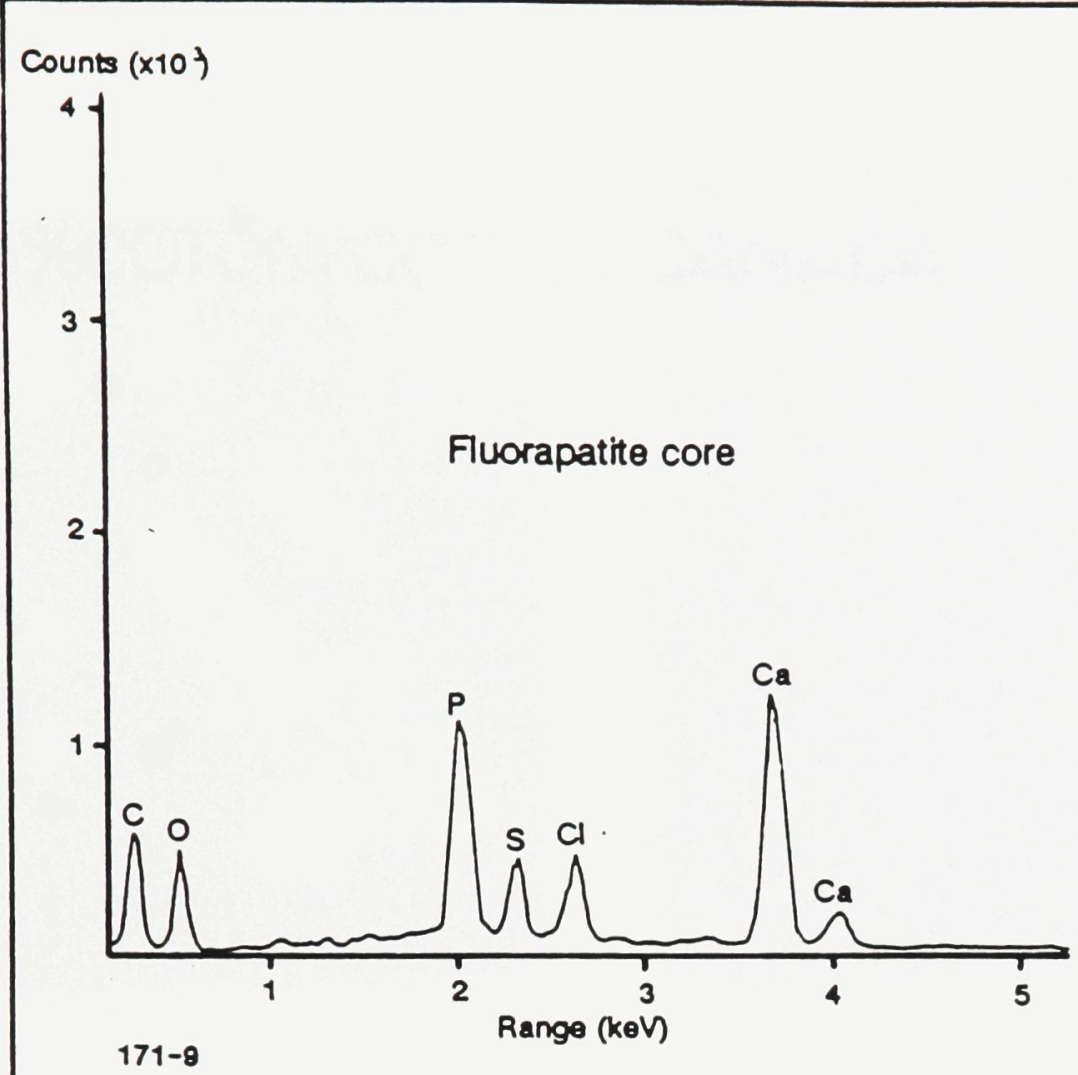

Counts $(\times 10\}$

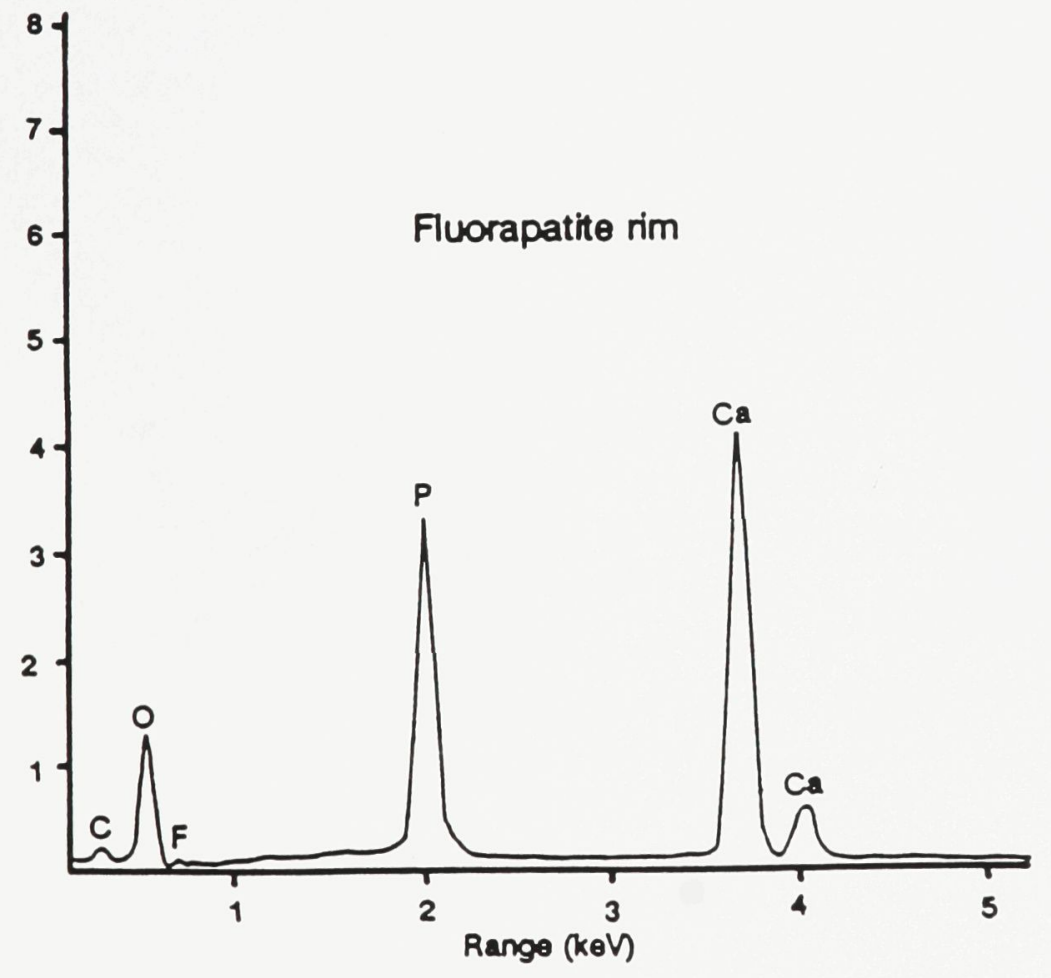

171-9

Fig. 3.1.17 

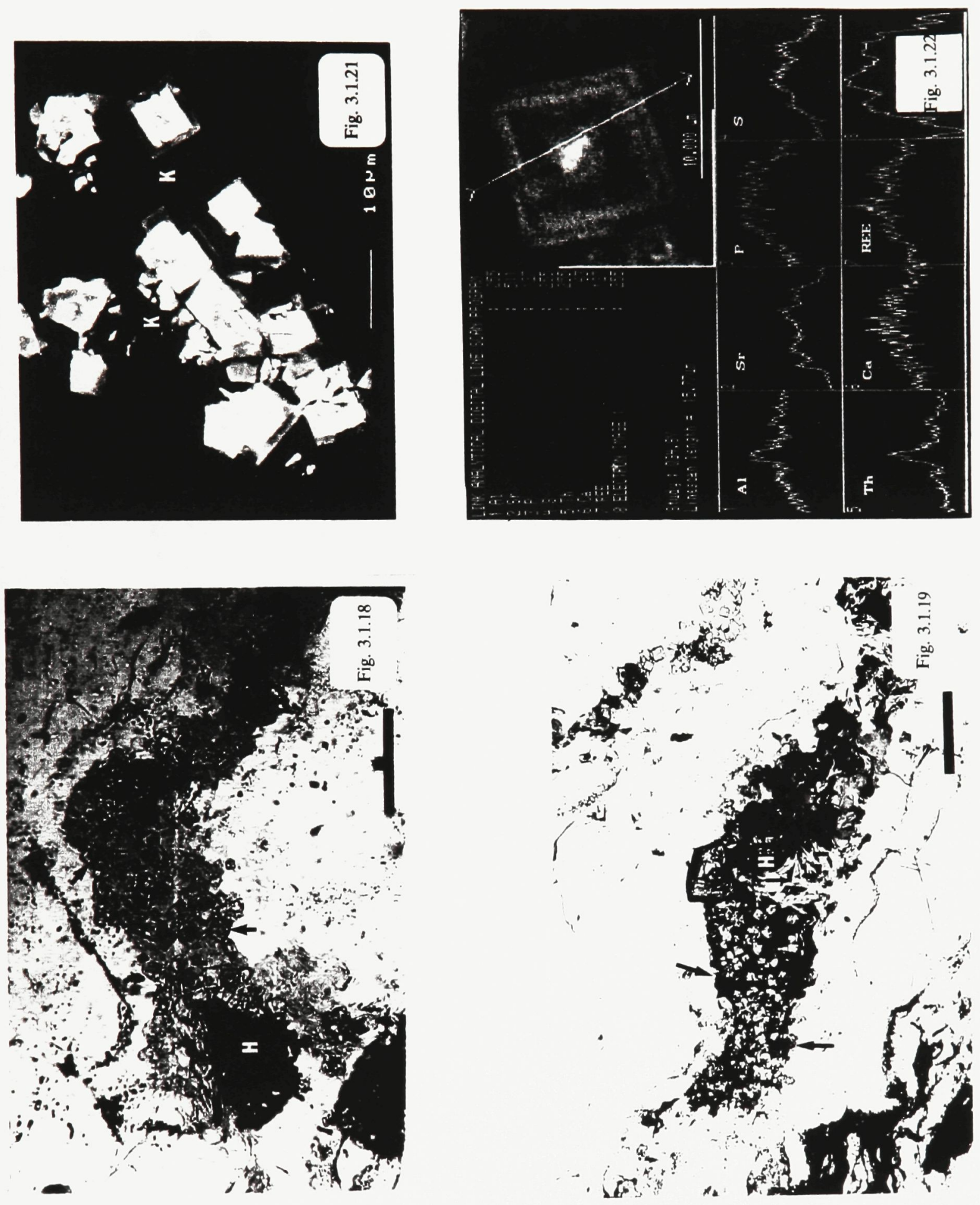
$3-1-68$

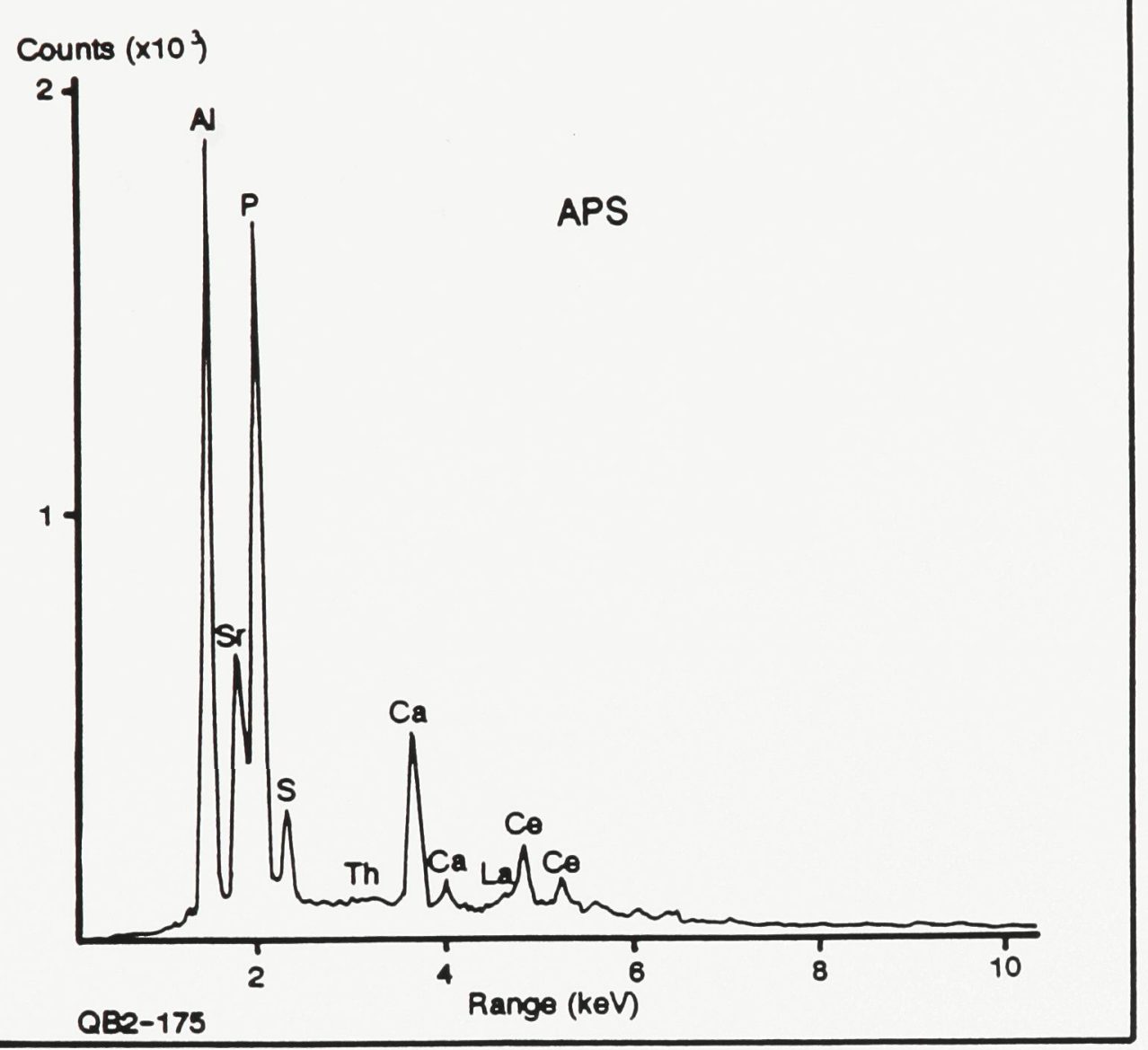

Fig. 3.1.20 
- CORE

- INTERMEDIATE

- RIM

WOODHOUSEITE

SVANBERGITE

$\mathrm{CaAl}_{3}\left(\mathrm{SO}_{4}\right)\left(\mathrm{PO}_{4}\right)(\mathrm{OH})_{6}$

$\mathrm{Al}_{3}\left(\mathrm{SO}_{4}\right)\left(\mathrm{PO}_{4}\right)(\mathrm{OH})_{6}$

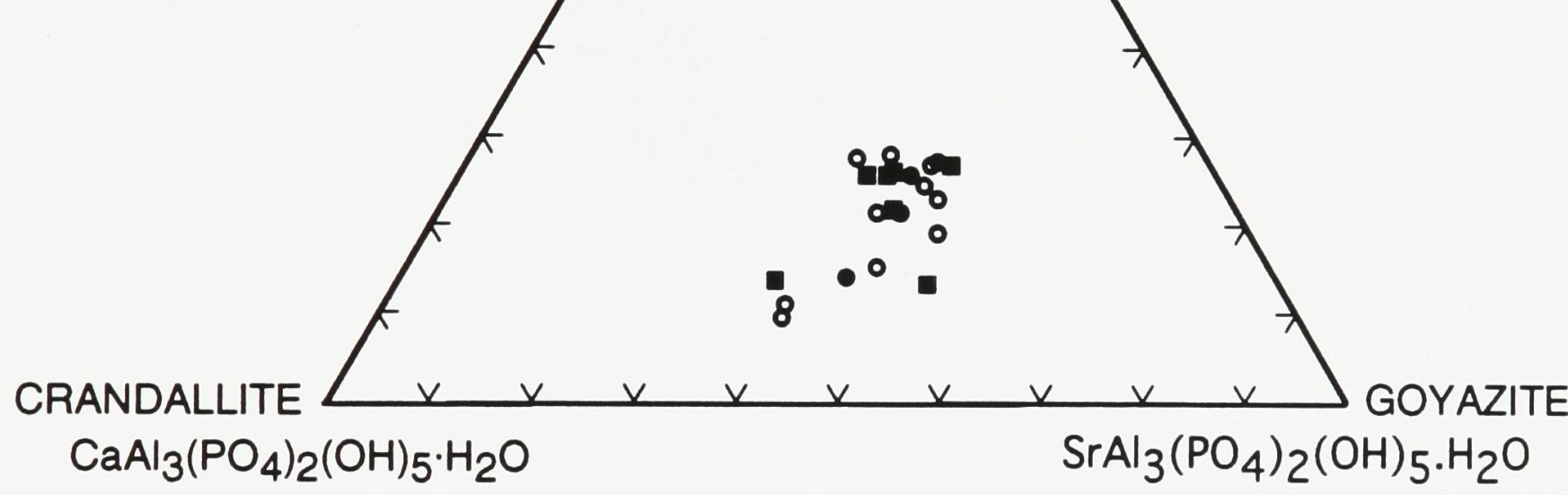

Fig. 3.1.23 

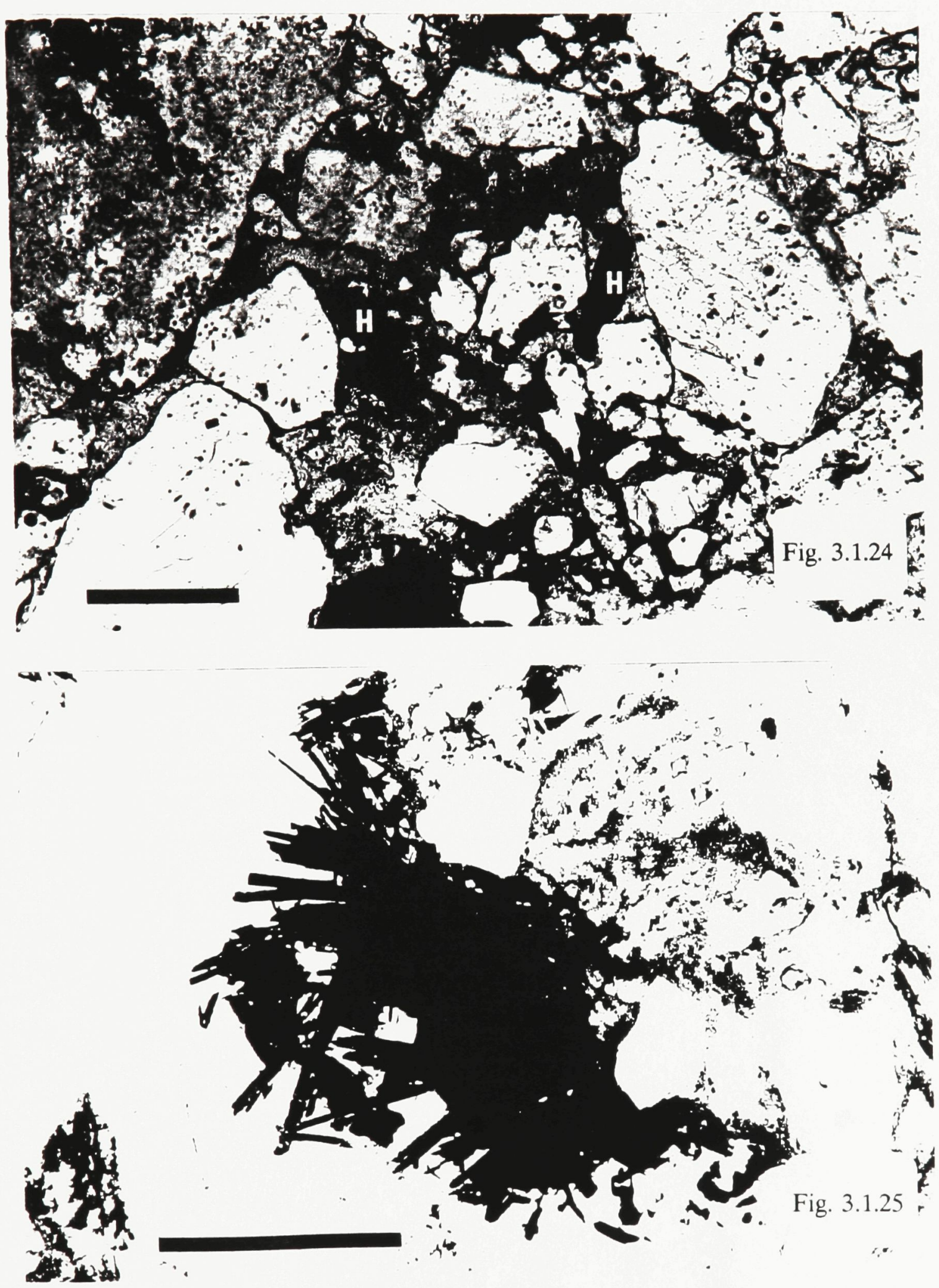


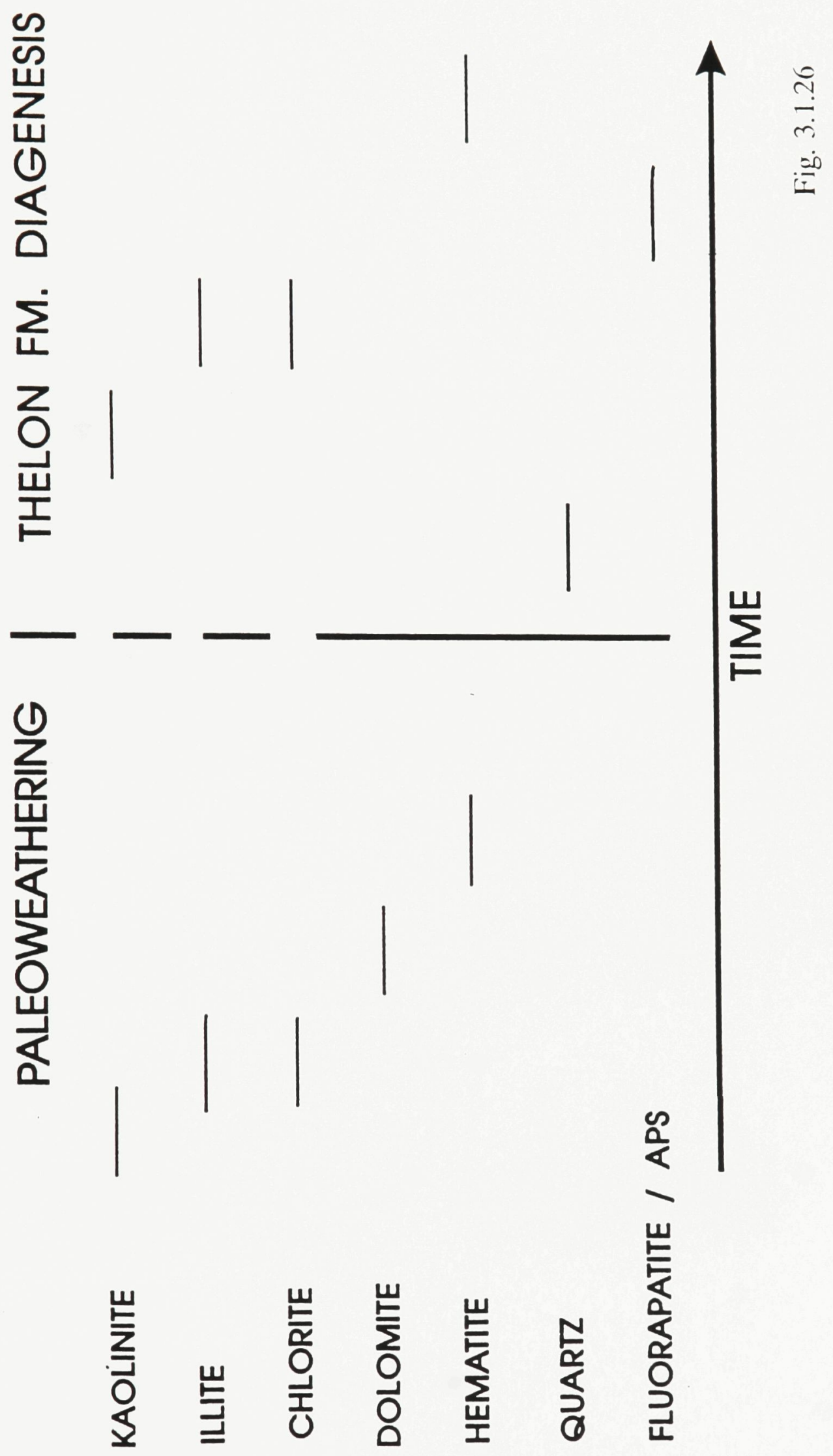




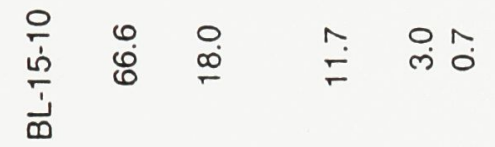

$$
\begin{aligned}
& \text { ஜे } \\
& \frac{\square}{\square}
\end{aligned}
$$

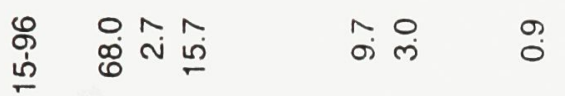

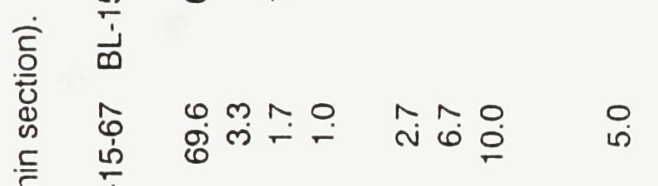

$$
\begin{aligned}
& \text { 产 }
\end{aligned}
$$

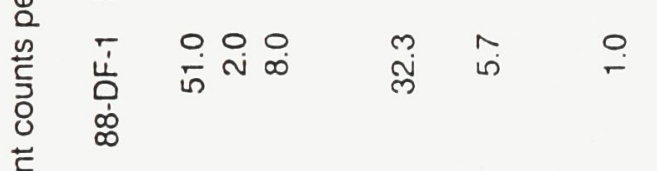

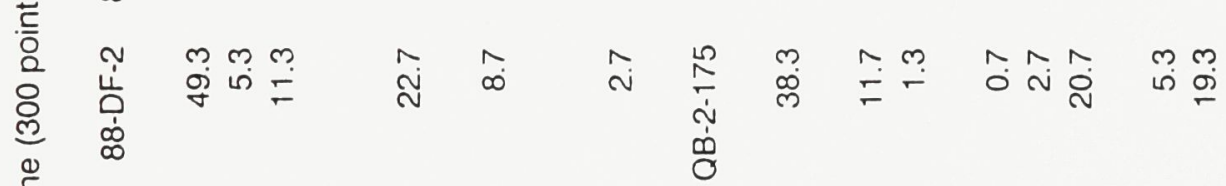

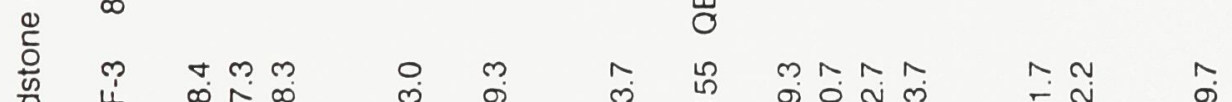

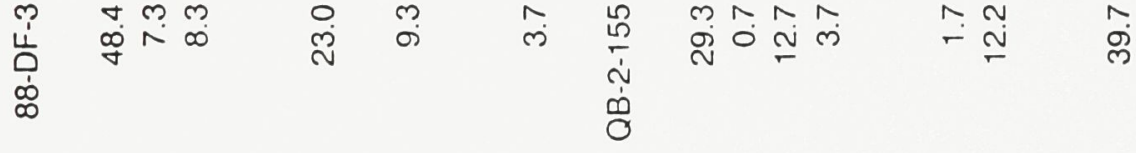

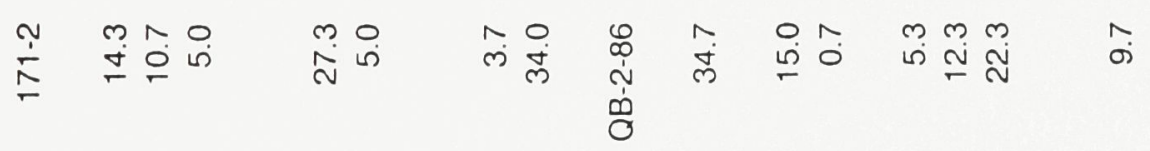

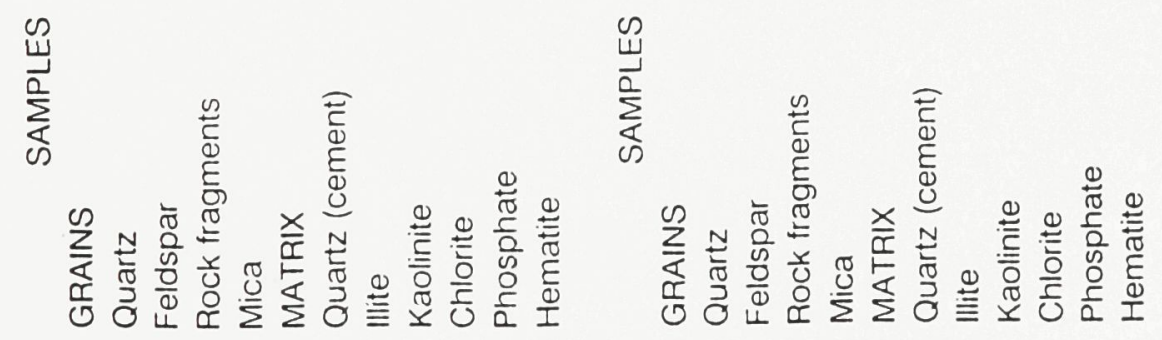




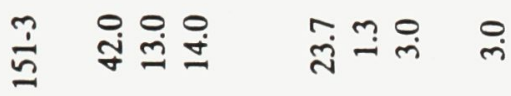

放

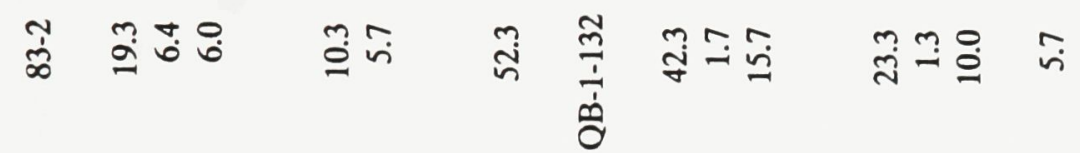

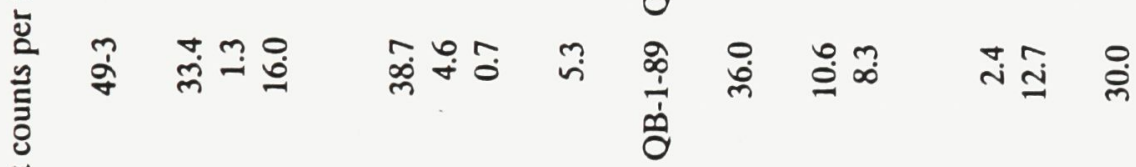

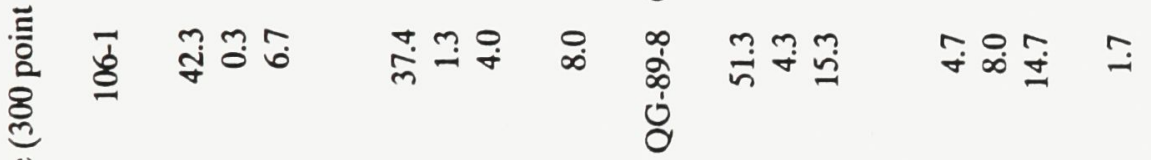

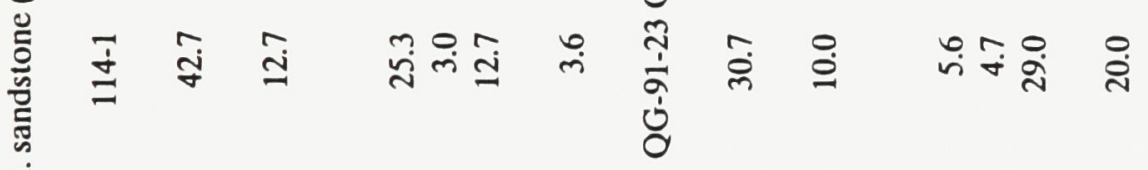

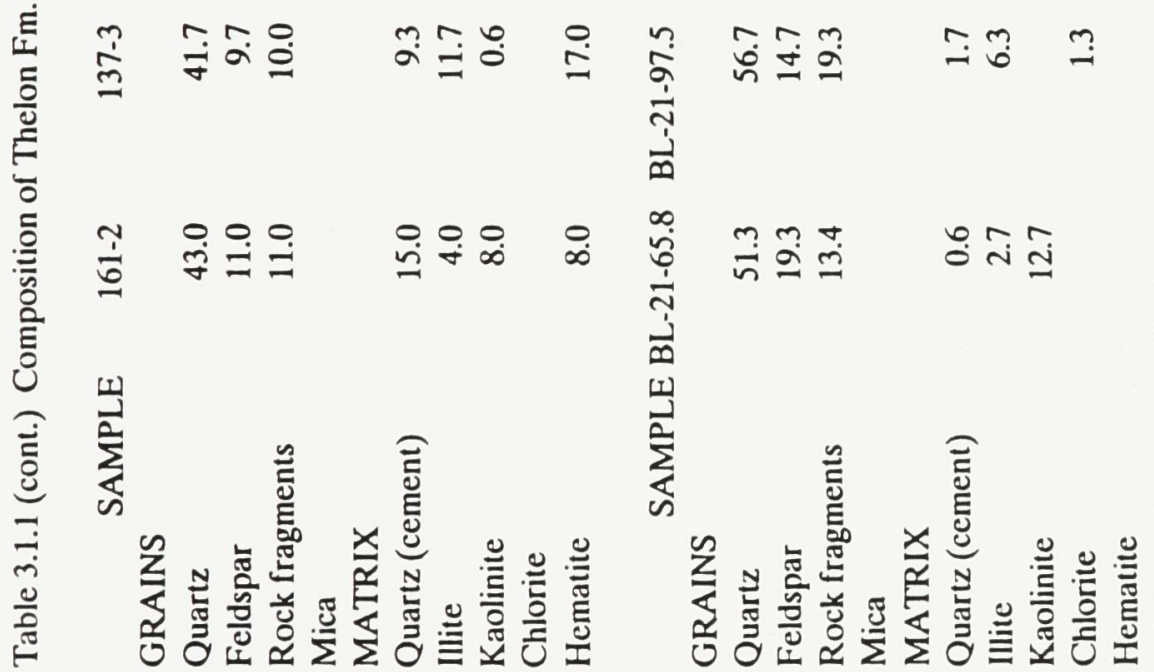




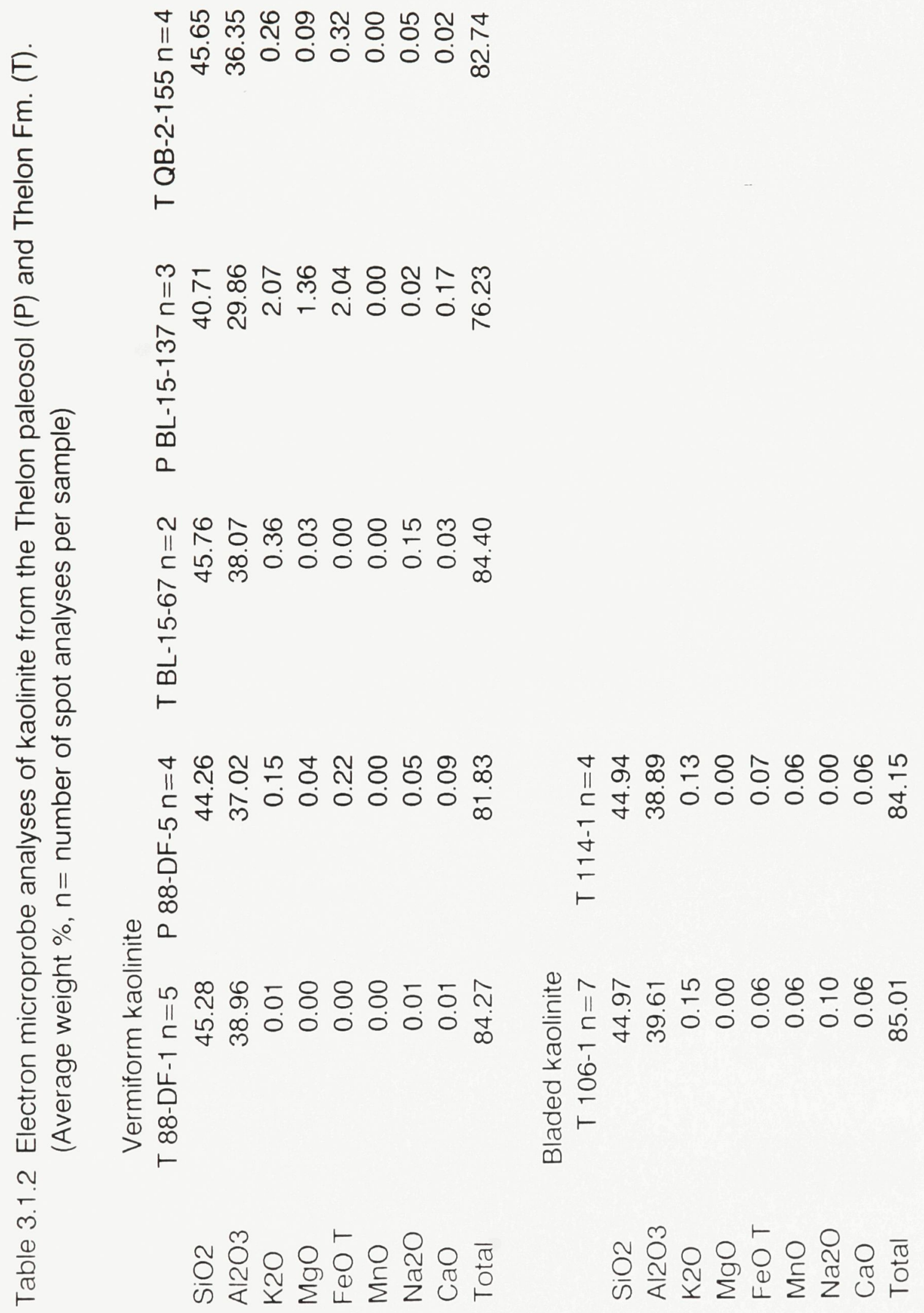



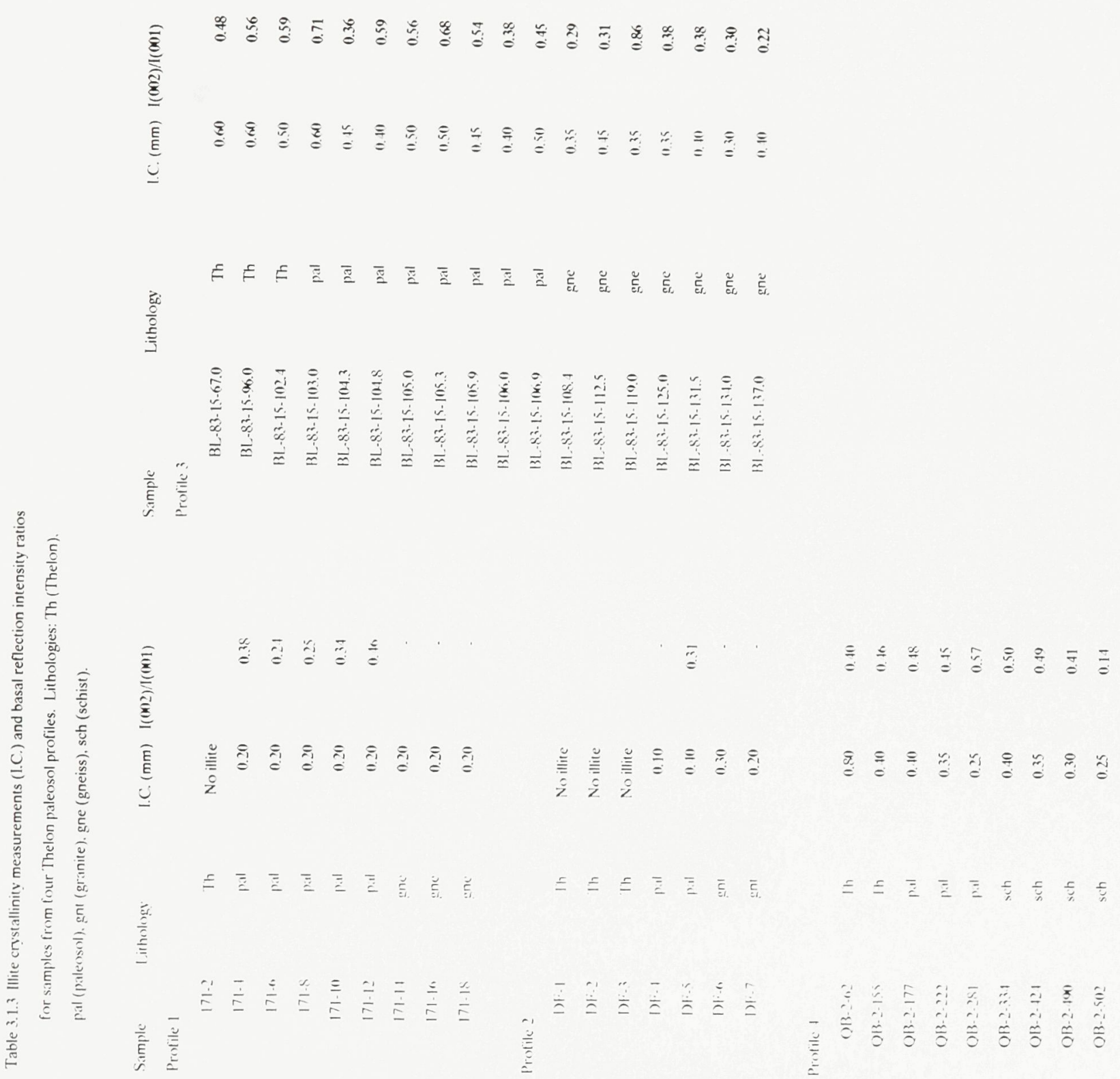


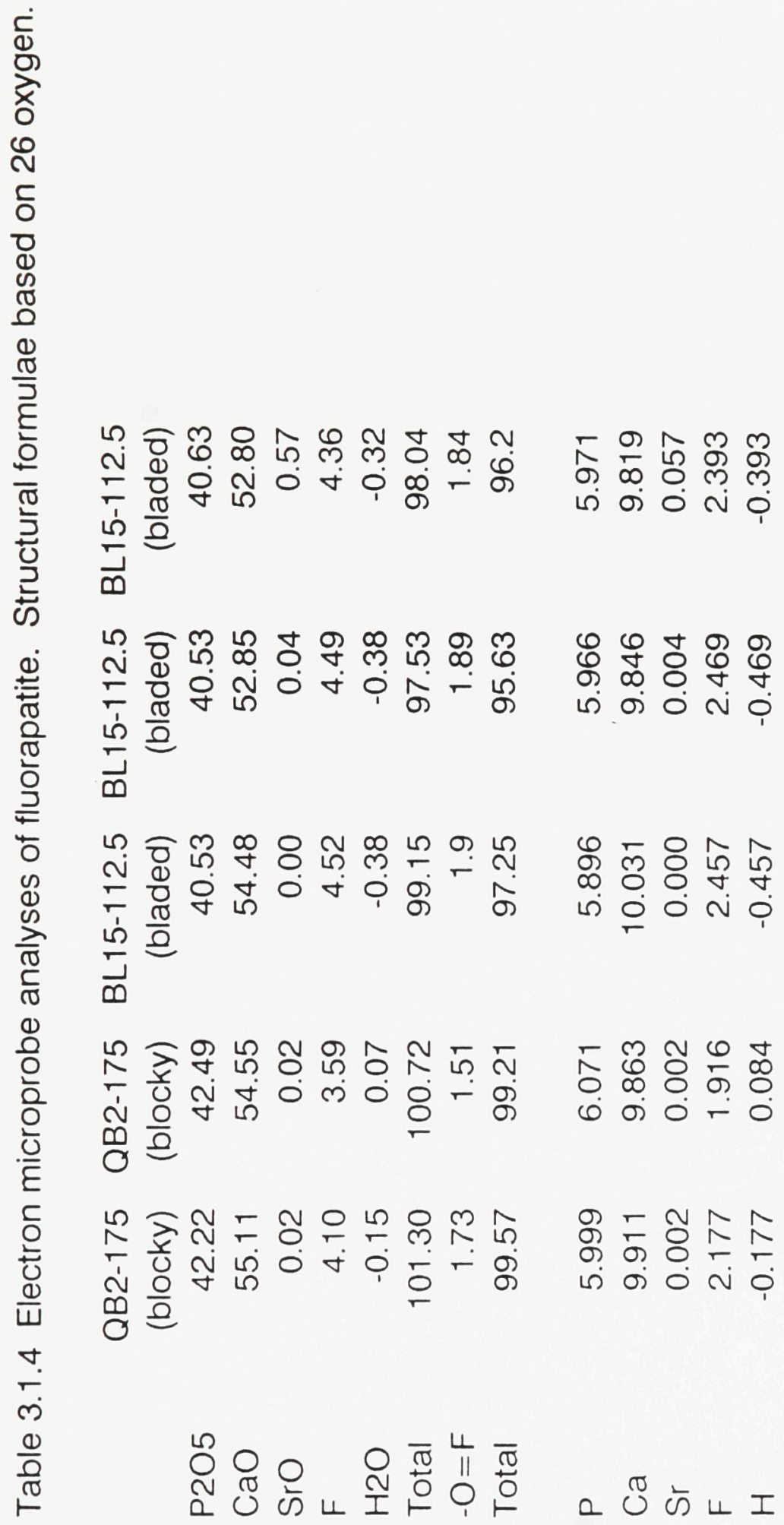




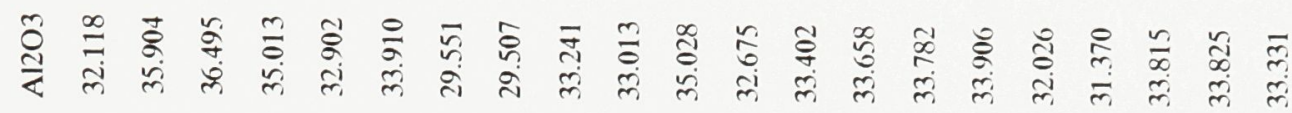

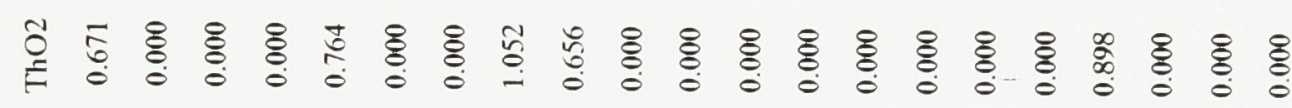

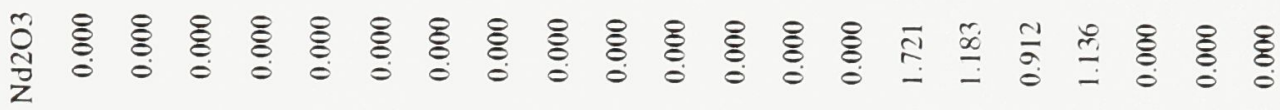

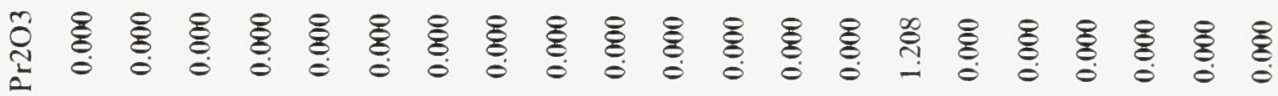

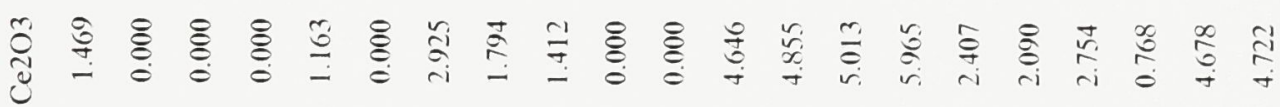

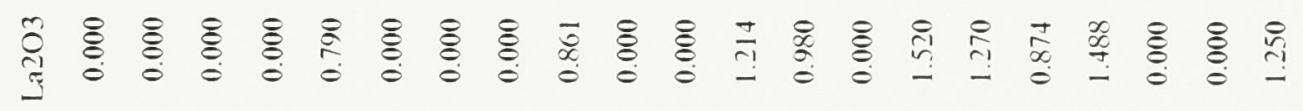

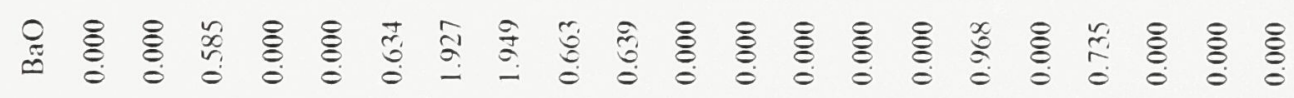

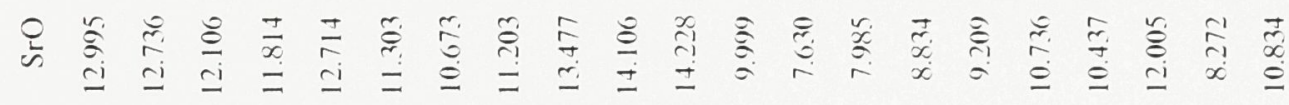

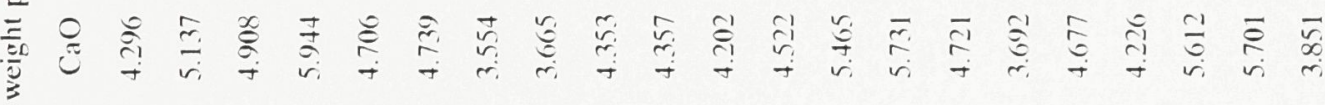

$\frac{0}{30}$

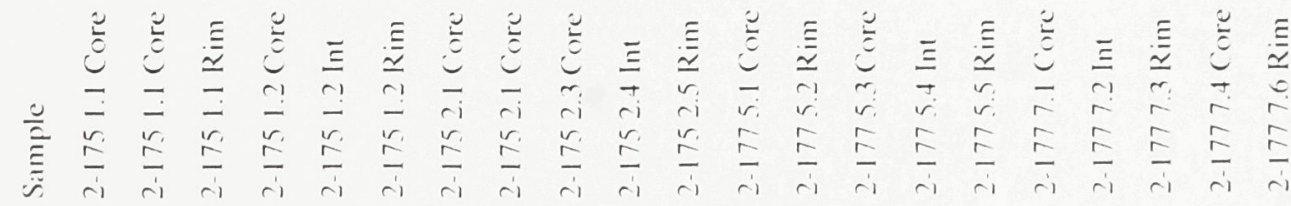


Table 3.1.5 (cont.)

Sample
2-175 1.1 Core
2-175 1.1 Core
2-175 1.1 Rim
2-175 1.2 Core
2-175 1.2 Int
2-175 1.2 Rim
2-175 2.1 Core
2-175 2.1 Core
2-175 2.3 Core
2-175 2.4 Int
2-175 2.5 Rim
2-177 5.1 Core
2-177 5.2 Rim
2-177 5.3 Core
2-177 5.4 Int
2-177 5.5 Rim
2-177 7.1 Core
2-177 7.2 Int
2-177 7.3 Rim
2-177 7.4 Core
2-177 7.6 Rim

Oxide weight percent

\begin{tabular}{|c|c|c|c|}
\hline $\mathrm{Fe} 2 \mathrm{O} 3$ & $\mathrm{P} 2 \mathrm{O} 5$ & $\mathrm{SO} 3$ & Total \\
\hline 1.532 & 22.742 & 7.823 & 83.646 \\
\hline 0.351 & 22.849 & 10.144 & 87.121 \\
\hline 0.328 & 22.916 & 9.178 & 86.516 \\
\hline 0.593 & 23.183 & 9.917 & 86.464 \\
\hline 1.781 & 22.598 & 8.092 & 85.510 \\
\hline 3.224 & 21.557 & 8.383 & 83.750 \\
\hline 2.374 & 23.813 & 5.480 & 80.297 \\
\hline 3.032 & 23.030 & 6.801 & 82.033 \\
\hline 1.523 & 24.144 & 8.769 & 89.099 \\
\hline 2.984 & 22.904 & 9.493 & 87.496 \\
\hline 0.994 & 23.209 & 9.662 & 87.323 \\
\hline 3.936 & 26.625 & 4.504 & 88.121 \\
\hline 2.285 & 27.378 & 3.938 & 85.933 \\
\hline 1.141 & 29.044 & 3.037 & 85.609 \\
\hline 2.544 & 26.060 & 3.592 & 89.947 \\
\hline 2.217 & 20.834 & 5.379 & 81.065 \\
\hline 1.212 & 24.215 & 6.583 & 83.325 \\
\hline 1.658 & 23.239 & 5.795 & 83.736 \\
\hline 0.652 & 23.804 & 9.072 & 85.728 \\
\hline 0.000 & 28.682 & 3.608 & 84.766 \\
\hline 0.666 & 28.161 & 4.182 & 86.997 \\
\hline
\end{tabular}




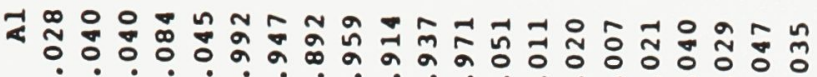 $\dot{m} \dot{m} \dot{m} \dot{m} \dot{m} \dot{N} \dot{N} \dot{N} \dot{N} \dot{N} \dot{N} \dot{m} \dot{m} \dot{m} \dot{m} \dot{m} \dot{m} \dot{m} \dot{m}$}

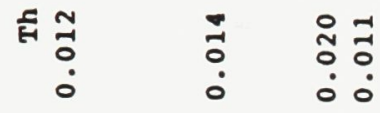
$\frac{1}{0}$

욜

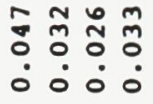

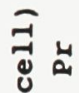

है

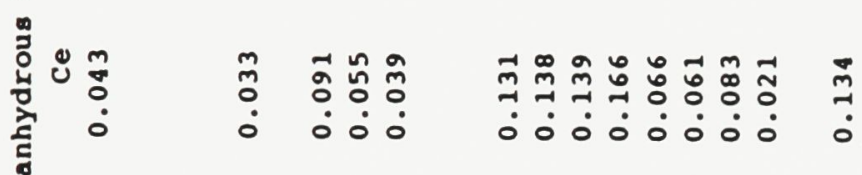

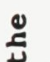

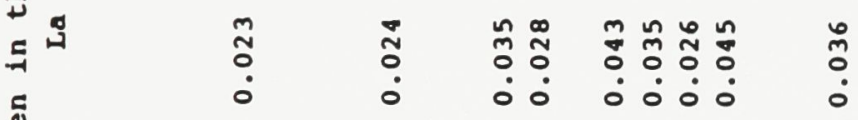

ปั.

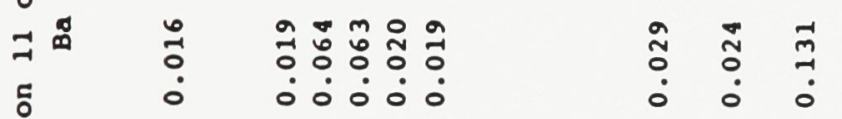

g

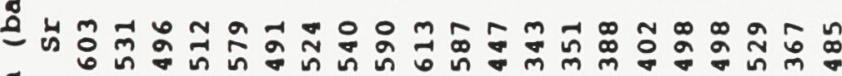
○

还

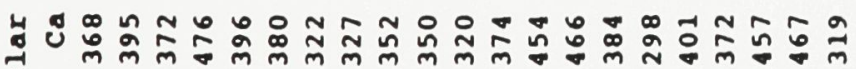

O̊

$-2$

ำ

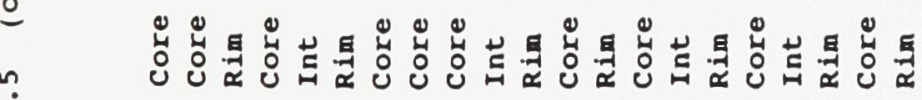

-

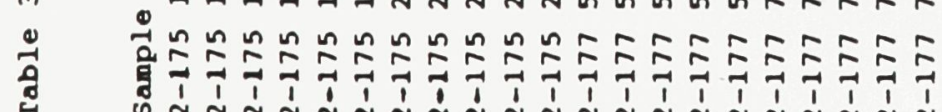


Table 3.1 .5 (cont.)

Molecular formula

Sample

2-175 1.1 Core

2-175 1.1 Core

2-175 1.1 Rim

2-175 1.2 Core

2-175 1.2 Int

2-175 1.2 Rim

2-175 2.1 Core

2-175 2.1 Core

2-175 2.3 Core

2-175 2.4 Int

2-175 2.5 Rim

2-177 5.1 Core

2-177 5.2 Rim

2-177 5.3 Core

2-177 $5.4 \mathrm{Int}$

2-177 5.5 Rim

2-1777.1 Core

2-177 7.2 Int

2-177 7.3 Rim

2-177 7.4 Core

2-177 7.6 Rim

$\begin{array}{rrr}\text { Fe3+ } & P & S \\ 0.092 & 1.540 & 0.470 \\ 0.019 & 1.390 & 0.547 \\ 0.017 & 1.371 & 0.487 \\ 0.033 & 1.467 & 0.556 \\ 0.105 & 1.503 & 0.477 \\ 0.182 & 1.366 & 0.471 \\ 0.151 & 1.706 & 0.348 \\ 0.190 & 1.621 & 0.424 \\ 0.087 & 1.544 & 0.497 \\ 0.168 & 1.452 & 0.534 \\ 0.053 & 1.398 & 0.516 \\ 0.229 & 1.739 & 0.261 \\ 0.133 & 1.796 & 0.229 \\ 0.065 & 1.866 & 0.173 \\ 0.145 & 1.673 & 0.204 \\ 0.126 & 1.327 & 0.304 \\ 0.073 & 1.641 & 0.395 \\ 0.103 & 1.618 & 0.358 \\ 0.037 & 1.532 & 0.518 \\ & 1.856 & 0.207 \\ 0.039 & 1.842 & 0.242 \\ & & \end{array}$


Table 3.1.6 Structural formulae for core (C), intermediate (I) and rim (R) areas of APS crystals using the general formula $\mathrm{AB}_{3}\left(\mathrm{XO}_{4}\right)_{2}(\mathrm{OH})_{6}$. Total iron as ferric iron.

QB-2-175

C Ca ${ }_{.36} \mathrm{Ce}{ }_{.04} \mathrm{Sr}_{.59}^{\mathrm{Th}}{ }_{.01}\left(\mathrm{Al}_{2.91} \mathrm{Fe} .09\right)\left(\mathrm{PO}_{4}\right)_{1.54}\left(\mathrm{SO}_{4}\right)_{.46}(\mathrm{OH})_{6}$

C Ca ${ }_{.43} \mathrm{Sr}_{.57}\left(\mathrm{Al}_{2.97} \mathrm{Fe}_{.03}\right)\left(\mathrm{PO}_{4}\right)_{1.44}\left(\mathrm{SO}_{4}\right)_{.56}(\mathrm{OH})_{6}$

C Ca ${ }_{.48} \mathrm{Sr}_{.52}\left(\mathrm{Al}_{2.97} \mathrm{Fe}_{.03}\right)\left(\mathrm{PO}_{4}\right)_{1.45}\left(\mathrm{SO}_{4}\right)_{.55}(\mathrm{OH})_{6}$

C Ba ${ }_{.06} \mathrm{Ca}_{.32} \mathrm{Ce}_{.10} \mathrm{Sr}_{.52}\left(\mathrm{Al}_{2.85} \mathrm{Fe}_{.15}\right)\left(\mathrm{PO}_{4}\right)_{1.66}\left(\mathrm{SO}_{4}\right)_{.34}(\mathrm{OH})_{6}$

C Ba ${ }_{.07} \mathrm{Ca}_{.32} \mathrm{Ce}{ }_{.05} \mathrm{Sr}_{.54} \mathrm{Th}_{.02}\left(\mathrm{Al}_{2.82^{2}} \mathrm{Fe}_{.18}\right)\left(\mathrm{PO}_{4}\right)_{1.58}\left(\mathrm{SO}_{4}\right)_{.42}(\mathrm{OH})_{6}$

C Ba ${ }_{.02} \mathrm{Ca}{ }_{.34} \mathrm{Ce}{ }_{.04} \mathrm{Sr}_{.56}{ }^{\mathrm{Th}}{ }_{.01} \mathrm{La}{ }_{.03}\left(\mathrm{Al}_{2.91} \mathrm{Fe} .09\right)\left(\mathrm{PO}_{4}\right)_{1.51}\left(\mathrm{SO}_{4}\right)_{.49}(\mathrm{OH})_{6}$

I Ca ${ }_{.38} \mathrm{Ce}_{.03} \mathrm{Sr}_{.55^{\mathrm{Th}}}{ }_{.02} \mathrm{La}{ }_{.02}\left(\mathrm{Al}_{2.90} \mathrm{Fe} .{ }_{.10}\right)\left(\mathrm{PO}_{4}\right)_{1.52}\left(\mathrm{SO}_{4}\right)_{.48}(\mathrm{OH})_{6}$

I Ba ${ }_{.02} \mathrm{Ca} .36 \mathrm{Sr}_{.62}\left(\mathrm{Al}_{2.84} \mathrm{Fe}_{.16}\right)\left(\mathrm{PO}_{4}\right)_{1.46}\left(\mathrm{SO}_{4}\right)_{.54}(\mathrm{OH})_{6}$

$\mathrm{R} \quad \mathrm{Ba}{ }_{.02} \mathrm{Ca} .42 \mathrm{Sr} .56\left(\mathrm{Al}_{2.97} \mathrm{Fe}_{.03}\right)\left(\mathrm{PO}_{4}\right)_{1.48}\left(\mathrm{SO}_{4}\right)_{.52}(\mathrm{OH})_{6}$

$\mathrm{R} \quad \mathrm{Ba}{ }_{.02} \mathrm{Ca} .43 \mathrm{Sr}_{.55}\left(\mathrm{Al}_{2.83} \mathrm{Fe}_{.17}\right)\left(\mathrm{PO}_{4}\right)_{1.49}\left(\mathrm{SO}_{4}\right)_{.51}(\mathrm{OH})_{6}$

R Ca ${ }_{35} \mathrm{Sr}_{.65}\left(\mathrm{Al}_{2.94} \mathrm{Fe} .06\right)\left(\mathrm{PO}_{4}\right)_{1.46}\left(\mathrm{SO}_{4}\right)_{.54}(\mathrm{OH})_{6}$

QB-2-175

C Ca ${ }_{.38} \mathrm{Ce}_{.13} \mathrm{Sr}_{.45^{\mathrm{La}} .04}\left(\mathrm{Al}_{2.79^{\mathrm{Fe}}}{ }_{.21}\right)\left(\mathrm{PO}_{4}\right)_{1.74}\left(\mathrm{SO}_{4}\right)_{.26}(\mathrm{OH})_{6}$

C Ca ${ }_{49} \mathrm{Ce}_{.14} \mathrm{Sr}_{.37}\left(\mathrm{Al}_{2.93} \mathrm{Fe}_{.07}\right)\left(\mathrm{PO}_{4}\right)_{1.84}\left(\mathrm{SO}_{4}\right)_{.17}(\mathrm{OH})_{6}$

C Ca ${ }_{.40} \mathrm{Ce}_{.06} \mathrm{Nd} .03 \mathrm{Sr} .48^{\mathrm{La}}{ }_{.03}\left(\mathrm{Al}_{2.93} \mathrm{Fe} .07\right)\left(\mathrm{PO}_{4}\right)_{1.61}\left(\mathrm{SO}_{4}\right)_{.39}(\mathrm{OH})_{6}$

C Ca ${ }_{.48} \mathrm{Ce} .{ }_{.14} \mathrm{Sr}_{.38^{\mathrm{Al}}}{ }_{3.00}\left(\mathrm{PO}_{4}\right)_{1.80}\left(\mathrm{SO}_{4}\right)_{.20}(\mathrm{OH})_{6}$

I Ca ${ }_{.36} \mathrm{Ce}{ }_{15^{\mathrm{Nd}}} \mathrm{Nd}{ }_{.04} \mathrm{Sr}{ }_{.37} \mathrm{Pr} .04{ }_{.04}^{\mathrm{La}}{ }_{.04}\left(\mathrm{Al}_{2.86} \mathrm{Fe}{ }_{.14}\right)\left(\mathrm{PO}_{4}\right)_{1.78}\left(\mathrm{SO}_{4}\right)_{.22}(\mathrm{OH})_{6}$

I Ba ${ }_{.03} \mathrm{Ca} .{ }_{.34} \mathrm{Ce}{ }_{00} 8^{\mathrm{Nd}}{ }_{.03} \mathrm{Sr}_{.46} \mathrm{Th}_{.02} \mathrm{La}{ }_{.04}\left(\mathrm{Al}_{2.90} \mathrm{Fe}{ }_{.10}\right)\left(\mathrm{PO}_{4}\right)_{1.64}\left(\mathrm{SO}_{4}\right)_{.36}(\mathrm{OH})_{6}$

$\mathrm{R} \mathrm{Ca}{ }_{.4} \mathrm{Ce}{ }_{.15} \mathrm{Sr}_{.35} \mathrm{La}_{.03}\left(\mathrm{Al}_{2.87} \mathrm{Fe}_{.13}\right)\left(\mathrm{PO}_{4}\right)_{1.77}\left(\mathrm{SO}_{4}\right)_{.23}(\mathrm{OH})_{6}$

$\mathrm{R} \mathrm{Ba}{ }_{03} \mathrm{Ca}{ }_{.35} \mathrm{Ce}{ }_{.07} \mathrm{Nd}_{.04} \mathrm{Sr} .46{ }_{.04}^{\mathrm{La}}\left(\mathrm{Al}_{2.88} \mathrm{Fe}_{.12}\right)\left(\mathrm{PO}_{4}\right)_{1.62}\left(\mathrm{SO}_{4}\right)_{.38}(\mathrm{OH})_{6}$

$\mathrm{RCa}{ }_{.45} \mathrm{Ce} .03 \mathrm{Sr} .52\left(\mathrm{Al}_{2.96} \mathrm{Fe}_{.04}\right)\left(\mathrm{PO}_{4}\right)_{1.49}\left(\mathrm{SO}_{4}\right)_{.51}(\mathrm{OH})_{6}$

R Ca ${ }_{.33} \mathrm{Ce}{ }_{.13} \mathrm{Sr}_{.50} \mathrm{La}{ }_{.04}\left(\mathrm{Al}_{2.96} \mathrm{Fe}_{.04}\right)\left(\mathrm{PO}_{4}\right)_{1.76}\left(\mathrm{SO}_{4}\right)_{.24}(\mathrm{OH})_{6}$ 
Table 3.1.7 A comparison of kaolinite, illite and chlorite within the Thelon paleosol (pedogenic) and Thelon $\mathrm{Fm}$. sandstone (diagenetic).

\begin{tabular}{|c|c|c|}
\hline & PEDOGENIC & DIAGENETIC \\
\hline \multicolumn{3}{|l|}{ KAOLINITE } \\
\hline Texture & $\begin{array}{l}\text { Blocky to } \\
\text { vermiform books }\end{array}$ & $\begin{array}{l}\text { Blocky to } \\
\text { vermiform books, } \\
\text { bladed }\end{array}$ \\
\hline Distribution & $\begin{array}{l}\text { Within and rimming } \\
\text { feldspar }\end{array}$ & $\begin{array}{l}\text { Pervasive pore } \\
\text { filling }\end{array}$ \\
\hline other features & $\begin{array}{l}\text { Minor paleosol } \\
\text { component }\end{array}$ & $\begin{array}{l}\text { Abundant sandstone } \\
\text { component, post- } \\
\text { dates quartz } \\
\text { cement }\end{array}$ \\
\hline \multicolumn{3}{|l|}{ ILLITE } \\
\hline Texture & $\begin{array}{l}\text { Fibrous- } \\
\text { individual to } \\
\text { massive and } \\
\text { rosette, } \\
\text { pseudomorphous } \\
\text { after kaolinite }\end{array}$ & $\begin{array}{l}\text { Fibrous- } \\
\text { individual to } \\
\text { massive, } \\
\text { pseudomorphous } \\
\text { after kaolinite }\end{array}$ \\
\hline Distribution & $\begin{array}{l}\text { Feldspar } \\
\text { alteration and } \\
\text { interstitial }\end{array}$ & Interstitial \\
\hline other features & $\begin{array}{l}\text { Common component, } \\
\text { commonly moderate } \\
\text { to well } \\
\text { crystallized } \\
\left(I . C .<.42 \Delta^{\circ} 2 \theta\right)\end{array}$ & $\begin{array}{l}\text { Minor sandstone } \\
\text { component, } \\
\text { commonly aluminous } \\
\text { and poorly } \\
\text { crystallized } \\
\left(I . C .>.42 \Delta^{\circ} 2 \theta\right)\end{array}$ \\
\hline \multicolumn{3}{|l|}{ CHLORITE } \\
\hline Texture & Fibrous & Fibrous \\
\hline Distribution & $\begin{array}{l}\text { Biotite and } \\
\text { hornblende } \\
\text { alteration }\end{array}$ & $\begin{array}{l}\text { Biotite } \\
\text { alteration, } \\
\text { interstitial }\end{array}$ \\
\hline other features & $\begin{array}{l}\text { Minor to common } \\
\text { paleosol component }\end{array}$ & $\begin{array}{l}\text { Minor sandstone } \\
\text { component }\end{array}$ \\
\hline
\end{tabular}


CHAPTER THREE

SECTION TWO

STABLE ISOTOPE ANALYSIS OF KAOLINITE 


\section{INTRODUCTION}

There is increasing evidence, particularly within the last decade, that unconformities, and their attendant paleosols, have been altered by fluids emanating from overlying basin successions (e.g., Al-Gailani, 1981; Velbel, 1985; Haynes, 1988; Duffin et al., 1989; Nesbitt and Young, 1989; Driese and Foreman, 1990; Lander et al., 1991; Lidiak and Ceci, 1991; Retallack, 1991; Bestland and Retallack, 1993). Indeed, thin section petrography and major oxide and trace element analyses of the Thelon paleosol and overlying Thelon Formation sandstone (Section One, Chapter Two and Section One, Chapter Three) reveal that the paleoweathered unconformity at the base of the Thelon Basin has similarly been altered during burial diagenesis of the Thelon Formation. This alteration is manifested: (a) as anomalous element gains at the top of the Thelon paleosol where it is in contact with the overlying Thelon Formation, and (b) by the presence of quartz veinlets, the APS mineral, and illitized kaolinite within the Thelon paleosol, which overprint paleoweathering features. Furthermore, phyllosilicates in the Thelon paleosol and Thelon Formation sandstone are for the most part petrographically identical (e.g., Table 3.1.7), suggesting that pedogenic phyllosilicates which initially formed in the Thelon paleosol were subsequently altered during burial diagenesis of the Thelon Formation.

The presence of hydroxyl ion, oxygen, and, commonly, interlayer water in the phyllosilicate structure makes them amenable to oxygen and hydrogen stable isotope studies. Many studies have shown that phyllosilicates are sensitive to changes in the 
stable isotope composition of the ambient water-dominated fluids; even at relatively low temperatures $\left(\mathrm{O}^{0}-30^{\circ} \mathrm{C}\right)$, slow reacting meteoric water is associated with weathering (e.g., Sheppard et al., 1969; Savin and Epstein, 1970; Lawrence and Taylor, 1971; O’Neil and Kharaka, 1976). For a few phyllosilicates, such as kaolinite, experimentally and empirically derived mineral-water isotopic fractionation factors may be used to determine the isotopic composition of the water-dominated fluids from which a particular phyllosilicate was formed. Determining the isotopic composition of the fluids may indicate whether they were of meteoric, diagenetic (burial), metamorphic or igneous origin.

The oxygen and hydrogen isotopic compositions of kaolinite from the Thelon paleosol and Thelon Formation were determined, with the hope that the isotopic data might distinguish between kaolinites in the two lithologies which otherwise are petrographically indistinguishable. On the one hand, if the kaolinite samples from the two lithologies display different isotopic signatures, then one could conclude that they formed from different fluids, unless, coincidentally, the paleoweathering meteoric fluids were identical to the subsequent diagenetic fluids. If, on the other hand, the phyllosilicate isotopic signatures were essentially similar, then one could conclude that either (a) the isotopic composition of the Thelon paleosol phyllosilicate was affected by diagenetic fluids emanating from the Thelon Formation, or (b) that they were formed at the same time by the same fluid. 


\section{SAMPLING AND ANALYTICAL TECHNIQUE}

Kaolinite was used primarily because millimetre-scale aggregates of the mineral could be seen in both Thelon paleosol and Thelon Formation sandstone samples, and relatively pure kaolinite could be extracted. In comparison, illite and chlorite occur as disseminated and finer-grained fibrous growths, occasionally intergrown, but sufficient amounts of discrete illite or chlorite could not be extracted.

Kaolinite was picked from paleosol and sandstone samples using a metal needle. Some of this material was oriented on a glass slide and scanned using XRD to determine the relative amounts of other minerals that might have been unintentionally picked out with kaolinite. Quartz was the only other mineral detected by XRD. An estimate of the relative abundance of quartz in the sample was determined by constructing an intensity-concentration calibration curve (Kodama et al., 1977) using known mixtures of kaolinite and quartz. From the intensityconcentration calibration curve, the relative abundance of quartz in the 11 samples was $<5 \%$; this amount of quartz contamination is not considered to have significantly influenced the oxygen isotope compositions obtained for the samples.

Kaolinite from 11 drill core and outcrop samples was analyzed. The stable isotope extractions, and analysis by mass spectrometer, were performed by Dr. B. Taylor, Geological Survey of Canada, Ottawa. Analytical instrumentation, procedures and precision are outlined in Appendix I. Isotopic compositions are 
expressed as delta $(\delta)$, the relative difference between the isotope ratio of the sample and the V-SMOW standard, in parts per thousand (\%o). For one Thelon Formation sandstone sample (QB-1-57), too little kaolinite remained after oxygen isotope analyses to permit hydrogen isotope analyses.

\section{RESULTS}

The stable isotope composition of kaolinite from the Thelon paleosol and Thelon Formation sandstone samples are listed in Table 3.2.1, and the distribution of their $\delta$ values are shown in Fig. 3.2.1. The analyses are also plotted on a $\delta \mathrm{D}$ vs. $\delta^{18} \mathrm{O}$ plot, Fig. 3.2.2, on which the present-day global meteoric line (MWL) and kaolinite stability lines at $25^{\circ} \mathrm{C}$ (weathering), $50^{\circ} \mathrm{C}$ and $100^{\circ} \mathrm{C}$ are plotted. The present-day global meteoric water line (Craig, 1961) represents the average stable isotope compositions of most surface waters, which systematically decrease towards the Earth's poles. The kaolinite line for $25^{\circ} \mathrm{C}$ (Savin and Epstein, 1970) represents the stable isotope compositions for kaolinite formed by weathering in equilibrium with modern meteoric waters that plot along the MWL. The calculated kaolinite lines at $50^{\circ} \mathrm{C}$ and $100^{\circ} \mathrm{C}$ are from Kyser (1987). The $50^{\circ} \mathrm{C}$ kaolinite line corresponds to the supergene/hypogene (S/H) line of Sheppard et al. (1969). Based on a study of porphyry copper deposits by Sheppard et al., (1969), the S/H line distinguishes kaolinite formed under high-temperature hypogene conditions (left of $\mathrm{S} / \mathrm{H}$ line) from kaolinite formed by subsequent low-temperature supergene conditions (right of $\mathrm{S} / \mathrm{H}$ line). 
The oxygen and hydrogen stable isotope compositions for kaolinite from the Thelon paleosol and Thelon Formation are similar (Figs. 3.2.1 and 3.2.2). There is an overlap in the range of $\delta \mathrm{D}$ values for kaolinite from the two lithologies. Although there is a $\delta^{18} \mathrm{O}$ difference of $<1 \%$ o between some samples from the two lithologies, the Thelon Formation kaolinite has slightly higher $\delta^{18} \mathrm{O}$ values than the Thelon paleosol kaolinite. There is no systematic stratigraphic trend in $\delta \mathrm{D}$ or $\delta^{18} \mathrm{O}$ values between samples from Profile 2 (i.e., samples DF-88-1, -3, -4, -5). The paleosol sample from Profile 1 (171-12) has a higher (heavier) $\delta \mathrm{D}$ value and a lower (lighter) $\delta^{18} \mathrm{O}$ value compared to the Profile 1 sandstone sample (171-2B); this demonstrates a lack of systematic isotopic change between the two lithologies.

Fig. 3.2.1 shows that the Thelon paleosol kaolinite has a similar range in $\delta \mathrm{D}$ and $\delta^{18} \mathrm{O}$ values to kaolinite in other weathering profiles, but also has similar $\delta^{18} \mathrm{O}$ values to diagenetic kaolinite from Thelon sandstones in general. From Fig. 3.2.2, it is apparent that: (1) all the samples cluster to the left of the kaolinite weathering line, (2) Thelon Formation samples plot closer to the kaolinite weathering line than the Thelon paleosol samples, and (3) kaolinite from the Thelon paleosol samples plot near the $50^{\circ} \mathrm{C}$ kaolinite line.

Although there are no direct indications of the temperature of formation for the kaolinite, based on the clustering of analyses about the $50^{\circ} \mathrm{C}$ kaolinite line (Fig. 3.2.2), and the general low temperature $\left(<200^{\circ} \mathrm{C}\right)$ diagenetic state of the Thelon 
Formation (Chapter Three, Section One), one might use the $50^{\circ} \mathrm{C}$ isotherm as an estimated temperature for kaolinite re-equilibration or formation. Using $50^{\circ} \mathrm{C}$, calculations were made to estimate the $\delta \mathrm{D}$ and $\delta^{18} \mathrm{O}$ composition of the fluids from which the kaolinite re-equilibrated or formed. The hydrogen isotope fractionation factor of Lambert and Epstein (1980) for kaolinite and water $(1000 \ln \alpha=$ $\left.4.53\left(10^{6} / \mathrm{T}^{2}\right)+19.4\right)$, and the oxygen isotope fractionation factor of Land and Dutton (1978) for kaolinite and water $\left(1000 \ln \alpha=2.5\left(10^{6} / \mathrm{T}^{2}\right)-2.9\right)$, were used in the calculations. Table 3.2.2 shows the results of these calculations, which are also plotted in Fig. 3.2.2. The calculated isotopic composition of the waters which would be in equilibrium with kaolinite at $50^{\circ} \mathrm{C}$ plot close to the MWL (Fig. 3.2.2, $50^{\circ} \mathrm{C}$ field), in a position that is similar to present-day mid-latitude North American meteoric water.

\section{DISCUSSION}

The stable isotope composition of kaolinite from samples of the Thelon paleosol and Thelon Formation sandstone cluster close to the $50^{\circ} \mathrm{C}$ isotherm for kaolinite stability. Although the Thelon Formation samples plot closer to the weathering line than Thelon paleosol samples, there are too few Thelon Formation samples to determine if Thelon Formation kaolinite generally has a heavier $\delta^{18} \mathrm{O}$ composition than Thelon paleosol kaolinite.

The isotopic composition of kaolinite from the Thelon paleosol samples is 
compatible with kaolinite formed during low-temperature burial diagenesis from meteoric pore waters. Some of the Thelon paleosol kaolinites plot to the left of the $50^{\circ} \mathrm{C}$ kaolinite line, within the hypogene field of Sheppard et al. (1969), and thus might be considered to be products of hydrothermal alteration. However, kaolinite from these Thelon paleosol samples likely did not form as a result of hydrothermal alteration because: (a) the samples plot to the right of the $100^{\circ} \mathrm{C}$ kaolinite line; (b) kaolinite in the Thelon paleosol is areally widespread, and not restricted to fault zones; and (c) there are no other high temperature alteration minerals that might be considered to have formed as a result of hydrothermal alteration.

All the kaolinite samples are out of equilibrium with present-day meteoric surface waters. Based on $\delta \mathrm{D}$ values for present-day meteoric water for North America compiled by Sheppard et al. (1969, Fig. 4), the study area has present-day $\delta \mathrm{D}$ values between $-130 \%$ and $-150 \%$, and, using the formula $\delta \mathrm{D}=8 \delta^{18} \mathrm{O}+10$ (Craig, 1961), $\delta^{18}$ O values between $-17.5 \%$ and $-20.0 \%$. Kaolinite produced from meteoric water with this range of stable isotope composition would have a much lighter isotopic composition than that determined for the samples. Therefore, these results indicate that the formation of kaolinite in the Thelon paleosol and Thelon Formation is not a modern phenomenon.

The evidence thus far presented suggests that kaolinite in the Thelon paleosol has been affected by diagenetic re-equilibration following burial of the paleosol by 
the Thelon Formation sediments. Independent evidence for diagenetic overprinting of the Thelon paleosol has already been presented (Chapter Three Section One). A minimum burial temperature of $50^{\circ} \mathrm{C}$ for the base of the Thelon Formation and, therefore, the Thelon paleosol, is suggested by conservative geothermal gradient estimates $\left(2 \mathrm{~km}\right.$ @ $\left.25^{\circ} \mathrm{C} / \mathrm{km}\right)$, which is compatible with clustering of the Thelon Formation kaolinite around the $50^{\circ} \mathrm{C}$ kaolinite line (Fig. 3.2.2). It is unlikely however, that complete re-equilibration of the pedogenic kaolinite has occurred, as experiments conducted by O'Neil and Kharaka (1976) and Yeh and Savin (1977) suggest that complete oxygen- and hydrogen-isotope exchange between phyllosilicates and water is unlikely to occur below $100^{\circ} \mathrm{C}$.

Two other studies of kaolinite in weathering profiles have demonstrated the effects of diagenetic re-equilibration on pedogenic kaolinite. In the first, Bird and Chivas (1988) studied the $\delta \mathrm{D}$ and $\delta^{18} \mathrm{O}$ composition of Permian-age kaolinite from weathering profiles in the Gunnedah Basin, Australia, and noted that the kaolinite analyses plotted in the hypogene field above the kaolinite weathering line. They attributed this vertical shift of isotopic composition away from the kaolinite line to post-formational hydrogen isotope exchange with younger diagenetic fluids. The ranges of reported $\delta \mathrm{D}$ and $\delta^{18} \mathrm{O}$ values for this study are shown in Fig. 3.2.1.

In the second study, Wilson and Kyser (1987) analyzed the $\delta \mathrm{D}$ and $\delta^{18} \mathrm{O}$ compositions of kaolinite within the sub-Athabasca Group paleosol and basal 
Athabasca Group sandstone, as part of a larger study of alteration associated with the unconformity-type uranium deposits at the base of the Proterozoic Athabasca Basin. They discovered that the $\delta \mathrm{D}$ and $\delta^{18} \mathrm{O}$ values of kaolinite from unmineralized paleosol and sandstone samples are very similar, and plot to the left of the kaolinite weathering line. They concluded that the original kaolinite in the paleosol had been overprinted by approximately $200^{\circ} \mathrm{C}$ diagenetic basinal fluids.

The study of Wilson and Kyser (1987) is of further importance because the paleoweathering and subsequent sedimentation associated with the Athabasca Basin is chronostratigraphically correlative with the Thelon paleosol and Thelon Formation (Chapter Four). The kaolinite samples from the Athabasca Group and underlying paleosol are isotopically lighter than those from this study. This difference may be due to two factors. First, the higher diagenetic temperatures $\left(\sim 200^{\circ} \mathrm{C}\right.$; Pagel et al., 1980; Hoeve et al., 1981; Wilson and Kyser, 1987; Kotzer et al., 1992) affecting the Athabasca kaolinite may have allowed more complete isotopic re-equilibration of pedogenic kaolinite, compared to the lower temperatures $\left(<200^{\circ} \mathrm{C}\right)$ which appear to have affected the Thelon kaolinite samples. Second, a difference in paleo-latitude, altitude, or -continentality (Yurtsever and Gat, 1981) may have produced differences in the isotopic composition of the meteoric water which caused the Proterozoic weathering, and which eventually may have mixed with formational fluids to form burial diagenetic fluids. 
Hematite in the Athabasca Group and underlying paleosol has a paleomagnetic pole of $12^{\circ} \mathrm{N}$ and $271^{\circ} \mathrm{E}$ (Fahrig et al., 1978; Kotzer et al., 1992), which places the Athabasca Basin at approximately $39^{\circ} \mathrm{N}$ paleolatitude. Present-day midcontinental United States, at $39^{\circ} \mathrm{N}$, has meteoric water $\delta \mathrm{D}$ values of approximately -40\%o to -50\%o (Sheppard et al., 1969). Interestingly, the kaolinite from the Thelon paleosol and Thelon Formation, and their potential formational fluids, have ranges of $\delta \mathrm{D}$ and $\delta \mathrm{D}_{\text {water }}$ values (-20\%o to $-63 \%$ ) similar to present-day midcontinental meteoric fluids. If a paleometeoric component is still present in the $\delta \mathrm{D}$ and $\delta^{18} \mathrm{O}$ values for the Thelon samples, then an approximate $39^{\circ} \mathrm{N}$ paleolatitude for the continental Athabasca and Thelon basins would be supported by the range of $\delta \mathrm{D}$ and $\delta \mathrm{D}_{\text {water }}$ values for the Thelon samples.

\section{CONCLUSIONS AND INTERPRETATIONS}

Oxygen and hydrogen isotope analyses evidently do not distinguish between kaolinite from the Thelon paleosol and Thelon Formation. Therefore, the Thelon paleosol cannot be distinguished from the Thelon Formation on the basis of either its mineralogic composition (as previously discussed in Chapter Three Section One), or on the basis of stable isotope composition of the kaolinite.

Since the $\delta \mathrm{D}$ and $\delta^{18} \mathrm{O}$ composition of kaolinite in the Thelon paleosol is almost identical to kaolinite in the overlying Thelon Formation, it is concluded that the kaolinite in the paleosol, considered to have originally formed from low- 
temperature meteoric water, has been, at least partly, re-equilibrated with burial diagenetic fluids emanating from the Thelon Formation.

Clustering of the isotopic composition of kaolinite from the Thelon paleosol and Thelon Formation sandstone around the $50^{\circ} \mathrm{C}$ isotherm for kaolinite stability, suggests that the formation of diagenetic kaolinite in the Thelon Formation and the diagenetic overprinting of the Thelon paleosol occurred at a relatively low temperature, possibly about $50^{\circ} \mathrm{C}$. Based on this temperature estimate, calculated formational water compositions have isotopic compositions similar to present-day midcontinental (midlatitude) North American meteoric water.

\section{REFERENCES}

Al-Gailani, M.B. 1981. Authigenic mineralizations at unconformities: implication for reservoir characteristics. Sedimentary Geology, v. 29, pp. 89-115.

Bestland, E.A. and Retallack, G.J. 1993. Volcanically influenced calcareous paleosols from the Miocene Kiahera Formation, Rusinga Island, Kenya. Journal of the Geological Society, London, v. 150, pp. 293-310.

Bird, M.I. and Chivas, A.R. 1988. Stable-isotope evidence for low-temperature kaolinitic weathering and post-formational hydrogen-isotope exchange in Permian 
kaolinites. Chemical Geology, v. 72, pp. 249-265.

Clayton, R.N., Friedman, I., Graf, D.L., Mayeda, T.K., Meents, W.F. and Shimp, N.F. 1966. The origin of saline formation waters: I. Isotopic composition. Journal of Geophysical Research, v. 71, pp. 3869-3882.

Craig, H. 1961. Isotopic variations in meteoric waters. Science, v. 133, pp. 1702-1703.

Driese, S.G. and Foreman, J.L. 1992. Paleopedology and paloclimatic implications of late Ordovician vertic paleosols, Juniata Formation, southern Appalachians. Journal of Sedimentary Petrology, v. 62, pp. 71-83.

Duffin, M.E., Lee, M., Klein, G.DeV. and Hay, R.L. 1989. Potassic diagenesis of Cambrian sandstones and Precambrian granitic basement in UPH-3 deep hole, upper Mississippi valley, U.S.A. Journal of Sedimentary Petrology, v. 59, pp. 848-861.

Dutton, S.P. and Land, L.S. 1985. Meteoric burial diagenesis of Pennsylvanian arkosic sandstones, southwestern Anadarko Basin, Texas. The American Association of Petroleum Geologists Bulletin, v. 68, pp. 22-38.

Fahrig, W.F., Christie, K.W. and Freda, G. 1978. The paleolatitude and paleomagnetic age of the Athabasca Formation, northern Saskatchewan. Geological 
Survey of Canada, Paper 78-1C, pp. 1-6.

Hassanipak, A.A. and Eslinger, E. 1985. Mineralogy, crystallinity, $\mathrm{O}^{18} / \mathrm{O}^{16}$, and D/H of Georgia kaolins. Clays and Clay Minerals, v. 33, pp. 99-106.

Haynes, F.M. 1988. Fluid-inclusion evidence of basinal brines in Archean basement, Thunder Bay Pb-Zn-Ba district, Ontario, Canada. Canadian Journal of Earth Sciences, v. 25, pp. 1884-1894.

Hoeve, J., Rawsthorne, K. and Quirt, D. 1981. Uranium metallogenic studies: clay mineral stratigraphy and diagenesis in the Athabasca Group. Saskatchewan Geological Survey, Miscellaneous Report 81-4, pp. 76-89.

Kodama, H., Scott, G.C. and Miles, N.M. 1977. X-ray quantitative analysis of minerals in soils. Agriculture Canada, Soil Research Institute publication, $49 \mathrm{p}$.

Kotzer, T.G., Kyser, T.K. and Irving, E. 1992. Paleomagnetism and the evolution of fluids in the Proterozoic Athabasca Basin, northern Saskatchewan, Canada. Canadian Journal of Earth Sciences, v. 29, pp. 1474-1491.

Kyser, T.K. 1987. Equilibrium fractionation factors for stable isotopes. In: Stable isotope geochemistry of low temperature processes. T.K. Kyser (Ed.). Mineralogical 
Association of Canada, Short Course, v. 13, pp. 1-84.

Lambert, S.J. and Epstein, S. 1980. Stable isotope investigations of an active geothermal system in Valles Caldera, Jemez Mountains, New Mexico. Journal of Volcanology and Geothermal Research, v. 8, pp. 111-129.

Land, L.S. and Dutton, S.P. 1978. Cementation of a Pennsylvanian deltaic sandstone: isotopic data. Journal of Sedimentary Petrology, v. 48, pp. 1167-1176.

Lander, R.H., Bloch, S., Mehta, S. and Atkinson, C.D. 1991. Burial diagenesis of paleosols in the giant Yacheng gas field, People's Republic of China: bearing on illite reaction pathways. Journal of Sedimentary Petrology, v. 61, pp. 256-268.

Lawrence, J.R. and Taylor, H.P. 1971. Deuterium and oxygen-18 correlation: clay minerals and hydroxides in Quaternary soils compared to meteoric waters. Geochimica et Cosmochimica Acta, v. 35, pp. 993-1003.

-.----. 1972. Hydrogen and oxygen isotope systematics in weathering profiles. Geochimica et Cosmochimica Acta, v. 36, pp. 1377-1393.

Lidiak, E.G. and Ceci, V.M. 1991. Authigenic K-feldspar in the Precambrian basement of Ohio and its effect on tectonic discrimination of the granitic rocks. 
Canadian Journal of Earth Sciences, v. 28, pp. 1624-1634.

Longstaffe, F.J. 1987. Stable isotope studies of diagenetic processes. In: Stable isotope geochemistry of low temperature fluids. T.K. Kyser (Ed.). Mineralogical Association of Canada, Short Course, v. 13, pp. 187-257.

Milliken K.L., Land, L.S. and Loucks, R.G. 1981. History of burial diagenesis determined from isotopic geochemistry, Frio Formation, Brazoria County, Texas. The American Association of Petroleum Geologists Bulletin, v. 65, pp. 1397-1413.

Nesbitt, H.W. and Young, G.M. 1989. Formation and diagenesis of weathering profiles. The Journal of Geology, v. 97, pp. 129-147.

O'Neil, J.R. and Kharaka, Y.K. 1976. Hydrogen and oxygen isotope exchange reactions between clay minerals and water. Geochimica et Cosmochimica Acta, v. 40, pp. 241-246.

Pagel, M., Poty, B. and Sheppard, S.M.F. 1980. Contribution to some Saskatchewan uranium deposits mainly from fluid inclusion and isotopic data. In: Uranium in the Pine Creek geosyncline. S. Ferguson and A. Goleby (Eds.). International Atomic Energy Agency, pp. 639-654. 
Retallack, G.J. 1991. Untangling the effects of burial alteration and ancient soil formation. Annual Reviews of Earth and Planetary Science, v. 19, pp. 183-206.

Savin, S.M. and Epstein, S. 1970. The oxygen and hydrogen isotope geochemistry of clay minerals. Geochimica et Cosmochimica Acta, v. 34, pp. 25-42.

Sheppard, S.M.F., Nielsen, R.L. and Taylor, H.P. 1969. Oxygen and hydrogen isotope ratios of clay minerals from porphyry copper deposits. Economic Geology, v. 64, pp. 755-777.

Velbel, M.A. 1985. Basement alteration at unconformities. Geological Society of America, $98^{\text {th }}$ Annual Meeting, Abstracts with Programs, p. 740.

Wilson, M.R. and Kyser, T.K. 1987. Stable isotope geochemistry of alteration associated with the Key Lake uranium deposit, Canada. Economic Geology, v. 82, pp. $1540-1557$.

Yeh, H. and Savin, S.M. 1977. Mechanism of burial metamorphism of argillaceous sediments: 3. O-isotope evidence. Geological Society of America Bulletin, v. 88, pp. 1321-1330.

Yurtsever, Y. and Gat, J.R. 1981. Atmospheric waters. In: Stable isotope hydrology: 


$$
3-2-18
$$

deuterium and oxygen-18 in the water cycle. J.R. Gat and R. Gonfiantini (Eds.). International Atomic Energy Agency, pp. 103-142. 


\section{FIGURE CAPTIONS}

Fig. 3.2.1. Comparison between the $\delta \mathrm{D}$ and $\delta^{18} \mathrm{O}$ values for kaolinite samples from the Thelon Formation sandstone and Thelon paleosol, and the isotopic compositions of kaolinite samples from weathering profiles (Weathering), diagenetically overprinted weathering profiles (Weathering / Diagenesis), and diagenetically altered sandstones (Diagenesis). Numbered references as follows: (1) Savin and Epstein (1970), (2,3) Lawrence and Taylor (1971, 1972), (4) Hassanipak and Eslinger (1985), (5) Wilson and Kyser (1987), (6) Bird and Chivas (1988), (7) Longstaffe (1987), (8) Land and Dutton (1978), (9) Dutton and Land (1985), (10) Milliken et al. (1981).

Fig. 3.2.2. $\delta \mathrm{D}$ and $\delta^{18} \mathrm{O}$ values for kaolinite from the Thelon Formation (triangles, sample numbers 2, 3,4) and Thelon paleosol (circles, sample numbers 5 to 11). Calculated $\delta \mathrm{D}$ and $\delta^{18} \mathrm{O}$ field for 'water' in equilibrium with the kaolinite samples, for $50^{\circ} \mathrm{C}$ formation temperature, is labelled. Also plotted are the $25^{\circ} \mathrm{C}$ kaolinite weathering line, $50^{\circ} \mathrm{C}$ and $100^{\circ} \mathrm{C}$ kaolinite stability lines, the present-day meteoric water line (MWL), and Vienna Standard Mean Ocean Water composition (VSMOW). 


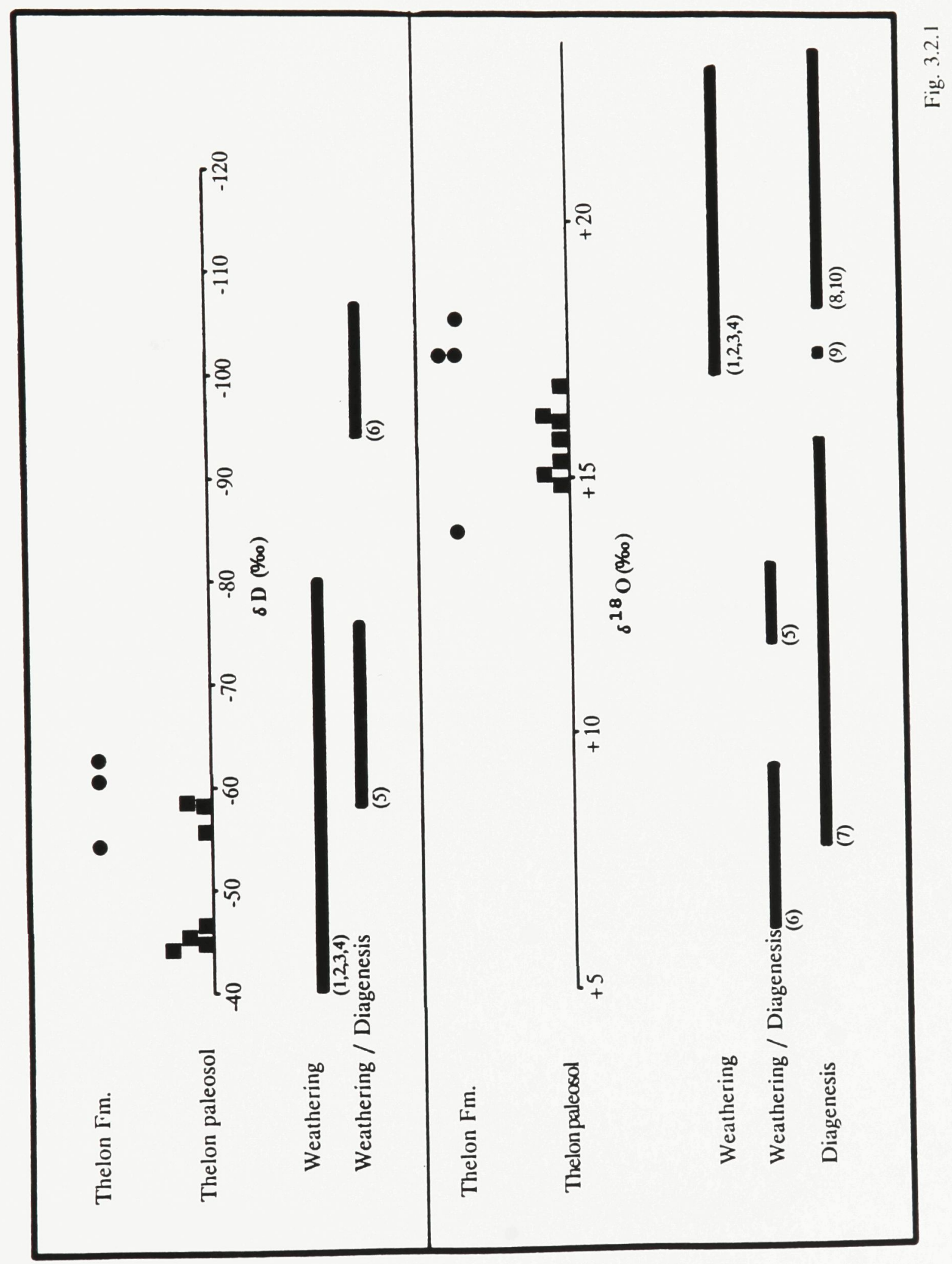




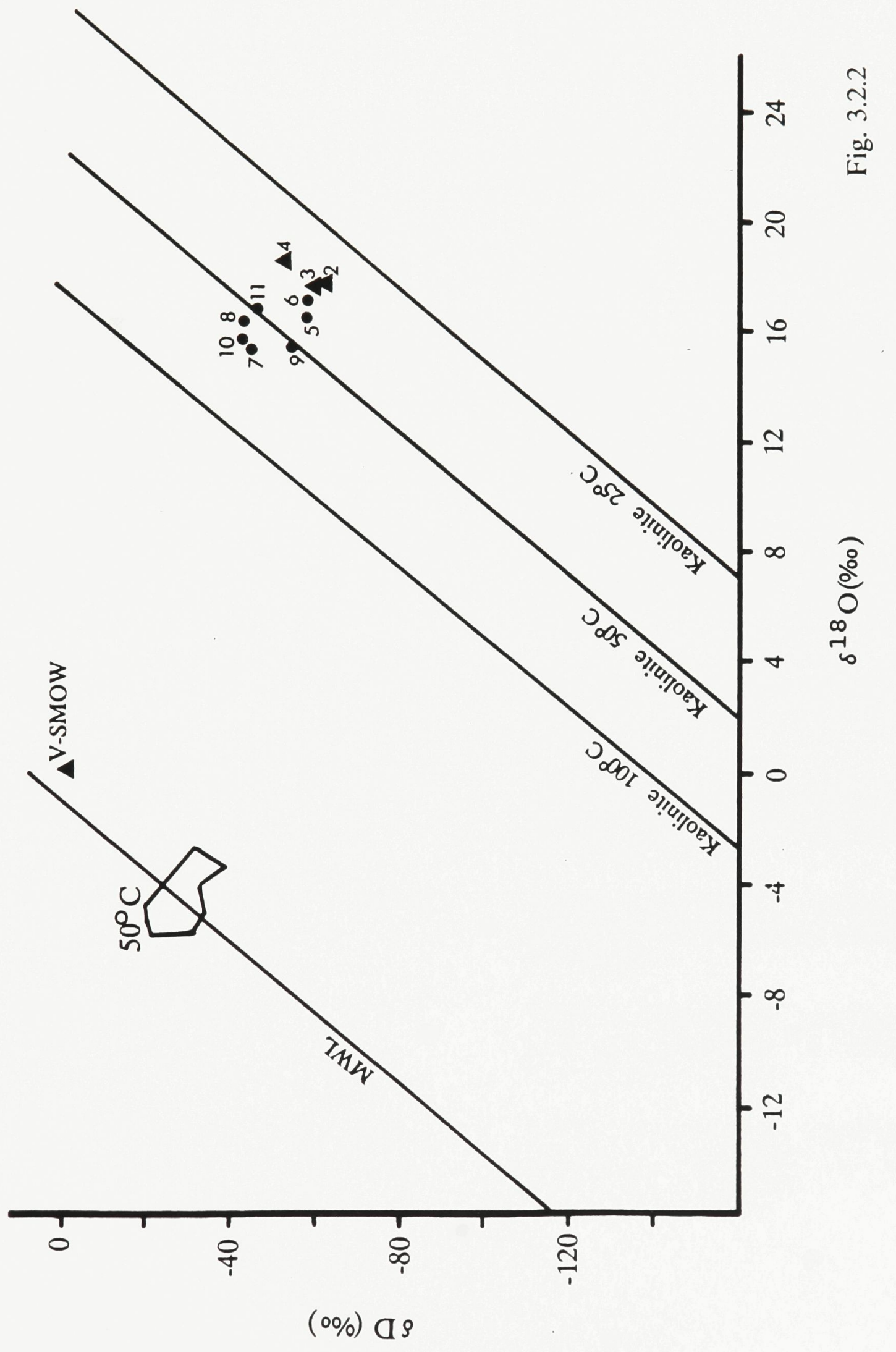


Table 3.2.1 Oxygen $\left(\delta^{18} O\right)$ and hydrogen $(\delta D)$ isotope ana $12 \bar{y}^{2} e^{2}$ for kaolinite, and sample descriptions.

\begin{tabular}{|c|c|c|c|}
\hline Sample & $\delta \mathrm{D} \quad(\%)$ & $\delta^{18} O \quad(\%)$ & Sample description \\
\hline $\begin{array}{l}Q B-1-57 \\
\text { (1) }\end{array}$ & & 13.0 & $\begin{array}{l}\text { Thelon Fm., drill core, } \\
\text { adjacent to Profile } 4 \text { DDH } \\
\text { (Fig. 2.1.1) }\end{array}$ \\
\hline $\begin{array}{l}171-2 B \\
(2)\end{array}$ & -63 & 17.4 & $\begin{array}{l}\text { Thelon Fm., Profile } 1 \\
\text { outcrop (Figs. } 2.1 .1 \text { and } \\
2.2 .1 \text { ) }\end{array}$ \\
\hline $\begin{array}{l}D F-88-1 \\
(3)\end{array}$ & -61 & 17.3 & $\begin{array}{l}\text { Thelon Fm. Profile } 2 \\
\text { outcrop (Figs. } 2.1 .1 \text { and } \\
2.2 .1 \text { ) }\end{array}$ \\
\hline $\begin{array}{l}D F-88-3 \\
(4)\end{array}$ & -54 & 18.0 & $\begin{array}{l}\text { Thelon Fm.' Profile } 2 \\
\text { outcrop (Figs. } 2.1 .1 \text { and } \\
2.2 .1 \text { ) }\end{array}$ \\
\hline $\begin{array}{l}D F-88-4 \\
(5)\end{array}$ & -59 & 16.0 & $\begin{array}{l}\text { Thelon paleosol, Profile } 2 \\
\text { outcrop (Figs. } 2.1 .1 \text { and } \\
2.2 .1 \text { ) }\end{array}$ \\
\hline $\begin{array}{l}D F-88-5 \\
(6)\end{array}$ & -58 & 16.8 & $\begin{array}{l}\text { Thelon paleosol, Profile } 2 \\
\text { outcrop (Figs. } 2.1 .1 \text { and } \\
2.2 .1 \text { ) }\end{array}$ \\
\hline $\begin{array}{l}171-12 \\
(7)\end{array}$ & -45 & 14.9 & $\begin{array}{l}\text { Thelon paleosol, Profile } 1 \\
\text { outcrop (Figs. } 2.1 .1 \text { and } \\
2.2 .1 \text { ) }\end{array}$ \\
\hline $\begin{array}{l}41-1 \\
(8)\end{array}$ & -44 & 15.7 & $\begin{array}{l}\text { Thelon paleosol, outcrop, } \\
\text { Marjorie Hills NTS } 7133500 \mathrm{~N} \\
495250 \mathrm{E}\end{array}$ \\
\hline $\begin{array}{l}94-1 \\
(9)\end{array}$ & -56 & 15.0 & $\begin{array}{l}\text { Thelon paleosol, outcrop, } \\
\text { Marjorie Hills NTS } 7133480 \mathrm{~N} \\
493950 \mathrm{E}\end{array}$ \\
\hline $\begin{array}{l}\text { QG-91-7 } \\
(10)\end{array}$ & -45 & 15.3 & $\begin{array}{l}\text { Thelon paleosol, outcrop, } \\
\text { top of Profile } 2 \text { (Figs. } \\
2.1 .1 \text { and } 2.2 .1 \text { ) }\end{array}$ \\
\hline $\begin{array}{l}Q G-91-19 \\
(11)\end{array}$ & -46 & 16.2 & $\begin{array}{l}\text { Thelon paleosol, outcrop, } \\
\text { west of Dubawnt L. NTS } \\
7040300 \mathrm{~N} 356750 \mathrm{E}\end{array}$ \\
\hline
\end{tabular}


Table 3.2.2 Calculated isotopic compositions of water in equilibrium with kaolinite, using fractionation factors of Lambert and Epstein (1980) and Land and Dutton (1978).

\begin{tabular}{|c|c|c|}
\hline Sample & $\begin{array}{l}\text { a } 50^{\circ} \mathrm{C} \\
\delta \mathrm{D}_{\text {water }}\end{array}$ & $\delta^{18} \mathrm{O}_{\text {water }}$ \\
\hline $171-2 B$ & -39 & -3.7 \\
\hline$D F-88-1$ & -37 & -3.7 \\
\hline$D F-88-3$ & -30 & -3.0 \\
\hline$D F-88-4$ & -35 & -5.0 \\
\hline $\mathrm{DF}-88-5$ & -34 & $-4 \cdot 3$ \\
\hline $171-12$ & -21 & -6.1 \\
\hline $41-1$ & -20 & $-5 \cdot 3$ \\
\hline $94-1$ & -32 & -6.1 \\
\hline$Q G-91-7$ & -21 & -5.8 \\
\hline$Q G-91-19$ & -22 & $-4 \cdot 9$ \\
\hline
\end{tabular}


CHAPTER FOUR

THE EARLY PROTEROZOIC THELON PALEOSOL AS PART OF THE MATONABBEE UNCONFORMITY IN THE NORTHWESTERN CANADIAN SHIELD 


\section{ABSTRACT}

The Thelon paleosol developed on a variety of protoliths after Wharton Group igneous activity, 1760 to $1748 \mathrm{Ma}$, and before $1720 \mathrm{Ma}$ diagenetic formation of apatite in the overlying siliciclastic Thelon Fm. Depending on the protolith, the saprolitic paleosol ranges up to $50 \mathrm{~m}$ thick. Thick profiles have developed where metamorphic fabric in the protolith has allowed deep penetration of the paleoweathering fluids, in contrast to thinner profiles developed on massive igneous protoliths. Where developed on granite, gneiss, schist, rhyolite and peridotite protoliths, the Thelon paleosol is characterised by ascending: (a) protolith disruption, (b) reddening of the paleosol, and (c) increase in mineral dissolution. Geochemically, the Thelon paleosol displays consistent element losses and gains within profiles developed in leucocratic protoliths, but shows inconsistent element behaviour in profiles developed on rhyolite protolith. Analyses of samples from the leucocratic protoliths (normalized to aluminum) show a consistent ascending depletion in $\mathrm{Mg}, \mathrm{Fe}^{2+}, \mathrm{Rb}, \mathrm{K}, \mathrm{Ca}$, a common ascending depletion in $\mathrm{Ti}, \mathrm{Ba}, \mathrm{Na}, \mathrm{Zr}$ and $\mathrm{Mn}$, a consistent ascending addition of $\mathrm{Fe}^{3+}$, and an increase in CIA (chemical index of alteration).

On the basis of gross stratigraphy, paleocurrent data, geochronology, diagenesis in basal basin strata, and similarity in paleosol character, the Thelon paleosol and Thelon Basin strata can be correlated with similar basal paleosols and sedimentary successions within the Athabasca, Hornby Bay and Elu basins in 
the northwestern part of the Canadian Shield. This correlation characterizes the Thelon paleosol as part of the widespread early Proterozoic Matonabbee unconformity. The distribution of paleosols associated with the Matonabbee unconformity delimits areas of relative tectonic stability and subaereal exposure following amalgamation of the early Proterozoic supercontinent Laurentia.

\section{INTRODUCTION}

Within the northwestern part of the Canadian Shield are lower to middle Proterozoic successions of siliciclastic and carbonate sedimentary rocks that comprise the Athabasca, Hornby Bay, Elu, and Thelon basins (Fig. 4.1). Evidence of areally extensive, late early Proterozoic weathering is widespread for most of the underlying Archean and early Proterozoic rocks along the basal unconformity beneath these unmetamorphosed, flat-lying to homoclinal sedimentary successions. Ambrose (1964) was the first to comment on the presence of these paleoweathering zones (paleosols) beneath the Athabasca and Hornby Bay basins, and suggested that they were exhumed remnants of a subaerially weathered Precambrian paleoplain. Since then, little has been published specifically on the paleoweathering beneath these four basins. More has been written on the uranium mineralization spatially associated with the unconformity/paleosol at the base of the basin sequences, particularly in the Athabasca Basin (e.g., Hoeve and Sibbald, 1978; Tremblay, 1983; Hoeve and Quirt, 1984; Wilson and Kyser, 1987) 
and, to a lesser degree, in the Thelon Basin (e.g., Fuchs et al., 1986; Davidson and Gandhi, 1989; Weyer et al., 1989).

This paper describes the Thelon paleosol underlying the Thelon Basin in the Northwest Territories of Canada, briefly describes the paleosols underlying the three other lower to middle Proterozoic basin successions, and presents evidence to support correlation of the paleosols in all four localities. These observations support the existence of an areally widespread paleosurface (now recognized as the Matonabbee unconformity).

\section{THELON PALEOSOL}

The Thelon Basin, which straddles the Mackenzie-Keewatin district boundary in the Northwest Territories of Canada, is composed of an approximately $2 \mathrm{~km}$ thick sequence of flat-lying siliciclastic, volcanic and carbonate strata. The basin succession has been mapped and described by Donaldson (1965; 1969), Cecile (1973) and Gall et al. (1992). At many localities along the basal unconformity to the Thelon Basin a paleosol, here referred to as the Thelon paleosol, has been identified in outcrop and drill core. The Thelon paleosol has developed on variably deformed and metamorphosed Archean and early Proterozoic lithologies, including the unmetamorphosed and little deformed 
ca. 1850 Ma Baker Lake Group and ca. 1760 Ma Wharton Group (Gall et al., 1992). The time of paleoweathering of these units is constrained between the youngest age of the paleoweathered Pitz Formation, $1748 \mathrm{Ma}$ U-Pb zircon age (T.D. Peterson, pers. comm. 1991) from rapikivi granite that is considered to be coeval with Pitz Formation rhyolite, and the youngest date for deposition of the overlying Thelon Formation, $1720+/-6 \mathrm{Ma}$ apatite cement in the Thelon Formation (Miller et al., 1989).

Widespread alteration is considered to have resulted from Proterozoic paleoweathering, rather than epigenetic alteration along the buried sub-Thelon Formation unconformity, for the following reasons: (a) physical and geochemical features outlined by Gall (1992), consistently similar to modern weathering profiles, at or close to the sub-Thelon Formation unconformity; (b) the overlying Thelon Formation contains clasts of altered (paleoweathered) protoliths; (c) alteration associated with the unconformity is preserved in scattered localities spread over hundreds of square kilometres, and only rarely can be related to faulting or epigenetic mineralization; and (d) alteration is present in drill core from areas where the unconformity has never been exhumed (i.e., it is not a product of modern weathering). The Thelon paleosol has been sampled by the author where developed on granite, gneiss, schist, rhyolite, and peridotite. The localities and details for four paleosol profiles developed on leucocratic protoliths are outlined in Gall and Donaldson (1990) and Gall (in review). The following 
description is a recapitulation of the authors' studies of the Thelon paleosol to date.

Both physical and geochemical characteristics have been useful in identifying the Thelon paleosol. Together, physical and geochemical alteration have documented thicknesses of several paleosol profiles in drill core in excess of $50 \mathrm{~m}$. Of the Thelon paleosol profiles which have been studied, the physical characteristics typically predominate higher in the profiles, whereas lower in the profiles, only incipient geochemical alteration of the protolith is evident before descending into fresh protolith. The primary control on Thelon paleosol thickness is the type of protolith: thicker profiles have developed on metamorphosed and deformed rock types; thinner profiles have developed on massive, homogeneous rock types. It appears that the metamorphic fabric has allowed paleoweathering fluids to penetrate to greater depths, resulting in thicker profiles. There are no indications that the extent and thickness of protolith paleoweathering is controlled by any of the other soil-forming factors of Jenny (1941) (i.e., climate, organisms, time, topography).

Gradual ascending disruption of the original protolith textures and structures is the main physical evidence for paleoweathering. Various stages of corestone development (c.f., Ruxton and Berry, 1957) are particularly well developed in the Pitz Formation rhyolite. Augen gneiss also shows a disruption of 
the metamorphic fabric, and development of patchy alteration where some parts of the rock have undergone more intense pedogenic alteration than others. In contrast, massive holocrystalline granite displays only slight textural disruption, locally revealed by angular crystal aggregates separated by minor pedogenic phyllosilicates and hematite. Immediately west of Dubawnt lake, a $20 \mathrm{~cm}$ thick rind of angular, hackly-textured paleoweathered granite can be seen at one locality passing unbroken from a horizontal to a vertical paleojoint surface.

The Thelon paleosol typically shows distinct colour contrast in comparison to adjacent fresh protolith, and to the normally white, grey and red colours of the overlying Thelon Formation. The basal part of the paleosol commonly is grey to green, reflecting the early pedogenic formation of kaolinite and chlorite. Higher in the profiles the paleosol typically is red or reddish-brown, reflecting increasing amounts of pedogenic hematite which developed after the pedogenic phyllosilicates. In some localities the basal Thelon Formation is also red, and it is difficult to distinguish pedogenic hematite from subsequent diagenetic hematite. However, in most localities the basal Thelon Formation is not red, but instead truncates the reddened Thelon paleosol, and may contain hematized pedogenic clasts; this indicates that hematization of the Thelon paleosol occurred before deposition of the Thelon Formation. The paleosol can be distinguished by colour, even where developed on subaerial red rhyolite of the Pitz Formation. Here, paleoweathering has induced subtle red to brown to grey mottling and a general 
lightening in colour of the otherwise dark red- to maroon-coloured fresh rhyolite.

The physical breakdown and discoloration of various protoliths as a result of paleoweathering, ultimately reflects the alteration of original mineralogy and the formation of pedogenic minerals. Where the Thelon paleosol is developed on granitoid, rhyolitic, and pelitic or semipelitic metamorphic protoliths, the feldspars commonly are altered (plagioclase more so than alkali feldspars) to finely divided illite and kaolinite. Quartz is typically unaltered in the paleosol. In the paleoweathered Pitz Formation rhyolite, for example, quartz phenocrysts with distinct resorption outlines occur next to extensively kaolinitized and illitized plagioclase/alkali feldspar phenocrysts. Biotite and hornblende are commonly chloritized and (or) hematized. Hematite occurs in most Thelon paleosol samples, both within grains and interstitially, and everywhere post-dates the kaolinite and some of the illite. Some illites appear to be coarser, perhaps recrystallized, and post-date hematite. Some vermiform pedogenic kaolinite is also pseudomorphosed by coarsely-crystalline illite; some diagenetic kaolinite within the Thelon Formation is also illitized. Some of the more coarsely crystalline illite in the Thelon paleosol, especially where it pseudomorphs kaolinite, probably was produced during diagenesis in the overlying Thelon Formation. Almandine garnet in paleoweathered pelitic gneiss has altered to kaolinite, hematite, and a minor amount of dolomite, and in the paleoweathered Eyeberry Lake peridotite, olivine has been altered to clinochlore (Munro, 1984). 
The Thelon paleosol at Eyeberry Lake has also been cemented by apatite and dolomite during diagenesis of the Thelon Formation. Generally, there is no indication of silcrete associated with the Thelon paleosol (Gall and Donaldson, 1990), as previously suggested by Ross and Chiarenzelli (1985).

Geochemical analyses of the Thelon paleosol samples collected from profiles grading from fresh paleosol protolith up to the overlying Thelon Formation, have been useful in further characterizing the paleosol. Geochemical profile trends are especially consistent where the paleosol is developed on quartzand feldspar-rich (leucocratic) protoliths. The general trend in the Thelon paleosol developed on leucocratic protoliths is essentially one of increasing element depletion as one ascends from fresh protolith to the top of the paleosol. The geochemical data and aluminum-normalized concentration ratio diagrams for four Thelon paleosol profiles developed on leucocratic protoliths are presented in Gall (in review).

Figure 4.2 summarizes these data by depicting whether the major oxides or trace elements show an apparent ascending increase (gain), decrease (loss), or remain unchanged (constant) with respect to $\mathrm{Al}_{2} \mathrm{O}_{3} \quad\left(\mathrm{Al}_{2} \mathrm{O}_{3}\right.$ is considered to have remained relatively immobile during paleoweathering). The presence of stylolites within the paleosol (Gall and Donaldson, 1990) implies paleosol compaction, and negates attempts to quantify these oxide/element trends. The depletion of most 
of the elements within these four profiles is considered to reflect mineral dissolution and element leaching during protolith paleoweathering.

The increase in $\mathrm{Fe}_{2} \mathrm{O}_{3}$ within the profiles likely reflects iron oxidation during paleoweathering. This increase in ferric iron within the Thelon paleosol, together with the depletion of silica in some profiles and the abundance of pedogenic kaolinite, suggest that the paleosol profiles can be classified as Oxisols. Consistent increase in the chemical index of alteration (CIA: Nesbitt and Young, 1982), reflects the pervasive breakdown of feldspars, and mobility of alkali and alkaline earth elements with respect to the relatively immobile aluminum.

Preliminary rare earth element (REE) analyses for Thelon paleosol profiles developed on granite and semipelitic schist show no appreciable REE losses or gains above the granite protolith, but a gain in all REE within the paleosol developed on semipelitic schist. More analyses are forthcoming, but a tentative interpretation of REE gains within the one profile is that the gain is not due to an accumulation of resistant minerals, because most other elements have been depleted or are conserved. Rather, the ascending REE gain above the semipelitic protolith may be caused by adsorption or absorption and concentration of REE on or within the pedogenic minerals, or by precipitation of a REE-bearing mineral in the upper part of the profile during Thelon Formation diagenesis. A diagenetic REE-bearing aluminum phosphate sulphate mineral has recently been 
identified within the same paleoweathered semipelitic schist and overlying Thelon Formation samples that were analysed for REEs.

Geochemical analyses of paleosol profiles developed on Pitz Formation rhyolite are being processed. Preliminary results show anomalous and as yet unexplained increases in $\mathrm{MgO}, \mathrm{TiO}_{2}, \mathrm{P}_{2} \mathrm{O}_{5}, \mathrm{Cr}$ and $\mathrm{Ba}$ within the paleoweathered Pitz Formation samples. Some of the increases may be linked to the persistence of resistant opaque metallic minerals and apatite in the weathered samples.

Subsequent to weathering, the burial by and diagenesis within the Thelon Formation additionally modified the underlying Thelon paleosol. Stylolites within some paleosol samples are interpreted as physical compaction structures developed during deposition of the Thelon Formation, which promoted loading of the structurally weak paleosol. Chemical overprinting of the Thelon paleosol during Thelon Formation diagenesis is considered to have taken place by the downward penetration of diagenetic fluids into the paleosol, as depicted in Fig. 4.3. This phenomenon of alteration (geochemical overprinting) of 'basement' rocks along unconformities by circulating diagenetic fluids has been recognized in Phanerozoic basins by Al-Gailani (1981) and Bethke and Marshak (1990). In the Thelon paleosol, spatially restricted diagenetic overprinting is evident as millimetre-scale veins containing quartz and/or illite that cut across pedogenic minerals. A more pervasive influx of diagenetic fluids into the Thelon paleosol 
during Thelon Formation diagenesis is also evident. This resulted in: (a) dolomite and apatite cementation in the chloritized and illitized peridotite protolith paleosol profile; (b) the formation of illite pseudomorphous after pedogenic, vermiform kaolinite in other paleosol profiles; and (c) anomalous increases in $\mathrm{SiO}_{2}, \mathrm{CaO}, \mathrm{MgO}, \mathrm{P}_{2} \mathrm{O}_{5}$, and $\mathrm{Sr}$ at the top of some Thelon paleosol geochemical profiles.

\section{CORRELATIVE PALEOSOLS}

\section{Sub-Manitou Falls Formation paleosol}

One of the most studied Precambrian paleosols in Canada (Gall, 1992) is the one developed on various Archean and early Proterozoic protoliths in northern Saskatchewan and Alberta, and which is overlain everywhere by siliciclastic sedimentary rocks of the Manitou Falls Formation. The time of formation for this paleosol is constrained using $\mathrm{U}-\mathrm{Pb}$ isotope systematics to be between the ca. 1.82 Ga cooling age for Hudsonian metamorphism (Hoffman, 1988) of paleosol protolith lithologies and a 1700 to 1650 Ma age for diagenetic phosphates within the Athabasca Group (Cummings and Krstic, 1987). Because some of the largest and highest grade uranium deposits in the world are spatially associated with the unconformity/paleosol beneath the Athabasca Basin (Fig. 4.1), most areas in which the paleosol has been documented are in or near zones of 
mineralization. Consequently the paleoweathering signatures commonly are overprinted by mineralization, although this is rarely emphasized or even noted. One notable exception is the thesis study by Macdonald (1980), who described the paleosol in an area free of mineralization.

Perhaps the most striking feature of the paleosol is an ascending colour (mineral) zonation from fresh protolith to grey-green (chloritic) basal paleosol, to white (illitic) paleosol, to a red (hematitic) upper saprolite. This is particularly evident in metasedimentary protoliths (Macdonald, 1980), where the profiles are up to 70 metres thick and include an uppermost bleached zone (attributed to reduction, and/or illite and kaolinite formation during diagenesis in the overlying Athabasca Group). Macdonald has likened these profiles to modern laterites developing in a tropical latitude. Both Macdonald (1980) and Tremblay (1983) noted consistent decreases in $\mathrm{SiO}_{2}, \mathrm{FeO}, \mathrm{CaO}, \mathrm{Na}_{2} \mathrm{O}$, and an increase in $\mathrm{Fe}_{2} \mathrm{O}_{3}$ within the paleosol compared to fresh protolith.

\section{Sub-Hornby Bay Group paleosol}

Along the southern margin of the Hornby Bay Basin, in the Fault River area east of Great Bear Lake (Fig. 4.4), a paleosol developed on volcanic and granitic rocks of the Great Bear Magmatic Zone is overlain by siliciclastic rocks of the Hornby Bay Group. The age of formation for this paleosol is bracketed, 
using U-Pb zircon ages, between the youngest saprolitic granite at ca. $1.85 \mathrm{Ga}$ (Bowring and Van Schmus, 1982), and ca. $1663+/-8 \mathrm{Ma}$, the age of rhyolite porphyry within the Hornby Bay Group (Bowring and Ross, 1985). In the Fault River area, dacite tuffs of the MacTavish Supergroup near the unconformity display enhanced reddening from hematite cementation, and illitization of feldspar phenocrysts. Spheroidal onion-skin weathering of the tuff can be observed at one locality. Unfortunately, fresh volcanic protolith and paleosol samples from the Fault River area did not reveal significant geochemical trends. Perhaps chemical paleoweathering was less intense in this area; or perhaps the paleosol was extensively eroded before deposition of the Hornby Bay Group, so that only the incipient paleoweathering zone, where little chemical change took place, is preserved.

In a few localities within the sub-Hornby Bay Group paleosol, the paleoweathered volcanic protolith is broken into angular pieces separated by dolomite cement. Within a 1-metre interval, the protolith pieces become smaller upward, and increasingly 'float' in the cement before passing into basal dolomitecemented siliciclastic rocks of the Hornby Bay Group. Such compositional and textural relationships are similar to those of the carbonate horizon and k-fabric of Gile et al. (1966). However, due to the presence of similar dolomite cement within the overlying Hornby Bay Group, the carbonate horizon must have developed after deposition of the basal Hornby Bay Group strata, which 
elsewhere in the Fault River area is cemented by quartz. Silcretes within the Hornby Bay Group and paleosol have been described from this area by Ross and Chiarenzelli (1985), but the author has not observed silcrete associated with the sub-Hornby Bay Group paleosol in the Fault River area. A few kilometres to the east of the area shown in figure 4.4, paleoweathered granite also displays reddening from hematization, illitization of feldspars, and chloritization of biotite. However, the paleoweathered granite samples come from an area where unconformity-related U-PGE-Au mineralization occurs (Gandhi and Paktunc, 1989), and the extent to which alteration might be related to mineralization is not clear.

\section{Sub-Ellice Formation paleosol}

Campbell (1979) briefly described a paleosol developed on Archean and Tinney Cove Formation protolith beneath the Ellice Formation along the southern margin of the Elu Basin (Fig. 4.1) at Elu Inlet in the Northwest Territories.

Geochronologic constraints on the development of this paleosol are lacking, although stratigraphic correlations between the Hornby Bay Basin and Elu Basin by Fraser et al. (1970) and Kerans et al. (1981), suggest that the paleosol underlying the two basins can be correlated. A paleoweathered granite from near Ovayor Hill in Elu Inlet (Fig. 4.5) displays surface-parallel 
paleoweathering rinds, illitization of feldspars, and late-stage reddening from disseminated hematite. Compared to Archean granite protolith, geochemical analyses from this locality (Table 4.1) show a slight decrease in $\mathrm{SiO}_{2}, \mathrm{TiO}_{2}$, $\mathrm{Fe}_{2} \mathrm{O}_{3}$ (total), $\mathrm{MgO}, \mathrm{Zn}, \mathrm{Zr}$ and $\mathrm{Sr}$, and a slight increase in $\mathrm{K}_{2} \mathrm{O}$ and $\mathrm{P}_{2} \mathrm{O}_{5}$, within the paleosol.

\section{INTERBASIN CORRELATION AND THE MATONABBEE UNCONFORMITY}

Summarized in figure 4.6 are stratigraphic and geochronologic data for the Thelon, Athabasca, Hornby Bay and Elu basins, and the stratigraphic position of the Matonabbee unconformity with its concomitant paleosols. These four undeformed and unmetamorphosed early- to middle-Proterozoic age basin sequences have been correlated by Donaldson (1967) and Fraser et al. (1970) based on gross stratigraphy, paleocurrents and some geochronology. Further studies of stromatolite morphology (J.A. Donaldson, pers. comm. 1990) within the successions, similarities in diagenetic sequences (quartz - phyllosilicates phosphates - hematite) within the basal siliciclastic units in all four basins (Cecile, 1973; Hoeve and Quirt, 1984; Wilson, 1985; Gall, in review; unpublished data of Gall), uranium and precious metal mineralization spatially associated with the basal unconformities/paleosols (Nash et al., 1981; Roscoe, 1984; Miller and LeCheminant, 1985; Roscoe et al., 1986; Davidson and Gandhi, 1989; Gandhi and 
Pactunc, 1989), further age determinations of paleosol protolith and basin strata, and the physical and chemical features of the paleosols beneath the four basin sequences (as summarized); all reinforce the correlation first proposed by Donaldson (1967), and suggest that the Thelon, sub-Manitou Falls Formation, sub-Hornby Bay Group and sub-Ellice Formation paleosols are coeval and part of the Matonabbee unconformity (Gall and Donaldson, 1990a; Gall, 1992). The formation of the Matonabbee erosion surface and paleosols was likely diachronous; the best available time constraint for the development of the Matonabbee paleosurface comes from the Thelon area (Fig. 4.6), which suggests that it formed about 1.74 Ga ago.

The direction of paleocurrent transport for the siliciclastic sediments overlying the paleosols in all four basins was generally west to southwest; significantly, the paleocurrent trends are not deflected near the present basin margins and do not show a centripetal distribution about the basin margins. These features, together with the correlations mentioned above, suggest that the four basin sequences are remnants of a more extensive sedimentary sequence which covered a deeply weathered, ca. 1.74 Ga erosion surface. In a tectonostratigraphic context, development of a paleosol over such a large area is exactly what would be expected on a relatively stable craton following amalgamation of Archean and early Proterozoic crust, resulting in the formation of the supercontinent Laurentia between 1.9 and 1.7 Ga, as described by Hoffman 
(1989). Paleomagnetic data for rocks in the northwestern Canadian Shield for this time interval (Donaldson et al., 1973; Park et al., 1973; Kotzer et al., 1992), including some paleoweathered rocks, indicate that their formation and subsequent paleoweathering took place at low to mid paleolatitudes.

\section{CONCLUSION}

The Thelon paleosol displays a number of consistent physical and geochemical features, on a variety of protoliths distributed over a wide area, suggesting that it represents a widespread saprolitic Oxisol which formed approximately $1.74 \mathrm{Ga}$ ago. Paleosols immediately underlying the Athabasca, Hornby Bay and Elu basins display similar physical and geochemical features to the Thelon paleosol. Important geochronological constraints on the time of paleosol development, and similarities between stratigraphic successions within the overlying basins, all indicate that these paleosols are remnants of a regional paleoweathering surface, now known as the Matonabbee unconformity. The presence of many widely distributed coeval paleosols indicates that all, or parts of, Laurentia in the northwestern Canadian Shield attained relative tectonic stability and subaerial exposure subsequent to supercontinent amalgamation. 
The author would like to thank J.A. Donaldson (Carleton University, Ottawa) and M. Pagel (CREGU, Nancy-Vandoeuvre) for thorough and constructive reviews of earlier versions of this paper. 


\section{REFERENCES}

Al-Gailani, M.B. 1981.

Authigenic mineralizations at unconformities: implication for reservoir characteristics. Sedimentary Geology, v. 29, pp. 89-115.

Ambrose, J.W. 1964.

Exhumed paleoplains of the Precambrian shield of North America. American Journal of Science, v. 262, pp. 817-857.

Bethke C.M. and Marshak, S. 1990.

Brine migration across North America - the plate tectonics of groundwater.

Annual Review of Earth and Planetary Sciences, v. 18, pp. 287-315.

Bowring, S.A. and Ross, G.M. 1985.

Geochronology of the Narakay volcanic complex: implications for the age of the

Coppermine Homocline and Mackenzie igneous event. Canadian Journal of Earth Sciences, v. 22, pp. 774-781.

Bowring, S.A. and Van Schmus, W.R. 1982.

Age and duration of igneous events, Wopmay Orogen, Northwest Territories,

Canada. Geological Society of America, Abstracts with Programs, v. 14, p. 449. 
Campbell, F.H.A. 1979.

Stratigraphy and sedimentation in the Helikian Elu Basin and Hiukituk platform, Bathurst Inlet - Melville Sound, Northwest Territories. Geological Survey of Canada, Paper 79-8, 18 p.

Cecile, M.P. 1973.

Lithofacies analysis of the Proterozoic Thelon Formation, Northwest Territories. M.Sc. thesis, Carleton University, Ottawa, 119 p.

Cumming, G.L. and Krstic, D. 1987.

Age of the Athabasca Group, northern Alberta. Geological Association of Canada and Mineralogical Association of Canada, Program with Abstracts, v. 12, p. 35 .

Davidson, G.I. and Gandhi, S.S. 1989.

Unconformity-related U-Au mineralization in the Middle Proterozoic Thelon sandstone, Boomerang Lake prospect, Northwest Territories, Canada. Economic Geology, v. 84, pp. 143-157.

Donaldson, J.A. 1965.

The Dubawnt Group, District of Keewatin and Mackenzie. Geological Survey of Canada, Paper 64-20, 11 p. 
1967.

Two Proterozoic clastic sequences: a sedimentological comparison. Geological Association of Canada, Proceedings, v. 18, pp. 33-54.

1969.

Descriptive notes (with particular reference to the Late Proterozoic Dubawnt Group) to accompany a geological map of central Thelon Plain, Districts of Keewatin and Mackenzie. Geological Survey of Canada, Paper 68-49, 4 p.

Donaldson, J.A., McGlynn, J.C., Irving, E. and Park, J.K. 1973.

Drift of the Canadian Shield. In: Implications of continental drift to the Earth sciences. D.H. Tarling and S.K. Runcorn (Eds.). Academic Press, pp. 3-17.

Fraser, J.A., Donaldson, J.A., Fahrig, W.F. and Tremblay, L.P. 1970.

Helikian basins and geosynclines of the northwestern Canadian Shield.

Geological Survey of Canada, Paper 70-40, pp. 213-238.

Fuchs, H.D., Hilger, W. and Prosser, E. 1986.

Geology and exploration history of the Lone Gull property. Canadian Institute of Mining and Metallurgy, Special Volume 33, pp. 286-292.

Gall, Q. 1992. 
Precambrian paleosol in Canada. Canadian Journal of Earth Sciences, v. 29, pp. 2530-2536.

in review.

The Proterozoic Thelon paleosol, Northwest Territories, Canada. Precambrian Research.

Gall, Q. and Donaldson, J.A. 1990.

The sub-Thelon Formation paleosol, Northwest Territories. Geological Survey of Canada, Paper 90-1C, pp. 271-277.

------ 1990a.

The sub-Thelon Formation paleosol, and its correlation with similar paleosols in the northwestern part of the Canadian Shield. Geological Association of Canada and Mineralogical Association of Canada Annual Meeting, Program with Abstracts, v. 15, p. A43.

Gall, Q., Peterson, T.D. and Donaldson, J.A. 1992.

A proposed revision of Early Proterozoic stratigraphy of the Thelon and Baker Lake basins, Northwest Territories. Geological Survey of Canada, Paper 92-1C, pp. 129-137. 
Gandhi, S.S. and Paktunc, A.D. 1989.

$\mathrm{Au}, \mathrm{Pt}$, and $\mathrm{Pd}$ in pitchblende and copper sulphide veins at the Rah, Far, and Jaciar prospects, northern Bear Province, Northwest Territories. Geological Survey of Canada, Paper 89-1C, pp. 243-253.

Gile, L.H., Peterson, F.F. and Grossman, R.B. 1966.

Morphological and genetic sequences of carbonate accumulation in desert soils. Soil Science, v. 101, pp. 347-360.

Hoeve, J. and Quirt, D. 1984.

Uranium mineralization and host rock alteration to clay mineral diagenesis and evolution of the Middle Proterozoic Athabasca Basin, Saskatchewan.

Saskatchewan Research Council, Publication R-855-2-B-84, 190 p.

Hoeve, J. and Sibbald, T.I.I. 1978.

On the genesis of Rabbit Lake and other unconformity-type uranium deposits in northern Saskatchewan, Canada. Economic Geology, v. 73, pp. 1450-1473.

Hoffman, P.F. 1988.

United plates of America, the birth of a craton; early Proterozoic assembly and growth of Laurentia. Annual Reviews of Earth and Planetary Sciences, v. 16, pp. 543-603. 
1989.

Precambrian geology and tectonic history of North America. In: The geology of North America Volume A, The geology of North America - an overview. A.W. Bally and A.R. Palmer (Eds.), Geological Society of America, pp. 447-512.

Jenny, H. 1941.

Factors of soil formation. McGraw-Hill, $281 \mathrm{p}$.

Kerans, C., Ross, G.M., Donaldson, J.A. and Geldsetzer, H.J. 1981.

Tectonism and depositional history of the Helikian Hornby Bay and Dismal Lakes groups, District of Mackenzie. Geological Survey of Canada, Paper 81-10, pp. $157-182$.

Kotzer, T.G., Kyser, T.K. and Irving, E. 1992. Paleomagnetism and the evolution of fluids in the Proterozoic Athabasca Basin, northern Saskatchewan, Canada. Canadian Journal of Earth Sciences, v. 29, pp. 1474-1491.

Macdonald, C. 1980.

Mineralogy and geochemistry of Precambrian regolith in the Athabasca Basin. M.Sc. thesis, University of Saskatchewan, Saskatoon, $161 \mathrm{p}$.

Miller, A.R. and LeCheminant, A.N. 1985. 
Geology and uranium metallogeny of Proterozoic supracrustal successions, central

District of Keewatin, N.W.T. with comparisons to northern Saskatchewan.

Canadian Institute of Mining and Metallurgy, Special Paper 32, pp. 167-185.

Miller, A.R., Cumming, G.L. and Krstic, D. 1989.

$\mathrm{U}-\mathrm{Pb}, \mathrm{Pb}-\mathrm{Pb}$, and $\mathrm{K}-\mathrm{Ar}$ isotopic study and petrography of uraniferous phosphatebearing rocks in the Thelon Formation, Dubawnt Group, Northwest Territories, Canada. Canadian Journal of Earth Sciences, v. 26, pp. 867-880.

Munro, K.A. 1984.

Possible regolith beneath Proterozoic sandstones of the Thelon Formation, Northwest Territories. B.Sc. thesis, Carleton University, Ottawa, 40 p.

Nash, J.Y., Granger, H.C. and Adams, S.S. 1981.

Geology and concepts of genesis important types of uranium deposits. Economic Geology, 75th Anniversary Volume, pp. 63-116.

Nesbitt, H.W. and Young, G.M. 1982.

Early Proterozoic climates and plate motion inferred from major element chemistry of lutites. Nature, v. 299, pp. 715-717.

Park, J.K., Irving, E. and Donaldson, J.A. 1973. 
Paleomagnetism of the Precambrian Dubawnt Group. Geological Society of America Bulletin, v. 84, pp. 859-870.

Roscoe, S.M. 1984.

Assessment of mineral resource potential in the Bathurst Inlet-area, NTS 76J, K, $\mathrm{N}$, O including the proposed Bathurst Inlet National Park. Geological Survey of Canada, Open File 788, 75 p.

Roscoe, S.M., Green, S.B. and Gandhi, S.S. 1986.

Uranium, gold and selenide minerals locally concentrated in drift at 'Twin Lakes' near Bathurst Inlet, N.W.T. Geological Survey of Canada, Paper 86-1B, pp. 47-56.

Ross, G.M. and Chiarenzelli, J.R. 1985.

Paleoclimatic significance of widespread Proterozoic silcrete in the Bear and Churchill provinces of the northwestern Canadian Shield. Journal of Sedimentary Petrology, v. 55, pp. 196-204.

Ruxton, B.P. and Berry, L. 1957.

Weathering of granite and associated erosional features in Hong Kong. Bulletin of the Geological Society of America, v. 68, pp. 1263-1292.

Tremblay, L.P. 1983. 
Some chemical aspects of the regolithic and hydrothermal alterations associated with the uranium mineralization in the Athabasca Basin, Saskatchewan. Geological Survey of Canada, Paper 83-1A, pp. 1-14.

Weyer, H. J.-, Friedrich, G., Bechtel, A. and Ballhorn, R.K. 1989.

The Lone Gull uranium deposit - new geochemical and petrological data as evidence for the nature of the ore bearing solutions. In: Metallogenesis of uranium deposits. International Atomic Energy Agency, TC 542, pp. 293-306.

Wilson, J.A. 1985.

Geology of the Athabasca Group in Alberta. Alberta Research Council, Bulletin $49,47 \mathrm{p}$.

Wilson, M.R. and Kyser, T.K. 1987

Stable isotope geochemistry of alteration associated with the Key Lake uranium deposit, Canada. Economic Geology, v. 82, pp. 1540-1557. 


\section{CAPTIONS}

Fig. 4.1 The distribution of the Thelon, Athabasca, Hornby Bay and Elu basins (black areas) in the northwestern part of the Canadian Shield.

Fig. 4.2 Summary of ascending geochemical trends in four Thelon paleosol profiles developed on leucocratic protoliths, depicting whether major oxides or trace elements have increased (gain), decreased (loss), or remained unchanged (constant) within the paleosol compared to the unweathered protolith. NA $=$ not analysed.

Fig. 4.3 Schematic diagram depicting movement (arrows) of meteoric fluids during pedogenesis and, following deposition of the Thelon Formation, the movement (arrows) of Si-, Fe-, K-, Ca-, Mg-, P-, and Sr-bearing diagenetic fluids into the top of the Thelon paleosol.

Fig. 4.4 Geology and sub-Hornby Bay Group paleosol localities in the Fault River area, Northwest Territories.

Fig. 4.5 Geology and sub-Ellice Formation paleosol localities near Ovayor Hill, Elu Inlet, Northwest Territories. 
Fig. 4.6 Correlation of strata in four early- to middle-Proterozoic basins in the northwestern Canadian Shield, utilizing the Matonabbee unconformity and attendant paleosols as a datum. The ages shown (in Ma) were obtained from volcanic rocks $(\mathrm{V})$ or phosphate cement $(\mathrm{P})$. Generalized paleocurrent trends (black sector of circles) are adjacent to the pertinent units. 


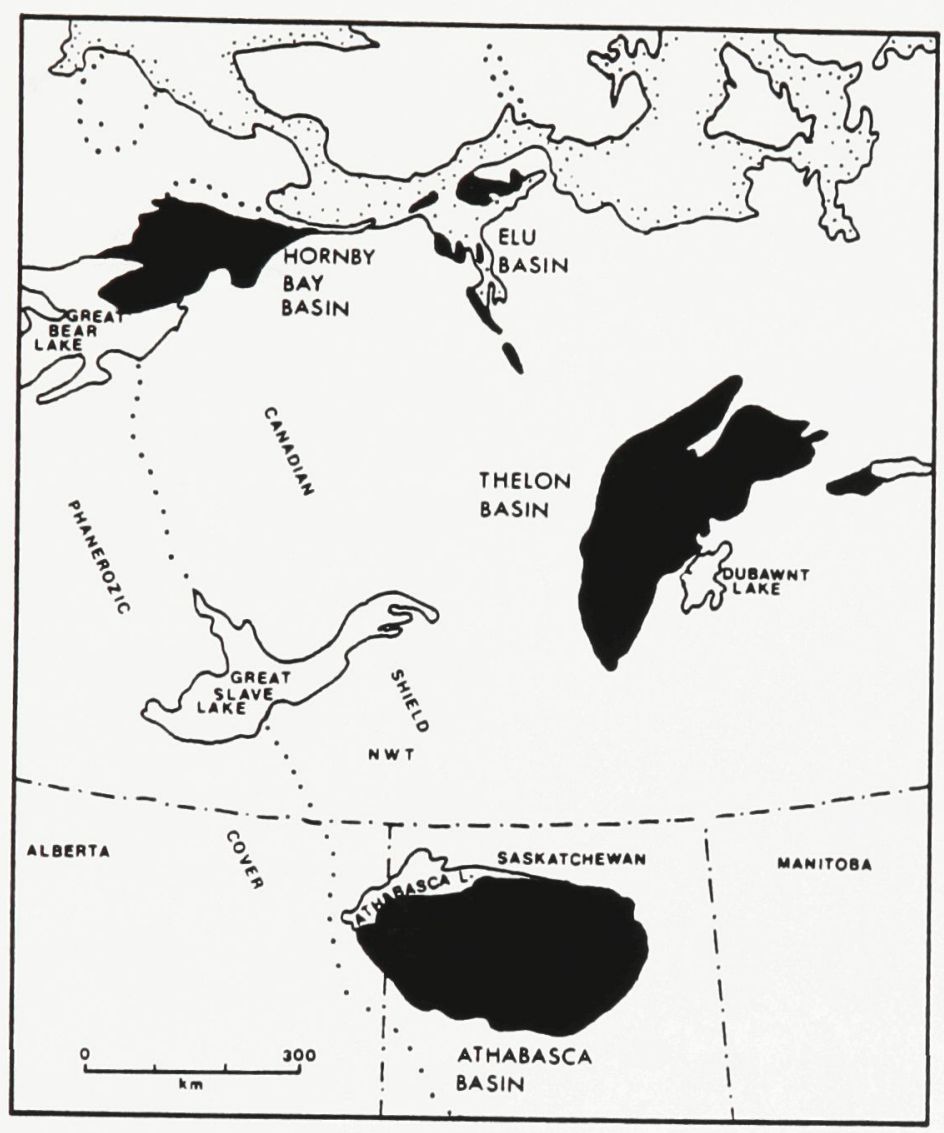

Fig. 4.1 


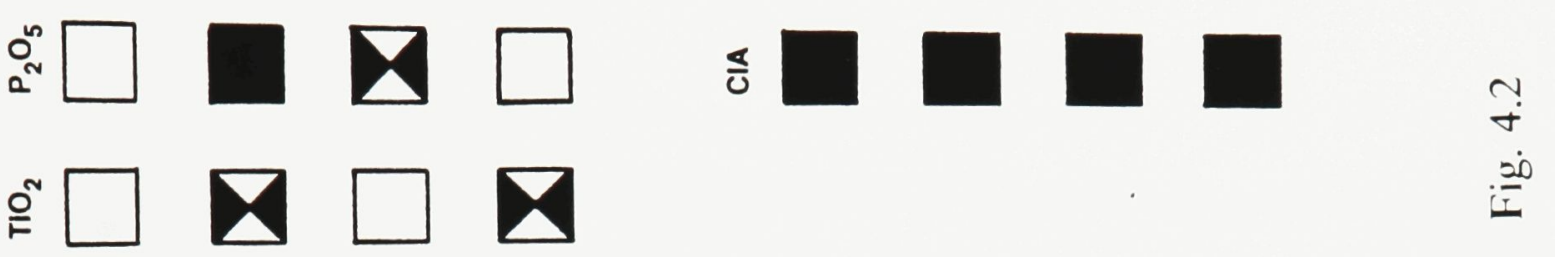

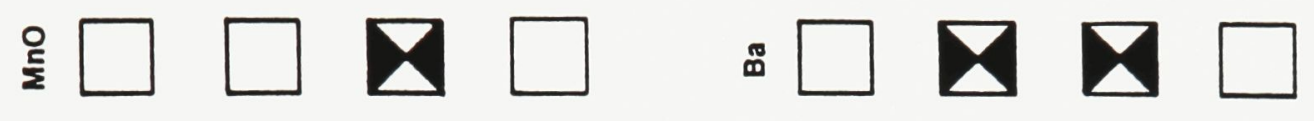

@ $\square \mathbf{\square} \square$ ‘ $\square \mathbf{\square \square} \square$

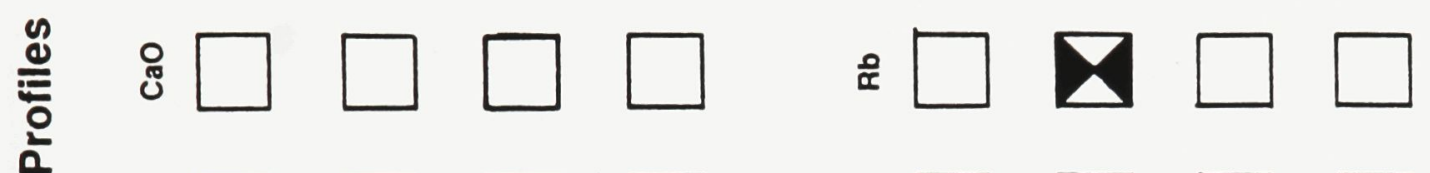

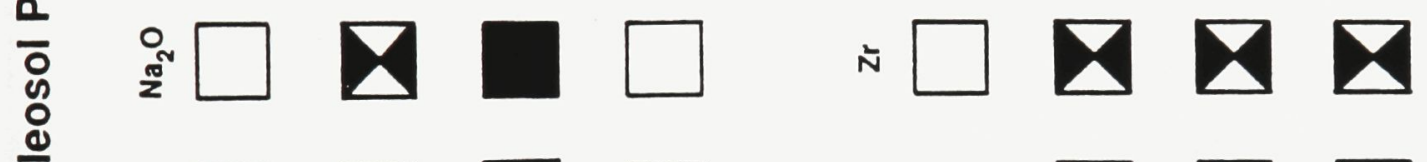

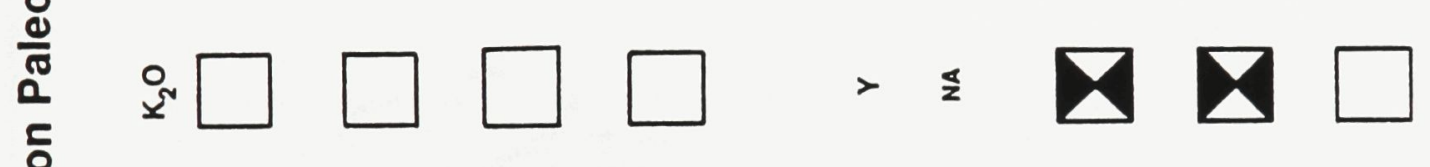

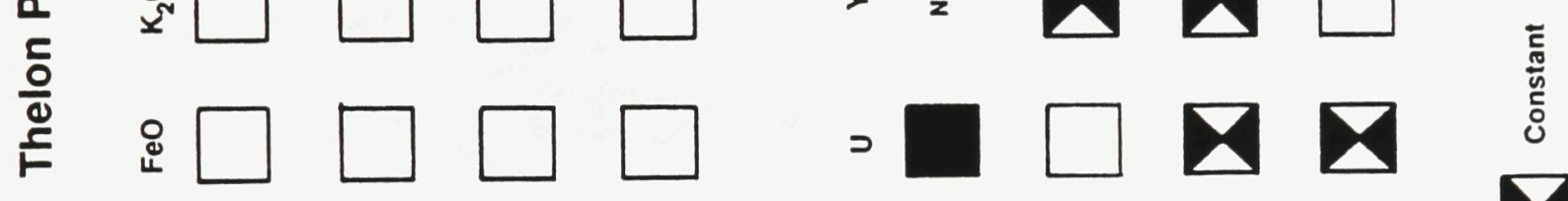

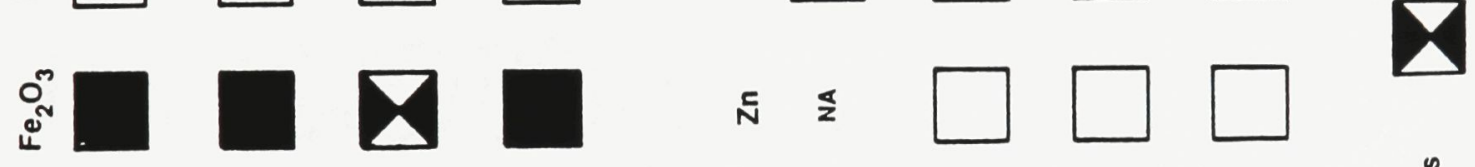

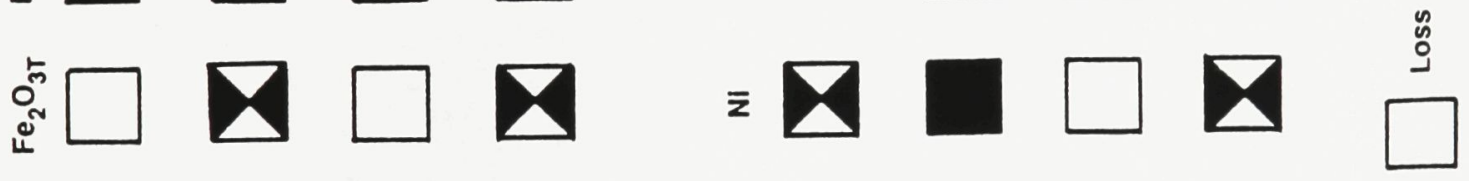

要

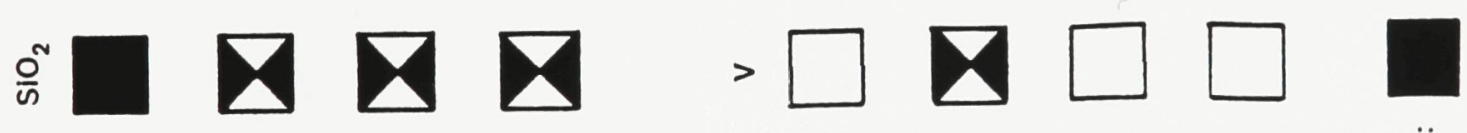

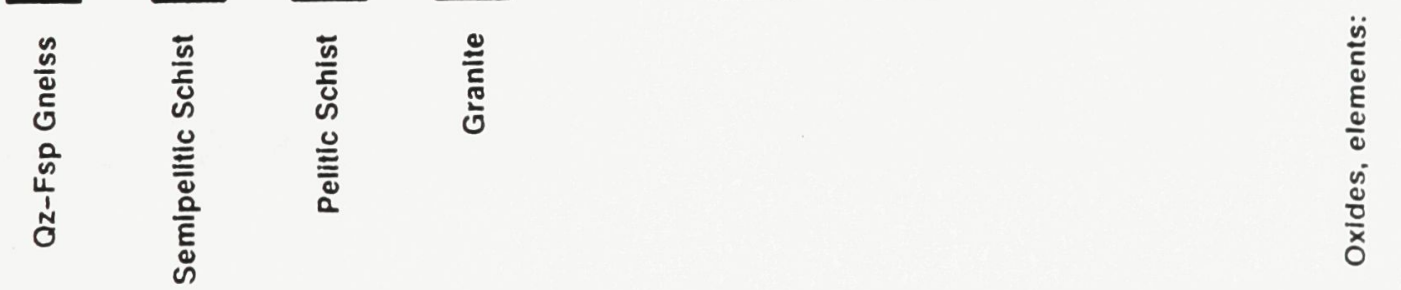

sul!10101d 


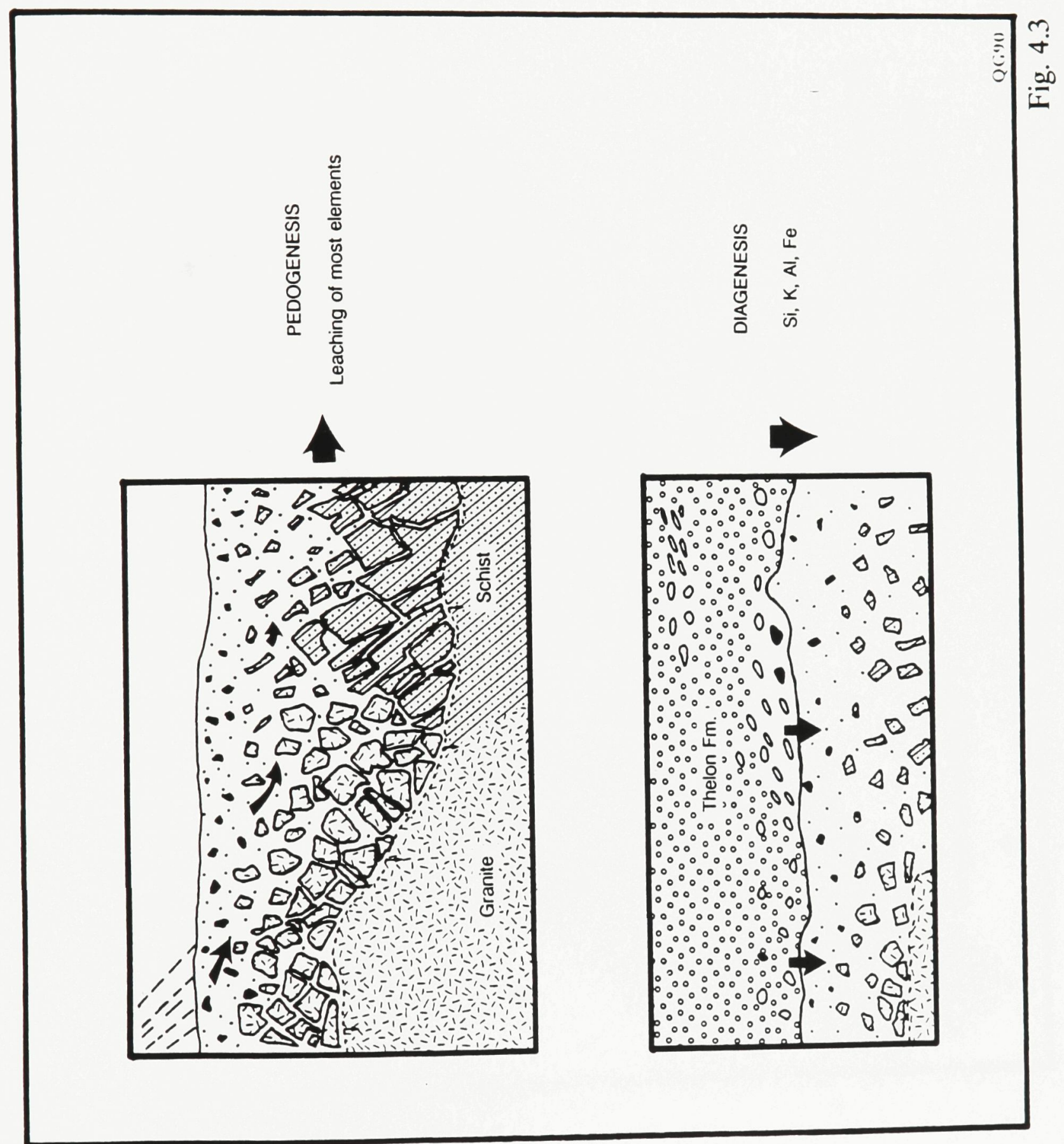




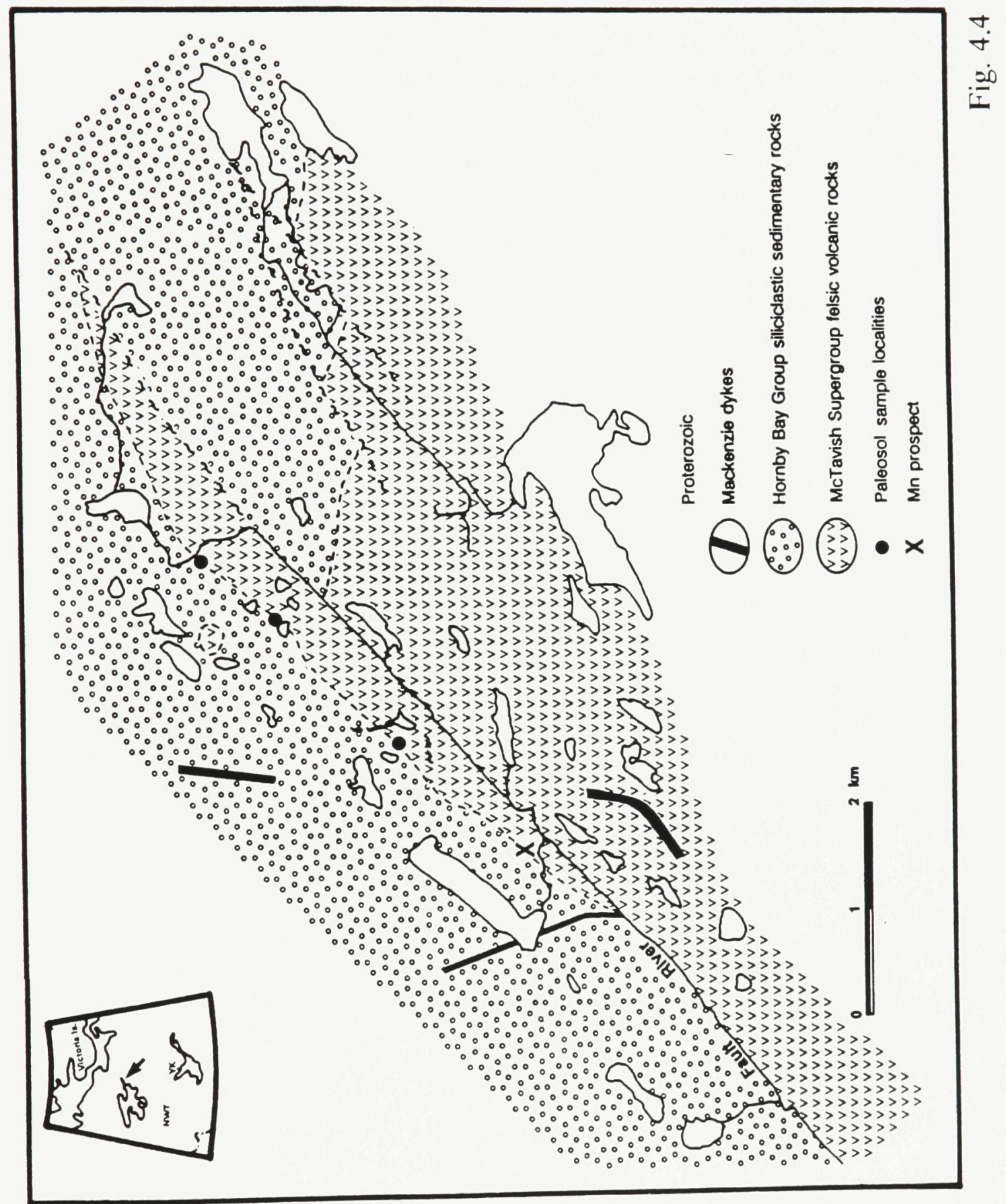




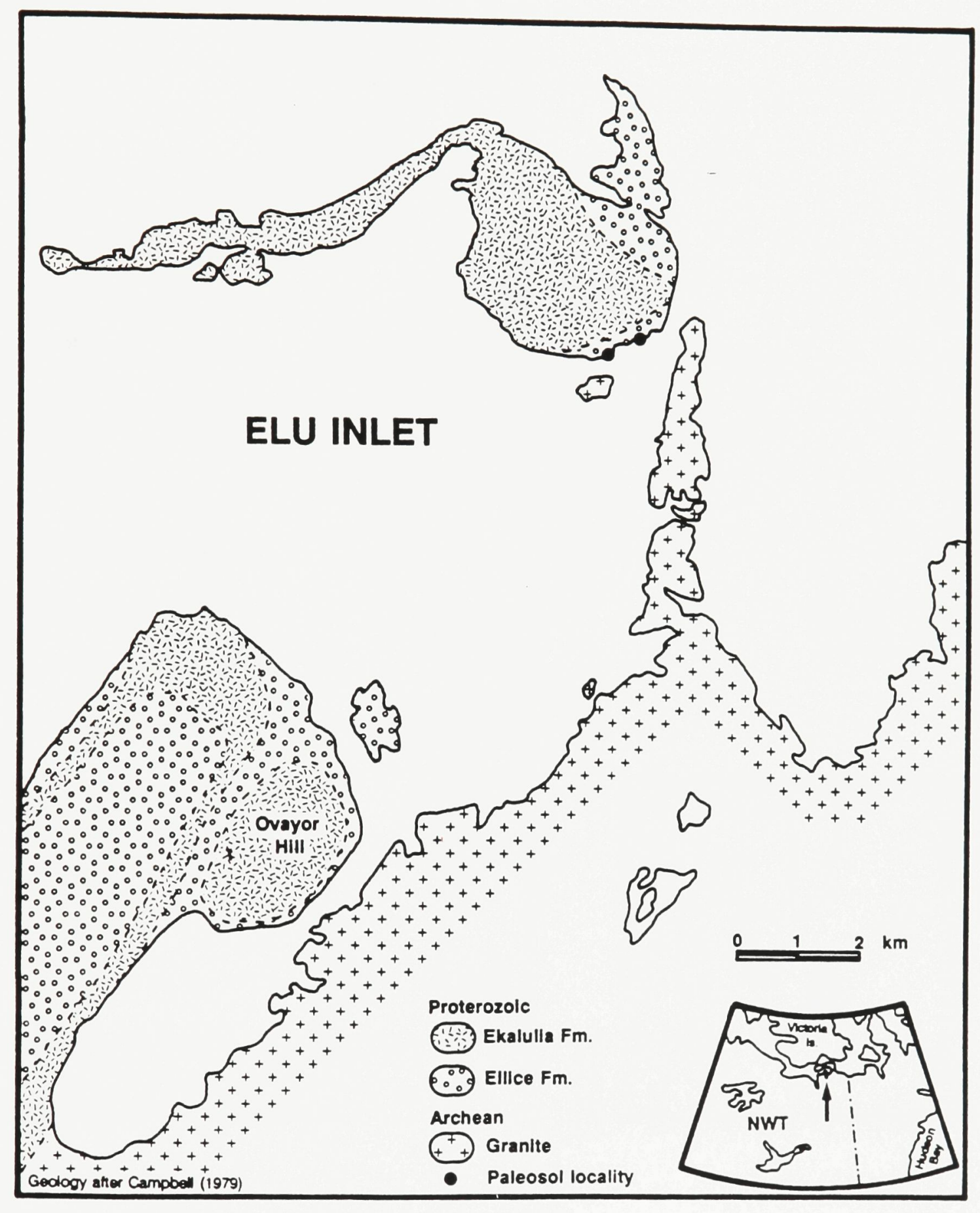

Fig. 4.5 


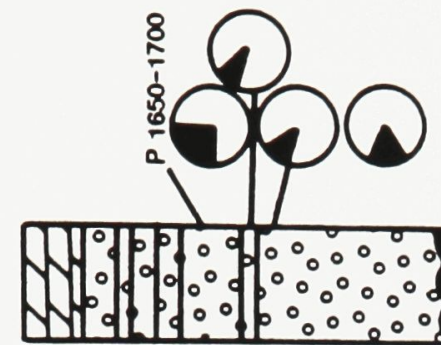

$4-36$

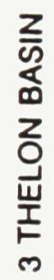

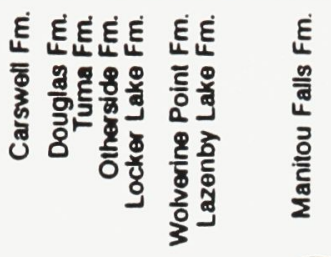

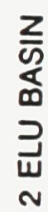

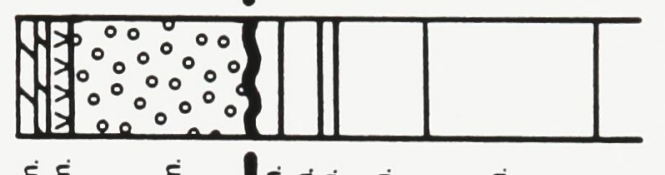

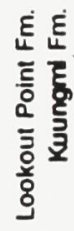

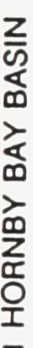
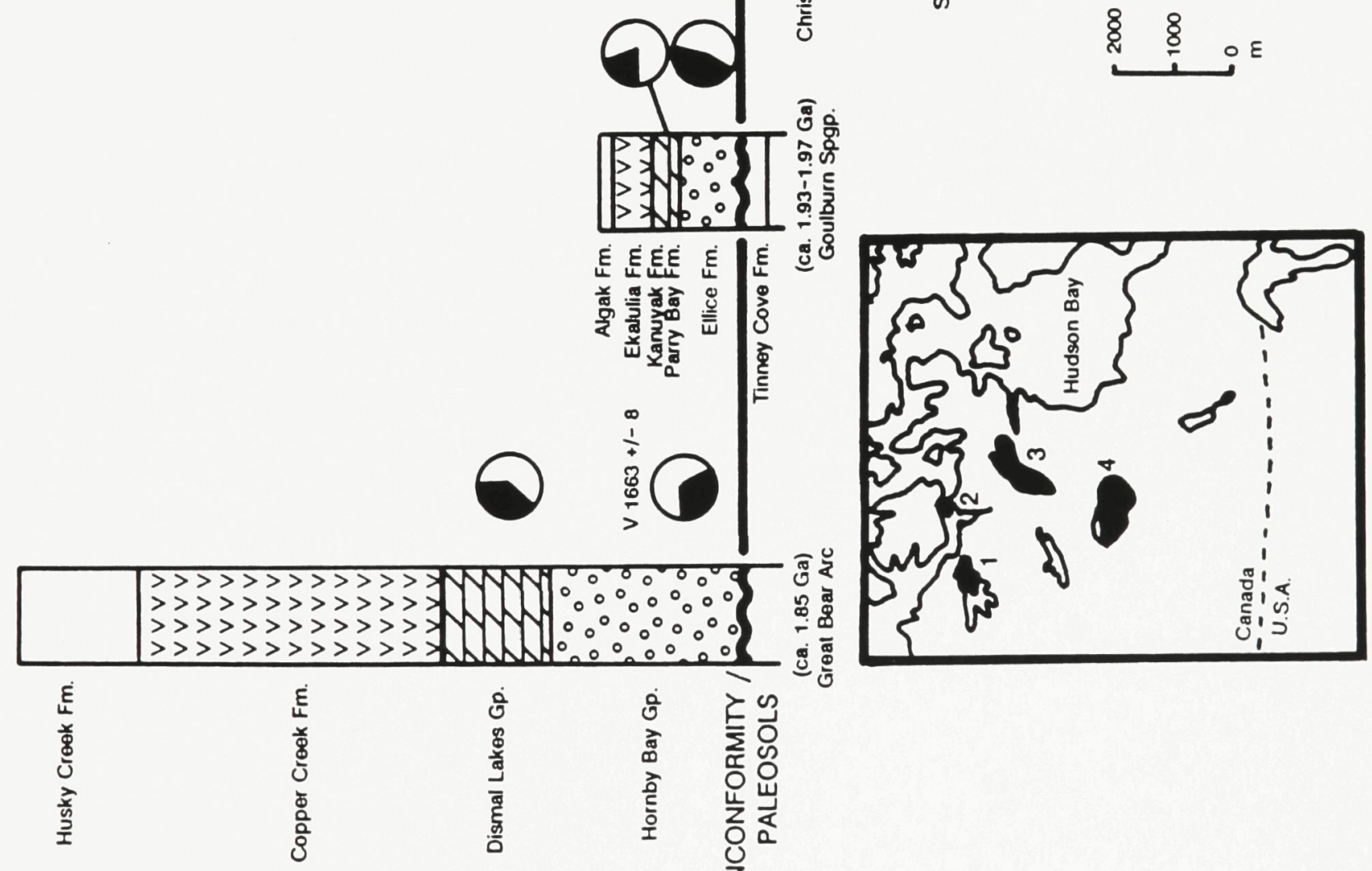

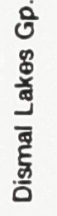

尼

帘 
Table 4.1. Sub-Ellice Formation paleosol profile geochemistry from an island north of Ovayor Hill in Elu Inlet (see Fig. 4.5).

\begin{tabular}{lcccc} 
Sample: & JG-1 & JG-3 & JG-2 & JG-4 \\
\hline Lithology: & granite & paleosol & paleosol & Ellice Fm. \\
\hline \multicolumn{5}{c}{ Wt. $\%$} \\
$\mathrm{SiO}_{2}$ & 69.92 & 68.25 & 63.79 & 96.68 \\
$\mathrm{AL}_{2} \mathrm{O}_{3}$ & 15.66 & 15.75 & 18.50 & 1.33 \\
$\mathrm{TiO}_{2}$ & 0.28 & 0.26 & 0.04 & 0.03 \\
$\mathrm{Fe}_{2} \mathrm{~T}$ & 2.93 & 2.76 & 1.19 & 0.42 \\
$\mathrm{Fe}_{2} \mathrm{O}_{3}$ & 0.90 & 1.19 & 0.53 & 0.00 \\
$\mathrm{FeO}_{\mathrm{O} O}$ & 1.83 & 1.42 & 0.60 & 0.83 \\
$\mathrm{MnO}$ & 0.03 & 0.02 & 0.01 & 0.01 \\
$\mathrm{MgO}$ & 1.01 & 1.47 & 0.30 & 0.05 \\
$\mathrm{CaO}$ & 1.78 & 0.47 & 0.40 & 0.03 \\
$\mathrm{Na} \mathrm{O}_{2} \mathrm{O}$ & 3.85 & 1.21 & 2.99 & 0.10 \\
$\mathrm{~K}_{2} \mathrm{O}$ & 3.33 & 7.57 & 11.11 & 0.37 \\
$\mathrm{P}_{2} \mathrm{O}_{5}$ & 0.08 & 0.02 & 0.11 & 0.01 \\
& & & $p p m$ & \\
$\mathrm{~V}$ & 0 & 6 & 2 & 0 \\
$\mathrm{Cr}$ & 35 & 40 & 34 & 52 \\
$\mathrm{Ni}$ & 25 & 19 & 18 & 19 \\
$\mathrm{Zn}$ & 50 & 35 & 7 & 12 \\
$\mathrm{Y}$ & 2 & 4 & 9 & 3 \\
$\mathrm{Zr}$ & 125 & 117 & 72 & 54 \\
$\mathrm{Rb}$ & 61 & 107 & 84 & 0 \\
$\mathrm{Sr}$ & 314 & 102 & 61 & 0 \\
$\mathrm{Ba}$ & 381 & 429 & 277 & 37
\end{tabular}


$-$ 


\section{$\underline{X-R a y ~ D i f f r a c t o m e t r y ~}$}

Sample Preparation -

(Dept. of Geography, Carleton Univ.)

Sand-size fragments of each sample were sonicated in distilled water, using $1 \%$ sodium hexametaphosphate as a dispersant. The suspension was decanted, and allowed to stand for 4 hrs. This second suspension was decanted into centrifuge tubes, and $4 \mathrm{ml} 1 \mathrm{~N} \mathrm{MgCl}_{2}$ was added to each tube. These tubes were centrifuged at $2000 \mathrm{rpm}$ for $20 \mathrm{~min}$. The suspension was decanted, leaving a residue of clayfraction sediment.

Oriented clay-fraction mounts were made for each sample, and scanned by X-ray diffraction. Some samples were heat treated to distinguish chlorite from kaolinite diffractogram peaks, and/or glycolated, to determine the presence of 'swelling' phyllosilicates.

Heat treatment - sample slides were oven-heated at $550^{\circ} \mathrm{C}$ for $1 \mathrm{hr}$.

Glycolation - sample slides were placed on a tray for 24 hrs in a bell jar containing sufficient ethelene glycol in the bottom reservoir to create an ethelene glycolsaturated atmosphere. Samples were analysed by X-ray diffraction, within minutes of taking the samples from the bell jar.

Instrumentation -

(Dept. of Earth Sciences, Carleton Univ.) 
All diffractograms were made using a Philips PW 1050 diffractometer with a graphite monochromator, PW 1730 diffractometer generator and PW 1710 diffractometer control, operating at $40 \mathrm{kV} 40 \mathrm{~mA}$, using Ni-filtered $\mathrm{CuK} \propto$ radiation, a scanning speed of $3^{0} /$ minute, slits of $1^{0}-0.1 \mathrm{~mm}-1^{0}$, a chart speed of $1 \mathrm{~cm} /{ }^{0} 2 \Theta$, and a time constant of 2 .

\section{Illite Crystallinity}

Sample Preparation -

(Dept. of Earth Sciences, Carleton Univ.)

Oriented powder mounts on glass slides were prepared using the $<2 \mu \mathrm{m}$ fraction separated from each sample by the method outlined above. The illite crystallinity of each sample was determined by measuring the width of the $10 \AA$ mica peak from an X-ray diffractogram using a magnifying glass and a precision rule. The $5 \AA / 10 \AA$ peak intensity ratios were measured from the same diffractograms.

Instrumentation -

(Dept. of Earth Sciences, Carleton Univ.)

Same as X-Ray Diffractometry.

Infrared Spectroscopy. 


\section{Sample Preparation -}

(Centre for Land and Biological Resources Research, Agriculture Canada, Ottawa) Visible interstitial material was hand picked from each sample. The mineralogy of the picked material was then approximated using X-ray diffractometry. One mg of the same material was mixed with $400 \mathrm{mg} \mathrm{KBr}$. Sample pellets were made in a pellet press under vacuum and $15000 \mathrm{lbs}$ pressure, applied for 15 minutes.

Instrumentation -

(Centre for Land and Biological Resources Research, Agriculture Canada, Ottawa) Infrared spectra were generated using a Perkin Elmer 16F PC FT-IR spectrophotometer, linked to a computer. Spectra were recorded, under $\mathrm{N}_{2}$-saturated conditions, in the range 300 to $4000 \mathrm{~cm}^{-1}$, at a scanning speed of $300 \mathrm{~cm}^{-1} / \mathrm{min}$. Gain $=0.60$ to $0.72 ;$ period $=1$ second; slit width $=0.3 \mathrm{~mm}$ at $3000 \mathrm{~cm}^{-1}$.

\section{X-Ray Fluorescence.}

Sample Preparation -

(Geology Dept., Ottawa Univ., performed by Mr. R. Hartree)

Fused glass disks were made by heating $1.3 \mathrm{~g}$ of powdered rock sample with a flux of $3.9 \mathrm{~g}$ lithium tetraborate and $0.433 \mathrm{~g}$ of lithium carbonate.

Instrumentation -

(Geology Dept., Ottawa Univ., performed by Mr. R. Hartree) 
Major oxide and trace element analyses were carried out on a Philips PW 1410 automated X-ray fluorescence spectrometer. Sample discs were irradiated using a Cr X-ray tube. Data reduction was done on a PC by the method of De Jongh (1973). Accuracy was determined by duplicating analyses; precision was determined using the analyses of standards (Abbey (1983): syenite SY-2, diorite DR-N, gabbro MRG-1, granite GA and GS-N, rhyolite RGM-1).

Ferrous Iron Determination.

Methodology -

(Geology Dept., Ottawa University, performed by Mr. J. Loop)

The ferrous iron content of each sample was determined by a modified Wilson cold acid digestion method, using metavanadate titration, as described by Wipple (1974).

Stable Isotope Determination.

Methodology -

(Geological Survey of Canada, performed by Dr. B. Taylor)

For oxygen isotope $\left(\delta^{18} \mathrm{O}\right)$ analyses: following the technique of Clayton and Mayeda (1963), 10-12 mg of kaolinite was reacted with bromine pentafluoride, at $550^{\circ} \mathrm{C}$, to liberate oxygen from the sample. Liberated oxygen was then converted to carbon dioxide by reacting it with a carbon rod. The isotopic $\mathrm{O}^{18} / \mathrm{O}^{16}$ ratio of the resultant gas was then measured using a Finigan Mat 252 mass spectrometer. The 
data are reported using $\delta$-notation, relative to Vienna Standard Mean Ocean Water (V-SMOW): the precision of $\delta^{18} \mathrm{O}$ measurements is $+/-0.1 \% 0$ ).

For hydrogen isotope $(\delta \mathrm{D})$ analysis: $10-70 \mathrm{mg}$ of kaolinite was heated to $1100^{\circ} \mathrm{C}$ under a vacuum and the resultant water collected. Following the technique of Bigeleisen et al. (1952), the water was then reduced to hydrogen gas by reaction with metallic uranium heated to $750^{\circ} \mathrm{C}$. The isotopic $\mathrm{D} / \mathrm{H}$ ratio was determined using a mass spectrometer built from Nuclide comfonents. The data are reported using $\delta$-notation, relative to V-SMOW: the precision of $\delta$ D measuremen , is $+/ \cdot 1 \%$.

\section{Uranium Determination.}

Uranium in paleosol profile samples was analysed commercially by Atomic Energy of Canada Lid. using neutron activation and delayed neutron counting methodology (samples from Profiles 1 and 2), and by Bondar-Clegg and Company Ltd. using induced neutron actiation (Profile 3) and fluorometric titration (Profile 4).

\section{Inductively Coupled Argon Plasmal Analyses.}

Sample Preparation -

(Geology Depr., Onama Linis.. performed hy Mr. J. Loup and Q. Gall)

This sample preparation for ICP-AES analysis clusely follow that described by Crock and Lichte (1982). Approximately 0.5 g of sample was mixed with 2-3 g of lithium 
metaborate flux (Spectraflux 100A) in a graphite crucible. The crucible was fused in a muffle furnace at $1000^{\circ} \mathrm{C}$ for 20 minutes. The molten bead was poured into 50 $\mathrm{ml}$ beakers containing $1 \mathrm{~N} \mathrm{HCl}$ on a stirring plate. The solution was then loaded on a pre-equilibriated column containing 100-200 mesh DOWEV AG50W-X8 resin. Major and trace elements were eluted through the column with $100 \mathrm{ml} 2 \mathrm{~N} \mathrm{HCl}$. REE and $\mathrm{Y}$ content of the sample was eluted with $250 \mathrm{ml} 6 \mathrm{~N} \mathrm{HCl}$. The REE- and Y-bearing elution was then evaporated to dryness, and the residue redissolved with $15 \mathrm{ml} 1 \mathrm{~N} \mathrm{HNO}_{3}$.

\section{Instrumentation -}

(Geology Dept., Ottawa Univ., performed by Mr. J. Loop)

Plasma analyses were made using a Thermo Jarrell Ash ATOMSCAN 25 sequential scanning spectrometer. Precision, measured by analysing the standards SY2 and SY3 (Abbey, 1983), was generally better than $+/-7 \%$. Accuracy was determined by duplication of sample analysis, which indicated an accuracy of $+1-7 \%$ or better. The analytical wavelengths used for element quantification were as follows: $\mathrm{Y}=371.0$ $\mathrm{nm}, \mathrm{La}=408.6 \mathrm{~nm}, \mathrm{Ce}=418.6 \mathrm{~nm}, \mathrm{Pr}=422.5 \mathrm{~nm}, \mathrm{Nd}=430.3 \mathrm{~nm}, \mathrm{Sm}=442.4 \mathrm{~nm}$, $\mathrm{Eu}=381.9 \mathrm{~nm}, \mathrm{Gd}=342.2 \mathrm{~nm}, \mathrm{Dy}=353.1 \mathrm{~nm}, \mathrm{Ho}=345.6 \mathrm{~nm}, \mathrm{Er}=337.3 \mathrm{~nm}, \mathrm{Yb}=$ $328.9 \mathrm{~nm}, \mathrm{Lu}=261.5 \mathrm{~nm}$. 
Electron probe microanalyses.

Instrumentation -

(Dept. of Earth Sciences, Carleton Univ., performed by Mr. P. Jones and Q. Gall) Mineral analyses were determined by energy dispersive spectrometry or wavelength spectrometry using a Cambridge Microscan 5 electron probe microanalyser. Operating conditions were set at $20 \mathrm{kV}$ acceleration potential and a specimen current of 9.0 nanoamperes. Data reduction was done on a PC using the EDDI program of Pringle (1989). Standard minerals used were: Durango apatite USNM 104021 (for apatite) and kyanite (for kaolinite).

Scanning electron microscope - energy dispersive analyses. Instrumentation -

(Dept. of Earth Sciences, Carleton Univ., performed by Mr. P. Jones)

APS mineral composition was determined using polished thin sections in a JEOL JSM 6400 scanning electron microscope coupled to a Link System Ltd. eXL LZ4 Xray analyser. The SEM was operating at $20 \mathrm{kV}$ acceleration voltage. Microbeam analyses used a $0.2 \mathrm{nA}$ beam current, a take-off angle of $40^{\circ}$ for the Link detector, and 100 to 150 second counting time. Matrix correction was made with Link ZAF4/FLS. Element standards were as follows: Ca- wollastonite, Sr- syn. $\mathrm{SrTiO}_{3}$, Ba- barite, La- syn. $\mathrm{LaAlO}_{3}, \mathrm{Ce}$ - syn. $\mathrm{CeO}_{2}$, Pr-syn. $\mathrm{PrF}_{3}$, Nd- syn. $\mathrm{NdAlO}_{3}$, Th- syn. $\mathrm{ThO}_{2}, \mathrm{Al}-\mathrm{Al}_{2} \mathrm{O}_{3}, \mathrm{Fe}-\mathrm{Fe}_{2} \mathrm{O}_{3}, \mathrm{P}-\mathrm{NaBePO}_{4}, \mathrm{~S}-\mathrm{FeS}_{2}$. 


\section{REFERENCES}

Abbey, S. 1983. Studies in "standard samples" of silicate rock and minerals 1969-1982.
Geological Survey of Canada, Paper 83-15, 114 p.

Bigeleisen, J., Pearlman, M.L. and Prosser, H.C. 1952. Conversion of hydrogenic materials to hydrogen for isotopic analysis. Analytical Chemistry, v. 24, pp. 1356-1357.

Clayton, R.N. and Mayeda, T.K. 1963. The use of bromine pentafluoride in the extraction of oxygen from oxides and silicates for isotopic analysis. Geochimica et Cosmochimica Acta, v. 27, pp. 43-52.

Crock, J.G. and Lichte, F.E. 1982. Determination of rare earth elements in geological materials by inductively coupled argon plasma-atomic emission spectrometry. Analytical Chemistry, v. 54, pp. 1329-1332.

De Jongh, W.K. 1973. X-ray fluorescence analysis applying theoretical matrix correction. Stainless steel. X-Ray Spectrometry, v. 2, pp. 151-158.

Pringle, G.J. 1989. EDDI - A FORTRAN computer program to produce corrected microprobe analyses of minerals using an energy dispersive X-ray spectrometer. Geological Survey of Canada, Open File 2127. 
Wipple, ER, 1974. A study Cof Wilson's determination of ferrous iron silicates. Chemical Geology, v. 14, pp. 223-238. 
APPENDIX II

\section{ADDITIONAL ANALYSES}


During the summer of 1990, geological mapping north and west of Dubawnt Lake for the Geological Survey of Canada (Peterson, 1992), provided an opportunity to obtain additional samples of weathered and unweathered Archean megacrystic granite and leucogranite. The megacrystic granite and leucogranite are considered to be comagmatic (Peterson et al., 1989) and can only be distinguished by texture. The samples were analysed using the same techniques that were used to analyse samples from the four paleoweathering profiles; the results are presented in Table AII.1. These additional samples (a) further demonstrate the effect that paleoweathering has had on element mobility, (b) allow comparison with the element trends described for Profile 2, which also has a megacrystic granite protolith, and (c) the megacrystic granite serves as a check on the element trends seen in Profile 2. That is, they demonstrate whether the element abundances in the paleosol samples actually fall within the natural variability of the unweathered megacrystic granite.

In Table AII.1, compared to the unweathered magacrystic granite samples, the weathered granite samples show a relative increase in $\mathrm{SiO}_{2}, \mathrm{Fe}_{2} \mathrm{O}_{3}$ and $\mathrm{CIA}$, and a relative decrease in $\mathrm{Al}_{2} \mathrm{O}_{3}$ (minor), $\mathrm{FeO}, \mathrm{MnO}$ (minor), $\mathrm{MgO}, \mathrm{CaO}, \mathrm{Na}_{2} \mathrm{O}, \mathrm{K}_{2} \mathrm{O}, \mathrm{Rb}$, $\mathrm{Sr}$ and $\mathrm{Ba}$. For the leucogranite, despite the paucity of samples for comparison, the weathered samples are noticeably enriched in $\mathrm{Fe}_{2} \mathrm{O}_{3}, \mathrm{P}_{2} \mathrm{O}_{5}$ and $\mathrm{Sr}$, and have higher CIA values, compared to the unweathered samples.

These changes are similar to those seen in the paleoweathering profiles 
generally, and Profile 2 in particular. Apart from iron oxidation, paleoweathering appears to have been responsible for a depletion of many elements, as indicated by very high CIA values for the weathered samples. The increase in $\mathrm{P}_{2} \mathrm{O}_{5}$ and $\mathrm{Sr}$ in the weathered lecogranite samples can be related to the presence of the APS mineral in some samples. The APS mineral can be seen in thin sections of the same samples.

Comparing analyses for the two paleosol samples in Profile 2 (Samples 5 and 4, Table 2.1.1) with the average and standard deviation for unweathered megacrystic granite analyses (Table AII.1); it is apparent that the amount of $\mathrm{SiO}_{2}, \mathrm{TiO}_{2}, \mathrm{Al}_{2} \mathrm{O}_{3}$, $\mathrm{MgO}, \mathrm{P}_{2} \mathrm{O}_{5}, \mathrm{Cr}, \mathrm{Zr}$ and $\mathrm{Rb}$ in the paleoweathered samples falls within the natural variability in element abundance of the unweathered megacrystic granite. Conversely, in the paleoweathered samples, total iron and $\mathrm{Fe}_{2} \mathrm{O}_{3}$ abundances and $\mathrm{CIA}$ trends are greater, and $\mathrm{FeO}, \mathrm{MnO}, \mathrm{CaO}, \mathrm{Na}_{2} \mathrm{O}, \mathrm{K}_{2} \mathrm{O}, \mathrm{Sr}$ and $\mathrm{Ba}$ abundances are less, than the natural variability of the unweathered megacrystic granites. Thus, despite the small number of analyses, paleoweathering of the megacrystic granite is inferred to have led to the relative depletion of many elements, and to an increase in $\mathrm{Fe}_{2} \mathrm{O}_{3}$ and CIA. 


\section{REFERENCES}

Peterson, T.D. 1992. Geology, Dubawnt Lake area, District of Keewatin, Northwest Territories. Geological Survey of Canada, Open File 2551, (map) scale 1:100 000.

Peterson, T.D., LeCheminant, A.N., and Rainbird, R.H. 1989. Preliminary report on the geology of northwestern Dubawnt Lake area, District of Keewatin, N.W.T. Geological Survey of Canada, Paper 89-1C, pp. 173-183. 


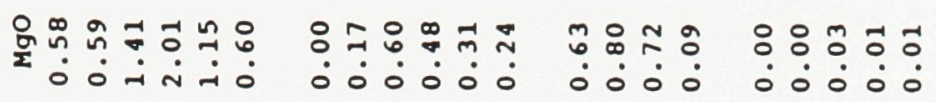

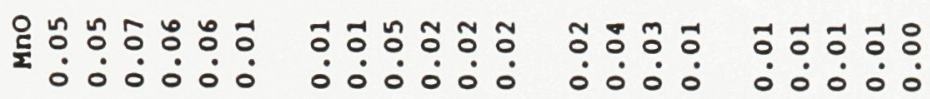

さ્స

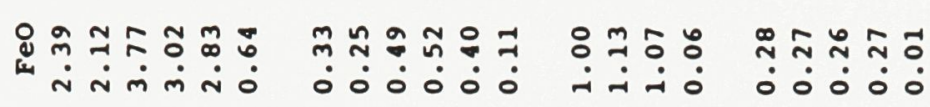

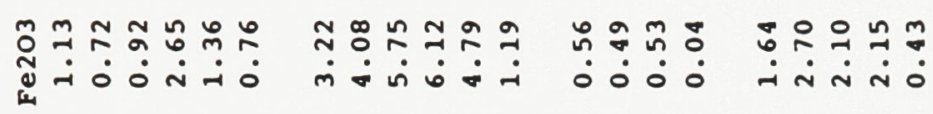

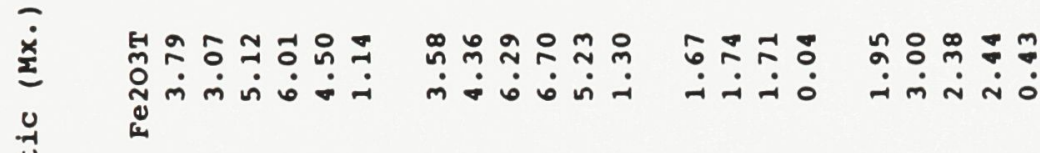

\section{西}

-

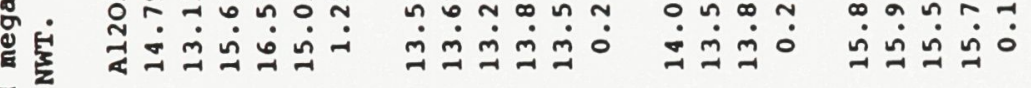

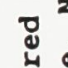
离的

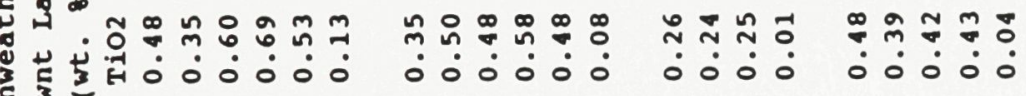
亭

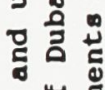

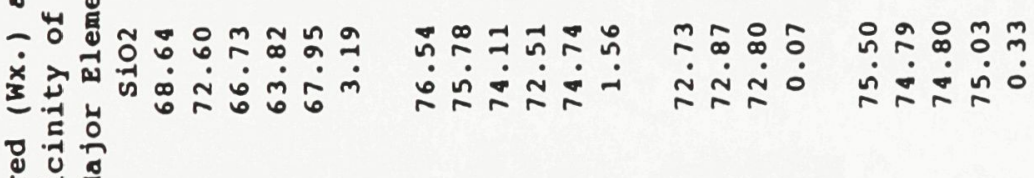
过 


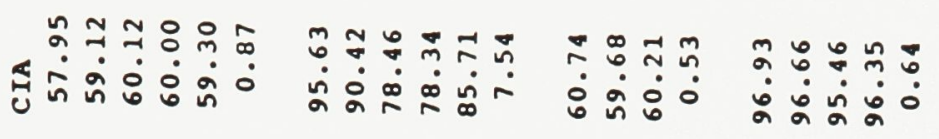

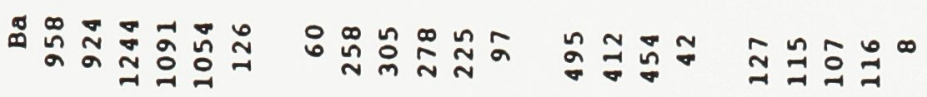

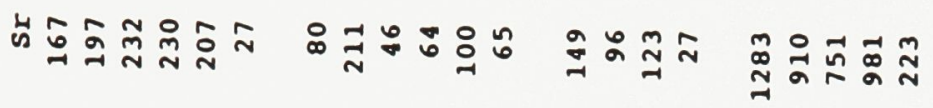

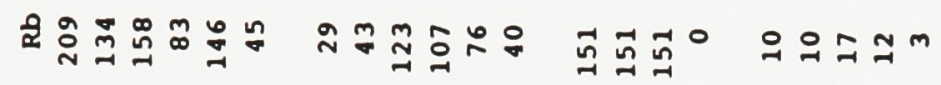

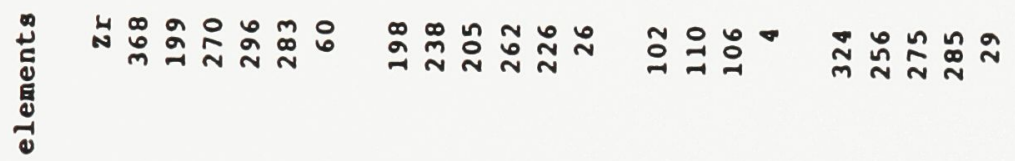

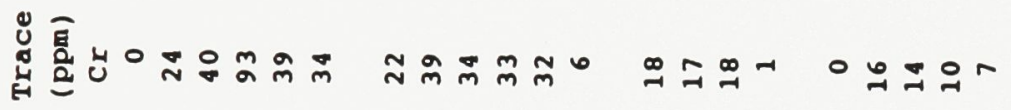

苜

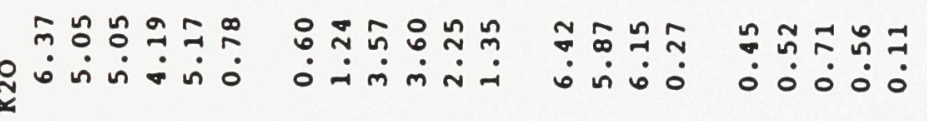

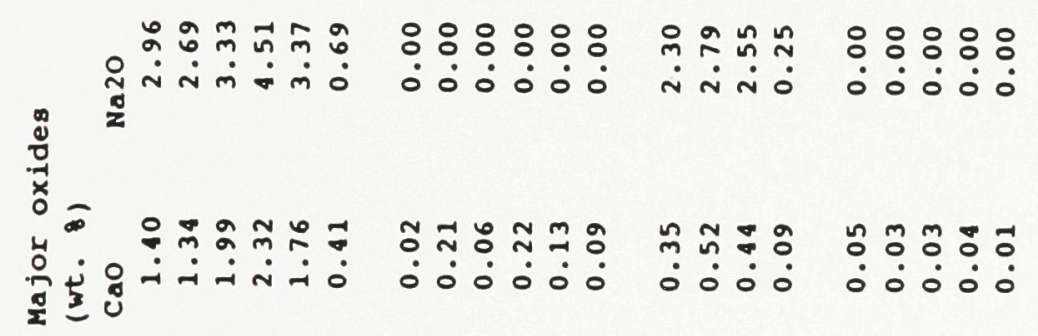

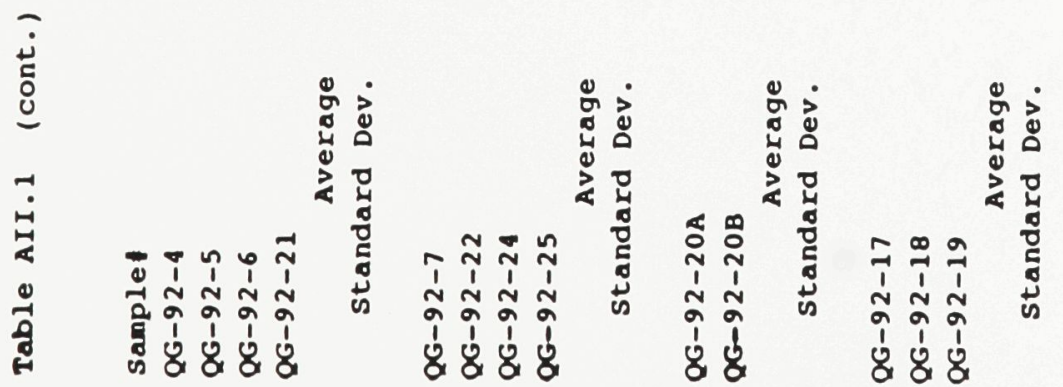

